\title{
Economic and Monetary Union Governance at Risk: The Asymmetric Application of Europe's Stability and Growth Pact
}

by

\author{
Bartholomew Paudyn
}

\begin{abstract}
A thesis submitted to the
Faculty of Graduate Studies and Research in partial fulfillment

of the requirements for the degree of

Doctor of Philosophy
\end{abstract}

Department of Political Science

Carleton University

Ottawa, Ontario

Canada

(C) 2010 Bartholomew Paudyn

Reproduced with permission of the copyright owner. Further reproduction prohibited without permission. 


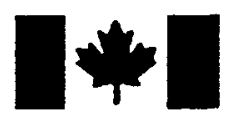

\author{
Library and Archives \\ Canada \\ Published Heritage \\ Branch \\ 395 Wellington Street \\ Ottawa ON K1A ON4 \\ Canada
}

Bibliotheque et

Archives Canada

Direction du

Patrimoine de l'édition

395 , rue Wellington

Ottawa ON K1A ON4

Canada
Your file Votre reference

ISBN: 978-0-494-67900-5

Our file Notre reférence

ISBN: 978-0-494-67900-5
NOTICE:

The author has granted a nonexclusive license allowing Library and Archives Canada to reproduce, publish, archive, preserve, conserve, communicate to the public by telecommunication or on the Internet, loan, distribute and sell theses worldwide, for commercial or noncommercial purposes, in microform, paper, electronic and/or any other formats.

The author retains copyright ownership and moral rights in this thesis. Neither the thesis nor substantial extracts from it may be printed or otherwise reproduced without the author's permission.
AVIS:

L'auteur a accordé une licence non exclusive permettant à la Bibliothèque et Archives Canada de reproduire, publier, archiver, sauvegarder, conserver, transmettre au public par télécommunication ou par l'Internet, prêter, distribuer et vendre des thèses partout dans le monde, à des fins commerciales ou autres, sur support microforme, papier, électronique et/ou autres formats.

L'auteur conserve la propriété du droit d'auteur et des droits moraux qui protège cette thèse. $\mathrm{Ni}$ la thèse ni des extraits substantiels de celle-ci ne doivent être imprimés ou autrement reproduits sans son autorisation.
In compliance with the Canadian Privacy Act some supporting forms may have been removed from this thesis.

While these forms may be included in the document page count, their removal does not represent any loss of content from the thesis.
Conformément à la loi canadienne sur la protection de la vie privée, quelques formulaires secondaires ont été enlevés de cette thèse.

Bien que ces formulaires aient inclus dans la pagination, il n'y aura aucun contenu manquant.

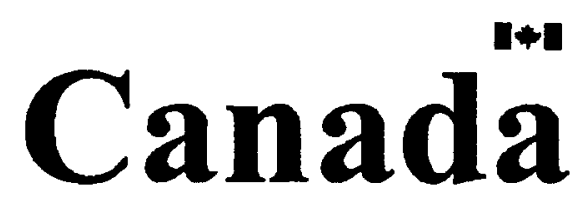




\begin{abstract}
$\underline{\text { Abstract }}$
This dissertation focuses on the political economy of Europe's Economic and Monetary Union (EMU) in the aftermath of one of its most severe debacles; namely the Economic and Financial Affairs Council (Ecofin) crisis of 2003. In late November, Germany and France orchestrated a blocking coalition in Ecofin, essentially undermining the entire fiscal framework, the Stability and Growth Pact (SGP). A shock of this magnitude preempted the contestation of previously immune risk technologies, opening up new spaces for rethinking how calculative forms of government are deployed within EMU. Although not a rigid binary opposition, this may be conceptualised as a dialectic between risk and uncertainty, which is encapsulated in the relationship between expertise and politics. Thus, how is expertise being transformed in the aftermath of the asymmetric application of SGP and what are the ramifications for the regulatory design of EMU?

I employ a "governmentality" framework to problematise the reorgansiation of fiscal management from a system predominantly governed through risk to one regulated through uncertainty. Through a critical genealogy, I ascertain what kind of economy of power Europe is implicated in and what this means for governance within and beyond European borders. This involves diagramming the government of uncertainty in a decentred manner in order to trace how power operates through specific discourses (e.g. new monetarism) and practices (e.g. Medium-Term Budgetary Objective) to produce the stabilisation recognised as EMU. In the process, we arrive at a re-imaged spatial-temporal explanation of governance to adequately capture how the political economy of EMU comes to exist through the diffuse technologies through which control happens.
\end{abstract}


As a governmental artefact, EMU incorporates various discursive practices in its construction of new geographies of power and notions of responsibility. A genealogical approach allows us to determine how they condition representations of normalcy, underpinning responsibility, and how the practice of surveillance as regulation, embedded within the political economy of EMU, has changed since the introduction of the 2005 SGP reforms. By internalising notions of normalcy negotiated to accommodate their unique contingencies, states are more amenable to accept responsibility for their fiscal conduct. As a new analytical instrumentality, governmentality directs our attention to how this novel set of discursive practices helps constitute conceptions of normalcy, as anchors for fiscal relations, in this emerging fiscal-monetary space. Uncertainty is a modality of government that informs this transition towards the (re)politicisation of fiscal relations across Europe. 


\section{Acknowledgements}

I wish to express my heartfelt gratitude to a group of individuals who have each contributed their guidance and support to help make this dissertation possible. First of all, I am especially grateful to my supervisor, Randall Germain, for the enthusiasm and tutelage that he has provided throughout the course of this project. His engagement and inspiration have challenged me to refine my ideas, while making my academic advancement that much more enjoyable. I am also indebted to my committee members. William Walters has skilfully channelled my interests in critical social theory to help me grapple with some of the monetary and fiscal politics which I analyse. Achim Hurrelmann has wisely counselled me on the operations of the European Union, while reminding me of the future implications of my research. Many thanks to Aaron Doyle and Pat O'Malley for their constructive criticisms, which alerted me to the value-added of risk and uncertainty.

Part of this project was funded by the Social Sciences and Humanities Research Council of Canada under the "Strategic Knowledge Cluster Program." It granted me the opportunity to consult with Amy Verdun at the University of Victoria. Her immense knowledge of European political economy has proven highly advantageous, especially in the final stages of my dissertation. The Cluster has also contacted me with numerous academics and policy-makers, in the field of EU studies, who helped crystallise my arguments. Their assistance is sincerely appreciated.

I owe my greatest debt to my family. My parents, Jack and Barbara Paudyn, have nurtured my passions and ambitions with their unconditional love and support. Gabriel Paudyn, my brother, has reminded me of how significant balance is to happiness. Together, they have helped me more than I'll ever know. 


\section{Contents}

$\begin{array}{ll}\text { Abstract } & \text { ii }\end{array}$

Acknowledgements iv

Contents

List of Acronyms \&Abbreviations vii

1. Introduction: Reframing the EMU Problematic through Uncertainty 1

$\begin{array}{ll}\text { 1.1 Fiscal Framework Fiasco } & 15\end{array}$

1.2 A Trinity of Inconsistencies 20

1.3 The Discretionary Response of 2005

1.4 Governmentality and Uncertain Trajectories 31

1.5 Problematising Organizational Management- Plan of Dissertation 36

2 Theoretical Deficits: Dated Categories and Methods 46

2.1 Problematic Conceptualisations (pun intended) 52

Liberal Intergovernmentalism: The Normative and Prescriptive 54

Liberal Intergovernmentalism: The Critique 66

Constructivism: The Normative and Prescriptive 78

Constructivism: The Critique $\quad 91$

Critical Political Economy: The Normative and Prescriptive $\quad 100$

Critical Political Economy: The Critique 112

2.2 Certainly Not the Last Word $\quad 120$

3 Analytics of Government 122

3.1 The Deconstructive Analytics of Managing EMU $\quad 130$

Truth Techniques 131

Technologies of Power 134

Mentalities of Rule 138

3.2 Reconstructing the Fiscal-Monetary Space $\quad 140$

Performativity 141

Critical Ontology of Normalcy 147

Spatial-Temporal Coordinates 149

3.3 Risk and Uncertainty as Modes of Governance 153

Risk Operational: The Analytical and Conditional 156

Risk Operational: The Operational Migration 162

- Internal Control 166

- Operational Risk 172

- Reputational Risk 175 


\section{Contents}

Uncertainty: The Analytical and Conditional 180

Uncertainty: Operational Dynamics 188

- Uncertainty Surrounding Internal Control 191

- Operational Uncertainty 194

- Reputational Uncertainty 197

3.4 Tracing Uncertainty through the Stability and Growth Pact 200

4 “Lisbonising” the Stability and Growth Pact 204

4.1 Amending the Rationality of the Pact 211

Taking Stock of "Good Times" 217

4.2 The Preventative Arm: Technologies of Rule 232

Country Specific Medium-Term Budgetary Objectives 239

Medium-Term Budgetary Review $\quad 249$

4.3 The Corrective Arm: Technologies of Rule 259

Excessive Deficit Procedure $\quad 265$

$\begin{array}{ll}\text { 4.4 Retracing the Terrain of Government } & 277\end{array}$

5 Contesting the Template of Normalcy 281

5.1 Variations of Normalcy 284

5.2 Performative Generations 290

5.3 Global Resonance 295

6. Conclusion: Into the Great Wide Open 300

6.1 Rethinking Fiscal Governance $\quad 302$

6.2 Theoretical and Empirical Resonance 310

$\begin{array}{ll}\text { Bibliography } & 319\end{array}$ 


\section{List of Acronyms \&Abbreviations}

$\begin{array}{ll}\text { BEPG } & \text { Broad Economic Policy Guidelines } \\ \text { CDSS } & \text { Credit-Default Swaps } \\ \text { CPE } & \text { Critical Political Economy } \\ \text { CTBOIS } & \text { Close-to-balance or in surplus } \\ \text { DJIA } & \text { Dow Jones Industrial Average } \\ \text { ECA } & \text { European Court of Auditors } \\ \text { ECB } & \text { European Central Bank } \\ \text { ECJ } & \text { European Court of Justice } \\ \text { EERP } & \text { European Economic Recovery Plan } \\ \text { Ecofin } & \text { Economic and Financial Affairs Council } \\ \text { ESCB } & \text { European System of Central Banks } \\ \text { EDP } & \text { Excessive Deficit Procedure } \\ \text { EFC } & \text { Economic and Financial Committee } \\ \text { EMU } & \text { European Monetary Union } \\ \text { EPC } & \text { Economic Policy Committee } \\ \text { ERM } & \text { Enterprise Risk Management } \\ \text { ERM II } & \text { Exchange Rate Mechanism } \\ \text { ERT } & \text { European Round Table of Industrialists } \\ \text { EU } & \text { European Union } \\ \text { GDP } & \text { Gross Domestic Product } \\ \text { IFI } & \text { International Financial Institutions } \\ \text { IG } & \text { Liberal Intergovernmentalism } \\ \text { ICT } & \text { Information and Communication Technology } \\ \text { MTO } & \text { Medium-Term Budgetary Objectives } \\ \text { MTBR } & \text { Medium-Term Budgetary Review } \\ \text { MTEF } & \text { Medium-Term Expenditure Frameworks } \\ \text { NRP } & \text { National Reform Programmes } \\ \text { NCB } & \text { National Central Banks } \\ \text { OMC } & \text { Open Method of Coordination } \\ \text { PBB } & \text { Performance-Based Budgeting } \\ \text { PIIGS } & \text { Portugal, Italy, Ireland, Greece, Spain } \\ \text { SAI } & \text { Supreme Audit Institutions } \\ \text { SCP } & \text { Stability and Convergence Programmes } \\ \text { SEPA } & \text { Single Euro Payment Area } \\ \text { SGP } & \text { Stability and Growth Pact } \\ \text { SV } & \text { Shareholder Value } \\ \text { SVAR } & \text { Structural Vector Autoregression models } \\ \text { SWPR } & \text { Schumpeterian Workfare Post-National Regime } \\ \text { TEC } & \text { Treaty Establishing the European Community } \\ \text { VaR } & \text { Value-at-Risk } \\ & \end{array}$




\section{Chapter 1 Introduction}

\section{Reframing the EMU Problematic through Uncertainty}

Much of the International Relations (IR) literature privileges a separation between politics and economics. ${ }^{1}$ Nowhere is this dichotomy more visible than in the areas of monetary and fiscal relations. Here the economic domain is often treated as an unproblematic and incontestable reality. The politics of representation and practices of discourse are virtually ignored, simply reinforcing a fictitious dualism between the ideal and the material. However, recent events in European integration have questioned the utility of such an approach. Once considered outside the realm of "politics," economic governance has become increasingly susceptible to political interference in the European Union (EU). This poses substantial challenges to the euro area making it vulnerable to destabilizing forces as its major economies seem unable to meet their budgetary obligations. To coordinate monetary and fiscal policies in the Economic and Monetary Union (EMU) with a federal European Central Bank (ECB), but no supranational fiscal authority, the EU devised a scheme to enforce budgetary discipline called the Stability and Growth Pact (SGP). By November 2003, two leading countries, France and Germany, abandoned the rules and thereby caused a major crisis of EMU, and a need to re-evaluate its regulatory foundations.

EMU has been beset with problems right from its introduction on January 1, 1999, when Europe witnessed the irrevocable locking of the conversion rates of eleven national currencies as they became denominations of the euro. This transition to "Stage Three" of EMU embodied the vision of Europe as an emerging, major player in international

\footnotetext{
${ }^{1}$ Robert Gilpin, The Political Economy of International Relations (Princeton: Princeton University Press, 1987); Mark Laffey, "Locating Identity: Performativity, Foreign Policy and State Action," Review of International Studies 26, no. 3 (2000): 429-44.
} 
economic and monetary affairs. ${ }^{2}$ By January 2001 , Greece had satisfied the convergence criteria and the last remnants of national legal tender disappeared. ${ }^{3}$ Without doubt, the EU represents one of the largest public sector configurations in which a panoply of regional and national administrative cultures and institutions function, often overlapping, to create a novel regulatory space. Yet what is glaringly absent is a comprehensive fiscal management and internal control system to adequately guarantee that public funds are soundly expended. Without such mechanisms in place, power politics began to intervene in what was traditionally considered outside its sphere of influence and affect the status of economic expertise. Pressures mounted, which ultimately proved irreconcilable within the confines of the original SGP, thereby precipitating the severe crisis of November 2003.

Doomed to fail because of its overly rigid structure, the SGP was perceived as artificially uniform. Punitive measures were never seriously entertained, especially since most countries failed to meet the convergence criteria upon adopting the euro. ${ }^{4}$ Defections resulting in Pareto-inferior equilibria were not overcome by the threat of sanctions. All these factors amplified the politics of risk and uncertainty associated with fiscal management to create new tensions. To amend the negative externalities produced by the SGP crisis, the architects of EMU, namely the Council with the Commission, introduced a more flexible and discretionary regulatory framework in March 2005. This marked a transition to uncertainty-centred modes of governance and signalled the "Lisbonisation," or (re)politicisation, of budgetary governance and expertise in Europe. In light of these

\footnotetext{
${ }^{2}$ Kenneth Dyson, The Politics of the Euro-Zone (New York: Oxford University Press, 2000); Amy Verdun, ed., The Euro: European Integration Theory and Economic and Monetary Union (Lanham, Md.: Rowman \& Littlefield Publishers, 2002).

${ }^{3}$ Slovenia would adopt the euro on January 1, 2007; Cyprus and Malta would follow suit on January 1, 2008; Slovakia joined the euro area on January 1, 2009.

${ }^{4}$ Philip Arestis and Malcolm Sawyer, "Macroeconomic Policy and the European Constitution," in Alternative Perspectives on Economic Policies in the European Union, ed. Philip Arestis and Malcolm Sawyer (New York: Palgrave MacMillan, 2006), 57.
} 
circumstances, how does the collapse of the SGP and the reforms which it engendered problematise European economic and monetary integration? Moreover, what is the affect on European political economy? It is this problematic that I wish to explore in the course of this dissertation. Meaning and materiality must be studied together. My intention is to reveal how the revised Pact signals an alternative mode of representing and managing the problem of fiscal affairs in EMU. Doing so will provide an enhanced and more comprehensive understanding of how power politics shapes, and is in turn influenced, by monetary and fiscal relations in the construction of one of the world's most ambitious politico-economic enterprises.

With the gruelling process of reform barely over and Europe battered by the global credit crisis and a recession that still plagues many countries, EMU must now prepare to welcome the remaining new Member States from Central and Eastern Europe into the euro area who have yet to adopt the common currency. Not only are there major uncertainties facing these new Member States in their struggles as developing economies, but many questions regarding their ability to meet the conditions for entry into the eurozone remain unanswered. The uncertainty of when and how these new countries will adopt the euro and the potential consequences of this transition are only compounded by the effects of the recent credit crisis; Latvia being the most glaring misfit. Current members are also in a precarious situation given their deteriorated public finances. Moreover, the entire process rests on a new regulatory regime that has yet to be proven effective to withstand the dangers of unleashed political forces. Under these conditions, the risks are immense and the future highly uncertain. 
In direct contrast to the centralised monetary domain, where the ECB sets a common monetary policy for the entire euro area, there is no equivalent supranational economic authority that oversees budgetary conduct. Rather the fiscal landscape of EMU is a fragmented collection of national policies. This heterogeneity complicates the task of locating and coordinating the appropriate mix of economic and monetary policies. Without recourse to individually tailored interest rates that correspond to their unique business cycles, Member States are nevertheless obligated to adhere to the fiscal framework underpinning EMU; namely the SGP. This is the political protocol which stipulates the deficit and debt ceilings of 3 percent to Gross Domestic Product (GDP) and 60 percent to GDP respectively. Or at least that is the ambition. Such ambitions, however, must be carefully located in what is arguably the increasingly politicised construction of a novel economic space.

Outside the auspices of the traditional nation-state and with its own set of articulations and practices of governance and valuation, the eurozone involves a new "monetization of time-space, rendering the future calculable... and presupposes a particular rationalization of money and risk." ${ }^{5}$ Unfortunately, EMU rationalities and practices are not always compatible with national needs and interests. As such, a host of technical and political interventions, such as the SGP, have been designed in the attempt to reconcile the policy conflict resulting from an opaque underlying model, which assigns different mandates to Member States (output stabilisation) and to the ECB (price stability). Yet, what is right for one state may be detrimental to the economic position of its neighbour and/or the broader EMU. This is the hazard implicit in the asymmetric configuration and

\footnotetext{
${ }^{5}$ Michael Pryke and John Allen, "Monetized Time-Space: Derivative-Money's 'New Imaginary,"” Economy and Society 29, no. 2 (May 2000): 264-84.
} 
operation of EMU. How we come to understand this conundrum, and EMU governance more generally, is increasingly framed in reference to the potential threat from particular future liabilities or uncertainties, such as those of fiscal profligacy. Contingency has become central in how officials account for the variety of dangers facing the eurozone stemming from fiscal conduct and how it informs their attempts to mitigate these liabilities.

Whereas risk is defined as an aggregable and probabilistically quantifiable frequency of an undesirable event, uncertainty may be understood as a subjective estimation, as the "fluid art of the possible." Uncertainty implies that possible outcomes may be identified but cannot be assigned a probability distribution denoting their success given their unique circumstance. Greater reliance is thus placed on non-quantitative techniques, such as seasoned judgement and rules of thumb, to calculate available prospects and decide what constitutes the best policy response. Uncertainty includes risk but not vice-versa. Theirs is a dialectical rather than a binary relationship. Both are governmental constructs that help interpret the various challenges confronting public policy though calculative frames. Thus, the problem of EMU governance is understood as an estimation of some indeterminate future. This knowledge then informs how the policies and programmes that constitute this novel fiscal-monetary space we call EMU are devised and deployed. With the 2005 SGP reform, risk practices are being revaluated and reconfigured into novel governmental arrangements, along with uncertainty, in the effort to address and ameliorate a litany of inconsistencies plaguing this fiscal-monetary plane. Increasingly, there is a visible shift towards a new style of uncertainty-based modes of governance. How this movement impacts European political economy is the puzzle at the heart of this dissertation.

\footnotetext{
${ }^{6}$ Pat O'Malley, Risk, Uncertainty and Government (Portland: The Glasshouse Press, 2004), 5.
} 
Orchestrated through the deployment of a new set of discourses and technologies of uncertainty, the movement in the reorganization of this emerging spatial-temporal order is codified in the reformed Pact. New regulatory spaces are opening up questioning risk's dominance as a governmental construct as the problem of fiscal management is reframed along vectors of uncertainty. Uncertainty involves mobilizing the perception of contingency implicit in fiscal relations rather than an "objective" effect or an underlying reality of some sort. As an invention of government, it is helping engineer a novel "leverage" of control, or an authoritative capacity, designed to modulate the fiscal conduct of Member States according to variegated notions of "normalcy."

Rather than subscribing to a single notion of normalcy, as was the case with the "close-to-balance or in surplus" (CTBOIS) requirement, the new Pact reaffirms that there is no one acceptable, universal definition of a normal fiscal standard. EMU is the site of contestation where competing visions of normality are articulated. These considerations inform how states define their national interests. To prevent failure, differentiated appraisals are necessary to accommodate this diversity and variability among Member States. Subsequently, this affects how responsibility is reconceptualised and legitimated in EMU. The ambition is to induce the internalisation of self-regulation among Member States to respect the statutes. This must be located within a broader discursive field in which fiscal profligacy is represented as a particular problem of government and translated into the appropriate regulatory regime to deal with such challenges. Uncertainty informs this process.

Under a governmental modality of uncertainty, self-regulating tendencies that foster compliance are optimised whereas malignant behaviour is minimised. Through the 
internalisation of self-regulation, members are envisioned as enterprising subjects entrusted with the responsibility of prudently managing their fiscal books. This leverage is an indirect mechanism of authority that is exerted by the organisational apparatus, which works to modulate EMU subjects into compliance. Adapted from Bruno Latour's notion of "actionat-a-distance," this modality of rule facilitates the "translation" of diverse problematisations into mutually corresponding, and potentially reinforcing, ones. ${ }^{7}$ Through this authoritative capacity, networks of similar-minded actors form, as in the case of EMU. Uncertainty reinscribes the spatial-temporal dimension of this formula by further distancing actors from formal sources of authority as they are obliged to utilise their own "self-conscious critical faculties" in managing an indeterminate future. ${ }^{8}$ Creative entrepreneurialism is assigned more value in these assemblages as the Commission and the Council strive to devise the best strategies to reconcile long-term sustainability with the expansionary policies intended to spur economic growth. Forms of control are most evident here.

Arguably, the governing exercise becomes more endogenous even though riskcentred techniques are not displaced but rather reconfigured. The government through uncertainty introduces this novel form of leverage into European fiscal relations. Although the 2005 reforms provide what appears to be a less intrusive and rigid framework, politicians and governments are now confronted with the more endogenous responsibility of managing their own uncertainty. This contrasts with risk-centred formulas of rule which are arguably more exogenous of agency given their preoccupation with supposedly objective and quantifiable knowledge. Quite often, this tendency to accept numerical

\footnotetext{
${ }^{7}$ Bruno Latour, Science in Action (Milton Keynes: Open University Press, 1987).

${ }^{8}$ Douglas R. Holmes and George E. Marcus, "Cultures of Expertise and the Management of Globalization," in Global Assemblages: Technology, Politics, and Ethics as Anthropological Problems, ed. Aihwa Ong and Stephen J. Collier (Malden, MA: Blackwell Publishing, 2005), 237.
} 
figures as demarcating the boundary between truth and fiction fails to problematise their legitimacy. Certainty equivalence is taken for granted given that risk management is presented as a defendable process. In effect, this managerial predisposition immunises policy-makers from shouldering some the burden of responsibility for their decisions since risk technologies provide a buffered form of rule. Essentially, with risk, the decisionmaking process is external to the actor while with uncertainty it is highly subjective and internal. Locating responsibility varies for this reason.

With this in mind, my intention is to problematise European fiscal governance in light of the SGP crisis and the March 2005 reforms it engendered. Few would dispute the penetration and resonance of risk as a category and method of organising relations in a vast array of areas and disciplines. ${ }^{9}$ If, arguably, risk is not as salient as a governmental construct in the management of fiscal relations, then we must ask ourselves three questions. First, how does the differentiated assessment of SGP statutes problematise European economic management? Specifically, how are risk and uncertainty transformed into dominant "modes of governance?" A mode of governance may be conceptualised as a managerial approach with a programmatic character that aligns a political rationality with the interventionary practices that allow it to modulate conduct. How we come to know an object determines the regulatory apparatus which is devised to govern it. If, as Miller and Rose remind us, "political rationalities render reality into the domain of thought" then “"technologies of government' seek to translate thought into the domain of reality" in order

\footnotetext{
${ }^{9}$ Niklas Luhmann, Risk: A Sociological Theory (Berlin: de Gruyter, 1993); Ulrich Beck, World Risk Society (London: Polity, 1999); Michael Power, The Risk Management of Everything (London: Demos, 2004).
} 
to act upon objects (original italics). ${ }^{10}$ Thus, modalities of rule have both a discursive and technological dimension to them.

I submit that power politics, reinforced by the Lisbon Treaty, has amplified the antagonisms implicit in the original Pact revealing particular conceptual, ideological, and institutional inconsistencies, which culminated in its eventual crisis. This (re)politicisation of fiscal relations reintroduces neo-Keynesian demand management strategies into an essentially monetarist creation. Subsequently, this discursive shift has compelled the architects of EMU to understand the problematic through an analytical framework increasingly rooted in the language and ideas of uncertainty. New forms of uncertainty government, such as the Medium-Term Budgetary Review (MTBR), are devised to accommodate the tensions that result. Yet, the interesting observation is not that there is more uncertainty or risk. Rather it is how uncertainty moderates the politics of representation associated with the problem of fiscal profligacy and how these perceptions are mobilised in the form of a new regulatory apparatus which seeks to discipline EMU subjects into compliance.

Second, what is the regulatory capacity through which risk and uncertainty, as modes of governance, are delivered? How do the architects of EMU address the changing problems associated with fiscal profligacy through specific programmes? EMU is rendered "real" by this regulatory governance capacity composed of the discourses and mechanisms designed to handle the increasing extensity and intensity of fiscal and monetary conduct across Europe. It calls for a re-imaged spatial-temporal explanation of governance to adequately capture how the political economy of EMU comes to exist through the diffuse technologies whereby leverage is exerted to control conduct. This dissertation endeavours

\footnotetext{
${ }^{10}$ Peter Miller and Nikolas Rose, "Governing Economic Life," Economy and Society 19, no. 1 (1990): 8.
} 
to draw up a critical genealogy tracing the various discourses and technologies deployed to minimise the dangers facing EMU, which contribute to the government through uncertainty in the post-2003 environment.

As a governmental artefact, EMU incorporates various discursive practices in its construction of new geographies of power and notions of responsibility. A genealogical approach allows us to ascertain how notions of normalcy, underpinning responsibility, are constituted and how the practice of surveillance as regulation embedded within the political economy of EMU changed since 2005. Judged against pre-established reference values (initially biased towards deficits rather than debt), power is exercised through constant monitoring. To be effective, surveillance must be more amenable to diverse, national political developments in the enforcement of the Pact. Lacking a uniform standard, the vulnerability of risk's dominance in defining and managing EMU subjects and practices is exposed. Whereas most IR theories of European integration take risk to be self-evident, my genealogy renders "visible a singularity at places where there is a temptation to invoke a historical constant...or an obviousness which imposes itself uniformly on all (original italics)." ${ }^{11}$ As such, a critical genealogy disturbs what is presented as natural to reveal the changing values by which EMU is governed. By unpacking the new calculative strategies that determine how this novel spatial-temporal order is rendered real, we gain a better understanding of the political economy of EMU.

Third, in light of the fact that half the members who have adopted the euro have also breached its fiscal rules, it is only reasonable to enquire how surveillance as regulation is being transformed as a managerial mode? Here I consider this contingency and the

\footnotetext{
${ }^{11}$ Michel Foucault, "Questions of Method," in The Foucault Effect, ed. Graham Burchell, Colin Gordon, and Peter Miller (Chicago: Chicago University Press, 1991), 76.
} 
implications it holds for the relationship between expertise and politics in managing fiscal conduct. If the mentality of government underpinning EMU is transforming, then so are the discursive frames behind European monetary integration as political technologies reflect governmental rationalities. What forms of governance does this entail and how is authority legitimised?

Explaining what "caused" the SGP crisis is not the objective. ${ }^{12}$ Rather my intention is to reveal how the revised Pact signals a different way of framing the problem of governing fiscal relation in EMU by acting on the capacity of governments as discretionary actors. This shift alters the relationship between the programmatic and operational dimensions of fiscal governance, conceptualised as a dialectic between expertise and politics, to include new forms of control and subjectification. Expertise is changing as boundaries dissolve around previously immune forms of regulation grounded in risk. Professional know-how must increasingly rely on non-aggregating/non-probabilistic methods in problematising fiscal relations and then designing the appropriate policy response.

In a similar vein to what Anthony Giddens labels as the "displacement and reappropriation" of expertise, this should be viewed as the reconfiguration of how expert authority is practiced within the euro area rather than the creation of a set of completely new institutions. ${ }^{13}$ Nor is this a binary shift but reflects the interplay of multiple determinations that together constitute this ever contested assemblage known as EMU. Through uncertainty, this continuous negotiation of how to manage fiscal profligacy

\footnotetext{
${ }^{12}$ A pro-cyclical bias deteriorated state finances and was compounded by the differential treatment of Member States.

${ }^{13}$ Aihwa Ong and Stephen J. Collier, ed., Global Assemblages: Technology, Politics, and Ethics as Anthropological Problems (Malden, MA: Blackwell Publishing, 2005), 9.
} 
produces temporary stabilisations that are increasingly susceptible to being politicised according to goals legitimated by the Lisbon agenda; otherwise referred to as "Lisbonisation."

Ratified by the European Council in March 2000, the Lisbon agenda, or strategy, declared to transform the EU into "the most dynamic and competitive knowledge-based economy in the world capable of sustainable economic growth with more and better jobs and greater social cohesion...by $2010 .{ }^{, 14}$ These structural efforts would fall within the nonbinding Broad Economic Policy Guidelines (BEPG) that states submit. Its "European Employment Strategy" was a move towards safeguarding the social model while addressing the criticisms of low growth and poor productivity performance. The implicit understanding was that European labour needed to become more responsive to supply pressures as opposed to maintaining a rigid focus on demand. Accordingly, Lisbon helps "reconnect monetary and social policy." 15 Judging by the impunity with which the SGP was torpedoed, the Lisbonisation of EMU governance apparently favours the latter as it injects competing political agendas into economic policy. Rather than a retrenchment, it was a redesign of macroeconomic governance "relying on soft coordination and voluntary policy alignments." ${ }^{16}$ Together with improved multilateral surveillance, peer pressure, and enhanced policy dialogue, Lisbon labelled this assemblage of practices as the "Open Method of Coordination" (OMC). Harmonisation was no longer the objective.

\footnotetext{
${ }^{14}$ Council of the EU, Lisbon Spring European Council: Presidency Conclusions, 23 and 24 March 2000, 5256/00, REV 1, CONCL 1(Lisbon, 2000).

${ }^{15}$ Jane Jenson and Philippe Pochet, "Employment and Social Policy since Maastricht: Standing Up to European Monetary Union," in The Year of the Euro, ed. Robert M. Fishman and Anthony M. Messina (Notre Dame, ID: Notre Dame University Press, 2006), 163.

${ }^{16}$ Daniela Schwarzer, "Transnational Consensus Building in EMU Economic Governance," in Transnational European Union: Towards a Common Political Space, ed. Wolfram Kaiser and Peter Starie (New York: Routledge, 2005), 210.
} 
Synergies are also thought to spillover from the fiscal realm. An improved Pact "contributes to achieving macroeconomic stability in the EU and plays a key role in securing low inflation and low interest rates, which are essential contributions for delivering sustainable economic growth and job creation." ${ }^{17}$ Possessing more flexibility to tailor economic strategies within this constrained discretionary space of governance allows governments to exercise a greater degree of critical judgement. Thus, expertise is being redefined to cope with this self-regulatory dimension of fiscal relations. Derived from representations of normalcy, expertise adapts to mobilise reframed perceptions of responsibility in the effort to control the conduct of Member States. This subjectification comprises a novel leverage that is exerted by the organisational SGP apparatus to modulate EMU subjects into compliance. As a modality of government, uncertainty informs the creation of this authoritative capacity to act on states. Embedded in a new technological apparatus, this articulation is the strategic recodification of power relations in EMU. A genealogy provides the comparative normality that yields a better assessment of this shift in regulation.

Simply characterising this polity as something other than the Westphalian inspired project that has come to dominate our imagination of governance heralds a shift in how we come to understand governance. After all, we are reminded that the EU is anything but a traditional nation-state. Former Commission President Jacques Delors goes so far as to describe it as an "unidentified political object." ${ }^{\prime 18}$ But is it correct to denounce the nation-state when the present SGP debacle is a product of the very interest politics that

\footnotetext{
${ }^{17}$ Council of the EU, Brussels Spring European Council: Presidency Conclusions, 22 and 23 March 2005,7619/1/05, REV 1, CONCL 1, (Brussels, 2005).

${ }^{18}$ Vivien Schmidt, Democracy in Europe: The EU and National Polities (New York: OUP, 2006), 8.
} 
buttress sovereign power? For the moment, these questions remain unanswered as we await the next seismic shock to rock EMU.

In short, whereas Foucault concerned himself solely with "national" governmentality, I expand the framework to encompass regional and international relations. As an "empirical phenomenon whose specific features are determined by contingency and context," an analytics of government allows us to appreciate how uncertainty-based rule is articulated through political rationalities and their associated programmes. ${ }^{19}$ Focusing on the actual practice of fiscal politics reveals the performative dimension of the assorted technologies of power that render EMU visible and corresponding challenges manageable. Various forms of power exist that are relevant for conceptualising the SGP as a territory of government. These include "sovereignty," which is linked to national competence over the budgetary process, "control," which is visible in the technologies of the SGP, and "governmentality," or the "conduct of conduct," which works on freedom in the construction of self-regulating subjectivities. This refines the traditional approach in IR, which primarily relies on the coercive power of sovereignty to govern. To varying degrees, these will be subsequently developed in the following chapters to provide a more comprehensive account of how behaviour is regulated in EMU.

An analytics of government does not simply reject traditional IR accounts in favour of an alternative theory of European integration. More accurately, as a new analytical instrumentality, governmentality incorporates their insights and brings their best components together. It does so because, as a set of analytical tools, it can be deployed to decipher the connection between the cognitive, moral and material political economy of

\footnotetext{
${ }^{19}$ Ronnie D. Lipschutz and James Rowe, Globalization, Governmentality and Global Politics: Regulation for the Rest of Us? (New York: Routledge, 2005), 15.
} 
interest. Thus, its interdisciplinary character resembles more of a methodological approach than a totalising theory burdened by such things as attribution bias, causality or the responsibility of establishing ontological equivalence. The value-added of this framework is its ability to redress some of the most serious deficits facing conventional $\mathbb{R}$ theories. Through its "deconstructive" and "reconstructive" ethos, we are better positioned to avoid the reliance on false dichotomies, inconsideration of various power systems, and inattention to the spatial-temporal dimensions of governance exhibited by mainstream accounts.

Of course, the governmentality approach is by no means limited to providing a better understanding of EMU. It has been successfully deployed in numerous fields and disciplines. ${ }^{20}$ But by remedying these deficits, the terrain of European political economy is revealed in the form of its discursive practices. A comparative normality now becomes more readily available, through an interrogation of the epistemological foundations of these practices, which may serve as the basis for future regulatory design. As such, an analytics of government removes the traditional obstacles to acquiring knowledge of the political, economic and social arrangements animating European integration.

\subsection{Fiscal Framework Fiasco}

The problem of fiscal profligacy and practices of responsibilisation have a contentious history. German, or Bundesbank, intentions to export and codify a model of strict fiscal austerity to the rest of Europe met with opposition at the 1996 Dublin Summit. Originally launched as "The Stability Pact" (Stabilitatspakt), German finance minister Theo Waigel stressed the necessity of buttressing the Maastricht convergence criteria by including

\footnotetext{
${ }^{20}$ David Campbell, National Deconstruction: Violence, Identity and Justice in Bosnia (Minneapolis: University of Minnesota Press, 1998); Pat O'Malley, Risk, Uncertainty and Government (Portland: The Glasshouse Press, 2004); William Walters, "Rethinking Borders beyond the State," Comparative European Politics 4 (2006).
} 
automatic penalties targeting members who joined the eurozone but breached its fiscal rules. Such draconian measures were also designed to keep the highly inflationary "Club Med" (i.e. Italy, Greece) countries out. ${ }^{21}$ Otherwise, it was believed that their lax budgetary maintenance would jeopardise the credibility of the common monetary policy. Sustained opposition from France and all but the Netherlands convinced Germany to relent and recognise the employment and "growth" dimensions of fiscal sovereignty. This meant respecting national discretion and placing the power to sanction in the hands of the Economic and Financial Affairs Council (Ecofin).

One looming threat to EMU is that governments are prone to deficit spending. The appeal of such action grows when governments are faced with recessionary pressures, as in the wake of the 2001 or 2008 economic downturns. Episodes of pro-cyclical fiscal bias have challenged this SGP ambition in the past decade with European governments increasing expenditure or cutting taxes as opposed to prudently saving in case of an economic downturn. Such was the situation precipitating the November 2003 crisis as most countries strayed from adhering to the Medium-Term Budgetary Objective (MTO) of CTBOIS and joined the "camp of the "deficit sinners.,"22 Little did the architects of EMU suspect that the profligacy problem was only going to be exacerbated by the very champion of fiscal prudence itself; namely Germany. Up to November 2003, the SGP had progressively come under attack from six states as they breached the rules. Amongst these sinners was Portugal who was the first to breach the deficit ceiling in 2001 with 4.3 percent of GDP. It was joined by Germany whose lax budgetary position deteriorated to produce a

\footnotetext{
${ }^{21}$ Today these laggards are referred to as the P.I.I.G.S.

${ }^{22}$ Martin Heipertz and Amy Verdun, "The Dog that Would Never Bite? What We Can Learn from the Origins of the Stability and Growth Pact," Journal of European Public Policy 11, no. 5 (2004): 768. Germany first violated the three percent deficit mark in 1995 , largely in part to the costs of unification.
} 
deficit of 4.0 percent in 2003. France surpassed German fiscal misconduct that same year with a 4.1 percent deficit of its own. ${ }^{23}$

A pro-cyclical policy rapidly came to be challenged as fiscally counterproductive and politically inoperative. ${ }^{24}$ Such behaviour during "good times" merely deteriorates the fiscal position of Member States. They incur higher debt levels, which prevent them from operating within the parameters of the SGP when the economic cycle turns again. This lack of fiscal flexibility has been critiqued as acting as a "straitjacket" and denounced by Romano Prodi in Le Monde (October 17, 2002) as a "stupid" pro-cyclical policy for damaging the economic position of member states at a time when expansionary measures are justified.

National politics contributed to aborting the issuance of an "early warning" to Germany and Portugal in 2001 and again to Germany in early 2002. With an election looming (October 2002), Chancellor Gerhard Schröder was afraid of the disruptive potential that a "blue paper" from Brussels would have on his campaign. "Severe domestic political problems" with "Agenda 2010" only exacerbated the issue of compliance for Germany, compelling Schröder to lobby Ecofin to veto the Commission's recommendation. ${ }^{25}$ Tensions finally culminated in the fall of 2003 . Although an "early warning" (Article 99(4)) was issued by the Commission, it failed to be activated by the Ecofin Council and ultimately proved ineffective in stymieing the excessive deficits. Under Article 104(7) of the Treaty Establishing the European Community (TEC) a

\footnotetext{
${ }^{23}$ Eurostat, "Euro-zone government deficit at $2.7 \%$ of GDP and public debt at $70.7 \%$ of GDP," News Release STAT/04/117 (September 23, 2004).

${ }^{24}$ James D. Savage and Amy Verdun, "Reforming Europe's Stability and Growth Pact: Lessons from the American Experience in Macrobudgeting," Review of International Political Economy 14, no.5 (2007):843.

${ }^{25}$ Kenneth Dyson, "Germany: A Crisis in Leadership in the Euro Area," in The Euro at 10: Europeanization, Power, and Convergence, ed. Kenneth Dyson (New York: Oxford University Press, 2008), 151.
} 
recommendation was adopted in the spring of 2003 that sought to remedy the situation by the end of the year.

Unfortunately, by June, France breached the criteria triggering the Excessive Deficit Procedure (EDP), obliging the Commission to give notice to it and Germany under Article 104(9), which stipulates a deadline for the corrections and the fiscal effort necessary to meet these (at least 0.5 percent of GDP). However, this avenue (Article 104(9)) is only viable provided that the Council adopts a supportive decision under Article 104(8). Acknowledging that they were both in violation, Ecofin nevertheless rejected deflationary Commission recommendations to sanction France and Germany. On November 25, 2003, together with Italy and Portugal, they orchestrated a blocking coalition. By virtue of a qualified majority vote, the Commission recommendation failed to obtain the two-thirds majority with only 37 of the 51 necessary votes, thus holding the EDPs in abeyance in favour of soft targets and time limits. This induced an institutional crisis in EMU, essentially "sounding the death knell for the unloved Stability and Growth Pact." ${ }^{26}$ In effect, it signaled "the amputation of the dissuasive arm of the Pact," which "had been preceded by a progressive loss of credibility of the preventive arm." ${ }^{, 27}$ Europe's fiscal framework was in jeopardy and on the brink of collapse. Given such political temperaments, uncertainty has become more pronounced as a template for fiscal relations in EMU.

What the Ecofin crisis reveals is that threats to the integrity of the SGP cannot be effectively mitigated by devising targets against which risk probabilities are assigned. Risk

\footnotetext{
${ }^{26}$ Iain Begg and Waltraud Schelkle, "The Pact is Dead: Long Live the Pact," National Economic Institute 189 (2004): 86.

${ }^{27}$ Marco Buti and Lucio R. Pench, "Why Do Large Countries Flout the Stability Pact? And What Can Be Done About It?’ Journal of Common Market Studies 42, no. 5 (2004): 1026.
} 
is ill-suited to adequately manage fiscal relations. Heralded as a standardised and "objective" system, the SGP is in fact a "contract" amongst countries to retain sovereignty over fiscal policy. Unlike a conventional contract, however, its politicised nature thwarts its enforcement by legal means. Hence, the "essence of the pact is not a mechanism of "quasiautomatic sanctions' but the institutionalisation of a political pledge to aim for low deficits (original italics). ${ }^{28}$ First and foremost, the SGP is a political protocol and fiscal indiscipline is a political failure. Whereas the SGP was devised as the anchor for EMU it has come to symbolise its weakness. As such, uncertainty has been mobilised to justify alternative forms of managing budgetary conduct linked to new strategies of calculation and issues of responsibility. These derive their resonance from the quest to represent fiscal relations in terms of normalcy. But as we shall see, this enterprise is itself fraught with contestability and uncertainty.

Even the EU-juridical structures proved inadequate in resolving this conundrum. The Commission launched an action in the European Court of Justice (ECJ) questioning the legal basis of Ecofin's decision. In July 2004, the ECJ sided with the Commission and annulled the November ruling. Nevertheless, the annulment did not indicate whether penalties should be imposed nor did it resolve the outstanding question of what to do next. It did note, however, that decisions must be made within the EDP framework and involve a Commission recommendation to suspend a procedure. Nevertheless, uncertainty became more pronounced in the forthcoming months as tempers allocated blame and Europe

\footnotetext{
${ }^{28}$ Heipertz and Verdun, "The Dog that Would Never Bite? What We Can Learn From the Origins of the Stability and Growth Pact," 770.
} 
engaged in the "painstaking reform" of its fiscal framework. ${ }^{29}$ Restitution finally arrived in March 2005 - or did it?

\subsection{A Trinity of Inconsistencies}

Three main inconsistencies in governing the euro have surfaced in light of this SGP crisis. These incongruous effects are a product of particular national forces coming into conflict with both the formalised institutional makeup of Europe as well as its unofficial processes of coordination. In light of its asymmetric constitution, characterised by a centralised monetary authority amidst decentralised fiscal regimes, EMU stability and cohesion was premised on a set of particular ideological, institutional and conceptual prescriptions. Theoretically, these were sound measures. In practice, however, their diverse demands could not be politically accommodated under the original Pact. Each one reveals a serious discrepancy between the design of Europe's fiscal framework and its actual operation.

First, it is recognised that fiscal profligacy poses a grave threat to the common monetary policy and its ultimate objective of price stability. Unsound budgetary measures threaten to increase inflationary pressures through fiscal expansion. ${ }^{30}$ As such, deficit financing undermines confidence in the stability oriented monetary policy of the ECB and must be avoided. Such orthodoxy, otherwise labelled as "new monetarism," underpins the SGP and reproduces a neoliberal regulatory response to monetary affairs. "Neoliberalism", is itself a contested concept packed full of endogenous and exogenous accounts detailing the relationships between the individual, the market, and government. As a political

\footnotetext{
${ }^{29}$ Martin Heipertz and Amy Verdun, "The Stability and Growth Pact Theorizing a Case in European Integration," Journal of Common Market Studies 43, no. 5 (2005): 986.

${ }^{30}$ Otmar Issing, "The Stability and Growth Pact: The Appropriate Fiscal Framework for EMU," International Economics and Economic Policy 1 (2004): 9; Joseph Stiglitz and Bruce Greenwald, Towards a New Paradigm in Monetary Economics (Cambridge: Cambridge University Press, 2003).
} 
rationality, it "recodes the place of the state in the discourse of politics" privileging private enterprise in place of regulatory interventions. ${ }^{31}$ A genealogy of neoliberalism, however, is outside the scope of this dissertation. ${ }^{32}$

Binding concessions are thought to prevent governments from compromising economic fundamentals. Monetarism, as a distinct challenge to neo-Keynesian demand management, holds that inflation is a monetary phenomenon. Stable prices help protect the value of assets and may be promoted by controlling the supply of money in circulation. Monetary rather than fiscal policy is the best method for accomplishing this disinflationary objective. Monetarist convictions of achieving the "good life" through disinflationary policies were embraced by the architects of EMU. Initially, this ideological commitment helped diffuse tensions between regional monetary interests (i.e. ECB policy) and national social and political ones as the SGP represented a fiscal-monetary space symbol designed as a tool for managing risk posed by fiscal indiscipline. Surveillance as regulation, rather than a supranational enforcement body, was seen as the centerpiece of the neoliberal doctrine behind this multilateral bloc. Recent events, however, challenge this position as monetarism is supposedly being subverted. As deficit-financing became embraced by even the staunchest supporters of fiscal prudence (i.e. Germany), transforming them into profligate sinners, the disciplinary power exerted by the pricing mechanisms of the market eroded.

Monetarism's power is primarily manifest through its hegemonic status as a discourse, which works to naturalise EMU as a particularly stable normality according to

\footnotetext{
${ }^{31}$ Nikolas Rose and Peter Miller, Governing the Present: Administrating Economic, Social and Personal Life (Malden, MA: Polity Press, 2008), 80.

${ }^{32}$ For a more thorough investigation of the ascendancy of neoliberalism please refer to the chapter by Colin Hay in Neoliberalism: National and Regional Experiments with Global Ideas, ed. Ravi K. Roy, Arthur T. Denzau and Thomas D. Willet (New York: Routledge, 2007).
} 
the dictates of neoliberal doctrine. The supply of money must grow at modest rates in order to prevent inflationary pressures from devaluing assets. Hence, budgetary policy must be subordinated to monetary policy. Disrupting the centrality of this conception of normalcy, underpinning the monetary union, increases the risks of governing EMU as it destabilises its foundational, ideological tenets. Arguably, the fact that half the members who have adopted the euro have also broken its rules signals the shortcomings of neoliberalism as a successful template for EMU and its disruption as the predominant mode of governance. Herein lies the ideological inconsistency.

Second, not only does this asymmetric application of the SGP further undermine the ideological consensus behind the euro but it exposes an "institutional" inconsistency apparent in governing EMU. An egregious institutional asymmetry was revealed by the crisis. A group of states (e.g. Portugal, Ireland) was subject to the statutes whereas France and Germany were deemed exempt. Multilateral surveillance should rely on some semblance of institutional equality. If the Pact is "to be applied across countries in a fair and consistent way and be understood by public opinion" then "the Council reaffirms that a rules-based system is the best guarantee for commitments to be enforced and for all Member States to be treated equally."33 To avoid recriminations, especially from compliant "small states," which only aggravate tensions within the broader EU, it is essential that discriminatory practices be eliminated, at least as much as possible. Otherwise, the integrity of EMU is undermined and its cohesiveness threatened.

Why should Member States be compelled to increase their stake in the ownership of a fiscal framework which discriminates against them? Potential adverse ramifications

\footnotetext{
${ }^{33}$ Council of the EU, Improving the Implementation of the Stability and Growth Pact (Report to the European Council, 7423/05, Brussels, 2005).
} 
exist for the Open Method of Coordination since compliant states are likely to be dissuaded from deeper, "soft" forms of integration with members who free-ride on "hard laws" and agreements. "By placing the European Council at the heart of the Union's policymaking," the OMC may actually invite further abuses as the more powerful states shield themselves from community sanctions at the expense of weaker players and the EU at large. ${ }^{35}$ This danger is only accentuated by the lack of coordination among the various regulatory agencies entrusted with checking financial books. Although some reforms were adopted in 2002 and new internal control standards and mechanisms have been introduced, their value-added is questionable. ${ }^{36}$ In this environment, the asymmetrical application of the SGP statutes also works to undermine the legitimacy of Ecofin. Again, this necessitates a rethinking of how uncertainty acts as a mentality of rule in the restoration of institutional integrity and what effect this may have on competing modes of governance like the OMC.

Third, coupled with these ideological and institutional disparities is the "conceptual" inconsistency expecting states to punish themselves and their citizens in servitude to this ambiguous entity called "Europe." The paradox is that "the declared intention is to keep political discretion at a minimum in order to prevent opportunism by governments that are both subject to, and the executors of, the Pact." ${ }^{, 37}$ Obviously, the implication for potential abuse is apparent. Herein lies the conceptual dilemma in reconciling the programmatic aspect of EMU with its operational component.

\footnotetext{
${ }^{34}$ Waltraud Schelkle, "Understanding New Forms of European Integration: A Study of Competing Political Economy Explanations," in The Political Economy of European Integration: Theory and Analysis, ed. Erik Jones and Amy Verdun (New York: Routledge, 2005), 153.

${ }^{35}$ Damian Chalmers and Martin Lodge, "The Open Method of Co-ordination and the European Welfare State," Centre for the Analysis of Risk and Regulation Discussion Paper, 11, London, June 2003.

${ }^{36}$ John Flower, European Financial Reporting: Adapting to a Changing World (New York: Palgrave Macmillan, 2004).

${ }^{37}$ Waltraud Schelkle, "The Political Economy of Fiscal Policy Co-ordination in EMU: From Disciplinarian Device to Insurance Arrangement," Journal of Common Market Studies 43, no. 2 (2005): 375.
} 
Acknowledging that France and Germany were in violation, the Ecofin Council nevertheless rejected Commission recommendations to sanction its own members. Without a fiscal union to provide economic stabilisation, the problem of noncompliance remains a considerable threat as governments appease divergent domestic interests at the expense of Community objectives. ${ }^{38}$ Politicians are shrewdly aware of who they are ultimately accountable to; namely their electorates. For the fiscal framework to be successful it must attune how it conditions the discretion of states as entrepreneurial entities, yet subjects them to collective regulatory ambitions. How normalcy is devised for these purposes is a determinant of how effective the leverage of control will prove to be in fostering compliance and possible convergence.

While all these inconsistencies amplify the challenges involved in governing EMU, they also compound an underlying conceptual conundrum which was alluded to above. The design of EMU's policy model remains opaque as the different mandates assigned to the ECB (price stability) and Member States (output stabilisation) create a de facto policy conflict. This highlights the problem of a single, centralised monetary policy operating against the backdrop of multiple and fragmented fiscal policies and its effect on the governing capacity of EU organs (e.g. Ecofin, ECB). What results is a highly uncertain strategy that is neither linear nor guaranteed in its development of a coherent and successful European fiscal-monetary space. Nevertheless, it presents an interesting empirical puzzle which poses several intriguing questions about governance in the broader field of International Relations.

\footnotetext{
${ }^{38}$ Kenneth Dyson, "The First Decade," in The Euro at 10: Europeanization, Power, and Convergence, ed. Kenneth Dyson (New York: Oxford University Press, 2008), 7.
} 


\subsection{The Discretionary Response of 2005}

In the aftermath of the Ecofin crisis, the SGP no longer diminished the perception of hazard as originally intended. This pointed to the antagonistic relationship between the programmatic (expertise) and operational (politics) dimensions of fiscal governance. At last, the response to this new environment came late March 2005 in the form of a European Council agreement entitled "Improving the Implementation of the Stability and Growth Pact." Success would depend on the strength and convergence of clear rules that favour discipline-oriented budgets and foster transparency, consistency and equal treatment. With a renewed emphasis on long-run sustainability, the surveillance capacity changed with the recognition of "differential treatment" and the accommodation of "exceptional and temporary" circumstances. ${ }^{2}$ Both components of the SGP, otherwise referred to as the "preventative" and "corrective arms," were reformed. As the terms suggest, the former is concerned with pre-empting fiscal deviance from occurring in the first place. Should this fail, the latter is comprised of mechanisms the Council can deploy to ameliorate excessive accounts and return them to normalcy. From the revamped MTBR to a comprehensive account of "other relevant factors" in the decision to invoke the EDP, the mechanistic and probabilistically aggregating methods akin to risk located in the original Pact are less visible.

First, intent on "avoiding mistakes of the past, the challenge ahead is to ensure an effective functioning of the "preventative arm' of the Stability and Growth Pact." ${ }^{\text {3 In order }}$ for this general EMU ambition to be realised the precautionary measures of the SGP needs

\footnotetext{
${ }^{1}$ Council of the EU, Improving the Implementation of the Stability and Growth Pact (Report to the European Council, 7423/05, Brussels, 2005).

${ }^{2}$ Council of the EU, Improving the Implementation of the Stability and Growth Pact.

${ }^{3}$ European Commission: DG for Economic and Financial Affairs, European Economy: Public Finances in EMU 2007 (Brussels: DG EcFin, 2007), 3.
} 
to be more effective. This entails a twofold approach. Initially, as is stated in the March 2005 Council report, "domestic governance arrangements should complement the EU framework."4 Coordination of national fiscal policies in the eurozone must be enhanced. Strengthening the preventative arm necessitates having a more effective "early warning mechanism" (Regulation 1466/97) to prevent excessive deficits. ${ }^{5}$ Such collective surveillance methods monitor the medium-term annual Stability and Convergence Programmes (SCP) submitted by EMU members. ${ }^{6}$

Country-specific MTOs, notably those pertaining to the sustainability of government finances, are another primary hallmark of the 2005 reforms and the transition to uncertainty-centred regulation. The basic rules delineating the reference values have been retained. However, a change in economic rationale eliminated the uniform requirement of CTBOIS and replaced it with these new methodologically clarified and differentiated MTOs. For the first time, these differentiated MTOs must now be included in the SCPs. ${ }^{7}$ This is geared to enhancing the role that SCPs play in the national budgetary process by fostering coordination among the various departments and agencies involved in drawing up budgets together with their respective national legislatures. Furthermore, this change also addresses the charge that SCPs were purely passive by subjecting them to democratic debate and responsibility. The promotion of national fiscal ownership is the objective. $^{8}$

\footnotetext{
${ }^{4}$ Council of the EU, Improving the Implementation of the Stability and Growth Pact (Report to the European Council, 7423/05, Brussels, 2005).

${ }^{5}$ European Commission: DG for Economic and Financial Affairs, European Economy: Public Finances in EMU 2006, 43.

${ }^{6}$ The convergence programmes of non-euro Member States are also presented to Ecofin.

${ }^{7}$ MTOs are differentiated on the basis of debt rations and potential growth.

${ }^{8}$ Sylvester Eijffinger, "On a Reformed Stability and Growth Pact," Intereconomics (2005): 142.
} 
Consecutively, favourable cyclical conditions (neglected in favour of "total" deficits in the original SGP) must be exploited to bolster sustainable fiscal positions. Fresh provisions are measured in cyclically adjusted terms. The consensus is that Member States should "take active steps to reach the MTO and make larger structural efforts in good times." ${ }^{9}$ Here successful budgetary surveillance demands that appropriate economic measurements be employed to indicate the particular fiscal conditions of individual states. Recent “creative accounting" scandals, most notably Greece's consecutive production of fictitious budgetary data, but also discrepancies found in Italy, demand greater accountability and transparent verification. ${ }^{10}$ The preventative arm focuses on long-term sustainability.

Aside from the 3 percent deficit ceiling safety margin and a path towards sustainability, the revised SGP states that MTOs should also permit room for budgetary manoeuvre, especially in regards to the needs for public investment. ${ }^{11}$ With the impending expenditure increase resulting from an ageing population, governments need to incorporate qualitative elements on top of quantitative ones. Such broader implicit liabilities complement an uncertain environment and more subjective estimations of how to govern. Analysing the public finances of the eurozone for 2006 a significant improvement is noticeable since the 2005 reforms were instituted. Down from 2.5 percent of GDP in 2005,

\footnotetext{
${ }^{9}$ European Commission: DG for Economic and Financial Affairs, European Economy: Public Finances in EMU 2006, 91 .

${ }^{10}$ Vitor Calderia, "The Coordination of Internal Controls: The Single Audit-Towards a European Union Internal Control Framework," in Public Expenditure Control in Europe, ed. M.G. Crespo (Northampton: Edward Elgar, 2005), 184-90.

${ }^{11}$ European Commission: DG for Economic and Financial Affairs, European Economy: Public Finances in EMU 2006, 65.
} 
the headline deficit fell to 1.6 percent. ${ }^{12}$ DG EcFin attributes some of these gains to the new preventative surveillance apparatus.

Arguably, it is the SCPs that influence budgets and not vice versa. Therefore, to draft an annual budget in a sustainable policy plan, which is embedded in a broader EMU framework, the MTBR is performed before the summer. In its revamped form, the MTBR corresponds more to national fiscal calendars and invites Member States to forward their policy intentions for the forthcoming year in order to foster a dialogue about budgetary projections. Such an initiative is thought to reduce the dangers surrounding the coordination of national fiscal policies in the eurozone. It allows the Commission a better opportunity to structure the ensuing MTBR discussion. ${ }^{13}$ This can result in a more in-depth strategic policy discussion that focuses on areas in need of improvement. Although statistical calculations are visible, they often complement uncertainty-based procedures. These practices attempt to regulate national idiosyncrasies and the discretionary temperament of politicians and officials by subjecting them to that "infrastructure of referentiality" against which fiscal conduct may be evaluated and regulated. ${ }^{14}$

Second, the "corrective arm" stipulates the exact rules for fiscal misconduct. Its primary mechanism is the Excessive Deficit Procedure. Considered hard law, it warns against breaching deficits of 3 percent to GDP and debt levels of 60 percent to GDP. Trumpeting differential treatment, the corrective arm is now more accommodating of "exceptional" circumstances. In addition to the cyclical adjustment of budget deficits, "one-

\footnotetext{
${ }^{12}$ Core inflation in March 2008 was $2.7 \%$, up from $2.4 \%$ in February. Acceleration in oil, commodity and food prices constitute the main elements behind the current record-high level of headline inflation, available from http://ec.europa.eu/economy_finance/publications/publication12486_en.pdf

${ }^{13}$ European Commission: DG for Economic and Financial Affairs, European Economy: Public Finances in EMU 2007, 73 .

${ }^{14}$ Michael Power, Organized Uncertainty: Designing a World of Risk Management (New York: Oxford University Press, 2007), 197.
} 
off" and "temporary measures" were also introduced. ${ }^{15}$ A form of collective surveillance, the EDP concentrates on the short-term and the semi-annual observation of national budgetary data. Every March 1 and September 1, the Commission and DG EcFin determine whether an excessive budget deficit exists. Should either the deficit or debt ratios be breached then the EDP is triggered according to Article 104 of the TEC. If the charge is deemed legitimate by Ecofin, the country is provided with recommendations on how to remedy the problem. Failure to comply may generate sanctions (e.g. non-interest bearing deposits to the EU, fines). Hence, the EDP is considered a dissuasive tactic where qualitative assessments are becoming more pronounced.

With a renewed emphasis on long-run sustainability, the surveillance capacity changed with the recognition of differential treatment and the accommodation of "exceptional and temporary" circumstances. In expanding the discretionary power of EU experts and officials, the (re)politicisation of fiscal relations becomes more visible. ${ }^{16}$ As a governmental template, uncertainty targets the variability and diversity of political decision-making. Critical judgement becomes more paramount in appraising fiscal conduct and in the execution of the new Pact. Aggregating methods akin to risk diminish in utility in unique situations where a probability distribution cannot be quantified to indicate and evaluate Member State performance. As a "crude fiscal coordination mechanism" the SGP leaves substantial room for political manipulation. ${ }^{17}$ Thus, subjective estimations, which are undoubtedly susceptible to political bias, populate the contemporary scene of

\footnotetext{
${ }^{15}$ Alan W. Cafruny and J. Magnus Ryner, Europe at Bay: In the Shadow of US Hegemony (Boulder: Lynne Rienner, 2007), 34.

${ }^{16}$ A clarified division of labour distinguishes assessment, by granting the Commission the "right to bark," from decision-making, or the "right to bite," which still falls exclusively into the province of the Council.

${ }^{17}$ Patrick Crowley, "The Shape of Things to Come: The EU's Post-EMU Institutional Architecture," in The Euro: European Integration Theory and Economic and Monetary Union, ed. Amy Verdun (Lanham, Md.: Rowman \& Littlefield Publishers, 2002), 166.
} 
uncertainty. This rearticulation of uncertainty into the political imagination of EMU is creating new forms of expertise and regulatory capacities, which often overlap and blur.

Nevertheless, most commentators would agree that the SGP has indeed been further weakened with the March 2005 reforms. ${ }^{18}$ A primary deficiency associated with the original SGP remains. National fiscal ownership of the Pact is still lacking. Compliance does not depend solely on a new fiscal framework. As Buti notes:

if the problem is primarily one of adherence to the rules, the priority should be to ensure rigorous implementation of the existing rules rather than to change them. At the same time, it is widely recognized that simply attempting to apply the existing rules after the watershed of November 2003 is not a viable option. Re-establishing a sense of ownership of the fiscal rules by all parties would be the precondition for their effective enforcement. ${ }^{19}$

Indeed, a successful SGP cannot neglect that national fiscal ownership rests on the internalisation of self-regulation by Member States. Convergence between national interests and EU objectives demands forecasts, analyses and recommendations that are specifically tailored to each individual member state and their unique interests rather than vague and generic ones. Given that these relationships are highly politicised the internalisation of self-regulation is fostered by the convergence of national preferences as the option of defection becomes less attractive.

Flexibility in defining normal fiscal conduct is crucial to accommodating state interests and Community ambitions. Risk lacks this property. Conversely, uncertainty incorporates creative entrepreneurialism as it helps refocus responsibility. Member states are considered enterprising subjects assigned the duty of prudently managing their fiscal

\footnotetext{
${ }^{18}$ Waltraud Schelkle, "EU Fiscal Governance: Hard Law in the Shadow of Soft Law?" Columbia Journal of European Law 13 (2007): 705-31.

${ }^{19}$ Marco Buti, "Will the New Stability and Growth Pact Succeed? An Economic and Political Perspective," January 2006, available from http://europa.eu.int/comm/economfinance/publications/economic_ papers/2006/ecp241en.pdf; Internet, Retrieved 09/01/06.
} 
books. It simultaneously "enables and opens up new possibilities for its subjects, and restrains these subjects as they are made subjects of a certain calculative and disciplinary regime. ${ }^{20}$ National fiscal ownership may be enhanced as the government through uncertainty introduces a self-regulating element to the organisation of the SGP. It provides a new infrastructure of referentiality by which to determine normality and thus responsibility. By internalising notions of normalcy, negotiated to accommodate their unique contingencies within the context of EMU, states are more amenable to accept responsibility for their fiscal conduct.

\subsection{Governmentality and Uncertain Trajectories}

This dissertation is making two sets of claims. One set refers to an emerging phenomenon that is coming into being; namely this fiscal-monetary space called EMU. More than simply the aggregate of individual national economies, its construction is rendering certain pressures, arising out of its organisation, visible. These operational dynamics conflict with the SGP's original programmatic objectives. The second set of claims concerns how governance is changing to reflect these tensions and its effects on European political economy. How is surveillance as regulation adapting to deal with the problem of fiscal profligacy? I submit that "governmentality," as a new analytical instrumentality, directs our attention to a novel set of discursive practices that help constitute conceptions of normalcy as anchors for fiscal relations in this emerging space. It is this rearticulation of what is considered normal fiscal conduct that helps to legitimise new forms of responsibility upon which surveillance is based. Uncertainty is a modality of government that informs this

\footnotetext{
${ }^{20}$ Jens H. Haahr, "Open Co-ordination as Advanced Liberal Government," Journal of European Public Policy 11, no. 2 (2004): 209.
} 
transition. The effect is the recodification of new forms of control that respect fiscal sovereignty and Community protocol.

Through this interdisciplinary approach we gain an enhanced understanding of the movement to organise EMU as a regulatory regime by bridging literatures that otherwise rarely "speak" to one another, namely International Political Economy (IPE) with that of critical social theory and risk. New insights are generated into the management of EMU by deploying a set of analytical tools, not commonly found in IPE, to the study of EMU governance. A critical genealogy helps ascertain how truth claims are constructed by dissecting the very discourses, institutions and technologies employed in their actualisation. I excavate the governmental terrain of the SGP to reveal how knowledge, as a susceptibility to vulnerable fiscal conduct and as a register of responsibility, is constituted and legitimated in the production of responsible EMU subjects.

A genealogical approach draws our attention to how the limits of this fiscalmonetary space are (re)politicised via the power relations that constitute them and the techniques of government through which they are articulated. Governmentality helps us understand how uncertainty shapes the control of conduct and introduces a semblance of parsimony into the management of European fiscal affairs. An excavation of this very technocratic landscape reveals not a uniform and a priori entity labelled "risk" or "uncertainty" but the historical emergence of specific discursive practices aimed at curbing profligacy. Temporality is fundamental in this exercise because it reminds us that uncertainty is itself about contingency and acting according to the circumstances. Born in a period of "good times," EMU is implicated in a vortex of disjunctions and accelerations 
that inhibit the guarantee of a universal permanence. Uni-linear readings of time neglect temporal flux but governmentality does not.

How time is imagined through the governmental construct of uncertainty opens new spaces where the political is articulated. Drawing on Machiavelli, Walker emphasises that such discursive constructions are time bound, prompting one to "abandon the possibility of transcending the contingencies of time through an appeal to Being or eternity." 21 Perhaps uncertainty does call for the amelioration of Fortuna's temperaments according to dictates of normalcy. But it is still a historical innovation that must be interrogated in the context of the political. Fiscal relations are that context. Through the processes of inscription and signification, the meanings that are attributed to various EMU categories and subjectivities as registers of normalcy, indissolubly intertwined with notions of responsibility, are produced. ${ }^{22}$ Contestable in nature, these methods regulate which articulation of subjectivity is validated.

Keep in mind, however, that risk and uncertainty are not to be treated as either analytically real or unreal. Determining the tangibility of a specific threat is not the intention. ${ }^{23}$ This relationship is not one of mutual exclusion. Neither risk nor uncertainty is inherently more or less abundant in this post-2005 reconfiguration of the fiscal framework. To understand this process as merely denoting the exchange of one class of variables for another is to miss the more interesting governmental dimension to this problematic. After all, there is not a rigid binary opposition between these modes of governance. Rather the

\footnotetext{
${ }^{21}$ R.B.J Walker, Inside/Outside: International Relations as Political Theory (New York: Cambridge University Press, 1993), 40.

${ }^{22}$ Colin Gordon, "Governmental Rationality: An Introduction," in The Foucault Effect, ed. Graham Burchell, Colin Gordon, and Peter Miller (Chicago: Chicago University Press, 1991).

${ }^{23}$ Whether or not objective knowledge is acquired as a capacity for future behaviour is of little concern. Given their permanent state of virtuality, ontological questions are rendered peripheral. Instead, attention is devoted to understanding how the governmental rationalities underpinning EMU are framed and articulated in these terms.
} 
relationship between risk and uncertainty is contestable and heteromorphic. They are configured together in "lines of continuous variation that can never be homogenised into a linear process of change or transformation." ${ }^{24}$ Accordingly, uncertainty is qualitatively different than risk because in these situations "agents cannot anticipate the outcome of a decision and cannot assign probabilities to the outcome., 25

On the other hand, risk management is an attempt to control the future by recasting the past. It is backward looking. As a risk-based system, the objective was to foresee and mitigate threats to the integrity of the SGP by devising targets against which probabilities could be assigned. However, EMU is confronted by a consistent stream of failures that challenge this organisational capacity to mitigate potential hazards by institutionalising a governmental response to profligacy. These perils do not lend themselves to probabilistic calculations as the idiosyncrasies of human behaviour cannot be readily accounted for using conventional risk analysis. Their unique character prevents an ex ante delivery of a regulatory response. In such an unstructured environment like this fiscal-monetary space, which fails to reproduce itself at regular intervals, a uniformly collectivised approach is virtually impossible. A new orientation is necessary that can compensate for contingency and its unexpected consequences while simultaneously providing some semblance of control over the future. Uncertainty, as an analytical construct and mode of governance, is instrumental in this manner.

Given the number of promising intellectual points of departure, including the recognition of EMU as an economic construction in process, the discursive constitution of

\footnotetext{
${ }^{24}$ Mitchell Dean, "Putting the Technological Into Government," History of the Human Science 9, no.3 (1996): 56.

${ }^{25}$ Jens Beckert, "What Is Sociological about Economic Sociology? Uncertainty and the Embeddedness of Economic Action," Theory and Society 25, no. 6 (1996): 804.
} 
this emerging fiscal-monetary space is surprisingly underdeveloped in the field of IR. Conventional accounts continue to rely on old approaches that fail to appreciate this changing problematic of EMU governance by simply applying dated categories and methods to what is, arguably, the construction of a novel spatial-temporal order. Not only are risk and uncertainty taken for granted without any serious analysis of their epistemological foundations, but they are often used arbitrarily and interchangeably in an effort to denote variance as a tangible phenomenon. Tendencies such as this simply aggravate the fictitious dichotomy between the ideal/political and the material/economic identified above. I, on the other hand, prefer to adopt the distinction made by the likes of Pat O’Malley or Mark Blyth, with roots in Knightian conceptions of uncertainty. ${ }^{26}$

To redress these common IR deficiencies, it is vital to present how the terrain of EMU actually operates. Rather than imposing our cognitive frames onto the study of fiscal governance - typical of the mainstream literature - a better approach is to recognise that the political economy of EMU is revealed in the form of its very practices. Within these relational fields, the interplay of diverse and contested political, economic and social forces together constitute international politics itself. As opposed to advocating a macroanalysis, which hints at risk as an underlying reality behind EMU, or microeconomic marginal utility modelling - with its fallacious abstractions - a preferred approach is to acknowledge the historical contingency underpinning fiscal relations and their respective modalities of rule. Through an analytics of government, this discursively relational dimension of EMU enriches our understanding of how the European political economy is envisioned and continuously constructed and renegotiated.

\footnotetext{
${ }^{26}$ Frank Knight, Risk, Uncertainty and Profit (New York: A.M. Kelley, 1921/1964); Mark Blyth, Great Transformations: Economic Ideas and Institutional Changes in the Twentieth Century (New York: Cambridge University Press, 2002); Pat O'Malley, Risk, Uncertainty and Government.
} 
It draws attention to the "performativity" of uncertainty (and risk) in the constitution of subjectivity. How we come to understand EMU subjectivity, categories and processes is often taken as self-evident or given in IR and seldom problematised. However, according to Judith Butler, these are not stable identities but rather contestable and dependent on "a compulsory repetition of prior and subjectivating norms, ones that cannot be thrown off at will, but which work, animate, and constrain the...subject." ${ }^{27}$ EMU relies on performative technologies to project a particular vision of what is considered appropriate behaviour in order to enforce a convergent set of fiscal practices across different contexts. Regulators deploy a battery of ideas/discourses (e.g. monetarism) and technologies (e.g. SCP) at dispersed sites to generate certain state effects and render this space real for the purposes of minimising hazards and yielding politico-economic gains. Governmentality helps us to appreciate uncertainty as a dominant mentality underpinning the constitution of EMU. This allows for a better diagnosis of how this emerging space becomes an object of inquiry and susceptible to the interplay of diverse politico-economic forces.

\subsection{Problematising Organisational Management: Plan of Dissertation}

My dissertation is concerned with deciphering the trajectory of governing EMU by analysing how fiscal management is influenced by the politics of risk and uncertainty associated with fiscal profligacy. Here "encountering risk is above all an event of problematization which places in question existing attention to risk and its modes of identification, recognition and definition. ${ }^{, 28}$ What this line of enquiry demonstrates is that

\footnotetext{
${ }^{27}$ Frederick Roden, "Becoming Bulterian: On the Discursive Limits (and Potentials) of Gender Trouble at Ten Years of Age," International Journal of Sexuality and Gender Studies 6 (2001): 27.

${ }^{28}$ Bridget Hutter and Michael Power, Organizational Encounters with Risk (Cambridge: CUP, 2005), 11.
} 
problematising and deconstructing the SGP is instrumental in helping understand how governance is affected by the movement to an organisational capacity from one centred around risk, with an emphasis on quantitative targets, intervention and sanctions, to one where uncertainty is increasingly visible. We come to understand how the SGP represents a fiscal-monetary space symbol and method of managing hazards in the name of normalcy.

Revealed in the negotiated manufacture of this space is the contradictory nature of organisational (programmatic) and political life (operational). Without any overarching, fiscal authority to delegate and enforce SGP statutes or distribute funds, EMU faces major challenges in enforcing budgetary compliance. It relies on specific discursive practices to produce fiscal discipline. The temporary stabilisations that results, however, are not uniform or constant but rather historically contingent and contestable. An analytics of government allows me to render visible these tensions between the constituting and destabilising forces of EMU. To do so is to highlight the ideological, conceptual and institutional dimensions underpinning the problematic.

Distinguishing between risk and uncertainty in relation to the changing problem of fiscal governance helps situate the study of the SGP by indicating how meaning is inscribed and represented. Furthermore, such an understanding is conducive to rethinking how governance is delivered after November 2003. Investigating how these mentalities of government are inscribed into the fabric that constitutes EMU requires a focus on the materiality of discourse. By connecting discourse analysis to the "invention and assemblage of particular apparatuses and devices for exercising power and intervening upon particular problems," EMU is rendered intelligible as an emerging regulatory space 
and becomes open to critique and modification. ${ }^{29}$ My dissertation dissects this array of discursive practices to demonstrate the movement to a government through uncertainty from one primarily rooted in risk. This transition is reflective of the need to reintroduce discretionary, human expertise and estimation into the management of fiscal affairs. Such a genealogy reveals how EMU is constructed as a novel spatial-temporal order with its own set of articulations and regulatory capacities.

The following argument is developed in five stages. In Chapter 2, I catalogue and critique several of the more prominent conventional accounts of the SGP crisis. My analysis encompasses "liberal intergovernmentalism" (IG), an ideationally focused "constructivism," and a "critical political economy" (CPE) rooted in regulation theory and supplemented by the neo-Gramscian framework. I reveal how their theoretical deficits detract from a sound understanding of the 2003 SGP problematic itself and the reforms it engendered. Any indication of how risk and uncertainty are transformed into modes of governance is also absent from these mainstream theories. Aside from certain constructivists, who recognise that the management of contingency actually entails the management of systems of representation, the majority of liberal intergovernmentalists and historical materialists take these calculative practices for granted or subscribe to the "risk society" thesis. They fail to acknowledge that risk and uncertainty represent different classifications of social phenomenon, which inspire specific problematisations at demarcated sites of contestation. Instead, risk is treated as a monolithic technology, which reinforces a fictitious subject/object dichotomy.

Given that the field of IR exhibits an ontological bias or "fetish" this advocated facticity is not surprising. For Jarvis and Griffiths, "the problem for IR remains the

${ }^{29}$ Nikolas Rose, Powers of Freedom (New York: Cambridge University Press, 1999), 19. 
ideological chasm that continues to define the intellectual epicentre around which scholarly debate occurs, delimiting the emergence of newer and perhaps more innovative research agendas. ${ }^{30}$ Both implications are quite grave as these epistemological deficits detract from the explanatory value of mainstream accounts of EMU. By challenging IG and the sovereignty problematic, with its prior political agency and economistic conception of power as a commodity, I demonstrate the contestability implicit in the constitution of EMU subjects and objects of knowledge. Questioning defined boundaries leads to a more comprehensive understanding of the politicisation of limits and how they are articulated. How truth claims arise and are legitimated will allow us to "stress the contextuality and historicity of all claims to knowledge" and "reject any universalistic, positivist account of reality, deny the facticity of the subject-object duality, allow for the coconstitution of subjects and objects, and eschew economic reductionism."31

Following this discussion, Chapter 3 introduces how I operationalise the governmentality framework as a superior approach to helping overcome conventional theoretical deficiencies in order to provide a better understanding of EMU. Here I explicate its deployment to comprehend the transition in the fiscal management of EMU through risk-centred formulas of rule to that of uncertainty. By deciphering how uncertainty is deployed in the context of EMU, we can retrace the problematisations of fiscal management to which it is presented as solutions. This places us in a better position to grasp the very conditions that render EMU a governable space. As a set of analytical tools, governmentality helps us recover a particular meaning of EMU with identifiable

\footnotetext{
${ }^{30}$ Darryl S.L. Jarvis and Martin Griffiths, "Risk and International Relations: A New Research Agenda?" Global Society 21, no. 1 (2007): 2.

${ }^{31}$ Bob Jessop and Ngai-Ling Sum, "Towards a Cultural International Political Economy: Poststructuralism and the Italian School" in International Political Economy and Poststructural Politics, ed. Marieke de Goede (New York: Palgrave Macmillan, 2006), 159.
} 
parameters, power systems and mentalities of rule predicated on contingency. The SGP is the very terrain where identity, interests, and power itself are constituted. An array of power systems exists that are visible in the conceptualisation of the SGP as this territory of government. In addition to "sovereignty" and "discipline," forms of "control" are proving more prominent with the emergence of uncertainty as a dominant modality of rule. Acknowledging that failure is possible across multiple sites of this EMU assemblage, the "modulation" of conduct programmed into daily practice reveals various insights into the changing face of governance. ${ }^{32}$

Having established the parameters of the governmentality framework, I move to a discussion of risk and uncertainty as key questions about modes of governance. By problematising the categories that conventional theories take for granted, this section focuses in more depth on the connection between risk management as a style of governing the SGP and the specific rationalities and practices imported into the European public domain from the private sector. ${ }^{33}$ Since the three primary categories of risk that I wish to analyse (operational, reputational, and internal control/institutional) are not indigenous to EMU but have migrated into this realm from the corporate sector, this permits me to reconstruct the particular lineages across Europe's politico-institutional space. Granting authority to risk management models reinforces a tendency to accept these instruments without problematising their legitimacy. Subsequently, this immunity magnifies the power of the neoliberal paradigm as it provides an authoritative capacity not subject to traditional channels of accountability.

\footnotetext{
${ }^{32}$ Gilles Deleuze, "Control and Becoming," in Negotiations, ed., trans. by Martin Joughin (New York: Columbia University Press, 1995), 169-176.

${ }^{33}$ A substantial amount of these are banking and commerce based where profit-maximization is usually synonymous with efficiency and risk minimization. Connected to this is 'financial auditing' with its emphasis on accountability and quality control measures.
} 
Although statistical data and computations continue to be employed, their utility is very much in question in situations where a calculable probability cannot be assigned. Compounded by their failure to accurately forecast some of the most daunting crises, such as the SGP debacle or the depth of the current market correction, risk metrics are proving inapplicable for shedding light on large swathes of political and economic life where uncertainty prevails. An analytics of government reveals how the onus is shifting towards human competencies and critical judgement in ascertaining how to navigate through such unchartered waters. Creative thinking is reasserting its value in relation to risk management, which may be considered an exercise in the application of predefined quadrants. In the process, expertise is reformulated to manage the obligations of contingency. No longer are officials, shielded by abstract formulas and a defendable process, devoid of responsibility for their decisions. Calculation and responsibility are fused through these new technologies of government.

Once the analytical instrumentality of governmentality is established, I apply these very tools in Chapter 4 to conduct a genealogical analysis of the discursive practices that constitute the underlying shift in modes of regulation. How have the architects of EMU intervened to render EMU a governable space? Both the preventative and corrective constellations of the revised Pact are interrogated. Dissecting how extensively the discourse of "good times," and its relationship to that of "national fiscal ownership," has penetrated European practice and institutions, I investigate how the push for public management reform encapsulates ideals of public value creation. Following this discussion, I turn to the technologies of government that are reconfiguring the fiscal landscape in Europe according to the logic of uncertainty. Ranging from a stronger role for the MTBR to enhanced SCPS 
that encompass MTOs for the very first time to a more comprehensive account of "all other relevant factors" in the decision to invoke the EDP, these very mechanisms are commensurate with the rationality of uncertainty as a template for EMU governance.

At once, there are two thematic dimensions to this dissertation. First, the "deconstructive" thematic seeks to interrogate budgetary management in order to reveal how the problem of fiscal profligacy affects European political economy. Second is the "reconstructive" thematic, which is concerned with evaluating how this regulatory space is being reassembled through specific practices of representation/truth production that embody a performative element delimiting the discursive constitution of EMU as an object and subjects of government.

Such an analysis reveals how the dialectic between expertise (programmatic) and politics (operational) is reconfiguring the leverage of uncertainty in efforts to modulate EMU subjects and balance debt sustainability with fiscal stabilisation. My sketch of this regulatory capacity encapsulates a discussion of the performative character of this changing relationship. As this assortment of discursive practices disrupts the artificial uniformity of risk management, it grants constitutive authority to non-quantitative methods anchored in critical judgement, thereby reconfiguring expertise and politics within EMU. This allows for a more comprehensive understanding of fiscal governance.

In Chapter 5, I develop how normalcy acts as a template against which modes of governance are evaluated. Governmentality directs our attention to the diverse set of discursive practices that help constitute conceptions of normalcy as anchors for fiscal relations in this new space. How truth claims are constituted is revealed by dissecting the very discourses, institutions and technologies employed in their actualisation. It is possible 
to understand the changing composition of surveillance in terms of the legitimacy granted to new conventions of responsibility through the rearticulation of normal fiscal conduct. Control is recodified to ameliorate the friction between fiscal sovereignty and Community protocol.

Any serious discussion, however, of the construction of normalcy in EMU is noticeably absent from conventional accounts. This is surprising since, as Ian Hacking reminds us, normalcy "has become one of the most powerful ideological tools of the twentieth century." ${ }^{34}$ To divorce the SGP from political reason by resigning ourselves to a totalising vision of normality hampers our capacity to understand the changing nature of EMU governance. If anything, the SGP crisis has demonstrated that subscribing to a single design of normalcy is impossible when dealing with such a multifarious and factional socio-political creation as EMU. A universal definition seems erroneous when such variegated conceptions of a normal budgetary standard persist. Because of this diversity and variability, the local knowledge of national politicians and officials become ever more important in plotting an appropriate course of action.

Accommodating these competing notions of normalcy within the new Pact entails a transformation in the expression of expertise. How appropriate fiscal conduct is represented becomes a constitutive and formative element in the legitimation of the calculative practices that regulate this space. But it is more than simply a reflective role since these various technologies of representations have a performative character in that they construct the reality that they seek to describe. Such a diagnostic approach allows me to excavate the territorialisation of new geographies of power produced by the 2005 SGP reforms as a response to the Lisbonisation of fiscal relations.

\footnotetext{
${ }^{34}$ Ian Hacking, The Taming of Chance (New York: Cambridge University Press, 1990), p. vii.
} 
They challenge the institutionalisation and purported legitimacy of risk-centred "qualculation" by focusing attention on the singular, micro-level calculative practices which together comprise the SGP regulatory regime. "Qualculation" is a term Nigel Thrift employs to denote the "activity arising out of the construction of new generative microworlds which allow many millions of calculations continually to be made in the background of any encounter." ${ }^{35}$ Being especially ubiquitous these vast computing systems are often present in highly specialised domains like monetary economics. Their reach virtually transforms their activity into "qualitative" judgements, further depoliticising governance. Uncertainty fosters new technologies for modulating fiscal conduct that were not visible with the original Pact. New sites of articulation emerge where the discourse of good times is visible in the constitution of EMU subjectivities and the promotion of national fiscal ownership.

Underpinning this redesign is a novel approach to the disposition of informal expertise. A greater reliance is increasingly being placed on human expertise in interpreting propensities towards failure and hedging against them. This disturbs the power and performative capacity of numerical figures and statistical modeling in the production of EMU subjectivities. New forms of knowledge define the parameters of EMU as a recognisable and governable space. Thus, "power is embedded within the discursive formations that naturalise normality and that motivate the reproduction of normal populations through associated practices." ${ }^{36}$ This is located within a wider field of transnational and state surveillance practices that deploy normalcy to foster national

\footnotetext{
${ }^{35}$ Nigel Thrift, "Movement-Space: The Changing Domain of Thinking Resulting from the Development of New Kinds of Spatial Awareness," Economy and Society 33, no. 4 (November 2004): 584.

${ }^{36}$ Ronnie D. Lipschutz and James Rowe, Globalization, Governmentality and Global Politics: Regulation for the Rest of Us? (New York: Routledge, 2005), 56.
} 
ownership in multiple areas. Aside from the fiscal domain, peer monitoring and steering are facets of diverse governmental regimes witnessing the reabsorption of the technocratic into the political. A comparison with the international campaign combating public sector corruption draws some of these parallels. Addressing these issues will allow me to extrapolate to broader contexts where similar problems are visible. Through this analysis we will gain an enhanced appreciation of the global resonance of the effort to mobilise the endogenous responsibility of states to manage their own affairs.

Chapter 6 will revisit the principal insights and arguments presented in the dissertation. This will provide an opportunity to reflect on certain tensions and deficits that arise within the governmentality framework. Two future oriented comments will be made. One will be empirical in nature and concern the development of public policy as the world's economies struggle out of the grips of the global credit crisis and the "great recession." The other will touch upon the theoretical value-added of governmentality in explicating this fragile recovery process. Together, they elucidate how the art of government is attentive to the unknown and the manner by which it translates that knowledge of contingency into concrete methods in the organisation of international relations. 


\section{Chapter 2 Theoretical Deficits: Dated Categories and Methods}

Acknowledging the conceptual, ideological and institutional questions raised by the differentiated assessment and implementation of the Stability and Growth Pact, my dissertation seeks to problematise how this affects the governance of the eurozone. Denaturalising EMU, as mentioned, is conspicuously absent from much of the IR literature irrespective of the importance of the debate. Various scholars and analysts have espoused contending explanations for understanding the coordination, or lack thereof, of economic policy within Europe but not how this space called EMU becomes the site of its own economy? What effect the differentiated assessment of SGP statutes has on the composition of this space is largely neglected in favour of what Walters and Haahr label as a "set of assump-tions" where "Europe exists within its parameters as a 'known quantity/quality.", All that is necessary is to unearth these properties.

Three of the most influential approaches that succumb to this deficiency are liberal intergovernmentalism, a constructivism emphasising ideational/elite consensus, and a critical political economy embedded in the neo-Gramscian framework. As telling as these accounts of EMU may be, and in particular constructivism, they fail to adequately explain the shift in modes of regulation precipitated by the SGP crisis and how governance, as a political rationality and regulatory capacity, is devised to contend with uncertainty. Not only are their answers to the conceptual and ideological dimensions of this problematic quite questionable but they are all substantially weak in problematising EMU management in light of the asymmetric application of the SGP. Adequate answers proposing a new institutional capacity to address this dilemma are also markedly absent.

\footnotetext{
${ }^{1}$ William Walters and Jens Henrik Haahr, Governing Europe: Discourse, Governmentality and European Integration (New York: Routledge, 2005), 2.
} 
Compounding these deficits is the lack of any serious analysis donated to how systems of representation help construct the material reality of EMU and the role that technology plays in which discourse is embedded. But "considering the manifest political consequences of adopting one mode of representation over another" is fundamental to understanding how this emerging fiscal-monetary space is rendered real. ${ }^{2}$ This requires us to reject the fictitious dichotomy between the material and ideal to which the conventional literature subscribes. EMU encompasses a panoply of technologies and discourses aimed at controlling the representation and therefore the actualisation of a particular system. Making sense of how this space labelled "EMU" is organised and made thinkable for the purposes of government allows for a better assessment of its relative merits as a field of intervention.

Normalcy is central to steering organisational thinking and societal practices. Ian Hacking observes that:

chance made the world seem less capricious: it was legitimated because it brought order out of chaos. The greater the level of indeterminism in our conception of the world and of people, the higher the expected level of control. ${ }^{3}$

The supposed paradox captured in the above quote is at the heart of Hacking's venture into explaining how determinism was subverted by laws of probability. In The Taming of Chance, he provides a philosophical analysis of the multiple ways that truth-or-falsehood may be formulated for the purpose of social control. ${ }^{4}$ Central to this argument is the invention of normalcy. Often defined in opposition to the pathological by scholars such as Durkheim, normality, according to Hacking, has become one of the most fundamental

\footnotetext{
${ }^{2}$ David Campbell, Politics without Principle: Sovereignty, Ethics and the Narratives of the Gulf War (Boulder, CO: Lynne Rienner, 1993), 7-8.

${ }^{3}$ Ian Hacking, The Taming of Chance (New York: Cambridge University Press, 1990), vii.

${ }^{4}$ Ian Hacking, The Taming of Chance, 6-8.
} 
inventions of modern time. ${ }^{5}$ In the tradition of Durkheim, what is normal is good and should be preserved. Society, however, usually veers away from this ideal course, thereby necessitating some form of restitution. Subsequently, we reorient ourselves in reference to this classification dubbed normal. Although other versions of normality may portray it in a teleological fashion (i.e. Comte, Galton), as an ultimate end to strive for, it is the former that is more pertinent to the current discussion of risk and uncertainty.

Normalcy helps establish a sense of what is right by introducing the potential for an objective average. Measured against a referential infrastructure, it is possible to ascertain the condition of development and judge it normatively as being right or wrong. Risk analysis is attune to Durkheim's "functionalism" as it divides units of analysis into interdependent sectors for the process of ordering a system. Rules help structure relationships between agents in such systems by addressing deviant behaviour and indicating the corrective path back towards normalcy/status quo. Though keep in mind that Durkheim would denounce the "impoverished and abstract character of homo economicus" central to risk analysis as pure fiction. ${ }^{6}$ Yet, replacing economic theory with a sociology of knowledge, as he intended, is not ideal either as it still privileges the notion of a social totality operating in accordance with natural laws that the actor need not even be aware of. A preferred approach is to explore the heterogeneous justifications and critiques that allow us to think in terms of the categories of risk and uncertainty.

Herein lies the advantage of an analytics of government. How uncertainty is deployed in the connection between cognitive, moral and material issues related to the political economy of EMU is a question at the heart of this dissertation. Arguably, it is a

\footnotetext{
${ }^{5}$ Ian Hacking, The Taming of Chance, 169.

${ }^{6}$ Michel Callon, "Introduction: The Embeddedness of Economic Markets in Economics," in The Laws of Markets, ed. Michel Callon (Oxford: Blackwell Publishing, 1998), 51.
} 
problematic of convergence around normative fiscal anchors. Convergence and stability are intimately connected to notions of normalcy as the latter provides the conditions legitimising fiscal conduct. After all, EMU is in part about the convergence of diverse European economies into one common market with a single currency. ${ }^{7}$ With this in mind, alternative explanations and methods emphasise different factors in their efforts to explain the SGP crisis and its broader ramifications for EMU governance. The above three schools of thought are investigated to determine the convincibility and tenacity of their claims in this regard. The intention is not to test these theories per se but assess their explanatory currency as it concerns the construction and regulation of a novel fiscal-monetary space.

For this purpose, I survey the competing IR literature in order to decipher the quality of its contributions to understanding the current problematic. Intergovernmentalism, constructivism and a post-Marxist critical political economy may offer commentary on issues such as geopolitical activity or the power of norms, but they ultimately fail to either denaturalise EMU or problematise the shift in modes of regulation precipitated by the Ecofin crisis. Nevertheless, there is a common thread running throughout their work; namely normalcy. All these theoretical positions revert to normative claims about EMU, which they equate with being "right." They may not subscribe exactly to Durkheim's functional division of labour but some semblance of normality pervades their scholarship. Here Hacking is correct to pronounce that normalcy is a fundamental ideology that has captured imaginations in numerous disciplines. It has been widely adopted in multifarious ways by diverging perspectives to account for control in social phenomena. Conventional IR theories demonstrate this point.

\footnotetext{
${ }^{7}$ Kenneth Dyson, "The First Decade," in The Euro at 10: Europeanization, Power, and Convergence, ed. Kenneth Dyson (New York: Oxford University Press, 2008), 19.
} 
I introduce their respective arguments and proceed to explain how competing approaches provide an inadequate conceptualisation and explanation of the problematic itself. The SGP crisis is the fundamental juncture that precipitated the transition to uncertainty-based governance. Without a proper understanding of this empirical puzzle, potential analysis is undermined. Unfortunately, opposing thinkers fail to appreciate the regulatory capacity through which uncertainty is delivered. We are given weak explanations of the operational dimension of constructing and governing EMU. Moreover, these accounts appear inattentive to the shift in modes of governance in the aftermath of the SGP crisis and how this impacts fiscal conduct and the legitimisation of various forms of power. Mainstream theories often fail to adequately explicate how these multiple power systems function to create EMU. Without this line of investigation, however, we are limited in our knowledge of the political, economic and social arrangements animating European integration. Unfortunately, conventional accounts continue to rely on old approaches that fail to appreciate this changing problematic of EMU governance by simply applying dated categories and methods to what is, arguably, the construction of a novel fiscal-monetary space.

Such omissions lead to a portrayal of EMU as a naturally pre-existing phenomenon grounded on false dichotomies and a linear history. Conventional theories do not, and often cannot, explain how the differentiated assessment of SGP statutes problematises a changing governmental perception of EMU management. To gain a greater appreciation for the changing logics underpinning this spatial-temporal order, which privilege the (re)politicisation of EMU governance, we must first identify the deficiencies present in prevailing academic currents. Once we are cognisant of how these theories misrepresent 
several of the principal matters in the debate about the SGP, and governance more broadly speaking, we can introduce a more convincing account in the form of governmentality. A comparative normality provides an enhanced and more comprehensive understanding of how power politics shapes, and is in turn influenced, by monetary and fiscal relations in the construction EMU.

When discussing economic and monetary integration, one expects to locate a fair amount of conventional economic analysis in the literature. This holds true for EMU where monetary economists have espoused an assortment of explanations dealing with the demise of the SGP. Most of the growing literature on monetary policy and international monetary relations focuses on government choices about central bank independence and fixed exchange rates. ${ }^{8}$ This tacitly takes the neoclassical economic paradigm as a constant in international and comparative political economy. Governments adopt policies attractive to international investors - low inflation, balanced budgets and a strong and stable exchange rate, regardless of the consequences for employment, growth and income distribution or the preferences of party politics regardless of regime type or economic development of the country in question. Yet, as I have explained, the SGP crisis is the culmination of Member States contravening several of these premises in order to accommodate their national demands through deficit financing.

Other economic propositions reply on "static models with $n$ asymmetric countries. ${ }^{99}$ Whereas others still concentrate on particular economic events, such as shocks,

\footnotetext{
${ }^{8}$ David Leblang, "To Devalue or to Defend? The Political Economy of Exchange Rate Policy," International Studies Quarterly 47 (2003): 533-60; Joseph Stiglitz and Bruce Greenwald, Towards a New Paradigm in Monetary Economics (Cambridge: Cambridge University Press, 2003).

${ }^{9}$ Avanish Dixit and Luisa Lambertini, "Symbiosis of Monetary and Fiscal Policies in a Monetary Union," Journal of International Economics 6 (2003): 235-47.
} 
applying quantitative abstract modeling in an effort to extrapolate an explanation. ${ }^{10}$ What connects these contributions is the high level of abstraction and hypotheses based on possible, but not necessarily probable, premises. Advancing complicated equations, models and graphs to justify their claims, these economists divorce the economy from its ideological, cultural and political practices of signification. Their predictions rest on numerous assumptions that are seldom problematised but readily transposed from one context to another. In sum, the value-added of their investigations is limited in helping understand the current problematic. Governance is more than a set of formulas and cannot be arbitrarily separated from its historical context. This is why such theories are omitted from this dissertation.

\subsection{Problematic Conceptualisations (pun intended)}

The asymmetric application of SGP statutes in 2003 is at the heart of the crisis in governance under study. As I have outlined in the preceding chapters, this puzzle has produced and revealed serious ideological, conceptual, and institutional inconsistencies in the European fiscal framework. To varying degrees all of the competing paradigms neglect to recognise some combination of these contrarieties in their assessments of the problematic. This stems from three primary reasons which form the basis of my critique in this section. The first is a reliance on false dichotomies as a bedrock for their explanations of what happened. These include the contrived separation of the international/domestic, public/private, and subject/object into dualities with an a priori facticity. Failing to problematise agency and interests precludes the "recognition of the deeply discursive nature of the realms of politics and economics" and that all "knowledge is discursively

\footnotetext{
${ }^{10}$ Montserrat Ferre, "Should Fiscal Authorities Co-operate in a Monetary Union with Public Deficit Targets?" Journal of Common Market Studies 43, no.3 (2005): 539-50.
} 
mediated." ${ }^{11}$ My dissertation investigates what is often presented as universal or seemingly self-evident to reveal their politicised nature and truth telling capacities.

Such an approach flows into the second pillar of contestation, which addresses how power relations condition the very discursive constitution of agency and interests. The articulation and codification of power "in the hierarchized surveillance of the disciplines is not possessed as a thing or transferred as a property" but "it is the apparatus as a whole that produces 'power' and distributes individuals in this permanent and continuous field."12 Disciplinary and control forms, in the performativity of risk/uncertainty, are omitted in favour of an economistic conception of power as a commodity, an idea or some underlying logic divorced from the techniques of truth production themselves. I take issue with how such deficiencies handicap alternative expositions not only in their conceptualisation of the problematic but indeed of monetary and fiscal governance more generally.

Thirdly, the spatial-temporal element is markedly absent as the historical contingency of the SGP puzzle is dismissed. The SGP crisis, much like EMU, is a creature of its time and occupies multiple sites where conduct is contested. Nevertheless, competing understandings fail to capture this relative and variable nature. The subjectification and objectification of governance is incomplete, as inscription and performativity are virtually ignored. Compounded by the subject/object dichotomy, this argument disturbs the notion that studies are simply representational of an underlying reality. Here I allude to the "performativity of markets" that Callon and MacKenzie discuss. ${ }^{13}$ Problematising how

\footnotetext{
${ }^{11}$ Marieke de Goede, "Introduction: International Political Economy and the Promises of Poststructuralism," in International Political Economy and Poststructural Politics, ed. Marieke de Goede (New York: Palgrave Macmillan, 2006), 5.

${ }^{12}$ Michel Foucault, Discipline and Punish: the Birth of the Prison (New York: Vintage, 1979), 176-77.

${ }^{13}$ Donald MacKenzie, An Engine, Not a Camera (Cambridge, MT: The MIT Press, 2006), 16; Michel Callon, "Performative Economics," in Do Economists Make Markets? On the Performativity of Economics, ed. Donald MacKenzie, Fabian Muniesa, and Lucia Siu (Princeton: Princeton University Press, 2007), 31 1-57.
} 
identities and interests are constructed rather than understanding them as a priori and how socio-technical practices are organised rather than what reality they represent, provides us with a better understanding of how markets are continually negotiated. What is witnessed is a dialectic between the two competing logics of legitimacy and enterprise or the programmatic and operational elements of organisational life. The Stability and Growth Pact crisis reflects this tension. In order to preserve a semblance of control new modes of governance were introduced that are sensitive to the uncertainty implicit in economic affairs within the European plane as well as beyond.

\section{Liberal Intergovernmentalism: The Normative and Prescriptive}

There is no doubt that national idiosyncrasies underlie EMU and that sovereignty plays a considerable role in integration. As the prime movers behind EMU, Member States monopolise policy channels and the interstate bargaining that produces them. ${ }^{14}$ Intergovernmentalists contend that it was in such a major forum, namely the Ecofin Council, where France and Germany, being the traditional "motors" of Europe, delegated their political prerogatives to the rest of the EU. ${ }^{15}$ Initially, this body was set up so that national sovereignty would be protected from an unaccountable ECB and its growing hegemony, thereby granting the power to sanction exclusively to governments. "France wanted maximum discretion in applying sanctions for excessive deficits" and exercised this privilege, along with Germany, in November 2003. ${ }^{16}$

\footnotetext{
${ }^{14}$ Robert Gilpin, Global Political Economy (New Jersey: Princeton University Press, 2001).

${ }^{15}$ Paola Subacchi, "Reforming Economic Governance in Europe: Exploring the Road to Effective Coordination," International Affairs 81, no. 4 (2005): 741-55; Jakob De Haan et al, "Why the Stability and Growth Pact Failed?" International Finance 7, no. 2 (2004): 235-60.

${ }^{16}$ William M. Chandler, "German Influence in Shaping EMU: Still a Tamed Power?" in The Euro: European Integration Theory and Economic and Monetary Union, ed. Amy Verdun (Lanham, Md.: Rowman \& Littlefield Publishers, 2002), 211.
} 
What resulted is a conceptual quagmire, which illustrates how foolish it is to assume that members will obediently punish themselves. Lacking automatic penalties, the authors of the SGP do not have the collective will to enforce its statutes. Thus, they resort to the practice of "naming and shaming." But big states are less susceptible to peer pressure than their smaller neighbours. Quite often this debate is framed as a polarisation between two opposing poles, pitting supranationalists against intergovernmentalists. It is presented as a choice of either ceding more power to the European level or a matter of retaining ultimate authority within the nation-state. The Ecofin crisis is said to be exemplary of the latter.

For intergovernmentalism, and its various offshoots, the nation-state and sovereign power remain formidable forces in European economic and monetary integration. ${ }^{17}$ Their ambition is to resolve problems associated with economic interdependence while reasserting national sovereign power. EU institutional arrangements and decision-making procedures simply facilitate effective negotiations as these pertain to an order of material interests that are irreducible to ideational frames or discourses. The most fundamental of these are commercial interests. They trump geopolitical concerns and are presented as being exogenously given, ranked and transitive. ${ }^{18}$ Moravcsik posits that:

European integration resulted from a series of rational choices made by national leaders who consistently pursued economic interests- primarily the commercial interests of powerful economic producers and secondarily the macroeconomic preferences of ruling governmental coalitions- that evolved slowly in response to structural incentives in the global economy. When such interests converged,

\footnotetext{
${ }^{17}$ Andrew Moravcsik, The Choice for Europe: Social Purpose and State Power from Messina to Maastricht (Ithaca: Cornell University Press, 1998); Marco Buti and Lucio R. Pench, "Why Do Large Countries Flout the Stability Pact? And What Can Be Done About It?" Journal of Common Market Studies 42, no. 5 (2004).

${ }^{18}$ Hussein Kassim and Anand Menon, "The Principal-Agent Approach and the Study of the European Union: Promise Unfulfilled?" in The Political Economy of European Integration: Theory and Analysis, ed. Erik Jones and Amy Verdun (New York: Routledge, 2005), 44.
} 
integration advanced. ${ }^{19}$

Depending on the politico-economic weight attributed to certain ex ante preferences, EMU evolves in contested and discontinuous strides. It is the relative power of the unitary state that dictates the scope of its authority and the bargaining position it occupies in determining the scope and direction of integration. Institutional designs are thus a derivative of calculating, rational actors in the form of states. Supranational bodies, such as the Ecofin Council, help coordinate input into decision-making. This comprises the bedrock of the intergovernmentalist paradigm.

Charged as a state-centric ontology privileging a black box of agency and interest formation, IG retained the traditional realist adherence to a state-society duality.

Moravcsik, however, revised this by introducing a pluralistic view of society whereby domestic constituents perform cost-benefit analyses, the results of which are then aggregated and transferred by institutions as demands onto national governments. In this fashion domestic interests groups help define national interests. ${ }^{20}$ His "liberal" version of intergovernmentalism draws on economic public goods theory in addition to Robert Putnam's game theoretics.

Rooted soundly within neo-classical economics, Putnam proposes a model of twolevel games where "win-sets" are determined solely by domestic participants. In the first instance, at the national level, rational and risk-adverse actors vie to have their preferences actualised, operating under the constraints of "material scarcity, conflicting values, and

\footnotetext{
${ }^{19}$ Andrew Moravcsik, The Choice for Europe: Social Purpose and State Power from Messina to Maastricht, 3.

${ }^{20}$ Andrew Moravcsik, "Taking Preferences Seriously: A Liberal Theory of International Politics," International Organization 51, no.4 (1997): 516.
} 
variations in societal influence." ${ }^{21} \mathrm{Next}$, on the international stage, national governments seek to maximise their capacity to satisfy their dominant, domestic voices while simultaneously minimising the adverse effects of rival state policies. For Putnam, as well as Moravcsik, the probable win-set at the international level is the aggregate of all possible national agreements that would be successful. ${ }^{22}$ Because interests are exogenously given, ranked and transitive, they may be arrived at through rational positivistic methods. The probability of success may then be assigned a numerical value since risk is "codified as a calculable entity.,23

Three factors are said to determine the win-set size. These include international preferences and supporting coalitions, international institutions, and negotiator strategies. Here the "calculation involves trading off efficient collective decision making against the risk of being outvoted or overruled." ${ }^{24}$ Yet, the composition of the win-set, and thus the margin to manoeuvre, primarily reflects domestic interests, which are independent of any domestic or international political processes. Transnational groups may exert some influence on the domestic lobby but not on the negotiating position directly. Their role is marginal, restricted to supporting "supranational entrepreneurs" who are themselves quite weak relative to nation-states. ${ }^{25}$

Introducing the domestic actor back into the integration equation, Moravcsik provides a bottom-up liberal account of EMU that is both technical and functional. Derived from neofunctionalism and neoinstitutionalism, his liberal intergovernmentalism borrows

${ }^{21}$ Andrew Moravcsik, "Taking Preferences Seriously: A Liberal Theory of International Politics," 516.

${ }^{22}$ Robert Putnam, "Diplomacy and Domestic Politics," International Organization 42, no. 3 (1988): 440.

${ }^{23}$ Marieke de Goede, Virtue, Fortune, and Faith: A Genealogy of Finance (Minneapolis: University of Minnesota Press, 2005), 50.

${ }^{24}$ Hussein Kassim and Anand Menon, "The Principal-Agent Approach and the Study of the European Union: Promise Unfulfilled?" 44.

${ }^{25}$ Andrew Moravcsik, "A New Statecraft? Supranational Entrepreneurs and International Cooperation," International Organization 53, no. 2 (1999): 267-306. 
an emphasis placed on economic interests and interdependence from the former and the recognition of the facilitating role that international bodies play from the latter. ${ }^{26}$ Embedded within an "asymmetric power constellation," large states impose their domestically framed preferences onto their smaller counterparts. However, the mechanics of transmitting national preferences to the EU are more refined than a simple categorical imposition and submission of wills. A strategic dialogue is generated in order to ensure mutual cooperation regarding community objectives. Game theoretics claim that such mutual recognition and compliance are best achieved through a commitment to binding rules. In this manner, cooperation yields more Pareto efficient outcomes that what would otherwise degenerate into conflictual struggles. Without such conditions in place EMU is susceptible to national idiosyncrasies and the inconsistent fiscal policies they produce. Such is the case as the absence of monetary policy autonomy "has shifted the political bias towards fiscal expansion and has increased the risk of a 'free-rider' problem within the euro area." 27

Unfortunately, Moravcsik never applied his theory directly to the SGP crisis. His ideas, however, regarding the propensities of states have been borrowed to help explain how German and French diktats steer the agenda of the Ecofin Council. A noted concern is that those liberal intergovernmentalists who have tackled the current problematic tend to concentrate disproportionately on the economic dimension of the puzzle without seriously engaging in the sovereignty argument. The nation-state is recognised as an actor but only one amongst many. Without contesting sovereignty, subjectivity or the hierarchies they

\footnotetext{
${ }^{26}$ Robert Gilpin, Global Political Economy, 354.

${ }^{27}$ Paolo Subacchi, "Reforming Economic Governance in Europe," 746.
} 
imply, such analyses merely reproduce essentialist binaries. I shall return to this critique shortly.

Given the economic nature of EMU, it is impossible to divorce an investigation of the SGP from the economics discipline. Nor is it necessary. Hence, the numerous publications and opinions from leading economists like Andrew Hughes-Hallett. ${ }^{28}$ Conversely, certain strands of IG, specifically the liberal version, accomplish this feat and often divest themselves of the political element in their assessments. Focusing predominantly on macroeconomic variables while remaining silent on subsequent political developments impairs their contributions. It marginalises their supposed "prime mover" by minimising the state's explanatory value. More significantly, it depoliticises monetary and fiscal governance by overemphasising economic criteria at the expense of political and social forces. Nevertheless, it is worth exploring IG in order to extract any potential insights into the SGP puzzle. For this task, I begin with the basics of bargaining; namely rules.

Rules form the basis of the treaties and protocols that Member States sign. These are essentially contractual obligations stipulating how they will behave given certain variables in a particular context. Underpinning the fiscal philosophy of the SGP, according to Kopits, rules are defined as a "permanent constraint on fiscal policy, expressed in terms of a summary indicator of fiscal performance, such as the government budget deficit, borrowing, debt, or a major component thereof." 29 Permanence, however, is a hotly contested term that is often anything but permanent. In this regard, Verdun and Heipertz are

\footnotetext{
${ }^{28}$ Andrew Hughes-Hallett, "Sustainable Fiscal Policies and Budgetary Risk under Alternative Monetary Policy Arrangements," Economic Change and Restructuring 41, no. 1 (2008): 1-28.

${ }^{29}$ George Kopits, "Fiscal Rules: Useful Policy Framework of Unnecessary Ornament?" Banca d'Italia (2001): 59 .
} 
correct in their assessment of the SGP as a politicised "contract" that aims for fiscal austerity. ${ }^{30}$ The legality of such agreements does not supersede the power of the state to renege on its promises and breach the contract (i.e. SGP crisis).

Without binding regulations, EMU would be paralysed by its overt susceptibility to national idiosyncrasies. To achieve consensus in the absence of a framework would thus require an effort of herculean proportions and deep concessions to be made by most parties. Incredulous of such idealism, the Pact still manages to entice some convergence among national policies. Simultaneously, this arrangement produces a conceptual quagmire in the attempt to parsimoniously manage EMU integration. The institutionalisation of monetary policy at the EU level, without a corresponding development in the fiscal realm, creates a paradox. Some degree of coordination and compliance are essential for maintaining the integrity of a common monetary union. But the absence of fiscal federalism demands that budgetary adjustment remain an available instrument for Member States to employ in the face of market shocks. Rules are devised that are known to be broken. This undermines a fiscal philosophy endorsing rule-based rather than discretionary macroeconomic stabilisation. ${ }^{31}$ After all, unbridled discretion is perceived as pre-empting an inflationary bias. Yet rules that lack credibility may be just as guilty. Such is the dilemma of transposing a monetary infrastructure onto a fragmented landscape of fiscal regimes. It necessitates a broader understanding of EMU governance beyond the purely technical and functional. I have identified this conundrum in preceding

\footnotetext{
${ }^{30}$ Martin Heipertz and Amy Verdun, "The Dog that Would Never Bite? What We Can Learn from the Origins of the Stability and Growth Pact," Journal of European Public Policy 11, no. 5 (2004): 765-80.

${ }^{31}$ Deborah Mabbett and Waltraud Schelkle, "Bringing Macroeconomics Back into the Political Economy of Reform: the Lisbon Agenda and the 'Fiscal Philosophy' of EMU," Journal of Common Market Studies 45, no. 1 (2007): 82.
} 
paragraphs and it shall continue to contribute to my conceptual critique throughout the dissertation.

Institutionalised inter-state bargaining in a forum of open method coordination is designed to overcome the problem of collective fiscal management. IG recognises the need to balance the egotistical agendas of nation-states with common European objectives. For this effect, soft laws are introduced that rely on the "self-commitment by the Member States, peer review and benchmarking, placing emphasis on policy learning and consensus building." ${ }^{32}$ Without the binding obligations and the automatic sanctions of hard law, these tactics of macroeconomic governance are presented as a compromise between subjugating states and allowing governments to retain a certain degree of autonomy and control over the fiscal process. In their analysis of the SGP problematic, intergovernmentalists explain that power politics skews this supposed asymmetry thereby undermining the entire fiscal framework. Such a "gentleman's agreement," as the SGP arguably is, was essentially terminated by German and French demands for special recognition. ${ }^{33}$

Coupled with this is the contention that the efficacy of "naming and shaming" into compliance those that Otmar Issing refers to as "fiscal sinners" diminishes with the size of the country. ${ }^{34}$ Reputation is not as imperative for the likes of Germany or France since they already possess clout by virtue of their relative size. Together as a coalition, the imposition of their collective will is only advanced by a punitive system that operates

\footnotetext{
${ }^{32}$ Fabian Amtenbrink and Jakob De Haan, "Economic Governance in the European Union: Fiscal Policy Discipline versus Flexibility," Common Market Law Review 40 (2003): 1078.

${ }^{33}$ Martin Heipertz and Amy Verdun, "The Dog that Would Never Bite? What We Can Learn from the Origins of the Stability and Growth Pact," 119.

${ }^{34}$ Michele Chang, "Reforming the Stability and Growth Pact: Size and Influence in EMU Policymaking," Journal of European Integration 28, no. 1 (2006): 118.
} 
according to a qualified majority vote. Thus, larger Member States are pronounced as virtually having dictatorial powers in their relations with their smaller neighbours and international institutions. What this assertion ignores is that, for the most part, the "SGP has constrained governments...via the 'soft' pressures of peer esteem and calling into question of their domestic reputation for competence (original italics). ${ }^{, 35}$ The SGP crisis is an anomaly in the sense that convergence was accomplished prior to 2003 and fiscal discipline was mostly maintained.

Without doubt, the magnitude of economic activity attributed to larger members cannot be ignored as trivial. Understanding the SGP problematic as a renegotiated contract, as proposed by Schure and Verdun, alerts us to the disciplinary potential of such a mechanism and how it migrated from the corporate sector to infiltrate international relations. ${ }^{36}$ Nevertheless, the collapse of such an agreement cannot simply be explained by an arbitrary renunciation as states are rational and calculating. In particular, the smaller members would forecast and accommodate for the risk of defection and be deterred from committing to such an OMC, throwing European integration into peril. Why should they be subject to a higher standard while larger members violate the SGP with impunity? I shall return this point further in my critique.

Here I wish to convey that intergovernmentalists may be conscious of this contingency. This may explain why they supplement the contractual argument with an attack on the economic orthodoxy of the Pact to introduce national political factors as well as geopolitics. Reducing EMU to liberal economic contracts based on the legal

\footnotetext{
${ }^{35}$ Iain Begg and Waltraud Schelkle, "The Pact is Dead: Long Live the Pact," National Economic Institute 189 (2004): 88.

${ }^{36}$ Paul Schure and Amy Verdun, "States and the Exercise of Power in the New European Union," in Political and Economic Consequences of Economic and Monetary Union: Taking Stock of the First Eight Years, ed. Amy Verdun (New York: Nova Science Publishers, 2007), 74.
} 
obligations of an abstract individual neglects the political environment where fiscal conduct occurs. Such disregard for the non-economic motives of heterogeneous entities like states diminishes liberal intergovernmentalism's explanatory capital as it divorces practice from its embedded political realities.

Another line of argumentation forwarded by IG in its attempt to understand the SGP problematic is the tension between two competing strands of logic behind EMU. In fact, the new monetarist orthodoxy, which provides the economic rationale for the SGP, actually contradicts the neo-Keynesian demand-management initiatives central to realising the sovereign aspirations of Member States. In addition to this conflict, there is the shared perception by economists that the fundamentals of the SGP are inherently flawed. Respected scholars have criticised the Pact for its simplicity and rigidity in the prevention of excessive deficits and for any possible negative spillover into the monetary domain. ${ }^{37}$ Governments are stripped of the flexibility to institute counter-cyclical budgetary policies in the advent of a market correction by the Pact's strict rules. Handcuffing states in an environment where expansionary policies act as automatic stabilisers can actually intensify recessionary pressures. Such a regulatory bias towards deficits creates its own operational asymmetry together with "risks that may be larger than the risks of default and bailouts stressed by the proponents of rules." 38

When the eurozone experienced an economic downturn in 2002, it was apparent that the medium-term budgetary objective of close-to-balance or in surplus could not be maintained without severe unemployment and deflationary consequences. German officials rejected such costs, which essentially entailed sacrificing their national interests

${ }^{37}$ Barry Eichengreen and Charles Wyplosz, "Instability Pact?" European Economic Perspectives 48 (1998); Willem Hendrik Buiter, "How to Reform the Stability and Growth Pact?" Central Banking 13 (2003): 49-58. ${ }^{38}$ Paul de Grauwe, Economics of Monetary Union (New York: Oxford University Press, 2007), 237. 
in favour of some arbitrary reference criteria. The inference to be drawn is that if the underlying assumptions behind the SGP were economically sound (i.e. compatible with state objectives) then they would be more sustainable. However, in the absence of such fiscal flexibility combined with an excessive emphasis placed on deficits rather than targeting aggregate budgetary positions, IG attributes the crisis in European macroeconomic stabilisation to an erroneous preventative arm that subjected national governments to misguided demands. ${ }^{39}$

Another salvo fired at the economic haul of the SGP was the charge that the medium-term budgetary positions of Member States were too close to the reference value of 3 percent. ${ }^{40}$ Should governments have consolidated their finances in the "good times" of Stage II, when growth was rapid, they would have had more room to manoeuvre when the market correction hit. Instead, in some states fiscal consolidation was relaxed in the economic upturn following Stage II. In others, counter-cyclical policies aimed at attaining a position of CTBOIS (Council Resolution No 1466/97) were virtually abandoned. Tax cuts which proved popular with national electorates were partly blamed for the relaxed fiscal positions.

As the economic slowdown became more prolonged than was originally forecast, the French and German deficits reached 4.1 percent and 4.0 percent respectively in 2003 and, together with Portugal, triggered the EDP. The current emphasis placed on exploiting good times in the reformed Pact reflects this lesson and the need to be more vigilant in anticipating and preparing the treasury against potential economic slowdowns. However, rather than a flexibility problem it was deemed a structural issue as the

\footnotetext{
${ }^{39}$ Iain Begg and Waltraud Schelkle, "The Pact is Dead: Long Live the Pact," 92.

${ }^{40}$ Paola Subacchi, "Reforming Economic Governance in Europe," 749.
} 
CTBOIS criteria neglected divergent budgetary positions and synchronicities with different susceptibilities to economic shocks. ${ }^{41} \mathrm{~A}$ "one-size-fits-all" policy only served to increase the vulnerability of states violating the prescribed rules.

Poor economic orthodoxy may have been the culprit but the proliferation of noncompliance was asymmetrical, with larger states (e.g. Germany, France) reversing their approach and free-riding on the efforts of smaller members (e.g. Belgium, Finland). Noticeable is the gulf that ensued between the big and small states as the former were unwilling to reform their fiscal positions in order to maintain an underlying balance. ${ }^{42}$

The most obvious display of such asymmetrical power politics may be the case of Portugal, which was subject to the EDP in 2003 but was compelled to correct its budgetary position through substantial austerity measures. For IG, holding the EDP in abeyance against Germany and France simply reaffirms the progressive loss of credibility the Pact endured as larger states shunned its rules at their own discretion. Discrepancies between fiscal projections and actual outcomes are indicative of the bias large members have had to have in order to underestimate their budgetary shortfalls. Buti and Pench note that:

three largest countries in the euro area appear largely to blame for the credibility gap affecting stability programmes, as their fiscal projections can be shown to suffer a significant bias to under-predict actual deficits. ${ }^{43}$

This paradox in behaviour undermined the preventative arm while simultaneously reasserting the sovereign power of Member States to cede and withdraw authority granted to the European level.

\footnotetext{
${ }^{41}$ Paola Subacchi, "Reforming Economic Governance in Europe," 749.

${ }^{42}$ Anthony Annett, "Enforcement and the Stability and Growth Pact: How Fiscal Policy Did and Did Not Change under Europe's Fiscal Framework," IMF Working Paper 116 (2006): 8.

${ }^{43}$ Marco Buti and Lucio R. Pench, "Why Do Large Countries Flout the Stability Pact? And What Can Be Done About It?" Journal of Common Market Studies 42, no. 5 (2004): 1026.
} 
Acknowledging the Commission's observation that France and Germany were in breach of their treaty obligations, Ecofin nevertheless rejected adopting its recommendations to impose sanctions. Instead, "conclusions" were issued appearing to favour a small qualified majority vote orchestrated by Germany and France, together in conjunction with the usual suspects; namely Italy, Greece, Portugal but also Luxembourg, Belgium, and Ireland. ${ }^{44}$ This verdict would eventually be annulled by the ECJ in 2004. Nevertheless, liberal intergovernmentalists point to the manner in which larger members impose their preferences on community institutions as well as their smaller neighbours. Such manipulation of agreed protocol is not an anomaly restricted to November 2003.

National interests are identified as the contributing factor that aborted the issuance of an "early warning" to Germany and Portugal in 2001 and again to Germany in early 2002. In the latter case, Schröder was facing the electorate in a national campaign. Again, exploiting its relative bargaining power, Germany managed to convince enough skeptics to waive this SGP early indication of fiscal misdemeanour. But weakening SGP enforcement mechanisms further corrupted the integrity of the fiscal framework. Embedded within a post-9/11 environment, where fiscal discipline was not considered a priority, Germany's complaints fell on accordant ears. Geopolitics helped reinforce national objectives but with consequential effects on Community standards.

\section{Liberal Intergovernmentalism: The Critique}

Liberal intergovernmentalist tendencies to simply reintroduce a pre-packaged state and reduce interactions to a set of abstract models and games blind them to how the problem

\footnotetext{
${ }^{44}$ Martin Heipertz and Amy Verdun, "The Dog that Would Never Bite? Origins, Crisis and Reform of Europe's Stability and Growth Pact," in EMU Rules: The Political and Economic Consequences of European Monetary Integration, ed. Francisco Torres, Amy Verdun and Hubert Zimmermann (Baden-Baden: Nomos, 2006), 123.
} 
of EMU management changes as a result of the differentiated assessments of SGP statutes. Political motives and modes of representation are relegated a minor role while economic interdependence is presented as the principal trigger underpinning integration. Obviously, commerce is a fundamental factor behind EMU but not everything can be attributed to economic incentives alone. National security measures cannot be compromised for commercial gains; at least not according to state-centric realists. By making economics the lowest common denominator, liberal intergovernmentalists retain a dialectical form of sovereignty without being sensitive to the impact that such a position actually has on national security itself. The very state-centric ontology which they advocate gets convoluted as politics, not to mention society, become excluded and subservient to liberal economic theory.

Territorial lines are demarcated by the traditional Westphalian state system. EMU, however, has developed beyond these confines while simultaneously preserving a connection to them. Nevertheless, it is still identified as possessing spatial and temporal properties. In this emerging space, power is exercised at a variety of sites with multilayered boundaries. By investigating mechanisms that exert a disciplinary force in the normalisation of subjectivities, a relational conception of power becomes visible which reflects the unfixity of not only EMU's micro-social, but also "emergent and provisional macrosocial," order. ${ }^{45}$ In turn, the analysis can now focus on governing spaces rather than just territories.

Even more distressing is the absence of a genuine interest theory. Prior political agency implies that preferences are exogenous to the model. When domestic groups are

${ }^{45}$ Bob Jessop and Ngai-Ling Sum, "Towards a Cultural International Political Economy: Poststructuralism and the Italian School," in International Political Economy and Poststructural Politics, ed. Marieke de Goede (New York: Palgrave Macmillan, 2006), 165. 
acknowledged, liberal intergovernmentalists present abstract preferences and cannot explain how these interests change allowing a player, such as Germany, to commit the very offence that it set out to avoid. Without any serious discussion about interest or identity formation, deciphering who the beneficiaries of government are becomes an arduous exercise. Who do EMU technologies of government, such as the SGP, and the myths of control they perpetuate really serve? In an attempt to answer this question the state is erected as a "mythical abstraction," as a homo economicus, fulfilling the functional role of an actor. ${ }^{46}$

Europe, however, is not composed of abstract hypotheticals operating according to homogenous and static laws. Governments act on behalf of particular actors whose interests and identities are constituted and transformed as they struggle for power. Conflicts akin to these eventually disrupted the authority of the new monetarist doctrine but the power of representation is absent from IG literature. Nor is sovereign power the sole force of consequence in the definition of the boundaries and hierarchies that constitute EMU and Europe more broadly. By adhering to such rigid doctrine, intergovernmentalists fail to acknowledge what Rose and Miller refer to as the "de-governmentalization of the state ${ }^{, 47}$ or, as Jessop notes, the "de-statification of politics." ${ }^{48}$ Thus, conceptualisations of governance are hindered, which handicaps possible explanations of fiscal and monetary conduct.

\footnotetext{
${ }^{46}$ Nikolas Rose and Peter Miller, "Political Power beyond the State," British Journal of Sociology 43, no. 2 (1992): 173.

${ }^{47}$ Nikolas Rose and Peter Miller, Governing the Present: Administrating Economic, Social and Personal Life (Malden, MA: Polity Press, 2008).

${ }^{48}$ Bob Jessop, The Future of the Capitalist State (Cambridge: Polity Press, 2002).
} 
Opposition to the fixed identities and boundaries of state sovereignty opens the door to a "politics of deterritorialized flows" and a politics of difference. ${ }^{49}$ This facilitates the movement away from a purely legalistic conception of power as a commodity functioning within a system of formal state institutions to a more fluid and hybrid understanding of governance. At the same time, we become more attuned to how diverse forms of power are contested in the production of EMU subjectivities and the constitution of this emerging fiscal-monetary space as a site of its own economy. It draws our attention to how power "is attached to social positions that are relationally defined" rather than exogenously given. ${ }^{50}$

Freed from the confines of institutions and macrostructures it is possible to move beyond simply discussing sovereign forms of power to explore particular technologies of power. Discipline and control are introduced alongside sovereignty. Leverage is exerted through the governmental modality of uncertainty as managing responsibility becomes a more endogenous act dependent on the production of truth. Knowledge, including subjectivity, is produced through the legitimation of truth claims, which is much more unstable and multifarious than intergovernmentalists present. My genealogy disturbs this representation of EMU as coherent and self-perpetuating in the effort to account for the conditions that configure it as a regulatory space. Having addressed some of the more general inadequacies associated with this school of thought, I now tackle its poor conceptualisation of the SGP problematic.

As already alluded to in the above paragraphs, the ontology of IG theory is riddled with false dichotomies. Failing to problematise agency and interests, IG must rely

\footnotetext{
${ }^{49}$ Michael Hardt and Antonio Negri, Empire (Cambridge: Harvard University Press, 2000), 142.

${ }^{50}$ Colin Wight, Agents, Structures and International Relations (New York: Cambridge University Press, 2006), 152.
} 
on predetermined categories in order to explain virtually everything, including the SGP problematic. Beginning with a contrived distinction between state and societal relations a wedge is driven between the formal, national entities that possess a "monopoly on the legitimate use of force in a demarcated territory" and domestic interest groups. ${ }^{51}$ As an ensemble of governmental institutions, the state is equipped with certain capacities and resources not as a result of societal contestation for power but rather reflects a naturalised system of nation-states. Interaction between the two is essentially non-existent as the state and society are divorced into separate realms of existence each operating according a predetermined and unique logic. But the powers of the state depend not only on the very system of nation-states but also on:

its encompassing political system, the strategic links among state officials and other political forces, as well as the complex web of interdependence and social networks linking the state system to its wider environment. ${ }^{52}$

As Colin Wight contends, the state is constituted within society and therefore attempts at defining it a priori outside this social and cultural environment are inattentive to how boundaries, such as those established by uncertainty, are derived from practices and technologies of rule which are both endogenous and exogenous to the state. ${ }^{53}$

Of course, Moravcsik attempts to remedy this duality by introducing national institutions that communicate aggregated domestic demands to the state level. Nevertheless, his analysis of these organisations is vague and underdeveloped as states continue to occupy the preeminent role. What remains is an atomistic conception of

\footnotetext{
${ }^{51}$ Nikolas Rose, Powers of Freedom (New York: Cambridge University Press, 1999), 1.

${ }^{52}$ Colin Wight, Agents, Structures and International Relations, 222.

${ }^{53}$ Colin Wight, Agents, Structures and International Relations, 224.
} 
society as a "marketplace" of perpetual cost-benefit analyses. ${ }^{54}$ Such reductionism neglects how political and economic objects are socially constructed and embedded in a historically contingent and "institutionally-mediated condensation of a changing balance of forces." ${ }^{55}$ Yet, this is what IG succumbs to as it privilege a false subject/object dichotomy. Its model of EMU divorces agents, being nation states, from the analytical and discursive environment in which they are embedded. Such a move neglects the performativity entailed in the constitution of EMU subjectivities, which are defined and understood through the language of risk and uncertainty. These concepts are fundamental to the articulation of specific versions of the European project and their actualisation.

Neither is there any discussion of the role that technology plays in the transnationalisation of governance. How states lose authority to markets or International Financial Institutions (IFI) because of changes in technology and the operational risks this introduces for governance are completely lacking here. Instead, all that we are presented with is a static conceptual model of agency, interests and power that fails to provide any new institutional answers aside from more formal, interstate bargaining. But without an appreciation for how the technological aspects of government (i.e. benchmarking, auditing) are informed by risk and uncertainty, it is difficult to explain the SGP problematic as an object of government. These are the concepts underlying analysis and central to the legitimisation of EMU as a particular body of knowledge and regulatory system.

Simply adding up actions in an arithmetical fashion is a poor indicator of dynamic social relations. The IG approach ignores the performativity involved in rendering a

\footnotetext{
${ }^{54}$ Bastiaan van Apeldoorn, Transnational Capitalism and the Struggle over European Integration (New York: Routledge, 2002), 40.

${ }^{55}$ Bob Jessop and Ngai-Ling Sum, "Towards a Cultural International Political Economy: Poststructuralism and the Italian School," 159.
} 
social entity into being. Francesco Guala notes that "social properties are extrinsic properties of a special kind: they depend on the context, and in particular on what other human beings know, believe, or in a single word intend about the entity in question (original italics). ${ }^{, 56}$ Asserting that the SGP is merely a negotiated contract anchored in a series of static, economic cost-benefit analyses removes the freedom associated with "intentionality" from the explanation and replaces it with fixed tendencies. Yet, these tendencies are themselves conditioned by their environment and not objectively ubiquitous phenomena that pervade every sphere of existence. In order to properly understand a relationship, it is necessary to explain how its articulation is produced. Ceteris paribus clauses seem to fulfill this function for IG but only in an ex post facto fashion. Moreover, these stipulations actually construct a separate reality with an a priori facticity by the new boundaries of existence that they devise. What we are presented with is not the SGP crisis but a fictitious, hypothetical universe since many of these stipulations are fabricated for the purpose of theoretical parsimony.

Intergovernmentalists also fail to acknowledge the role that transnational interests play in EMU. These are groups that participate at once in domestic and international arenas (e.g. multinational firms, transnational advocacy groups). By only recognising their influence in situations where domestic interests are incapable of effective organisation and restricting their impact on actual negotiations, IG omits to appreciate the reach and scope of these non-state actors.

\footnotetext{
${ }^{56}$ Francesco Guala, "How to Do Things with Experimental Economics," in Do Economists Make Markets? On the Performativity of Economics, ed. Donald MacKenzie, Fabian Muniesa, and Lucia Siu (Princeton: Princeton University Press, 2007), 134.
} 
Take the European Round Table of Industrialists (ERT) for example. Providing a common stage for forty-five chief executives and chairmen from major European firms, ERT identifies issues critical for economic competitiveness and communicates policy proposals to governments. Considering itself:

neither a business lobby group nor a think tank, ERT has consistently sought to wake up policy makers to looming problems and to sow the seeds of ideas for their solution. The quality of its ideas and proposals have steadily acquired a reputation for first-rate analysis and intelligent argument. ${ }^{57}$

Through it reports and high-level networking, ERT has influenced the direction of European policy. Furthermore, to "claim that domestic social groups matter but transnational interests do not misses that point that, progressively, these two groups are one and the same. ${ }^{, 58}$ In an increasingly globalised world, domestic interests often operate in multiple jurisdictions aside from their own.

ERT has waded into the debate on a common monetary union, supporting the project as a necessary foundation for the Single Market and the reduction in the costs of business. When fiscal profligacy came to dominate the agenda, ERT was vocal about the constraining role that the SGP plays regarding matters such as pension reform. Common benchmarks should be improved in addition to the monitoring of fiscal activity, perhaps even through a supranational authority. However, governments are faced with arduous decisions and will deviate from established fiscal rules given sufficient pressure; pressure that may be exerted by a wide range of non-state actors, including transnational groups.

\footnotetext{
${ }^{57}$ European Round Table of Industrialists, "ERT Milestones and Chairmen," ERT, available from http://www.ert.be/ert_milestones_and_its_chairmen.aspx.

${ }^{58}$ Maria Green Cowles, "Non-State Actors and False Dichotomies: Reviewing IR/IPE Approaches to European Integration," in The Political Economy of European Integration: Theory and Analysis, ed. Erik Jones and Amy Verdun (New York: Routledge, 2005), 27.
} 
ERT is sensitive to the argument that "political constraints are difficult to overcome."59 Yet, adhering to a false dichotomy between public versus private agency blinds IG to the agenda setting capacity of transnational interests and the entire governmental structure designed around them. Even when non-state actors are afforded some authority, the state is not displaced from the "core of the regulative ideal of interpretation." diminishes its own explanatory capacity and value in regards to the SGP problematic and EMU more broadly.

Professing the "collapse of a gentlemen's agreement" does not shed light on the problematic, aside from providing a synonym in place of the "SGP crisis." In fact, such language actually conflates the private, domestic citizen with a public, international nation-state by referring to the latter using terms commonly associated with the former. That being said, this section is not the place to debate whether epistemological questions supersede ontological considerations. Although intergovernmentalists are of the conviction that the inverse is true (i.e. ontology is chronologically first), I am bracketing these issues in order to understand and explain how the process of constructing a European fiscal-monetary space is a relationship between boundary objects, such as uncertainty, and the material elements of social existence. Ontology is vital and that is why my methodology - being a critical genealogy - diagnoses the very regulatory practices that constitute EMU to establish the materiality of discourse.

\footnotetext{
${ }^{59}$ European Round Table of Industrialists, "Summary of Discussion" (presented at ERT High Level Meeting on Pension Reform, Brussels, Belgium, October 31, 2001).

${ }^{60}$ David Campbell, "Political Prosaics, Transversal Politics," in Challenging Boundaries, ed. Michael J. Shapiro and Hayward R. Alker (Minneapolis: University of Minnesota Press, 1996), 10.
} 
Embedded in these practices, however, is a "history of governmental reason" that is contingent on time and place rather than a priori.$^{61}$ Tracing the alignment of economic conduct with socio-political ambitions, I provide a more comprehensive understanding of the conditions that structure EMU existence than located in conventional IR theories. Here is where the epistemological significance lies as what is known affects what will become. This should not be misinterpreted to mean that anything can be willed into existence. Rather that the governance structures and mechanism of EMU are represented as thinkable within specific mentalities and articulated through discourses, which form the basis of our knowledge.

Even more troubling is that intergovernmentalists privilege the nation-state as being the normatively superior centre. In the process of elevating the state, they promote the facticity of a subject/object duality. There is no mutual constitution of subjects and objects. IG dichotomies "tend to obscure relations of interdependence and embeddedness and marginalize issues of identity and subjectivity." 62 Indeed, this is compounded by the economic reductionism that is employed in regards to the SGP problematic. Only an abstract homo economicus behaves in strict accordance with the laws set out by liberal IG accounts. As I noted above, this is a fictitious actor that is often at variance with reality. Binary oppositions exist that are ignored in favour of parsimonious conclusions in a hypothetical realm. The poor economic orthodoxy argument is telling of this dilemma. Here liberal economic virtues of balance budgets, low inflation and a strong and stable exchange rate, to name but a few, are exalted and prioritised over social, political, and

\footnotetext{
${ }^{61}$ Michel Foucault, Security, Territory, Population: Lectures at the College de France, 1977-78, trans. Graham Burchell Basingstoke (New York: Palgrave Macmillan, 2007), 354.

${ }^{62}$ V. Spike Peterson, "Getting Real: The Necessity of Critical Poststructuralism in Global Political Economy," in International Political Economy and Poststructural Politics, ed. Marieke de Goede (New York: Palgrave Macmillan, 2006), 124.
} 
cultural positions. A hierarchy is formed, which only reinforces the false dichotomy between the subjects and objects of governance.

All of this conduct is summarised through the language of price. Be it in euros or dollars or any other denomination, the principal communicative medium is price. Obviously, these are economic matters so price is relevant. Yet, irrespective of the argument that price is "the ultimate dimension, it is not an articulate language" but one that profiles conduct ex post facto. ${ }^{63}$ Its composition reflects the sum of a plethora of relations and the functions of other variables, whose visibility are noticeably absent from the IG calculations pointing to the SGP's demise. Valuation itself is an intersubjective process that cannot be reduced to a single numerical figure if the intent is to understand its multifarious dimensions. Yet, this is exactly what IG theory does.

National institutions and the political pressures that IG highlights as contributing to the SGP debacle are also beyond such narrow categorisations. The early warning system failed to be implemented in part because of the threat of potential political repercussions, which gained resonance given their roots in symbolic traditions and myths. A poor reputation for a nation priding itself on sound macroeconomic leadership would cast doubt on whether the Schröder government was indeed fit to manage the German economy, especially amongst its electorate in a year when they were heading to the polls.

Next, in order for IG liberal economic methodology and laws to be credible, "an impartial, consistent and competent enforcement mechanism" is necessary. ${ }^{64}$ Otherwise, the assumptions underpinning this economic doctrine would be undermined as they require

\footnotetext{
${ }^{63}$ Vincent-Antonin Lepinay, "Decoding Finance: Articulation and Liquidity Around a Trading Room," in Do Economists Make Markets? On the Performativity of Economics, ed. Donald MacKenzie, Fabian Muniesa, and Lucia Siu (Princeton: Princeton University Press, 2007), 114.

${ }^{64}$ Jakob De Haan et al, "Why the Stability and Growth Pact Failed?" International Finance 7, no. 2 (2004): 243.
} 
a substantial degree of certainty. Given that Ecofin is the ultimate arbitrator of what rules are respected, but that it lacks the collective capacity to commit itself to such an enforcement regime, the uncertainty present subverts IG's static explanations of fiscal conduct. ${ }^{65}$ Incorporating these kinds of contingencies would strip IG of its simple illustrations of the current problematic and make one incredulous of their explanatory value. Its reliance on probabilistic, though not necessarily statistical, knowledge to explain European integration may compel IG to devise a single numerical standard against which normalcy may be judged. But this approach proves inadequate when variegated notions of appropriate behaviour must be simultaneously calculated and accommodated within the parameters of a single, enforceable framework.

Many of these visions purport a convergence around notions of normalcy and stability. IG falls into this camp because it places the nation-state in the normative center, regarding it as the anchor of EMU. In this sense, the SGP problematic is understood not as the contestation between entrepreneurial and accountable forms of power and their respective technologies of government, but as a reinforcement of state-centrism. Nevertheless, IG is incapable of adequately explaining how the parameters of EMU, and thus the definition of normalcy, are constituted outside the auspices of the state. Even if one could discuss a single, coherent EMU normality and its representation in governance, intergovernmentalism's contributions are limited to an arithmetical aggregation, which is a crude oversimplification without a basis in reality. Therefore, their standardisation of the normalcy thesis is not only conceptually erroneous but factually absurd.

\footnotetext{
${ }^{65}$ Willem Hendrik Buiter, "How to Reform the Stability and Growth Pact?" Central Banking 13, no. 3 (2003): 48-58.
} 
Do not misinterpret this as meaning that EMU is a purely ideational construction without an anchor in the material. In fact, I contend that this is a space that is produced - an artefact - by and composing of processes that are both ideal/cognitive and real/material. A preferred approach determines how the materialisation of this fiscal-monetary space reflects its own politics rather than the projections of disparate periods. Plagued by false dichotomies, lacking a genuine theory of interest and agency while wedded to institutions and concepts removed from the empirical reality of EMU, intergovernmentalism provides a poor explanation of the SGP problematic. Granted sovereign states do play a pivotal role in the construction and regulation of this emerging plane. However, the reductionism privileging the lowest common denominator inherent in this paradigm is overly simplistic and highly questionable. What results is a depoliticised ontology compounded by a malnourished epistemology, which ultimately cannot provide a proper explanation of the trinity of inconsistencies associated with the SGP problematic.

\section{Constructivism: The Normative and Prescriptive}

If intergovernmentalists accounts of risk and the SGP crisis are devoid of any serious contestation over meaning then constructivist preoccupations with perception and ideological factors are a stark contrast. ${ }^{66}$ Identity is neither fixed nor assigned an ontological priority for these theorists. There is no exogenous reality outside of the ideational constitution of EMU to be measured and quantified. According to Luhmann, "the world is constituted by the differentiation of meaning systems, by the difference

\footnotetext{
${ }^{66}$ Jeffrey Checkel, "The Constructivist Turn in International Relations Theory," World Politics 50, no. 2 (1998): 324-48; Thomas Risse, "Social Constructivism and European Integration," in European Integration Theory, ed. Antje Wiener and Thomas Diez (New York: Oxford University Press, 2004), 159-75.
} 
between system and environment." ${ }^{, 67}$ Interests and identities are endogenous as they are constructed through social practice. Hence, the instrumental rationality and atomistic conceptions of social phenomena, informing state-centric understandings of risk and uncertainty, are visibly absent. EMU governance is understood in terms of the metaprocesses of knowledge production. Money creates new geographies of power and generates commentary relating to both its ideational and material properties. Whereas intergovernmentalists prioritise the latter in their assessments of the SGP crisis, and IR more broadly, constructivists emphasise the former as they challenge instrumental rationality and atomistic conceptions of social phenomena. ${ }^{68}$

Rejecting rigid forms of structuralism in addition to positivistic epistemology, constructivism resembles more of an epistemological doctrine grounded in a social ontology rather than a substantive theory. According to Bastiaan van Apeldoorn, it lacks the methodological element which prevents it from "telling us how to go about explaining social change. ${ }^{, 69}$ But constructivists subscribe to a different meaning of structure than neoGramscians or intergovernmentalists. Theirs is a particular hermeneutical version connoting "the configuration of the perceptual field, those wholes articulated by certain lines of force and giving every phenomenon its local value." At its core is the understanding that reality is socially constructed and mediated through intersubjective processes.

\footnotetext{
${ }^{67}$ Niklas Luhmann, Social Systems (Palo Alto: Stanford University Press, 1995), 208.

${ }^{68}$ Thomas Christiansen, Knud Erik Jorgensen, and Antje Wiener, ed. The Social Construction of Europe (Thousand Oaks, CA: Sage Publications, 2001); Uwe Puetter, The Eurogroup (New York: Manchester University Press, 2006); Kathleen McNamara, The Currency of Ideas: Monetary Politics in the European Union (Ithaca, N.Y.: Cornell University Press, 1998).

${ }^{69}$ Bastiaan van Apeldoorn, Transnational Capitalism and the Struggle over European Integration, 16.
} 
Emphasising an ideational and norms-based approach to EMU, constructivists believe that "the consequence of making the individual ontologically primitive... is that the social relations in virtue of which that individual is a particular kind of agent with particular causal properties must remain forever opaque and untheorised." ${ }^{, 70}$ Thinkers, such as Risse, reject the conceptualisation of an a priori and egotistical nation-state with exogenous interests, contending that IG neglects the socialisation and preference formation that results from "collectively shared systems of meaning." ${ }^{, 71}$ Socialisation reinforces the institutions of EMU while simultaneously shaping identities, which are not fixed by constantly produced and renegotiated. In effect, what is witnessed is essentially a dialectic between the ideational and material or experts and politicians. Experts brainstorm the ideas that politicians eventually enact into practice. The Governing Council of the ECB or the Economic and Financial Committee (experts for Ecofin) subscribe to particular paradigms about how to perform their respective duties. Each of these "brain trusts" exemplifies a shared identity that binds their respective members into a consensual style of economic governance. $^{72}$

Stressing intersubjectivity, these are discursively constructed models of reality that contrast with individualist and rationalist assumptions about causality and the main object of analysis. ${ }^{73}$ Constructivists, such as Dyson, emphasise:

'thick' constitutive effects on the properties of states which are discernable in the cognitive dimension of policy and politics, in a policy paradigm that privileges some strategies (e.g. market liberalization and fiscal discipline)

\footnotetext{
${ }^{70}$ Alexander Wendt, "The Agent-Structure Problem in International Relations," International Organization 41 , no. 3 (1987): 343.

${ }^{71}$ Thomas Risse, "Social Constructivism and European Integration," in European Integration Theory, ed. Antje Wiener and Thomas Diez (New York: Oxford University Press, 2004), 160.

${ }^{72}$ Kenneth Dyson, "The Evolving Timescapes of European Economic Governance: Contesting and Using Time," Journal of European Public Policy 16, no. 2 (2009): 290.

${ }^{73}$ Markus Jachtenfuchs et al., "Which Europe? Conflicting Models of the Legitimate European Political Order," European Journal of International Relations 4 (1999): 409-45.
} 
over others (e.g. active demand management), and in selective framing of discourse to convince publics. ${ }^{74}$

As already mentioned, the SGP is itself characterised by a monetarist language espousing "price stability" and "sustainability" in the hope of constituting a "stability culture" within EMU ${ }^{75}$ At least that was the intended purpose. The internalisation of values associated with the paradigm of "sound money" was to have this "discernable" effect alluded to above by Dyson. Member States are supposedly conditioned to adhere to the SGP as the institutionalisation of fiscal discipline is legitimated in the definition of conduct. This approach adds an often lacking and underdeveloped ideational dimension to EMU debates while in the process unsettling a static conception of "EMU." In contrast to IG, neither structure not agency is assigned ontological priority. Rather they are given equal weight in the attempt to "transcend the dichotomy of voluntaristic individualism... and deterministic structuralism."

A cultural economy is constructed along the lines of what McNamara describes in The Currency of Ideas. ${ }^{77}$ As a macrocultural formation, EMU influences how agents define their interests and come to form their identities through cognitive processes. McNamara may have underestimated the resistance elites and publics demonstrated towards the call for increased tax rates in the vein of curtailing deficits but she did stress the role of ideas in the contestation surrounding the SGP. ${ }^{78}$ Depending on whether identity or economic ideas are

\footnotetext{
${ }^{74}$ Kenneth Dyson, "EMU as Europeanisation: Convergence, Diversity and Contingency" in The Euro: European Integration Theory and Economic and Monetary Union, ed. Amy Verdun (Lanham, Md.: Rowman \& Littlefield Publishers, 2002), 92.

${ }^{75}$ Michael Artis and Bernhard Winkler, "The Stability Pact: Safeguarding the Credibility of the European Central Bank," CEPR Discussion Paper 1688 (1997); Martin Marcussen, Ideas and Elites: The Social Construction of Economic and Monetary Union (Aalborg: Aalborg University Press, 2000).

${ }^{76}$ Bastiaan van Apeldoorn, Transnational Capitalism and the Struggle over European Integration, 15.

${ }^{77}$ Kathleen McNamara, The Currency of Ideas: Monetary Politics in the European Union.

${ }^{78}$ Kathleen McNamara, "Economic Governance, Ideas and EMU: What Currency Does Policy Consensus Have Today?" Journal of Common Market Studies 44, no.4 (2006): 803-821.
} 
stressed in explaining monetary integration, it is possible to demarcate constructivism into two, but potentially more, strands. ${ }^{79}$ Underscoring identity politics, the first camp submits that EMU is primarily a political phenomenon based on the symbolic nature of the "euro" rather than any economic criteria. ${ }^{80}$ Juxtaposed against national visions of Europe, a new framework of identity politics is established that fosters monetary integration. Since money is perceived as a symbol of national identity - the US greenback being the most popular example - identity-orientated constructivists discuss the constitution of a European sense of self developing in conjunction with national versions.

Given that money is the ultimate manifestation of power, a constructive-functional relationship between identity and power is then posited. Symbols, such as the euro, are imbued with the authority to define tangible existence. In this regard, "social constructivism occupies a - sometimes uneasy - ontological middle ground between individualism and structuralism." 81 Testing and proving this relationship empirically is a formidable task. But even Risse himself admits that the intent is not to devise a substantive theory of European integration set to compete against IG or neofunctionalism, as much as "an ontological perspective or meta-theory." 82

The second camp focuses on the constitutive role of economic ideas in their explanations of EMU. True to the constructivist approach, scholars like McNamara attribute the success of monetary integration to an economic, ideational consensus rather than economic interests alone. Elites mobilise support for EMU by projecting specific

\footnotetext{
${ }^{79}$ For example, Bastian van Apeldoorn discusses a "critical" constructivism rooted in historical materialism, 16-21.

${ }^{80}$ Thomas Risse et al., "To Euro or Not to Euro? The EMU and Identity Politics in the European Union," European Journal of International Relations 5, no. 2 (1999): 147-87.

${ }^{81}$ Thomas Risse, "Social Constructivism and European Integration," 161.

82 Thomas Risse, "Social Constructivism and European Integration," 174.
} 
macroeconomic beliefs onto society. Quite often these are neoliberal ideas that privilege fiscal austerity, low inflation and a strong and stable exchange rate. Together they comprise a monetarist policy consensus that seeks to address the uncertainty inherent in collectively managing heterogeneous economies. McNamara recognises that:

ideas are critical in the monetary realm because of continuing uncertainty over the basic workings of the macro economy, the difficulty of collecting and interpreting signals from macroeconomic data about the effects of policy, and the lack of agreement over what constitutes 'correct' macroeconomic policy. $^{83}$

Diverging views over proper budgetary conduct lie at the heart of the SGP crisis.

The legitimisation of a particular policy direction depends on the degree to which the sound money paradigm is internalised. It must capture the imagination of leaders and officials who are embedded within their respective domestic contexts. These actors in turn constitute their identities in relation to EMU as a "macrocultural formation." Embodied in this cultural terrain are shared ideas about the composition of the eurozone and its operations. Ideas do not simply reflect material conditions, they:

structure debate, give direction to policy development, and provide legitimating formulae in terms of which action is made defensible. Their long-term effects are produced through their institutional embodiment which gives them a certain 'stickiness.' 84

Policy convergence around the SGP is discursively and culturally contingent. In this manner, an analysis of ideologies does merit consideration as values and norms inform the policy learning process and its outputs.

Championing an anti-individualist ontology, constructivists approach the SGP problematic primarily from an ideational perspective. Whereas prior to EMU the exchange rate cooperation regime was perceived as having relatively benign political effects, the

\footnotetext{
${ }^{83}$ Kathleen McNamara, The Currency of Ideas: Monetary Politics in the European Union, 64.

${ }^{84}$ Kenneth Dyson, "EMU as Europeanisation: Convergence, Diversity and Contingency," 94.
} 
introduction of the Pact's disciplinary measures began to exert serious political pressures on national governments. ${ }^{85}$ Demonised for its arbitrary reference values that constrain national governments, the SGP has received condemnation from experts and politicians alike. At loggerheads are two competing discourses. One advances the vision of the EU as a "stabilisation state," which privileges the "sound money" paradigm championed by the European Central Bank. ${ }^{86}$ Perceived in technocratic terms, stabilisation is now within the competence and jurisdiction of the EU. Hence, "the EU is no longer a regulatory state" but "an emergent stabilisation state, dedicated to improving the economic efficiency of Europe by establishing and safeguarding economic stability." ${ }^{87}$ Heipertz and Verdun identify a set of core tenets characteristic of this stability paradigm. They include:

1) the overarching economic parameter to be attained is 'price stability' (low inflation);

2) price stability is a precondition for growth, not its trade-off, and growth and the expense of price stability only translates into inflation;

3) price stability is ensured by a central bank that sets interest rates independently of the (opportunistic, time-inconsistent) political process;

4) the central bank can fulfill its mandate only if other fields of economic policy do not run counter (e.g. high levels of public debt). ${ }^{88}$

Its influence is visible as the monetarist language pervades EMU and legitimates its fiscal discourse and cognitive frames. These principles are also reflective of the Bundesbank model, which, as the precursor to the ECB, was transposed onto the European level. ${ }^{89}$

\footnotetext{
${ }^{85}$ Kathleen McNamara, "Economic Governance, Ideas and EMU: What Currency Does Policy Consensus Have Today?" 803-21.

${ }^{86}$ Kenneth Dyson, The Politics of the Euro-Zone (New York: Oxford University Press, 2000); Kenneth Dyson and Kevin Featherstone, The Road to Maastricht (Oxford: Oxford University Press, 1999); Martin Marcussen, Ideas and Elites: The Social Construction of Economic and Monetary Union (Aalborg: Aalborg University Press, 2000).

${ }^{87}$ Kenneth Dyson, "EMU as Europeanisation: Convergence, Diversity and Contingency," 101.

${ }^{88}$ Martin Heipertz and Amy Verdun, "'The Stability and Growth Pact Theorizing a Case in European Integration," Journal of Common Market Studies 43 (2005): 1001.

${ }^{89}$ Kenneth Dyson, "The Euro-Zone in a Political and Historical Perspective," in Political Aspects of the Economic and Monetary Union, ed. Soren Dosenrode (Aldershot: Ashgate, 2002), 17-40.
} 
According to Hodson, macroeconomic coordination is infused with "prescriptive uncertainty" regarding the appropriate solution to the problem of fiscal spillover, which when coupled with "substantive uncertainty over the definitions of the medium-term target" undermines efforts at effective coordination. ${ }^{90}$ Therefore, the architects of EMU intended to minimise the associated costs by instituting an $\mathrm{OMC}$ based on a consensus that fiscal profligacy is to be avoided. Constructivists contend that this project of "translating the paradigm into practice" was jeopardised because of a new ideational compromise, which saw the significance of fiscal discipline deteriorate. ${ }^{91}$ In their view, the current SGP crisis reflects the conflict between two competing discourses. One discourse continues to privilege price stability as is articulated by the ECB. The other has its anchor in domestic politics and expresses the opinion that governments must first be accountable to their domestic constituents and their welfare. Pitted against each other are the experts/ technocrats versus the politicians/national representatives with each camp prioritising different aspects of monetary and fiscal management. National elites and politicians, especially in France, advocate an opposing position whose budgetary laxity is buttressed by their vocal spite for the much unloved SGP. Such hostility against the Pact continues to this day. Convergence around these differing beliefs has produced an asymmetry in policy compelling some to favour "loose money rather than sound money.",92

Together these frames constitute a threat to a "stability culture" where EMU identities and interests are defined in relation to domestic contexts. National variations

\footnotetext{
${ }^{90}$ Dermot Hodson, "Macroeconomic Co-ordination in the Euro Area: The Scope and Limits of the Open Method," Journal of European Public Policy 11, no. 2 (2004): 235.

${ }^{91}$ Martin Heipertz and Amy Verdun, "The Stability and Growth Pact Theorizing a Case in European Integration," 1002.

${ }^{92}$ Lee Miles, "Euro-Outsiders and the Politics of Asymmetry," European Integration 27, no. 1 (2005): 12.
} 
persist in the expression of capitalism according to Dyson. ${ }^{93}$ His analysis leads him to conclude that this intersubjective understanding amongst elites, which purports neoliberal ideals, is not homogeneous across Europe. Differential processes exist for adopting the mantra of price stability and translating it into institutional practice. However, Dyson's rationalistic approach is decidedly muted on the topic of how this macrocultural manifestation is actually produced. That task is more central to the scholarship of Risse who espouses the "social psychological notion of entitativity." For him "the euro makes Europe real and reifies it as a political order, since it provides a visible link from Brussels to the daily lives of the citizens." ${ }^{94}$ Here the "thick" constitutive effects associated with monetary integration are thought to precipitate the construction of a European polity and identity. The integrity of such a claim is outside the scope of this dissertation. Yet, the strategic selection and internalisation of first monetarist values and then their rejection is paramount to grasping the ideological inconsistency at the heart of the SGP crisis. Europe as a "stabilisation state" was undermined, although not completely displaced, by an alternative mode of representation.

Opposite is the conception of the EU as a "regulatory state," which is touted by thinkers, such as Majone, as the successor to the Keynesian welfare state. ${ }^{95}$ Arguably antithetical to many, if not all, of the monetarist criteria listed above, governance for the public interest is:

defined as market control, market enhancement and social protection... through the delegation of these functions by the state to a growing army of relatively autonomous regulatory and similar executive agencies. ${ }^{96}$

\footnotetext{
${ }^{93}$ Kenneth Dyson, "EMU as Europeanisation: Convergence, Diversity and Contingency," 93.

${ }^{94}$ Thomas Risse, "The Euro between National and European Identity," in The Year of the Euro, ed. Robert M. Fishman and Anthony M. Messina (Notre Dame, ID: Notre Dame University Press, 2006), 79.

${ }_{95}^{95}$ Giandomenico Majone, Regulating Europe (London: Routledge, 1996).

${ }^{96}$ Roger King, The Regulatory State in an Age of Governance (New York: Palgrave Macmillan, 2007), 4.
} 
Here the main protagonists are politicians (as opposed to experts) who subscribe to the notion that the welfare and "real" needs of their national electorates supersede the abstract conditions modelled by the ECB. Eventually, it was the former that prevailed in 2003 as national interests were seen to trump monetarist dictates. A new broader ideational compromise was reached. ${ }^{97}$ Nonetheless, I would caution about observing this normative consensus in absolute terms. It is not a "black or white" situation where one discourse dominates to the complete exclusion of the other. More accurately, the convergence of views necessary for any European macroeconomic synchronisation depends on striking a balance between new monetarism and neo-Keynesian demand management. Balance, however, does not imply parity. This is most notable when explaining the lack of fiscal compliance in reference to the "epistemic communities" which inform governmental decisions.

How institutional socialisation and shared beliefs shape the conceptualisation of interests occupies the research agenda of those constructivists attempting to explain the SGP crisis. ${ }^{98}$ Reluctance on part of the Ecofin Council to sanction Germany and France for their excessive deficits stems from a new consensus adopted by its constituent members (i.e. national finance ministers), coupled with effective peer pressure in an environment where qualified majority voting dictates the outcome. EU economic convergence relies on soft law as a mode of regulation. ${ }^{99}$ Juxtaposed against the legally binding obligations of hard law, Amtenbrink and de Haan submit that "the realm of soft law begins once legal

\footnotetext{
${ }^{97}$ Dermot Hodson, "Macroeconomic Co-ordination in the Euro Area: The Scope and Limits of the Open Method," 231-48.

${ }^{98}$ Uwe Puetter, The Eurogroup (New York: Manchester University Press, 2006); Dermot Hodson and Imelda Maher, "Soft Law and Sanctions: Economic Policy Co-ordination and Reform of the Stability and Growth Pact," Journal of European Public Policy 11, no. 5 (2004): 798-813.

${ }^{99}$ Dermot Hodson and Imelda Maher, "Soft Law and Sanctions: Economic Policy Co-ordination and Reform of the Stability and Growth Pact," 798-813.
} 
arrangements are weakened along one or more of the dimensions of obligation, precision, and delegation., 100

A flexible interpretation of the fiscal framework permits Member States to individually tailor budgetary policies that reflect their heterogeneous economic positions. Each cyclical swing does not have identical effects for each national economy. That is why the "one-size-fits-all" monetary policy of the ECB is critiqued as destabilising for countries remote from the eurozone average. ${ }^{101}$ Subscription to the monetarist discourse, however, provides the necessary cohesive ingredient for collaboration amongst EMU members to occur. That is until a dominant segment of Ecofin altered its orientation and jeopardised this working consensus. Policy and politics now seemed to converge around a neoKeynesian approach to budgetary conduct, or Lisbonisation. Germinating from within the informal "Eurogroup," a new ideational compromise developed.

Attention is often donated to the secretive dialogues of the Eurogroup in order to explain the renegotiated consensus behind the SGP crisis. ${ }^{102}$ At present this informal body is composed of sixteen eurozone finance ministers but in 2003 that number was only twelve. Initiated by the newly elected Socialist government of France in 1997, the Eurogroup was assembled as a vehicle for the politicisation of monetary policy and the protection of national employment strategies. ${ }^{103}$ Fearful that an unaccountable ECB would privilege the objective of price stability above societal welfare and the national industrial

\footnotetext{
${ }^{100}$ Fabian Amtenbrink and Jakob de Haan, "Economic Governance in the European Union: Fiscal Policy Discipline Versus Flexibility," Common Market Law Review 40 (2003): 1076.

${ }_{101}$ Barry Eichengreen and Charles Wyplosz, "The Stability Pact: More Than a Minor Nuisance?" Economic Policy 26 (1998): 65-114.

${ }^{102}$ Uwe Puetter, "Governing Informally: The Role of the Eurogroup in EMU and the Stability and Growth Pact," Journal of European Public Policy 11, no. 5 (2004): 854-70.

${ }^{103}$ Peter H. Loedel, "Multilevel Governance and the Independence of the ECB," in The Euro: European Integration Theory and Economic and Monetary Union, ed. Amy Verdun (Lanham, Md.: Rowman \& Littlefield Publishers, 2002), 131.
} 
and labour market policies necessary to delivery it, the Eurogroup developed as a form of "soft coordination" to encourage insiders to adopt a unified stance against severe austerity measures. According to Feldmann, it was a shift in the mentality of this collective away from the "sound money" paradigm and towards a "loose money" version that explains the SGP crisis. ${ }^{104}$ Ecofin's verdict to suspend the EDP is perceived as an official expression of an informal consensus arrived at in the Eurogroup.

As an "epistemic community," the Eurogroup exemplifies Haas' four principles:

1) a shared set of normative and principles beliefs, which provide a value-based rationale for the social action of community members;

2) a shared causal beliefs, which are derived from their analysis of practices leading or contributing to a central set of problems in their domain and which then serve as the basis for elucidating the multiple linkages between possible policy actions and desired outcomes;

3) shared notions of validity - that is, intersubjective, internally defined criteria for weighing and validating knowledge in the domain of their expertise;

4) a common policy enterprise - that is, a set of common practices associated with a set of problems to which their professional competence is directed. ${ }^{105}$

It supplements the Ecofin Council but lacks the means to enforce policies apart from generating a dialogue where the members can learn to promote a particular economic orientation that is later adopted in a formal setting; namely Ecofin. Coordination and the subsequent articulation of Eurogroup decisions are strictly voluntary as it is not an officially recognised Community institution. Thus, its influence over economic governance is successful only if its members identify themselves with the Eurogroup's position. This requires a deep conviction in the validity of their underlying belief that broader, national stakeholders were best served by protecting German and French, not to mention

\footnotetext{
${ }^{104}$ Horst Feldmann, "The Implementation of the Stability and Growth Pact: Taking Stock of the First Four Years," Journal of European Integration 25, no. 4 (2003): 287-309.

${ }^{105}$ Peter Haas, "Introduction: Epistemic Communities and International Policy Coordination," International Organization 46, no. 1 (1992): 3.
} 
Portuguese, interests. Although this was by no means a homogenous position. ${ }^{106}$ Nor was it one that the majority supported, if one can extrapolate by the Ecofin vote since these are secretive meetings. ${ }^{107}$ Nevertheless, since preferences and identities are constituted at all point of socialisation, both formal and otherwise, such consultations were sufficiently transposed into an arena were qualified majority voting provided the blocking coalition of Germany, France, Italy and Portugal the ultimate victory in the matter.

Puetter notes that "the intensive debates of euro area ministers within the Eurogroup emptied out the agenda of ECOFIN" as it "de facto intervenes at all stages of the decision-making process and has developed into the virtual political centre of the operation of the SGP." "108 Being inherently political there is substantial contestation surrounding what values and prescriptions form the consensus as well as the mechanics for executing the agreed upon agenda. I have already mentioned that these sanctioned appeasements in November 2003 divided Member States. However, constructivists also add their voice to a chorus which contends that these frictions, and the subsequent 2005 reforms that followed, did not fundamentally alter the underlying rationale of the Pact. ${ }^{109}$ Some sort of political protocol, which recognises the significance of curbing fiscal profligacy, is vital for the successful operation of EMU. Of course, any dilution of the Pact that increases the scope for interpretation and leniency is perceived by some as weakening

\footnotetext{
${ }^{106}$ Finland, the Netherlands, Belgium, Austria, and Ireland were opposed to such an appeasement.

${ }^{107}$ Dermot Hodson and Imelda Maher, "Soft Law and Sanctions: Economic Policy Co-ordination and Reform of the Stability and Growth Pact," 808.

${ }^{108}$ Uwe Puetter, The Eurogroup, 3 \& 112.

${ }^{109}$ Martin Heipertz and Amy Verdun, "The Dog that Would Never Bite? What We Can Learn from the Origins of the Stability and Growth Pact;" Uwe Puetter, "Providing Venues for Contestation: The Role of Expert Committees and Informal Dialogue Among Ministers in European Economic Policy Coordination," Comparative European Politics 5, no. 1 (2007): 18-35.
} 
the SGP's already enfeebled enforcement capacity. ${ }^{110}$

Conversely, enhanced manoeuvrability, especially for fiscally responsible states, addresses the charge that the SGP is merely "all 'stick' and no 'carrot' - there are no incentives to encourage good behaviour during periods of economic growth." ${ }^{111}$ That being said, for constructivists, EMU is about striking an accord between new monetarist and neoKeynesian ideas regarding what constitutes as "normal" economic governance; where normal is equated with being ethically "good." More specifically, it is an "expression of a long and informal consensus-building process on the nature and appropriate use of the SGP as a key policy instrument in Stage 3." ${ }^{\prime 12}$ Being more considerate of ideational factors, however, does not preclude constructivism from criticism directed at its analytical postulates. As we shall see in the forthcoming critique, much of this is grounded on false dichotomies and social ontologies where structuralism creeps in to prove increasingly problematic.

\section{Constructivism: The Critique}

On February 8, 2000, the Financial Times published a rare piece on the secrecy and influence of the Eurogroup entitled "Quiet Men Taking Charge." ${ }^{113}$ In hindsight the article should have been called "Loud Few Dictating What to Do" as the quiet majority ultimately failed to carry the day on November 25,2003 . Yes, the paper was referring to the confidential collusions of the Eurogroup and not the Ecofin Council per se. But, as constructivists would hold, the only official authority the former exercises arises through

\footnotetext{
${ }^{110}$ Michele Chang, "Reforming the Stability and Growth Pact: Size and Influence in EMU Policymaking," Journal of European Integration 28, no. 1 (2006): 107-20.

111 Dermot Hodson and Imelda Maher, "Soft Law and Sanctions: Economic Policy Co-ordination and Reform of the Stability and Growth Pact," 810.

112 Uwe Puetter, The Eurogroup, 44.

113 “Quiet Men Taking Charge," Financial Times, 8 February 2000.
} 
the materialisation of its collective voice in an institutionalised Community forum; namely Ecofin. For that matter, the Financial Times could have probed the affairs of countless other informal groups (i.e. Free Masons, Skulls and Bones, etc...) where consensus is vital for organisational integrity. However, without explaining how the ideational conditions the "multiplicity and variability of modes of subject formation, and the relations to the self engendered and enjoined in specific practices," such arguments, as proposed by social constructivists, fail to elucidate a proper understanding of the SGP problematic. ${ }^{114}$ This line of reasoning is developed in this critique of constructivist contributions to the SGP crisis debate.

Following a path similar to my rebuttal of IG, I begin with questioning their theoretical coherence and, in particular, as it pertains to agency and interests. Many constructivists are themselves not immune from the criticism that they lack a coherent theory of agency. Ideational affinities and the intersubjective structures that produce them cannot come at the expense of actors and their agendas. These need to be problematised in order to avoid idealism's tautological conundrums. Continuing, I broach the subject of power. Limited to ideas, economic or otherwise, an "extra-discursive" domain is necessary to impose restrictions on the production of meaning. This has grave implications for how we come to understand the SGP problematic as it introduces constraints exogenous to the model. Alternative assessments are also stifled. Lastly, as with IG, constructivism subscribes to certain false dichotomies; private versus public being the principal one. By analysing the explicit inadequacies located within the constructivist approach together with their implicit conclusions, I demonstrate that this metatheoretical position does not provide

\footnotetext{
${ }^{114}$ Nikolas Rose and Peter Miller, Governing the Present: Administrating Economic, Social and Personal Life, 4.
} 
a clear and sufficient understanding of the SGP crisis.

Although constructivist expositions of European integration provide refreshing insights into the intersubjective constitution of social reality, and in particular the transformative effects on identities, they resemble less of a coherent theory of IR and more of a collection of various metatheoretical positions. These tend to embody "normative claims about what 'good' social science should be" but "rule as inadmissible any substantive theory that accords material factors, or objective structures, an independent casual role." 115 Such critiques are even echoed by constructivists themselves who, like Jeffrey Checkel, recognise their deficiencies in "theory development and research design." 116 An overemphasis on the role of social structures and norms often comes at the expense of agents, which simply compounds the problem. Failing to problematise agency, and interests, constructivists tend to insinuate a sense of ownership over the construction of truth as "social discourses are controlled and promoted... by socio-economic classes, gender groups.....and so on."117

Such a reading neglects the performativity of practice in the constitution of EMU and its subjects. But the meaning attached to the SGP as a monetary space symbol arises from the production of knowledge as it "opens up technical and depoliticised economic practice to political scrutiny."118 If elites do construct discourses and identities, why and how are they adopted by common Europeans? What is it that allows individuals to be

\footnotetext{
${ }^{115}$ Colin Wight, Agents, Structures and International Relations, 163.

${ }^{116}$ Jeffrey Checkel, "Social Construction and Integration," ARENA Working Papers 14 (1998b): 10, http://www.arena.uio.no/publications/wp98_14.htm.

117 Angus Cameron and Ronen Palan, The Imagined Economies of Globalization (Thousand Oaks, CA: Sage, 2004), 48.

${ }^{118}$ Marieke de Goede, "Introduction: International Political Economy and the Promises of Poststructuralism," in International Political Economy and Poststructural Politics, ed. Marieke de Goede (New York: Palgrave Macmillan, 2006), 7.
} 
manipulated and induced into certain behaviour? And are all discourses susceptible to calculative exploitation or are there exceptions? Despite:

their ontological commitment to a process-oriented vision of social reality ("mutual constitution"), constructivists have largely ignored and failed to model the specific mechanisms through which social institutions such as norms connect to agents. ${ }^{119}$

Without clarifying what "constitution" actually entails, aside from some underspecified suggestions of social learning, Checkel's point is well taken. Agency and interests must be problematised in order to understand how discursive instantiations and ideational affinities were constituted during the SGP crisis.

Case in point, a recent September 2007 spat between the French President Nicolas Sarkozy and his compatriot, Jean-Claude Trichet, the president of the ECB, encapsulated economic issues that are typically inaccessible to the general public. Yet, it had the effect of reaffirming the "deeply held belief among many French people that their economic problems are created largely by outside forces, such as globalisation, free trade... the European Commission-or the euro and the ECB." ${ }^{120}$ This dispute associated fiscal profligacy with a broader spectrum of grievances, in the process creating a new objectivity. Constructivists, however, neglect to problematise this actualisation of EMU. They fail to adequately explain how new knowledge and interests are produced and legitimated through the politics of uncertainty. Moreover, this needs to be accomplished in a coherent fashion. Doing so permits us to understand the formation of a European economy of power "not as an exploitative system designed by particular interests, but as a performative practice, the reiteration of which in the space of everyday life" grants uncertainty its constitutive

\footnotetext{
119 Jeffrey Checkel, "Social Construction and Integration," 10

120 "Faulty Sarkonomics," The Economist, September 29, 2007, 15.
} 
power. ${ }^{121}$ An analysis of the performative dimension of technologies of power helps render EMU visible and its corresponding challenges manageable.

Dyson attempts to tackle this question of agency by asserting a position complementary to that of Puetter. ${ }^{122}$ It is an exclusive core of executive actors, in the form of the ECB, the EFC, and the Eurogroup, who dictate the direction and pace of integration through their cognitive leadership. Bound by the sound money paradigm, this technocratic community legitimises the institutionalisation of new monetarist policies. Arguably, "EMU has centralised the economic stabilisation function at the EU level." ${ }^{, 123}$ From this line of reasoning, Dyson purports to replace the regulatory state with the stabilisation state as alluded to above. Yet, this elite driven, top-down imposition of a macro-cultural order is antithetical to what actually occurred. The opposition to the SGP originated from Member States. It was the politicians who were hostile to sacrificing control of their national economies at the altar of some arbitrary reference values. Dyson never applied these ideas to the direct analysis of the Ecofin crisis and for good reason. Their fallacious character removes them from reality and is not helpful in explaining the problematic.

Ideas are significant in conditioning EMU. However, constructivists fail to adequately explain how the mutual constitution between the ideational and the material manifests itself. Without problematising agency in order to elucidate the paths through which socialisation occurs, these accounts take ideas as given and are bankrupt when it comes to proposing a reality where material forces may play an independent causal role. This idealism is especially pronounced in the work of Alexander Wendt.

\footnotetext{
${ }^{121}$ Marieke de Goede, "Introduction: International Political Economy and the Promises of Poststructuralism," 9.

122 Kenneth Dyson, The Politics of the Euro-Zone (New York: Oxford University Press, 2000).

${ }^{123}$ Kenneth Dyson, "EMU as Europeanisation: Convergence, Diversity and Contingency," 101.
} 
All too often, Wendt, like the numerous constructivists that his work informs, is indecisive about the relationship between the material and the ideational. There are times when he suggests that social reality may be "ideas all the way down." 124 On other occasions, however, he grants materiality an independent causal effect only to revert back to assigning ideas the principal role. ${ }^{125}$ Such flip-flopping has attracted a deluge of criticism. Campbell attacks Wendt for his "moral commitment to an "epistemic realism"” and rationalist anthropomorphism of the state. ${ }^{126}$ Wight also challenges the integrity of such theoretics. By neglecting materiality and defining social structures in terms of ideas rather than explaining how they are constructed and renegotiated, constructivists are prone to idealistic explanations of EMU. ${ }^{127}$ They seem blind to the reconfiguration of material conditions and interests resulting from the 2001 market correction, which underpinned the backlash against the disciplinary SGP. Even the institutions constructivists profess have sway, such as the Eurogroup, are restricted to secretive deliberations and lack the formal competence to enact fiscal policy. The extent to which their ideas actually translate into governance is quite contentious and rests on anecdotal evidence. Such constructivist limitations severely hinder a proper understanding of the problematic.

This ambiguity is most pronounced with reference to the "extra-discursive" restrictions on the production of meaning. It imposes restrictions of the production of meaning and curtails the politics of representation. In effect, this limits how knowledge is constructed in a predetermined manner. But a (governable) European economy is discursively produced and legitimated. Referring to Rose and Miller, "modes of managing,

\footnotetext{
${ }^{124}$ Alexander Wendt and Daniel Friedheim, "Hierarchy under Anarchy: Informal Empire and the East German State," International Organization 49, no. 4 (1995): 692.

125 Alexander Wendt, Social Theory of International Politics (Cambridge: CUP, 1999), 109-13.

${ }^{126}$ David Campbell, "Political Prosaics, Transversal Politics," 12-13.

${ }^{127}$ Colin Wight, Agents, Structures and International Relations, 158.
} 
intervening and administrating become modes of power to the extent that they are generalised and linked to a centre." ${ }^{128}$ Erecting parameters external to this contingent practice of representation excludes the possibility for differentiated assessments of the SGP and its reforms. Such an underlying reality may discriminate against certain forms of political discourse rather than recognising how these may "open a particular space for theoretical arguments and the truth claims that they entail., ${ }^{, 129}$ How new knowledge is constituted through the politics of uncertainty and its associated technologies of power is often neglected.

This deficiency is most unsettling in relation to the construction of normalcy. No longer is its formation synoptic of contested discourses embedded in technologies of government. An extra-discursive domain now imposes restrictions on the production of meaning of what is considered normal conduct. Intersubjective modes of representation may be at the heart of constructivist doctrine but their constitution is fraught with exogenous conditions that interrupt their actualisation. Uncertainty and risk, as frames for the socialisation process, are therefore susceptible to this extra-discursive logic which is divorced from the site of articulation. Removed from discursive instantiations, this limit on what is permissible hinders social constructivist contributions to EMU since the difference between perception and actualisation is suspended. Subjectivity materialises at these points of social interaction, which are nevertheless subject to some external force.

Similar to the submissions of critical political economy theorists, such as Magnus Ryner or Bob Jessop, which the next section will discuss, an underlying autonomous reality dictates the parameters of how social phenomena can be constituted and operates. Whereas

\footnotetext{
${ }^{128}$ Nikolas Rose and Peter Miller, Governing the Present: Administrating Economic, Social and Personal Life, 21.

${ }^{129}$ Peter Miller and Nikolas Rose, "Governing Economic Life," 6.
} 
historical materialists may welcome such an interpretation as extra-semiotic mechanisms have the potential to dialectically reinforce the materiality of structures, it is damaging for constructivists intent on explaining the SGP crisis as the management of systems of representation. ${ }^{130}$ The regulation of uncertainty is dependent on how it is framed as an object of governance. A clear analytical framework delineating how both risk and uncertainty are transformed into modalities of rule in order to render EMU real is necessary. Lacking one we are left with deciphering not an autonomous fiscal-monetary space with its own set of articulations but one susceptible to an exogenous influence directing its constitution.

Additional artificial distinctions often present themselves in constructivist contributions to the EMU debate. One of the most dubious is a reinforced public versus private dualism. Granted, recent liberal versions of constructivism are beginning to acknowledge that the state and its institutions do not monopolise the entire public sphere. ${ }^{131}$ Many, however, remain quite statist in their focus on the norms and discourses of national elites and institutions. Unfortunately, this approach ignores the private and multilevel dimensions of EMU management bound by heteromorphic relations. But a proper understanding of the SGP problematic demands being more cognisant of multiple discourses, which contribute to the contestation surrounding fiscal discipline. These do not necessarily have to be produced and sanctioned by officials of the state. My analysis acknowledges this potential.

\footnotetext{
${ }^{130}$ Bob Jessop, State Power: A Strategic-Relational Approach (Malden, MA: Polity Press, 2008), 237-40.

${ }^{131}$ Vivien Schmidt, Democracy in Europe: The EU and National Polities (New York: OUP, 2006); Martin Marcussen and Jacob Torfing, ed., Democratic Network Governance in Europe (New York: Palgrave Macmillan, 2007).
} 
While Hodson and Maher are correct to insinuate that the visible drivers behind economic coordination at the EU level are nation-states, they also stress the significance of "soft law" in this process. ${ }^{132}$ In juxtaposition to "hard law," they adopt Synder's definition. He stipulates that "rules of conduct which in principle have no legally binding force, but which nevertheless may have practical effects" are considered within the realm of soft law. ${ }^{133}$ But as mentioned above, the national positions tabled in the Ecofin Council reflect the heterogeneity located across Europe. Irrespective of the margin of discretion available to leaders in this forum, political elites must rely on the tacit approval, if not vocal support, of non-state actors in order to legitimise their policies. By neglecting this growing force comprised of firms and other non-state actors in their analyses of the problematic, constructivists reinforce a false dichotomy. Arguably, this becomes a graver omission in the modern era of globalisation with, what is the supposed acceleration of the "hollowing out of the state."

Better classified as an ontological approach, constructivist accounts of EMU and the SGP crisis are prone to overemphasising "the role of social structures and norms at the expense of the agents who help create and change them in the first place." ${ }^{\prime 134}$ Quite often, we are presented with an embedded institutional context of policy-making, such as Ecofin, without regard for the individual actors who influenced the course of action taken. France's finance minister Francis Mer was persistently vocal about renegotiating the SGP. His hostility was echoed by both Chirac and Schröder. ${ }^{135}$

\footnotetext{
${ }^{132}$ Dermot Hodson and Imelda Maher, "Soft Law and Sanctions: Economic Policy Co-ordination and Reform of the Stability and Growth Pact," 810.

${ }^{133}$ Francis Snyder, "The Effectiveness of European Community Law: Institutions, Processes, Tools and Techniques," in Implementing EC Law in the United Kingdom: Structure s for Indirect Rule, ed. Terence Daintith (Chichester: Wiley, 1995), 64.

${ }^{134}$ Jeffrey Checkel, "The Constructivist Turn in International Relations Theory," 324.

${ }^{135}$ George Parker, "Germany and ECB Argue over Pact's Collapse," Financial Times, December 1, 2003.
} 
Even when actors are recognised, they tend to be public figures thereby reinforcing a public versus private dichotomy found in constructivism. Power and authority, however, do not rest solely with state officials but also with firms, citizens and other non-state actors. ${ }^{136}$ The SGP crisis is illustrative of how quickly governments rejected the monetarist orthodoxy in favour of neo-Keynesian demand-management because of a shift in individual public opinion. ${ }^{137}$ Without understanding this dynamic, constructivists ignore the changing configuration of EMU management; one that operates at multiple sites and "as complex ensembles of discontinuous elements and forces bound by heteromorphic relations. ${ }^{138}$ Instead of attempting to determine the essence of this spatial-temporal order, it is more useful to map the historically continent social and institutional processes, experts, agencies and interests connected with regulating EMU.

\section{Critical Political Economy: The Normative and Prescriptive}

Troubled by the failure of conventional IR theories to adequately conceptualise the constitutive power of transnational structures and the hegemony of capital's discourse production, historical materialists wish to remind us that capitalist market structures are the "terrain" where all social struggles are waged. ${ }^{139}$ Indeed, they consider this a grave omission as "market forces have come to constitute the dominant principle of social organisation to which all other principles and media of social organisation have become

\footnotetext{
${ }^{136}$ Maria Green Cowles, "Non-state Actors and False Dichotomies: Reviewing IR/IPE Approaches to European Integration," 30.

${ }^{137}$ Shawn Donnelly, "Explaining EMU Reform," Journal of Common Market Studies 43, no. 5 (2005): 962.

${ }^{138}$ Mitchell Dean, "Putting the Technological Into Government," History of the Human Science 9 (1996): 55.

${ }^{139}$ Louis Althusser, Politics and History (London: New Left, 1972); Robert W. Cox, Production, Power, and World Order: Social Forces in the Making of History (New York: Columbia University Press, 1987);

Bastiaan van Apeldoorn, Transnational Capitalism and the Struggle over European Integration.
} 
subordinate." ${ }^{140}$ With this in mind, the European political economy is often presented as a system developing in accordance with the logic of capital which is transnationally embedded in a finance-led regime of accumulation. ${ }^{141}$

Although traditional, "vulgar" Marxists have failed to make any substantial contribution to the SGP debate, new ideas are being posited by the neo-Gramscian critical theoretical approach to IPE. In reference to the SGP debacle, this literature borrows extensively from Giandomenico Majone and its regulation school cousin. The SGP represents a mode of regulation within this "capitalocentric" configuration. It is an AngloAmerican dominated form of global finance that exerts a hegemonic force over the European economy. Indicative of Gill's "disciplinary neo-liberalism," this European socio-economic order exhibits the hegemony of capital's discursive production. ${ }^{142}$

The original SGP was the consolidation of a particular capitalist regulatory framework. It reflected the tension between the German model, rooted in an ordoliberal tradition, and the Anglo-American neoliberal paradigm. ${ }^{143}$ Building on this class struggle for power to explain the disruption of the SGP regime, Cafruny and Ryner posit that: the aspiration of the European 'power bloc' of dominant socio-economic interests and political elites to build a monetary union designed to promote competitiveness, regional autonomy and sustained growth is inconsistent with the neo-liberal underpinnings of the system as it has developed since the Maastricht Treaty. This is because this neo-liberalism is inherently connected to a transnational financial and monetary order, which is configured to displace economic and social contradictions from the United States to

\footnotetext{
${ }^{140}$ Bastiaan van Apeldoorn, Henk Overbeek and Magnus Ryner, "Theories of European Integration: A Critique," in A Ruined Fortress? Neoliberal Hegemony and Transformation in Europe, ed. Alan W. Cafruny and Magnus Ryner (Lanham, Md.: Rowan \& Littlefield, 2003), 18.

${ }^{141}$ Hans-Jurgen Bieling, "EMU, Financial Integration and Global Economic Governance," Review of International Political Economy 1, no. 3 (2006): 421.

142 Stephen Gill, "European Governance and New Constitutionalism: Economic and Monetary Union and Alternatives to Disciplinary Neo-liberalism in Europe," New Political Economy 3, no. 1 (1998): 5-26.

${ }^{143}$ Bastiaan van Apeldoorn, Transnational Capitalism and the Struggle over European Integration, 71-82.
} 
other parts of the world, including Europe. ${ }^{144}$

Furthermore, Cafruny also points to the contradictory nature of EMU by highlighting how the prospects for the "strategic orientation of an embryonic transnational class" were undermined by national class calculations. ${ }^{145}$ Elites and publics alike were not prepared to pay the costs of meeting the budgetary criteria in countries such as France, Germany or Italy. Guaranteeing the ECB's objective of price stability at a time when national economic performance was poor proved untenable. In order to "embrace the regulatory changes required to stimulate post-industrial employment... extensive adjustment of tightlycoupled social and production systems" was necessary, which "may in turn provoke an increasingly volatile politics of reform." ${ }^{146}$ Such a politics of reform culminated in the suspension of the EDP on November 25, 2003.

Consequently, "EMU firmly subordinates macroeconomic policy to short-term global financial markets in such a way that the expansion of liquidity becomes conditioned on the disciplinary judgements those markets make." ${ }^{147}$ Mediated by this disciplinary power of capital, or what Stephen Gill labels as "new constitutionalism," EMU governance reinforces the very structural relations that subject Europe to a foreign agenda with what are often competing interests. What is witnessed is the "separation of economic policies from broad political accountability in order to make governments more responsive to

\footnotetext{
${ }^{144}$ Alan Cafruny and Magnus Ryner, "A Coming Crisis of the Euro? The Transatlantic Subordination and Social Contradictions of the EMU" (Paper Presented at the Annual Meeting of the International Studies Association, Montreal, Quebec, Canada, March 17-20, 2004), 1.

${ }_{145}$ Alan Cafruny, "Europe, the United States, and Neoliberal (Dis)Order," in A Ruined Fortress? Neoliberal Hegemony and Transformation in Europe, ed. Alan Cafruny and Magnus Ryner (Lanham, Md.: Rowan \& Littlefield, 2003), 287.

${ }^{146}$ Martin Rhodes, "Varieties of Capitalism' and the Political Economy of European Welfare States," New Political Economy, 10, no. 3 (2005): 368.

${ }^{147}$ Alan W. Cafruny and J. Magnus Ryner, Europe at Bay: In the Shadow of US Hegemony (Boulder: Lynne Rienner, 2007), 9.
} 
market forces" and less "to popular-democratic forces and processes." ${ }^{\text {148 }}$ Risk management is a central apparatus of new constitutionalism as it depoliticises governance by displacing responsibility away from officials and elected decision-makers. However, this neo-liberal regulatory framework is proving unsustainable in Europe as it lacks the necessary cultural and political foundations for stability. Without these institutionalised social norms and rules, neoliberal market adherence generates games of "competitive austerity," pitting Member States against each other in fiscal contests that strain relations rather than foster cooperation. ${ }^{149}$

Although this tendency to treat capitalism as a transcendental "totality" driving historical and societal change is visible throughout the historical materialist literature, certain thinkers, such as Ryner or Jessop, are cautious about the complications such orthodoxy entails. In a similar fashion, one has to question the grounds for assigning an excessive amount of explanatory weight to the structural power of any phase of capitalism. I revisit these inadequacies in the critical segment of this section. For the moment it is fitting to introduce additional core tenets associated with this school of thought used to explain the SGP. Such a review identifies commonalities located in the various branches of Marxist thought.

As a structural perspective, critical political economy attempts to explain EMU integration as the reconfiguration of patterns of accumulation and regulation, which consolidate power in a singular class structure. Any serious conceptualisation of agency and strategy is severely limited as these are reduced to the commodification and the

\footnotetext{
${ }^{148}$ Stephen Gill, "European Governance and New Constitutionalism: Economic and Monetary Union and Alternatives to Disciplinary Neo-liberalism in Europe," 5.

${ }^{149}$ Alan Cafruny and Magnus Ryner, "A Coming Crisis of the Euro? The Transatlantic Subordination and Social Contradictions of the EMU."
} 
exploitation of labour situated in capitalist modes of production, reproduction and distribution of wealth. ${ }^{150}$ Antagonisms are a corollary of the social relations of production within this class divided space. These attempts to incorporate relational dynamics in the effort to refine vulgar Marxism intrigued the likes of Poulantzas, who proposed an early "strategic-relational" approach in his endeavour to explain the codification of the power of capital in a centralised state. ${ }^{151}$

Granted, recent CPE may be less captivated than orthodox Marxism by the significance of the structure-agency problematic in a one-dimensional social reality. Class is increasingly being defined in relational terms rather than a subject or group. GibsonGraham posits class to be "the social process of producing and appropriating surplus labour (more commonly known as exploitation) and the associated processes of surplus labour distribution." 152 Though such conceptualisations attempt to address the notion of an $a$ priori identity whose political orientation may be predicated in advance, devoid of a historical context, class interests are still premised primarily on structural relationships. Quoting Jessop:

Since the structure of the social world is always more complex than any social force can conceive and its overall evolution lies beyond the control of any social force, strategic coordination can only occur in the context of uncontrolled and anarchic structural coupling of coevolving structures. ${ }^{153}$

Quite frequently, this implies that Europe is embedded in an underlying "economy" which conditions class "consciousness" and its "formation.",154

\footnotetext{
${ }^{150}$ Bastiaan van Apeldoorn, Transnational Capitalism and the Struggle over European Integration, 3.

${ }^{151}$ Nicos Poulantzas, State, Power, Socialism (London: Verso, 1978).

${ }^{152}$ J.K. Gibson-Graham, The End of Capitalism (As We Knew It): A Feminist Critique of Political Economy (Oxford: Blackwell, 1996), 52.

${ }^{153}$ Bob Jessop, State Theory: Putting Capitalist States in Their Place, 359.

${ }^{154}$ Kees van der Pijl, Transnational Relations and International Relations (New York: Routledge, 1998).
} 
Gramsci opposed this economic determinism as the basis for societal antagonisms. Instead, he sought to reintroduce the political as a constitutive force of society. For neoGramscians, "hegemony" is the product of the struggle between competing collective wills which is institutionalised in the form of the state. Accordingly, "the institutionalization of a hegemonic project in an organic coupling of state and civil society is more important than taking control with the means of production." "155 Infusing ideological and moral elements back into the analysis allows neo-Gramscians to broaden their explanations of how a "historical bloc" is cemented. This is "the synchronic and equilibrated configuration of economic structures as shaped by a paradigmatic set of productive forces and sociopolitical superstructures," which together legitimate a particular social order. ${ }^{156}$

A visible economic nucleus still remains with the development of a transnational bourgeoisie. Although historical contingency begins to be treated more seriously with this relational conception of hegemony, a "residual economism" nevertheless persists. ${ }^{157}$ Such is the case since absent is any mention of the specific discursive practices involved in the establishment of hegemony. This is compounded by the essentialist assumption that hegemony may only be exercised by fundamental classes. However, economic class is but one matrix of differentiation. To endorse it as a privileged category of analysis simply constrains any explanation of the multifarious processes involved in the production of hegemony.

\footnotetext{
${ }^{155}$ Jacob Torfing, "Discourse Theory: Achievements, Arguments, and Challenges," in Discourse Theory in European Politics: Identity, Policy and Governance, ed. David Howarth and Jacob Torfing (New York: Palgrave, 2005), 11.

${ }^{156}$ Bastiaan van Apeldoorn, Henk Overbeek, and Magnus Ryner, "Theories of European Integration: A Critique," in A Ruined Fortress? Neoliberal Hegemony and Transformation in Europe, 37.

${ }^{157}$ Bob Jessop and Ngai-Ling Sum, "Pre-Disciplinary and Post-Disciplinary Perspectives," New Political Economy 6, no. 1 (2001): 89-102.
} 
The manifestation of power is a topic that occupies the agendas of CPE scholars of all stripes. Whether it is primarily located in the constitutive force of transcendental structures and capital or in an ideological domain of false ideas, which defines tangible class interests, power is determined by material conditions. ${ }^{158}$ Capitalist social forces may help mediate the construction of these material structures. As Bastiaan van Apeldoorn notes, "agency in global politics is embedded in the structure of capitalist social relations, and the identity and interests (rather than exogenously given) of any particular actor are thus partly shaped or structured by those relations (original italics). ${ }^{, 159}$ Ultimately, it is the production relations that underpin the structuration of world politics and it is the hegemony of production that explains power and resistance in a particular epoch.

Such a macrostructural account connotes power as something that is possessed and external to the subject rather than being relational and productive of meanings and subjectivities. The main "accumulator" of power in this configuration is the state, which has been captured by class interests. Much of the CPE literature remains, in the words of Jessop and Sum:

wedded to a rather traditional, state-centric view of class hegemony and domination and fails to develop the full implications of Gramsci's concern with civil society and its role in constituting power and hegemony. ${ }^{160}$

This is not to claim that ideational forces trump material conditions. Gramsci may have rejected a transhistorical understanding of power but not the validity of capitalist social relations. However, the "modalities and apparatuses of power" need to be analysed for their

\footnotetext{
${ }^{158}$ Robert W. Cox, Production, Power, and World Order: Social Forces in the Making of History.

${ }^{159}$ Bastiaan van Apeldoorn, Transnational Capitalism and the Struggle over European Integration, 18.

${ }^{160}$ Bob Jessop and Ngai-Ling Sum, "Towards a Cultural International Political Economy: Poststructuralism and the Italian School," 161.
} 
own "conditions of possibility and regularities." ${ }^{161}$ Merely assuming a constant and coherent assemblage of economically functional structures neglects how "economies" are constituted through the deployment of an array of "technical and political interventions, each possessing their own history and material density," or what Deleuze and Guattari refer to as "territorialisation.",162

As alluded to above, the construction of a European fiscal-monetary space is subject to the disciplinary power of transnational finance. Two decades of deregulation and privatisation, endemic to neoliberalism, have disturbed traditional European models of socio-economic structural cohesion. Without doubt, integration itself has generated pronounced conflicts as power is transferred from the level of the nation-state to supranational bodies condemned as being deficient in democratic accountability and procedural efficiency. Although these questions of legitimacy and the scope of authority cannot be ignored, historical materialists posit a more pressing explanation of the SGP predicament. Cafruny and Ryner situate the current crisis within a broader malaise that is aggravated by "the internal contradictions and limitations of neoliberalism and the concomitant subordination to the United States." ${ }^{163}$ In other words, Europe imported a model of macroeconomic management that not only rivals its class interests and subjects it to a foreign hegemonic strategy but which has proven incompatible with its own unique capitalist "regime of accumulation."

Regulation school theorists have operationalised "regime of accumulation" to describe the stabilising order produced when social production is allocated between

\footnotetext{
${ }^{161}$ Nikolas Rose and Peter Miller, Governing the Present: Administrating Economic, Social and Personal Life, 3.

${ }^{162}$ Gilles Deleuze and Felix Guattari, A Thousand Plateaus: Capitalism and Schizophrenia II (Minneapolis: University of Minnesota Press, 1987).

${ }^{163}$ Alan W. Cafruny and J. Magnus Ryner, Europe at Bay: In the Shadow of US Hegemony, 5.
} 
accumulation and consumption. Lipietz submits that it is necessary for such a regime to be:

materialized in the shape of norms, habits, laws and regulating networks which ensure the unity of the process and which guarantee that its agents conform more or less to the schema of reproduction in their day-to-day behaviour and struggles. ${ }^{164}$

As a regulatory programme, the SGP was designed to help regulate fiscal conduct in accordance with monetarist prescriptions. However, it deviated from the embedded conventions to which continental Europe subscribed. Traditionally, to varying degrees, these have included Keynesian-corporatist policies rooted in a Fordist model. With the crisis in Fordism in the 1980s, European governments began to experiment with potential solutions to this problem and adopted neoliberal strategies, which were eventually codified at the supranational level in the form of the Maastricht criteria and subsequently the SGP. ${ }^{165}$ But this transition in the governmental approach to managing the economy was not paralleled by a symbiotic restructuring of the social relations of production underpinning the new regime of accumulation. Elites and publics alike were not prepared to pay the costs of adhering to budgetary criteria that threatened to depreciate their level of welfare.

Imposing an Anglo-American orientation on continental Europe pits it against the German model of "Rhineland" capitalism. Whereas the latter seeks to promote sustainable growth and competitiveness in addition to regional autonomy, the former is geared to exporting a model of hypermobile capital buoyed by US monetary

\footnotetext{
164 Alain Lipietz, Mirages and Miracles: The Crisis of Global Fordism (London: Verso, 1987), 14-15.

${ }^{165}$ Bob Jessop, State Power: A Strategic-Relational Approach, 213.
} 
hegemony. ${ }^{166}$ Unfortunately, Europe is a collection of fragmented fiscal jurisdictions and lacks a centralised budgetary authority (of any relevant size) to adequately manage the externalities stemming from such asymmetry. This inconsistency is aggravated by a fact identified by David Harvey as far back as the early 1980s when he wrote The Limits of Capital. $^{167}$

Financial capital is intrinsically more mobile and volatile than productive capital, which is embedded within the societal and institutional fabric of a nation. Should the capacity of industrial capital to maximise profits and shareholder value diminish or become jeopardised by increasing wages, rigid labour markets or regulation, it will then press to have these obstacles dismantled. However, given industrial capital's dependence on its institutional anchors, its ambitions of fully fledged laissez-faire capitalism will be curtailed by social forces indigenous to their respective national contexts. Typically, this comes in the form of class coalitions and fractions. ${ }^{168}$ Cafruny points to the contradictory nature of EMU by highlighting how the prospects for the "strategic orientation of an embryonic transnational class" were undermined by national class calculations. ${ }^{169}$ Thus, the Ordoliberal form of capitalism is deemed incompatible with the imported AngloAmerican neoliberal variant.

Failures may proliferate in any system, including EMU, and generate antagonisms. For their part, regulationists posit that management expertise is the defining feature of effective government as it attempts to correct these as well as prevent potential market failures. They "challenge the role of the market as the exclusive coordinating mechanism,

\footnotetext{
${ }^{166}$ Alan Cafruny and Magnus Ryner, "A Coming Crisis of the Euro: The Transatlantic Subordination and Social Contradictions of the EMU," 1.

${ }^{167}$ David Harvey, The Limits of Capital (Oxford: Blackwell, 1982).

${ }^{168}$ Bastiaan van Apeldoorn, Transnational Capitalism and the Struggle over European Integration, 29.

${ }^{169}$ Alan Cafruny, "Europe, the United States, and Neoliberal (Dis)Order," 287.
} 
casting doubts on the existence of a 'one best way' for capitalism," which the SGP reference values essentially posit. ${ }^{170}$ As a mode of regulation, the original SGP was believed to mitigate such internal contradictions by separating politics from economics. The fallacy of this rationale is a principal reason for the SGP crisis. Moreover, rather than mitigating the risks presented by these inconsistencies, the SGP actually functions to lock them in. It is not so much an issue of whether this is the appropriate regulatory mechanism for the task at hand as the predicament of artificially cementing this incongruency into the institutional architecture of EMU. But without clearly articulating this conclusion or providing empirical evidence illustrating how the SGP reflects any supposed contradiction, Cafruny and Ryner, as with many CPE accounts, compel the reader to derive his/her own estimations about the governmental implications of such inconsistencies.

Where CPE may prove more effective is in explaining how the structural limitations of EMU produce social dislocation through uneven development. The SGP was deployed as a mechanism designed to render compatible the incompatible demands of market liberalism and social citizenship. To this avail it has failed. Adopting a strict, monetarist regulatory framework, which privileges balance budgets and price stability over redistribution and social solidarity, has translated into sluggish economic growth accompanied by rising structural unemployment for continental Europe. ${ }^{171}$ Germany's:

growth rates for 2001 and 2002 were the lowest of all 15 member-states, and unemployment reached 4 million by mid-2002. Despite relatively high worker productivity ( $2.6 \%$ per year through the $1990 \mathrm{~s})$, the sound money policy prevented a decrease in unemployment. ${ }^{172}$

\footnotetext{
${ }^{170}$ Robert Boyer, "How and Why Capitalisms Differ," Economy and Society 34, no. 4 (2005): 509.

${ }^{171}$ Martin Rhodes, "'Varieties of Capitalism' and the Political Economy of European Welfare States," 363-70.

${ }^{172}$ Alan Cafruny and Magnus Ryner, "A Coming Crisis of the Euro? The Transatlantic Subordination and Social Contradictions of the EMU," 8.
} 
Efforts to stimulate post-industrial employment face governmental challenges as countercyclical deficit financing - commonly employed to remedy such economic conditions has been stripped away as an accepted tool. Together with niche strategies that generate games of "competitive austerity" the uneven effects of EMU on the capacity of classes and states to respond are only compounded by the absence of any comprehensive form of European macroeconomic management. ${ }^{173}$ Differentiated patterns of development result, which infuse further asymmetry into the system.

An "organic crisis" of the European social model materialises because within this regulatory framework "Europe has failed to achieve the new socio-economic trajectory of capital accumulation that would be necessary to stabilise its individual social formations." ${ }^{\prime 174}$ Member States are prevented from ameliorating rising unemployment and inducing productivity growth compatible with their norms of social citizenship.

Instability festers as public spending and social security - traditionally compensating elements in times of market failure - are slashed. This provokes a volatile politics of reform and culminates in crises, such as the 2003 Ecofin debacle. We move into what Jessop labels as a Schumpeterian Workfare Post-National Regime (SWPR) with the denationalisation of the state and the destatisation of politics. ${ }^{175}$ Further economic liberalisation is advocated as the solution to market externalities and social dislocation. Subsequently, there is a crisis of legitimacy. Without a centralised fiscal polity, EMU lacks the necessary political anchor to adequately govern this fiscal-monetary space of asymmetric fiscal relations and structural limitations.

\footnotetext{
${ }^{173}$ Alan W. Cafruny and J. Magnus Ryner, Europe at Bay: In the Shadow of US Hegemony, 10.

${ }^{174}$ Alan Cafruny and Magnus Ryner, "A Coming Crisis of the Euro? The Transatlantic Subordination and Social Contradictions of the EMU," 21.

${ }^{175}$ Bob Jessop, State Power: A Strategic-Relational Approach, 210.
} 


\section{Critical Political Economy: The Critique}

Derrida once commented that Marxist endeavours to unearth a realm of authenticity from which all social phenomena was derived, actually failed to resolve the question of "how to distinguish between the analysis that denounces magic and the counter-magic that it still risks being. ${ }^{1176}$ Although recent CPE literature has moved beyond the limits of the basesuperstructure theoretics of vulgar Marxism and come to experiment with social relations, grand theorising remains a defining feature of the majority of $\mathrm{CPE}$ contributions seeking to explain EMU/SGP. Attempts at a methodologically sound ontological and epistemological conceptualisation of European economic integration fail to problematise the "economy" or acknowledge the historical contingency of the SGP problematic. Instead, we witness the reabsorption of the political economy of EMU within some purported "objectivism." To this effect, various mutations of the Marxist tradition have, arguably, adopted "witchery" in their efforts to conjure up a parsimonious exposition of a universal reality, to which EMU belongs; anchored in a given economic domain but divorced from its techniques of truth production. None of these have been very successful. Indeed "the history of the Marxist imagination is characterised by a tendential ebbing and flowing between the idealist search for certainties and their persistent denial by the political. ${ }^{, 177}$ Dubious theoretics translated into disastrous political programmes work to undermine CPE insights into the Ecofin crisis and limit their appraisal of EMU governance more broadly speaking.

My critical analysis of this CPE literature is arranged according to the following division of labour. First, I shall continue to challenge the structuralism and reductionism

\footnotetext{
${ }^{176}$ Jacques Derrida, Specters of Marx: The State of the Debt, the Work of Mourning, and the New International (New York: Routledge, 1994), 47.

${ }^{177}$ Glyn Daly, "The Political Economy of (Im)Possibility," in International Political Economy and Poststructural Politics, ed. Marieke de Goede (New York: Palgrave Macmillan, 2006), 180.
} 
located within the broader historical materialist approach to European integration. Whether it is explaining structural change or in regards to the relational force of hegemony, an economic determinism is persistently visible. Subsequently, dissolving power into the economy or class relations also has adverse effects on the conceptualisation of subjectification. An overemphasis on structural power makes CPE inattentive to the variability and contestability of modes of subject formation.

This discussion leads into the next point of contention; namely a broader evaluation of how power is conceptualised by this school of thought. At its core there is an a priori economic notion of power which is divorced from the very techniques of knowledge production. Though neo-Gramscians profess to move beyond the purely material dimension of power and embrace moral-intellectual leadership in civil society, they fail to depart from a macroscopic, possessive and class-based conceptualisation of power manifested in the state. Lastly, I argue against the blatant "capitalocentricsm" prevalent throughout this literature. A summation of this tendency will precede my concluding remarks.

Although CPE contributions have provided some insight into the macrohegemony of EMU governance, the literature remains largely structuralist and reductionist in its reading of EMU. Ultimately limited to one fundamental form of space, namely the capitalist market, this rational substratum is said to inform the constitution of EMU agency. Though the object/subject dichotomy may collapse with such a dialectical reading, CPE's engrossment with economic determinism blinds it to the micro-technologies of power that create and promote new geographies of influence by normalising the objects and subjects of governance. Presenting the subject as the medium of the relations of 
production reduces subject formation to the planes and functions that engender it. ${ }^{178}$ Not only is this a misleading, epiphenomenalist account but it is by no means an absolute position unique to capitalism(s). While concepts are framed and develop in a political space, they are not inevitably reducible to the particularities of that space. Nevertheless, such determinism and path dependency have been reified in CPE approaches to EMU. The consequence is a poor understanding of how this spatial-temporal order is constituted and organised through the heterogeneous exercise of power. Without an adequate knowledge of the discursive construction of EMU or how the asymmetric application of SGP statutes conditions how it becomes a problem of governance, CPE advances a notion of social reality saturated in essentialist capitalism.

Continuously privileging the structural over the ideational or relational, what Pistor labels as "structural cohesion," neglects how the SGP, as a mode of regulation, has been “constituted through the often contradictory activities of class-based and other actors, and which has to be seen as 'historically contingent." ${ }^{179}$ Furthermore, it detracts from CPE's explanatory value as it hinders the development of an adequate conceptualisation of agency. EMU is not only the articulation of social collectives but of a plurality of individual actors as well. The power that Trade Commissioner Pascal Lamy exercised by describing the SGP as "medieval" and calling for its reformulation cannot simply be reduced to class orientation. ${ }^{180}$

\footnotetext{
${ }^{178}$ Nikolas Rose and Peter Miller, Governing the Present: Administrating Economic, Social and Personal Life, 4.

${ }^{179}$ Marcus Pistor, "Agency, Structure and European Integration: Critical Political Economy and the New Regionalism in Europe," in The Political Economy of European Integration: Theory and Analysis, ed. Erik Jones and Amy Verdun (New York: Routledge, 2005), 114.

${ }^{180}$ Alan Cafruny, "Europe, the United States, and Neoliberal (Dis)Order," 293.
} 
Deciphering what kind of economy of power Europe is implicated in requires an understanding of the how subjectivity is constituted by the multiplicity of forces acting on it. However, most CPE analyses are deficient in this respect because "they lack a theoretically informed explanation of the relationship between economic structures and class-based political agency and strategy." ${ }^{, 181}$ Neo-Gramscians, such as Cafruny and Ryner, may strive to transcend the dogmatic structuralism of Marx and Althusser by reintroducing politics as the struggle for hegemony. Yet, all too often their arguments deteriorate into functionalist explanations of the state. The state is presented as a logical necessity reduced to a set of functions that promote and maintain (transnational) class fractions. Its power is the material condensation of an order derived from class struggle. We are reminded that "it is above all the nation-state that maintains societal legitimacy by mediating the tendentially antagonistic relations between classes (original italics)., 182

In the case of EMU, it is argued that conflicting national class interests prompted states to trigger the SGP crisis. At once, the state is presented as both the culmination of the logic of production relations and as an instrument of class rule. The latter implies a calculating subject in which power is legitimated at the centre. For its sake, legitimacy is connected to the symbolic logic of hegemony, which has a political character. But contending, as Rhodes does, that political upheavals are generated by dysfunctional productive regimes in Member States restricts explanations of the SGP crisis to the literal economic domain. ${ }^{183}$ Laclau and Mouffe, however, deconstruct this line of argumentation

\footnotetext{
${ }^{181}$ Marcus Pistor, "Agency, Structure and European Integration: Critical Political Economy and the New Regionalism in Europe," 108.

${ }^{182}$ Alan W. Cafruny and J. Magnus Ryner, Europe at Bay: In the Shadow of US Hegemony, 18.

${ }^{183}$ Martin Rhodes, "'Varieties of Capitalism' and the Political Economy of European Welfare States."
} 
to reveal that any antagonism "overflows its own literality." "184 This contradiction is not resolved by neo-Gramscians since:

even though the diverse social elements have a merely relational identityachieved through the articulatory practices- there must always be a single unifying principle in every hegemonic formulation, and this can only be a fundamental class (original italics). ${ }^{185}$

Again, we return to the economy as the essential structure underpinning all social relations. From this, historical materialists deduce the state and state power in terms of their own inherent and pre-given properties.

This privileges the notion of a unitary state exercising juridical authority. Limited to sovereign power in the construction of agency not only neglects other forms of power, such as disciplinarity or control, but misconstrues agency and interests. Marieke de Goede recognises this deficit, noting that:

economic agents do not act purposefully and deliberately in the service of particular class interests, but emerge within a domain of explicit and implicit norms, which regulate the limits of the sayable for legitimate participation in economic practice. ${ }^{186}$

Issues of identity and the politics of representation are strikingly absent from most CPE perspectives. In particular, the question of the standardisation of normalcy as a fundamental norm according to which subjectivity and strategy were (and continue to be) devised in the SGP crisis is ignored.

Whether actors adhered to the established reference values, ascertained if they were deviating from the norm and therefore what therapeutic measures were appropriate

\footnotetext{
${ }^{184}$ Ernesto Laclau and Chantal Mouffe, Hegemony and Socialist Strategy: Towards a Radical Democratic Politics (London: Verso, 1985), 11.

${ }^{185}$ Ernesto Laclau and Chantal Mouffe, Hegemony and Socialist Strategy: Towards a Radical Democratic Politics, 69.

${ }^{186}$ Marieke de Goede, "Introduction: International Political Economy and the Promises of Poststructuralism," 10.
} 
to correct such delinquency. Under a strict rules based system, such as the original Pact, these types of risks were readily discernable. With the 2005 SGP reforms, the detection of misconduct relies even more on the discursive practices of representation. As the probabilistically mechanical assessment of fiscal behaviour is displaced, "representations of economic categories become essential to render economic practices effective and possible (original italics). ${ }^{, 187}$ Expertise must now adjust to process these representations of uncertainty through which agents become constituted. This comprises a continuous renegotiation of subjectivity and interests as the representation of normalcy becomes more politicised under a government through uncertainty.

Concentrating on the programmatic dimension of the SGP reveals a mode of representation that rarely exemplifies the smooth functioning regulatory system imagined by regulation school inspired CPE scholars. Although the technocratic sphere is significant in establishing a codified and formalised body of knowledge regarding European economic practices, risk governance is more than a purely technical practice. It embodies values about transparency and responsibility, which have become synonymous with normal conduct and efficient organisation. Substantial "effort has been expanded on making risk management into a value proposition and in both private and public sectors the concept of risk is being enrolled in a new focus on outcomes and performance (original italics)., 188 Affixing the right labels to EMU activities performs a programmatic role "which connects concrete technical routines to the ideals which give them value." 189 Acceptance of these

\footnotetext{
${ }^{187}$ Magnus Ryner, "International Political Economy: Beyond the Poststructuralist/Historical Materialist Dichotomy," in International Political Economy and Poststructural Politics, ed. Marieke de Goede (New York: Palgrave Macmillan, 2006), 143.

${ }^{188}$ Michael Power, The Risk Management of Everything (London: Demos, 2004), 13. This reflects the emphasis which neoliberal doctrine places in an unfettered market geared to minimizing dangers to profit maximization.

${ }^{189}$ Michael Power, The Audit Society: Rituals of Verification (New York: OUP, 1999), 8.
} 
rationalisations and their descriptive practices legitimises the SGP as a normal practice and field of knowledge within the EU. This has the effect of shifting the locus of power away from the central state or class to liberal technologies of indirect influence, which renders the neoliberal inspired EMU visible in novel ways. Unfortunately, CPE explanations are devoid of any serious analysis of how the SGP governmental apparatus helps induce forms of self-regulation through risk or uncertainty-based modes of representation aside from references to the coercive capacity of capital.

By speaking of a single coherent space (i.e. capitalism) without adequately problematising the heterogeneous techniques and discourses involved in the strategic codification of power, historical materialists reify it while constraining themselves to socio-economic notions of agency. All too frequently they subscribe to the idea of EMU or the state as a universal container or structure in which subjects are "situated" or "embedded." Yet, aside from the erroneous oversight of historical contingency, these CPE accounts fail to acknowledge that the very idea of absolute space is itself a social construction. Paraphrasing Smith and Katz, Gibson-Graham caution(s) that:

by proliferating spatial metaphors without problematizing the representation of space, social theorists reproduce a view of space that is "politically charged in its contemporary implications as much as its historical origins. ${ }^{, 190}$

This may have the effect of sanctioning the theoretical status-quo and a structural coherence which in fact does not exist.

Assigning explanatory value to the internal inconsistencies of a fictitiously uniform space in order to account for the SGP crisis is even more precarious. As such, it is vital to understand how spatial-temporal orders like EMU are constructed and for what

\footnotetext{
${ }^{190}$ J.K. Gibson-Graham, The End of Capitalism (As We Knew It): A Feminist Critique of Political Economy, 74.
} 
purpose. Unpacking and displacing capitalism, in all its forms, as well as its supposed protector, the state, allows us to actually transcend the economic determinism located in historical materialist analyses of EMU integration and possible disintegration. Through such an exercise, we are in a better position to understand how the relations between SGP subjects and orders are conceived and conditioned as a problem of government.

Without adequately dissecting the mutual constitution between economic structures on the one hand and class interests and strategies on the other, historical materialists treat this relationship as direct and unproblematic. ${ }^{191}$ As I have argued, their attempts ultimately rest on reductionist and structuralist explanations of EMU integration. What they omit by privileging the macrosocial material realm of production is the discursive and contingent nature of power. Power is not a priori but rather:

immanent and relational- it has no ultimate ground beyond specific technologies of power and their articulation to knowledge...CPE misses the mechanisms and struggles involved in the strategic codification of power relations and the development of governmental rationalities that provide the basis for emergent and provisional macrosocial order. ${ }^{192}$

Power relations need to be investigated wherever they emerge and not solely at capitalist sites, as it is there that the normalisation of agency occurs. Being immanent in every social relation, power is not the possession of material resources or necessarily the repression of labour; though the codification of particular relations may precipitate such a state of affairs. To speak of states or firms seizing power as if a commodity external to subjects is to neglect that power is the constituting force of different forms of subjectivity. It is historically contingent.

\footnotetext{
${ }^{191}$ Marcus Pistor, "Agency, Structure and European Integration: Critical Political Economy and the New Regionalism in Europe," 123.

${ }^{192}$ Bob Jessop and Ngai-Ling Sum, "Towards a Cultural International Political Economy: Poststructuralism and the Italian School," 163-65.
} 


\subsection{Certainly Not the Last Word}

Historical materialists neglect that government is a matter of representation and overemphasise government as a form of intervention. The economy, however, does not exist outside of the discursive practices of representation. Conversely, constructivists often privilege the ideational without adequately explaining how it conditions agency or material realm. False dichotomies, the absence of a genuine theory of interest or agency, and propositions removed from the empirical reality, which they seek to study, are all symptoms of liberal intergovernmentalism as well. Voluminous as mainstream contributions have been to the discipline of $\mathbb{R}$, they have provided lacklustre explanations of problematic in question.

These deficits are exposed through an analysis of three principal pillars of contestation. In addition to subscribing to fictitious dualities and linear histories, conventional accounts demonstrate an over reliance on economistic conceptions of power that compel them to neglect the discursive constitution of this emerging fiscal-monetary space. But EMU is rendered "real" by the very techniques used to translate political rationalities into one of the most formidable challenges EMU has thus experienced; the SGP crisis. To discount the relational, and therefore discursive, nature of European political economy is to deny the connection between its cognitive, moral and material dimensions in favour of static representations which lack a basis in reality.

A new analytical instrumentality is required to avoid such deficient explications. In the forthcoming chapter, I introduce the governmentality approach as an alternative framework that can help us to appreciate how uncertainty-based rule is articulated through political mentalities and their associated programmes in the aftermath of the 2003 Ecofin 
crisis. Equipped with a set of analytical tools, I then diagnose how the actual crisis, together with subsequent reforms, has opened up new political, legal, and economic spaces of governance within EMU in the effort to monitor and manage contingency. Uncertainty, as a mode of governance, introduces a dimension of creative entrepreneurialism lacking with risk while simultaneously refocusing responsibility around variegated notions of normalcy, which may help promote budgetary discipline and fiscal ownership. 


\section{Chapter 3 Analytics of Government}

Confronted with a barrage of hazards, ranging from fiscal profligacy to an asymmetrical application of community standards to the liabilities associated with an ageing population, EMU is consistently thwarted by a stream of failures that undermine its sense of control. One of the most prominent and damaging of these instances was the 2003 SGP crisis. It revealed particular conceptual, ideological, and institutional inconsistencies in the organisation of EMU that have amplified the politics of fiscal governance. This (re)politicisation is reflected in and magnified by the transition from a risk dominant system of management to the government through uncertainty. Recognising the problems of budgetary regulation through the prism of uncertainty, policy-makers are more inclined to privilege qualitative, non-probabilistic prescriptions anchored in subjective forms of expertise and critical judgement rather than strictly quantitative risk metrics. My dissertation examines this transition in modalities of rule.

Again, rather than characterising this shift in absolutist terms, it is preferable to understand it as a matter of degree. Although questions regarding the utility of risk-based forms of rule may compel authorities to reassess their application, they still comprise a vast segment of the organisational infrastructure of EMU. Nevertheless, the revival of a politicised "French" approach to fiscal relations, embodied in the Lisbon process, has exposed this trinity of inconsistencies in regulation this emerging space through risk. The response, in the shape of the revised 2005 Pact, signals a change in how this spatialtemporal order is problematised and governed. Uncertainty is increasingly being deployed as a technique to help induce the internalisation of self-regulation thereby fostering the compliance necessary for economic stabilisation and EMU coherence. 
It is not astonishing that a severe episode of this magnitude has attracted analytical expositions from all over the field of IR. Unfortunately, the majority of conventional accounts do not problematise how interrelations define and condition a discursive formation like the SGP; namely the link between the rationality and the mechanisms of government. They treat risk and uncertainty as self-evident, monolithic technologies and in the process reinforce a fictitious subject/object dichotomy. Uncertainty is typically conceptualised as an unknown risk. With more information or better computational systems, it is subsequently transformed into risk, which makes it tractable to the kind of rational choice modelling underpinning IG. However, lacking the comparative normality from which to assign a superior outcome, rational choice models are incapable of telling us what to do. Nor do they account for the construction of normalcy as a precursor for convergence. For this purpose, a new analytical instrumentality is necessary; governmentality serves this purpose.

An analytics of government seeks to disentangle ideologies and what is portrayed as supposedly totalising and monolithic in order to redress the deficiencies in our understanding of EMU resulting from the shortcomings of conventional IR theories. By deploying the analytical tools introduced below, it is possible to refine some of the more persuasive and intellectually rigorous insights offered by these accounts while expanding our knowledge of how this novel fiscal-monetary space is constructed and regulated. This is not a "theory" of governmentality concerned with the kind of grandiose proclamations characteristic of much of the IR literature. Rather, governmentality is an empirically-based analysis of the various styles of government that populate the entire terrain of international politics; including EMU. Without being impeded by all the false 
dichotomies and theory-based burdens afflicting traditional explanations, we are better equipped with the necessary tools to come to terms with the very conditions necessary for the actualisation of all kinds of governed relations.

Whereas all the mainstream theories directly or implicitly advocate a normative position derived from questionable or underdeveloped epistemological foundations, governmentality allows us to problematise how normalcy has been appropriated in the context of EMU and for what purposes. Such an interpretative disposition is sensitive to the multiple ways that economics (and in particular contingency) is performative in the constitution of the reality it seeks to describe. How uncertainty - or risk for that matter contributes to the production of subjects and objects of government is virtually neglected by conventional IR theories. Instead their appetite for accurately representing an a priori underlying reality compels them to register evidence for such a foreordained conclusion. Positivistic levels of analysis claim to unearth the fundamental reality upon which social relations are based. Mapping out the organisational practices, discourses, interests and institutions involved in managing uncertainty is significant because it disturbs the notion of EMU as an immobile and unified structure. We are then in a more suitable position to recover the changing meaning of EMU with its identifiable parameters, power systems, and mentalities of rule.

Quite often these mainstream approaches succumb to the risk of an attribution bias, which grants EU-level variables a presupposed degree of significance and state institutions a legitimacy as objects of study. ${ }^{1}$ State-centrism of this sort is commonly found in both IG and constructivism. Governmentality minimises this common fallacy by disturbing the

\footnotetext{
${ }^{1}$ Kenneth Dyson, "The First Decade," in The Euro at 10: Europeanization, Power, and Convergence, ed. Kenneth Dyson (New York: Oxford University Press, 2008), 29.
} 
unequivocal primacy of the state as the unit of analysis in order to understand how the specific construction and interpretation of risk or uncertainty in the SGP differ from meanings attributed to them in other spaces. The performativity of uncertainty "is not to represent what was previously unrepresented, but try and reorganise the circulation and control of representations." ${ }^{2}$ By arranging relationships according to inclusive-exclusive categories, uncertainty acts as a "boundary object" immanent in strategies of control.

The temporary stabilisations that result are neither uniform nor constant but historically contingent and contestable. In these configurations of power, EMU is itself understood as a "calculating device where sociotechnical algorithms organise and, very often, facilitate encounters between agents endowed with unequal calculating capacities."3 An assemblage forms that privileges an authoritative logic - or leverage - of self-enforced regulation. These networks are assembled through the inclusion of actors, organisations and techniques into larger macro affiliations. One of their defining characteristics, which binds them together, is a similar problematisation of their interests. When concurrent and consonant, this reflexivity produces a flexible and mobile alignment intent on the actualisation of the network's ambitions. This is simultaneously bolstered by discursive practices of internal and operational control and a field of governmentality which aligns freedom with creative entrepreneurialism. What results is a form of "metagovernance" that modulates fiscal conduct across a variety of domains in relation to established norms and rationalities.

\footnotetext{
${ }^{2}$ Timothy Mitchell, "The Properties of Markets," in Do Economists Make Markets? On the Performativity of Economics, ed. Donald MacKenzie, Fabian Muniesa, and Lucia Siu (Princeton: Princeton University Press, 2007), 267.

${ }^{3}$ Michel Callon, "Performative Economics," in Do Economists Make Markets? On the Performativity of Economics, ed. Donald MacKenzie, Fabian Muniesa, and Lucia Siu (Princeton: Princeton University Press, 2007), 348.
} 
Whereas IG or CPE posit a universalistic account of reality where power is treated as a commodity, my genealogy problematises defined boundaries by tracing the lineage of inscription in order to provide the comparative normality necessary to ascertain how truth claims are constructed. This involves politicising their limits, the power relations that constitute these and the methods through which they are articulated. Power is not "appropriated as a commodity" but centrifugally circulating through a "net-like organization." 4 It may be reconceptualised within what Laclau and Mouffe refer to as "discursive relations." Rather than emanating from a "sovereign centre" or social sphere (i.e. economic), "any discourse is constituted as an attempt to dominate the field discursively, to arrest the flow of differences, to construct a centre." ${ }^{6}$ Hegemonic discourses arise from the strategic codification of power relations and challenge the notion of "discursive idealism" without a connection to the material world. How this transpires is better understood through analytics of government which helps us connect the definition of boundaries to the mechanisms that entrench them.

As the lineages connecting this (uncertainty-based) EMU apparatus with its technoscientific epistemology become evident, governmentality reminds us that how truth claims are produced and legitimated depends on their articulation to a political imagination. This is achieved through the deployment of discursive practices (e.g. speeches, mechanisms, institutions). How government through uncertainty mobilises a leverage of

\footnotetext{
${ }^{4}$ Michel Foucault, "Two Lectures," in Power/Knowledge : Selected Interviews and Other Writings, ed. Colin Gordon (New York: Pantheon, 1980), 98.

${ }^{5}$ Ernesto Laclau and Chantal Mouffe, Hegemony and Socialist Strategy: Towards a Radical Democratic Politics (London: Verso, 1985), 112; although several of their arguments are introduced in my critique of historical materialism, I wish to caution the reader about adopting all of Laclau and Mouffe's propositions. Not all of their ideas are conceptually sound. Yes, they may shed light on the articulation and embedding of governmental rationalities through nonessentialist forms of power. However, their conflation of ideas and discourses as well as material and nonmaterial power detracts from the thrust of their thesis.

${ }^{6}$ Ibid.
} 
control to condition the very discursive constitution of agency and interests is then revealed at all the sites rather than just at the sovereign level. Within these sites, discourses are "lodged...in particular technological devices and the knowledge and skills required for their use." ${ }^{, 7}$ By clarifying what "constitution" actually entails - something lacking in IG and constructivist accounts - governmentality presents a more coherent theory of agency without overemphasising either social structures or privileging the material over the ideal, such as much of CPE. As a result, it is a better framework for coming to grips with the contestability and variability of modes of subject formation that conventional IR theories neglect.

Of course, macroscopic analysis may offer certain insights into relevant themes occupying IPE. Questions of how post-Fordist regimes of capital accumulation manipulate spatial parameters to guarantee their reproduction ${ }^{8}$ or how Europe's asymmetric governance structure privileges particular transnational interests through the production of a "free space for capital" draw our attention to struggles emanating from the structural terrain of capital formation. Unfortunately, these conflictual circuits of capital accumulation and their corresponding modes of regulation are typically embedded in a stable statist model and/or intrinsic features of capitalism itself. Ontological totalities are presupposed and, as I argued above, the mutual constitution between the material and the discursive - conceptualised as the dialectic between expertise and politics - is seldom problematised. Together with realist paradigms that champion anthropomorphic understanding of the nation-state, such IR approaches are hostage to ontological

\footnotetext{
${ }^{7}$ Jef Huysmans, The Politics of Insecurity: Fear, Migration and Asylum in the EU (New York: Routledge, 2006), 92.

${ }^{8}$ David Harvey, The Limits of Capital (Oxford: Blackwell, 1982).

${ }^{9}$ Kees van der Pijl, “A Lockean Europe," New Left Review 37 (2006): 32.
} 
conundrums that limit their ability to grasp the contingency implicit in the performativity of practice.

In short, outstanding ontological questions handicap the potential contributions of conventional accounts. Bracketing such ontological queries opens up new lines of investigation about the conditional dimensions of governing through uncertainty. Neither hostage to explicit nor implicit forms of capitalocentricsm, nor also to an artificial linearity of history, an analytics of government disentangles the performative practices which constitute the historically contingent stabilisation known as EMU. Power is exercised through the fabrication of these particular forms of subjectivity. Understood as a productive force, power flows in localised sites to establish its own objects of government. By analysing its operation in these defined quarters, we are better positioned than mainstream theories to understand how uncertainty enables an enterprising mentality in EMU subjects who are located within fields of regulated discretion devised by the 2005 reforms. This is accomplished through inscriptive technologies of rule that condition the representation of fiscal profligacy, derived from cues of normalcy, as a problem of government to which uncertainty is presented as a solution.

In this chapter, I introduce the theoretical core of the analytics of government in order to redress some of the more glaring deficits located in the IR literature. I begin with a presentation of the conceptual-empirical orientation which informs the remainder of my analysis. As a set of analytical tools, governmentality helps us understand how expertise is transforming through the (re)politicisation of fiscal management. To recover what this reabsorption of the technocratic into the political means for European political economy, two themes comprise this diagnostic approach. First, governmentality has a 
"deconstructive" property. It helps us understand the SGP problematic by focusing our attention along three principal axes where governance occurs:

1) the discursive definition of boundaries, or the production of truth;

2) the technologies of power in which subjects are implicated and the methods of their subjectification;

3) the mentalities of rule which underpin regimes of authority.

Investigating these three dimensions of the SGP puzzle illustrates how uncertainty conditions the re-imagined spatial-temporal configuration of governance and valuation in the wake of the SGP crisis. I explicate the manner in which these analytical tools are deployed to illustrate how the SGP it is made intelligible as a form of reason identitive of uncertainty and interwoven into the European political imagination and discourse. Without doubt, the very regulatory context of EMU and its means of surveillance have been altered and this is reflected in these areas.

Second, there is a "reconstructive" thematic to this dissertation. Governmentality directs our attention to the diverse set of the narratives, technologies and programmes involved in the restitution of this novel fiscal-monetary space after its near collapse. Interrogating these various sites where governance takes place reveals a panalopy of new calculative practices engaged in the continuous construction of EMU. A critical ontology elucidates this performative capacity of uncertainty to construct the social reality it seeks to describe, thereby providing us with insights into the changing relationship between expertise and politics that conventional IR theories cannot offer. Uncertainty facilitates the temporal territorialisation of new planes of power in the SGP according to a reconceptualisation of normalcy. Vectors of normalcy inform how these different parameters of EMU are devised in the effort to foster convergence. No longer restricted to only the state and sovereign power, this encapsulates creative entrepreneurialism within 
new forms of regulated freedom across time and space. At once, the symbiotic relationship between the deconstructive and reconstructive elements of the governmentality approach is demonstrated.

Third, I discuss how risk and uncertainty constitute key questions about modes of governance. Understood as a complex category aimed at addressing the problems of variability in governing this fiscal-monetary space, uncertainty helps define EMU according to various logics of control and responsibility that differ from risk. In the process, we come to understand the transition in rendering the SGP thinkable and susceptible to the (re)politicisation of fiscal relations through a governmental modality underscoring contingency. Finally, in the concluding paragraphs, I outline a plan of deployment whereby these analytical instruments help mobilise a clear notion of the performative power of uncertainty as a dominant modality of rule.

\subsection{The Deconstructive Analytics of Managing EMU}

How have fiscal politics captured the imagination of the architects of EMU to become a problem of government? In particular, how is expertise being transformed in the aftermath of the SGP crisis and what are the ramifications for the regulatory design of EMU? Accordingly, what is the regulatory capacity through which risk and uncertainty are delivered as solutions to the problems which they represent? All these questions address the spatial and temporal contingency and variability of representing and acting on fiscal relations. Their substantive explanations are not as compelling as the statements they make about the imaginative horizon of contemporary mentalities of rule when faced with an indeterminate future. In this context, I am interested in how EMU appropriates uncertainty in the effort to condition the spatial-temporal dimensions of managing in the name of 
normalcy in order to promote convergence. A deconstructive ethos proves quite informative in exposing this changing fiscal landscape of Europe as it helps us overcome the deficits present in traditional explanations.

\section{Truth Techniques}

Although the "potency of ideas...lie in their influence in shaping choices and not necessarily in their leading to successful outcomes," socially constructed truths cannot be divorced from the institutional and cultural practices that allow them to materialise. ${ }^{10}$ Too frequently the study of truth techniques has remained peripheral in IR whereas the study of ideology has gained ascendance. Just as troubling is the tendency on the part of certain postmodern approaches to implicitly embed discourse by primarily concentrating on the statements of politicians or bureaucrats at the expense of the technical infrastructure through which they are delivered and realised. My dissertation seeks to redress these tendencies by shifting attention to the actual practices that condition how EMU governance becomes a problem for policy-makers. This entails an analysis of the discursive rationalities of EMU as well as the technologies of government through which "authorities seek to embody and give effect to governmental ambitions."11 Arguing that knowledge is discursively mediated, I challenge the a priori facticity underpinning the false dichotomies found throughout much of the IR literature.

Before policies may be enacted, some intelligible comprehension of what is within the realm of possibility, and what is considered incredulous, must exist; otherwise known

\footnotetext{
${ }^{10}$ Ravi K. Roy, Arthur T. Denzau and Thomas D. Willet, "Introduction: Neoliberalism as a Shared Mental Model," in Neoliberalism: National and Regional Experiments with Global Ideas, ed. Ravi K. Roy, Arthur T. Denzau and Thomas D. Willet (New York: Routledge, 2007), 5.

${ }^{11}$ Peter Miller and Nikolas Rose, "Political Power beyond the State," British Journal of Sociology 43, no. 2 (1992): 175.
} 
as the production of "truth." Foucault contends that the very parameters which delimit our understanding of surrounding empirical phenomena are intricately connected to the circulation of "apparatuses of knowledge, which are not ideological constructs" but embedded within the materiality of discourse. ${ }^{12}$ As preconditions for any kind of action, these formulations of facticity are derived from techniques of truth production, which include "methods of observation, techniques of registration, procedures of investigation and research, apparatuses of control."13 Through the deployment of discursive practices, such as benchmarks and statistics, a regulatory space known as EMU forms, which is neither static nor a uniform totality but amenable to the changing articulations of managing an uncertain future.

An analytics of government allows us to arrive at a better understanding how this plays out in Europe. Governmentality:

seeks to identify these different styles of thought, their conditions of formation, the principles and knowledges that they borrow from and generate, the practices that they consist of, how they are carried out, their contestations and alliances with other arts of governing. ${ }^{14}$

Rooted in the Foucauldian tradition of deconstructive critique, genealogies help ascertain how truth claims are constituted by dissecting the very discourses, institutions and technologies employed in their actualisation. Such an analytical and diagnostic exercise sheds light on the institutional construction of knowledge and how it is appropriated to serve defined governmental ambitions.

In this study, I am interested in deciphering the lineages that demonstrate how uncertainty has constructed both an analytical and socio-economic space which conditions

\footnotetext{
${ }^{12}$ Michel Foucault, "Two Lectures," in Power/Knowledge: Selected Interviews and Other Writings, 102.

13 Ibid, 102.

${ }^{14}$ Nikolas Rose, Pat O’Malley and Mariana Valverde, "Governmentality," Annual Review of Law Social Science 2, no. 5 (2006): 5.2 .
} 
the way policy-makers think about and govern fiscal conduct. This conceptualisation of uncertainty - as well as risk - in the constitution of EMU is contingent upon the politics of representation or truth production. Discourse is a "technology of thought" that enables an economy to be "political" as competing claims produce the accepted "truths" that it is founded on. ${ }^{15}$ Normalcy, being discursively mediated, represents a particular condition to the exclusion of alternative understandings of legitimate budgetary conduct. Alterity becomes visible through this deconstructive ethos of governmentality.

Government is a problematising activity which helps orient subjects by presenting social phenomena in terms of various puzzles that need to be addressed and solved. How these problems are represented is dependent on the domain in which they are articulated. Political discourse is that domain. Here fiscal profligacy is problematised as an abnormality through the discourses of "good times" and "national fiscal ownership." These embody contested representations of correct conduct and, being social constructions, they challenge what is presented as "self-evident" and as the "natural" order of things. By dissecting how the representation of normality is socially manufactured through deliberate, rather than determining, technologies of truth production, we "open up technical and depoliticized economic practices to political scrutiny." of international/domestic, public/private or subject/object common in conventional IR accounts. Now the legitimacy of these normative claims may be revaluated in relation to their contextual histories, with potential implications for the relationship between politics

\footnotetext{
${ }^{15}$ Peter Miller and Nikolas Rose, "Governing Economic Life," Economy and Society 19, no.1 (1990): 5.

${ }^{16}$ Marieke de Goede, "Introduction: International Political Economy and the Promises of Poststructuralism," in International Political Economy and Poststructural Politics, ed. Marieke de Goede (New York: Palgrave Macmillan, 2006), 7.
} 
and expertise; not to mention the multiple other fields where there is a deliberate attempt to act on the world around us.

Once rigid "enclosures," accessible only to specialised networks of experts, such as the technocratic ECB Executive Board or the EFC, these governmental domains become susceptible to even the most pedestrian of judgement; consecutively working to undermine expert "hope that problems of regulation can remove themselves from the disputed terrain of politics and relocate onto the tranquil yet seductive territory of truth." ${ }^{, 17}$ In this sense, the notion of an unproblematic reality is questioned as deconstruction discloses expert and political complicity in the representational process. Thus:

it challenges closure...first, by affirming the contestable character of its own projections, second, by offering readings of particular features of contemporary life that compete with detailed accounts offered by others, and, third, by moving back and forth between these two levels as it introduces alternative interpretations onto the established field of discourse. ${ }^{18}$

Governmentality provides us with a comparative normality, which IG models lack under conditions of uncertainty, while adding a vital methodological element absent in constructivist efforts to explain the constitution of knowledge. Practices of representation/ truth production embody a performative element that delimits the discursive constitution of EMU as an object of government. This dissertation examines the role uncertainty plays in this production of such boundaries and the sedimentation of its institutional infrastructure.

\section{Technologies of Power}

My intention is to begin with what Laclau and Mouffe identify as discursive "nodal points," through which knowledge and meaning are framed. Then I proceed to develop a

\footnotetext{
${ }^{17}$ Nikolas Rose and Peter Miller, "Political Power beyond the State," British Journal of Sociology 43, no. 2 (1992): 188.

${ }^{18}$ William Connolly, "The Irony of Interpretation," in The Politics of Irony: Essays in Self-Betrayal, ed.

Daniel W. Conway and John E. Seery (New York: St. Martins, 1992), 147.
} 
more thorough dissection of the specific regulatory technologies where power relations emerge and the form they assume. That being said, a hegemonic discourse, namely new monetarism/neoliberalism, was challenged and fragmented by the Ecofin crisis, which cannot be dismissed as simply whimsical. As opposed to reducing the problematic to sovereignty, or class consciousness, a better approach is to investigate the multiple modalities where fiscal and monetary governance transpires and their distinct logics and power systems that lead to the actualisation of a common fiscal-monetary space.

How EMU subjects strive to adhere to specific programmes, designed in the name of normalcy, is shaped by the very power relations in which they are embedded. As Campbell notes, "disciplinary power affects a problematization through strategies of normalization" which "work on people and places so as to compare, differentiate, hierarchize, and homogenize them in ways that map them as manageable problems amenable to solutions." ${ }^{19}$ Technologies of risk management normalise economic conduct by reproducing past propensities in the design of future strategies, thereby endowing these techniques with a temporal "stability" and "objectivity" which they would otherwise not possess. Experts enter to formalise, and subsequently depoliticise, what is arguably the (re)application of a specific set of problematisations and programmes. In the process, the scope of available alternatives is minimised as risk management becomes entrenched as a regular practice for representing normalcy and monitoring deviance in EMU.

Given the "inherent controversy and undecidability of truth claims," calculative technologies have "come to replace the trust that formulae of government once accorded to

\footnotetext{
${ }^{19}$ David Campbell, National Deconstruction: Violence, Identity and Justice in Bosnia (Minneapolis: University of Minnesota Press, 1998), xi.
} 
professional credentials. ${ }^{, 20}$ Particular notions of normalcy are cemented around a numerical output, to which government behaviour is compared. Ostensibly, this works to shield this technical knowledge from contestation by removing it from political debate. While helping to define normative boundaries by mediating the knowledge of liabilities, risk perception and risk communication are bridged; together becoming regularised through the calculation's institutionalisation. ${ }^{21}$ These kinds of technologies discipline performance by ensuring that reputations are protected from discretionary misconduct. Such a mentality is noticeable in the push to increase the surveillance authority and reach of the European Court of Auditor (ECA) and EUROSTAT, allowing for the direct assessment of the quality of financial operations of individual Member States. But as I demonstrate, new mechanisms have been instituted that question predetermined reference values and the reinforcing doctrine that quantitative measures are necessary for the constitution of a healthy fiscal-monetary space. Discretion is increasingly at the core of the new technologies of government and this impacts how power is exercised in the formation of EMU subjectivities.

Power is a constitutive force that is inextricably connected to the process of subjectification; the terrain where identities and interests are constructed. Technologies, and the rationalities they embody, shape conduct and subjectivities according to defined strategies. Uncertainty fosters new, non-quantitative mechanisms for modulating fiscal behaviour that were not visible with the original Pact. Through these techniques of government, specific sites of articulation emerge where authority is exercised in the

\footnotetext{
${ }^{20}$ Nikolas Rose, "Governing 'Advanced' Liberal Democracies," in Foucault and Political Reason: Liberalism, Neo-liberalism and Rationalities of Government, ed. Andrew Barry, Thomas Osborne, and Nikolas Rose (Chicago: The University of Chicago Press, 1996), 55.

${ }^{21}$ Jens O. Zinn and Peter Taylor-Gooby, "Risk as an Interdisciplinary Research Area," in Risk in Social Science, ed. Peter Taylor-Gooby and Jens Zinn (New York: Oxford University Press, 2006), 32.
} 
reduction of contingency and the production of EMU subjects. From this perspective, the SGP may be considered the recomposition of discursively constituted "political processes of inclusion and exclusion" where certain analytical categories, and subsequently stabilisations, are privileged over others. ${ }^{22}$ Governmentality directs our attention to these procedures, thus shedding light on how subjects are constituted through the governmental mode of uncertainty. Our understanding of agency and interest formation is enhanced as we move beyond of the limits of conventional IR accounts to the very sites where identity and interests are articulated.

This historicised investigation does more that simply catalogue existing power systems. It also alerts us to how EMU incorporates these discursive practices in its construction of new geographies of power and responsibility. Here various forms of power may be deciphered relevant for conceptualising the SGP as a territory of government that competing IR theories fail to capture. Understood in relational terms, these systems of power often overlap thereby precluding a strict binary opposition in their delineation. In addition to "governmentality," post-disciplinary logics of "control" (Deleuze) are most evident in the dissection of the SGP. Member States are envisioned as "misfits" who are at risk of sabotaging the fiscal framework. Their profligate propensities must be curbed at all sites of potential deviation. Here authority "is based upon a dream of the technocratic control of the accidental by continuous monitoring and management of risk.",23

Acknowledging that failure is possible across multiple sites of this EMU assemblage, the "modulation" of conduct programmed into daily practice may reveal how governance is transforming with the shift to modes of risk and uncertainty. Whereas

\footnotetext{
${ }^{22}$ Marieke de Goede, "Discourse, Materiality and Economy," in International Political Economy and Poststructural Politics, ed. Marieke de Goede (New York: Palgrave Macmillan, 2006), 117.

${ }^{23}$ Nikolas Rose, Powers of Freedom (New York: Cambridge University Press, 1999), 235.
} 
discipline entailed both individualisation and normalisation, regimes of control are concerned with the "administrative management of populations at risk, anticipating 'possible loci of dangerous irruptions through the identification of sites statistically locatable in relation to norms and means." ${ }^{24}$ This propensity of Member States to violate the rules and norms of EMU is established through codes, accounts and feedback loops. Therefore, the objective is to regulate deviance rather than to reform the actor.

Governmentality helps us diagram these dispersed regulatory interventions that seek to modulate conduct as opposed to reforming it within confined institutions (i.e. asylum or factory). By interrogating the epistemological foundations of these surveillance mechanisms we are in a better position to understand how the (re)politicisation of fiscal relations is creating novel (contested) planes for the articulation of power and the fabrication of EMU subjectivities designed to mitigate uncertainty. Neither is this a primarily legalistic conception of power as a commodity nor is it ultimately reducible to sovereign forms. The idea of a government of economy introduces a self-regulating element to the organisation of EMU in the endeavour of promoting its optimal development. Although discipline and sovereignty remain of interest in helping understand how uncertainty is being managed through the calculative practices, my analysis will primarily concentrate on control and governmentality to reveal significant insights into EMU governance which much of the IR literature omits.

\section{Mentalities of Rule}

Finally, this deconstructive ethos tells us something about the programmatic character of EMU governance by problematising the political rationalities that make this space

\footnotetext{
${ }^{24}$ Robert Castel in Nikolas Rose, Powers of Freedom (New York: Cambridge University Press, 1999), 235.
} 
intelligible as a form of knowledge. Governmental rationalities are the ideational component that establishes a novel regulatory space by legitimating particular power systems that circulate to produce objects of rule according to defined criteria. ${ }^{25}$ Mainstream attempts to divorce this technoscientific epistemology from its socio-political context are what this dissertation challenges. I am not so concerned about the options for action that the knowledge of uncertainty presents in a given circumstance; which tends to preoccupy the liberal intergovernmentalist and CPE camps. Atomistic conceptions that reduce relations to an abstract set of cost-benefit analyses often ignore the political and social construction of the reality in which, and through which, these decisions are made. Instead, efforts are devoted to producing a policy output without serious regard for how that knowledge is constituted.

Whether or not Europe is substantively a more "uncertain world" after 2003, an analytics of government reveals how uncertainty is being reconfigured as an appropriate programme for governing fiscal relations given the trinity of inconsistencies identified above. Embedded in these practices is a history of governmental reason that is contingent on time and place rather than a priori and self-evident. Increasingly, these mentalities rely on creative entrepreneurialism as a model of good fiscal government. A critical genealogy enables us to diagnose how it is that we come to think of EMU in terms of uncertainty and subsequently act upon it through strategies designed to promote fiscal austerity.

Each authoritative regime exhibits its own unique political mentalities and the SGP is no different. These may be deciphered and distinguished:

in terms of the relatively systematic discursive matrices within which the

\footnotetext{
${ }^{25}$ Colin Gordon, "Governmental Rationality: An Introduction," in The Foucault Effect: Studies in Governmentality, ed. Graham Burchell, Colin Gordon, and Peter Miller (Chicago: Chicago University Press, 1991), 1 .
} 
activity of government is articulated, the particular languages within which its objects and objectives are construed, the grammar of analyses and prescriptions, the vocabularies of programmes, the terms in which the legitimacy of government is established. ${ }^{26}$

Rationalities translate reality into the domain of thought. As such, they equip us with the necessary intellectual apparatus to organise the fiscal-monetary space in alignment with the specific objectives and interests of EU policy-makers. Programmes are devised that articulate these ideas and visions of what proper fiscal conduct entails. An analytics of governments draws our attention to the very rationalisations underpinning and connecting these administrative efforts to address the problem of budgetary profligacy. It shows how uncertainty is appropriated to manage fiscal relations in specific ways, which endows EMU with a particular density and materiality and distinguishes it from previous regulatory capacities designed to modulate budgetary conduct.

\subsection{Reconstructing the Fiscal-Monetary Space}

The second thematic is symbiotically related to that of deconstruction. Excavating the governmental terrain of the SGP reveals how knowledge - as a susceptibility to vulnerable fiscal conduct and as a register of responsibility - is appropriated in the restitution of EMU following the Ecofin crisis. What kind of gravitational pull does the revised SGP exert on a fragmented collection of Member States, which may compel them to align their fiscal positions in accordance with the Pact's rules? Insofar as these stabilisations are being produced and renegotiated, what forms of power render them visible and real? Critical genealogies expose these problematisations as historical artefacts and the conditions facilitating their constitution. They allow us reconstruct the origins of governmental configurations and the practices that help establish and promote them.

\footnotetext{
${ }^{26}$ Peter Miller and Nikolas Rose, "Governing Economic Life," 6.
} 
In this way, an analytics of government serves a "reconstructive" function that is concerned with examining how this regulatory space is being reassembled through specific discursive practices of truth production. It emphasises the "performative" dimension of government by revealing EMU to be a "constantly mutating formation" of "contingent social arrangements" rather than the "manifestation of "deeper' processes" of the kind professed by historical materialists. ${ }^{27}$ While we analytically dissect the SGP for its technologies of subjectification, we simultaneously focus on the constitution of new subjects of government. Herein lies one value-added of this approach. It serves to deconstruct governmental regimes, as well as reconstruct the problematisations to which they are presented as solutions. Through this diagnosis of its discursive and epistemological regularities, the problem space of EMU becomes known. Such knowledge can then be incorporated into political action - though policy output is not the immediate intention.

\section{Performativity}

Uncertainty acts as a "boundary object" that moderates these configurations. To shape the emergence of these assemblages is to exert a certain power, or leverage, over them. Not "an economistic conception of power, whereby power is regarded as a commodity to be wielded by agents" 28 but "as something which circulates, or rather as something which only functions in the form of a chain...never localised here or there...but employed and exercised through a net-like organisation." 29 As an analytic device, governmentality focuses our attention on how these partial stabilisations are produced and the conditions necessary for

\footnotetext{
${ }^{27}$ Andrew Barry and Don Slater, "Introduction," in The Technology Economy, ed. Andrew Barry and Don Slater (New York: Routledge, 2005), 14-15.

${ }^{28}$ David Campbell, "Political Prosaics, Transversal Politics," in Challenging Boundaries, ed. Michael J. Shapiro and Hayward R. Alker ((Minneapolis: University of Minnesota Press, 1996), 18.

${ }^{29}$ Michel Foucault, “Two Lectures," in Power/Knowledge : Selected Interviews and Other Writings, 98.
} 
their actualisation. We come to know EMU in part through these temporal configurations and their respective modes of governance. There is no innate material property to EMU, such as the capitalocentric CPE would lead us to believe. Rather these are constellations of contestable social relations that together configure this fiscal-monetary space called EMU.

If the theoretisation of uncertainty is distinctly marginal in mainstream IR, then any notion of its conditional nature as a boundary object is virtually non-existent. To properly understand how this modality of governance is deployed in the context of the SGP crisis requires an examination of how it is problematised and translated into material reality. Depending on how numbers are operationalised and for what purpose, uncertainty is simply one method for problematising an indeterminate future. Its performative properties derive from its incorporation into the political and economic infrastructure as it helps frame the terms of debate and makes EMU's future intelligible according to a specific mentality. Donald MacKenzie refers to this as the "performativity of markets.",30

Inspired by Michel Callon, "economics, in the broadest sense of the term, performs, shapes and formats the economy, rather than observing how it functions." ${ }^{31}$ It asks how agencies are constituted rather than assuming a rational homo economicus, how interests are constructed rather than understanding them as a priori, and how socio-technical practices are organised rather than what reality they represent. To reduce social complexities to static calculations - as is typical of liberal IG - is to neglect what Callon labels as "framing" and "disentangling.,"32 Markets are continually negotiated. Without the potential to "exclude things" and "leave certain costs or claims out of the calculations, and

\footnotetext{
${ }^{30}$ Donald MacKenzie, An Engine, Not a Camera (Cambridge, MT: The MIT Press, 2006), 16.

${ }^{31}$ Michel Callon, "Introduction: The Embeddedness of Economic Markets in Economics," in The Laws of Markets, ed. Michel Callon (Oxford: Blackwell Publishing, 1998), 2.

${ }^{32}$ Ibid, 36-37.
} 
deny responsibility for certain consequences," markets would not work. ${ }^{33}$ Uncertainty is itself a method of framing that discriminates amongst various factor inputs in the production of markets. Together with risk, it acts as a boundary object and functions to unite dispersed sites across the spatial-temporal terrain of EMU.

Various forms of expertise mediate this representational process. Quite often, however, these assume their authority by aligning social forces in congruence with what is purported to be an uncontested empirical reality. Demand equals supply, strong and stable exchange-rates, low inflation are examples of statements that have been presented as key referents to universal economic laws. This penetration of the neoliberal orthodoxy into the Continent has been codified in significant ways. The Single European Act (SEA) of 1986, which established the formal parameters of the "Single Market 1992" project, entrenched this ideational infrastructure which was then incorporated into the Maastricht Treaty (1992). Subsequently, its anti-inflationary objectives formed the bedrock of the Economic and Monetary Union itself.

What appeared to prove effective in the economic sphere was then eagerly exported to other disciplines, including international relations. Progressively we witnessed that displacement of discretionary calculative practices in favour of a defendable process. ${ }^{34}$ Functionalist explanations gained in popularity and legitimacy as their capacity to mitigate an ever burgeoning realm of risks increased. These abstract "systems forced people to focus instrumentally on the specific knowledge of risk" with little regard for the discursive dimension involved in its management. ${ }^{35}$ Giddens even heralded the "evaporation of

\footnotetext{
${ }^{33}$ Timothy Mitchell, "The Properties of Markets," 244.

${ }^{34}$ Michael Power, The Risk Management of Everything (London: Demos, 2004), 11.

${ }^{35}$ Richard V. Ericson and Aaron Doyle, "Risk and Morality," in Risk and Morality, ed. Richard V. Ericson and Aaron Doyle (Toronto: U of T Press, 2003), 3.
} 
morality" as "moral principles run counter to the concept of risk and to the mobilising dynamics of control. Morality is extrinsic so far as the colonising of the future is concerned." 36

Essentially yielding little in terms of indisputable conclusions, this ontopolitical drive to establish innate causal categories that transcend "politics" itself is quite dubious. ${ }^{37}$ False dichotomies are often the result. David Campbell is correct in his critique of IR theorists who develop "research agendas" similar to their counterparts in the physical sciences. Even constructivists, such as Wendt, who proclaim to surpass the "rationalist problematique" nevertheless "exhibit an overwhelming but underrecognized commitment to many of the general tenets of that disposition." knowledge," risk is said to accurately designate a condition of abnormality. Regarded as a tangible force or event, it may thus be mitigated through appropriate programmes of risk management. This "desire to replicate the prescriptive and predictive success of the hard sciences and a belief in the infallibility of rationalist-empirical epistemology" is reflected in the research agendas of IG and many operating under the historical materialist banner. ${ }^{39}$ Vast arrays of calculations are performed in order to identify the variance around an expected value. Once codified as a calculable entity or the standardisation of normalcy, risk is said to inform decision making with a high degree of accuracy "whose strength consists in its machine-like, engineering quality., 40

\footnotetext{
${ }^{36}$ Anthony Giddens, Modernity and Self-Identity: Self and Society in the Late Modern Age (Stanford: Stanford University Press, 1991), 151.

${ }^{37}$ Nikolas Rose and Peter Miller, Governing the Present: Administrating Economic, Social and Personal Life (Malden, MA: Polity Press, 2008), 6.

${ }^{38}$ David Campbell, "Political Prosaics, Transversal Politics," 12.

${ }^{39}$ Darryl S.L. Jarvis and Martin Griffiths, "Learning to Fly: The Evolution of Political Risk Analysis," Global Society 21, no. 1 (2007): 17.

${ }^{40}$ Bridget Hutter and Michael Power, Organizational Encounters with Risk (Cambridge: CUP, 2005), 7.
} 
Unfortunately, ambitions to unravel the fluidity of social phenomena through technical means, such as risk calculus, and freeze it in hermetic compartments have proven a failure. One simply has to observe the success, or lack thereof, of most of the world's leading economists in accurately predicting the recent credit crisis and its severity. Their dismal track record, however, is seldom seriously questioned. With so much at stake, in terms of policy direction and wealth decimation, one has to ask why such poor performance is rarely held to account. To assume that technical expertise is completely removed from social relations misunderstands that technical objects are themselves socially constructed. In turn, they influence how the socio-economic is represented as a thinkable and calculable reality and thus an object of government susceptible to technical expertise. Much to their detriment, however, conventional IR accounts fail to address this regulatory dimension of the SGP.

Conversely, an analytics of government compels us to rethink the artificial autonomy granted to EMU subjects who are positioned in relation to exogenous social contexts. Rather than in terms of innate properties, we come to understand EMU as "the heterogeneous engineering of assemblages ('markets') that enlist specific social capacities. ${ }^{, 41}$ The relationships that produce these subjectivities are the context of the politics of representation. Although the politicisation of markets may not be novel, the infusion of politics into the operative framework of EMU - bolstered by the Lisbon agenda and demonstrated by the Ecofin crisis - is taking new forms. Increasingly, these "hot" situations are pre-empting the contestation of previously immune calculative technologies

\footnotetext{
${ }^{41}$ Andrew Barry and Don Slater, "Introduction," in The Technology Economy, 9.
} 
and opening up new spaces for rethinking how they are deployed within EMU. ${ }^{42}$

Governmentality equips us with the necessary tools to analyse these transformations, which traditional accounts lack.

Nevertheless, we should be wary of attributing excessive, theoretical density to this approach. A:

critical ontology of ourselves has to be considered not, certainly, as a theory, a doctrine, nor even as a permanent body of knowledge that is accumulating; it has to be conceived as an attitude, an ethos, a philosophical life in which the critique of what we are is one and the same time the historical analysis of the limits that are imposed on us and an experiment with the possibility of going beyond them. ${ }^{43}$

Uncertainty is now testing the very limits of this imaginative capacity in the sphere of European fiscal governance. We are motivated to consider the variegated conditions and circumstances that contribute to the development of this fiscal-monetary space, which is essential as Europe is a mutating entity. It has not reached a zenith whereby everything is uniform and stable nor will it. Quite the contrary, EMU is arguably unstable in that its boundaries are simultaneously expanding and disaggregating as it includes new Member States and its territory of government adjusts to account for changing articulations of how to order these manufactured spaces. As Walters and Haahr contend, "there is no generic European government or European integration" but "only particular regimes of thought and practice within which certain ways of governing Europe become possible.",44

Undoubtedly, to understand this transition one may be burdened with the arduous, if not impossible, task of unearthing ontological categories and explaining their "causality."

\footnotetext{
${ }^{42}$ Michel Callon, "An Essay on Framing and Overflowing: Economic Externalities Revisited by Sociology," in The Laws of Markets, ed. Michel Callon (Oxford: Blackwell Publishing, 1998).

${ }^{43}$ Michel Foucault, "What is Enlightenment," in The Foucault Reader, ed. Paul Rainbow (New York: Pantheon, 1984), 50.

${ }^{44}$ William Walters and Jens Henrik Haahr, Governing Europe: Discourse, Governmentality and European Integration (New York: Routledge, 2005), 14.
} 
This is what much of the IR literature sets out to do. But that implies attempting to digest deep social transformations and is best left to political philosophers rather than political economists. My intentions are more modest. I am interested in revealing how the revised Pact signals an alternative approach to framing the problem of governing fiscal relation in EMU by acting on the capacity of governments as discretionary actors; namely governing through uncertainty. Targeting their liberty, the architects of EMU can help induce the internalisation of self-regulation thereby fostering greater compliance with the statutes of the framework. However, greater manoeuvrability in the construction of new planes of government entails renewed contestation regarding how calculations are rationalised and deployed. A genealogical approach allows us to delineate the relationships that coalesce when the technological apparatus of EMU is mobilised in the realisation of a coherent fiscal-monetary space.

\section{Critical Ontology of Normalcy}

Through a critical ontology, we can come to terms with the embeddedness of economic action in Europe. Situated in new fields of uncertainty - where the revival of growth and employment as principal objectives of the SGP is characterised by a transformation in how fiscal relations are problematised - is an emerging regime of truth for rendering calculation possible. Uncertainty accelerates and modifies our conception of what is accepted as being true by constructing new notions of normalcy. This is another reconstructive feature which I take into account. Normative claims designating "good performance" are at the core of rebuilding this regulatory regime. Yet given the disparities that exist in constructing this spatial-temporal order and making it intelligible, it is foolish to speak of one coherent "normal" state and its representation. However, the pre-packaged commercial objectives 
found in liberal IG or the economic determinism of CPE are indicative of such an attempt. Their notions allude to a priori totalities that are exogenous of social relations. But "practices of government cannot be understood as expressions of a particular principle, as reducible to a particular set of relations, or as referring to a single set of problems or functions." ${ }^{45}$ Such assertions are tremendously problematic.

By reducing the management of uncertainty, or risk, to a set of mathematical computations designed to verify some supposed "normal" empirical reality outside of society, conventional IR approaches are blind to the notion that normalcy entails more than just simple verification. It embodies values about how things ought to be and conditions subject formation along these vectors. Encompassing a "fact/value ambiguity that has always been present in the idea of the normal," EMU becomes a terrain where competing visions of normality are articulated. ${ }^{46}$ Contestation abounds as different parties revert to opposing normative positions about the nature and trajectory of EMU governance in order to legitimise their respective claims. Once/if consensus is achieved, this representation of normalcy is institutionalised and reproduced through the technological infrastructure to control the conduct of Member States. Leverage is exerted in the process whereby EMU subjects subscribe to the shared normative discourse and adopt its policies of Community compliance.

My analytics of government helps us dispute the facticity of the subject/object dichotomy by unpacking the discourse of normality presupposing this convergence. Such an approach challenges the "simplistic duality" underpinning IG that views EU

\footnotetext{
${ }^{45}$ Mitchell Dean, Governmentality: Power and Rule in Modern Society (New York: Sage, 1999), 29.

${ }^{46}$ Ian Hacking, The Taming of Chance (New York: Cambridge University Press, 1990), 168.
} 
organisations as embedded within, yet ontologically separate from, their environments. ${ }^{47}$ In its place, we come to recognise the constitutive, albeit contradictory, relationship between the programmatic and operational components of politico-economic activity. However, new analytical tools are necessary in order to properly appreciate this dialectic between expertise and politics. Aggregating risk techniques are proving inadequate to control for the contingency implicit in the often random and unanticipated nature of EMU politics. A preferred approach to governing these indeterminate futures is revealing itself. Imagining them as singular or unique, however, demands a re-examination of the template which underpins how "normal" practice is constituted and how the notion of surveillance as regulation embedded within the political economy of EMU has changed since 2005.

\section{Spatial-Temporal Coordinates}

Suspending these quests for ontological foundations also allows us to ask a different set of questions about the sedimentation of normalcy in the reconstruction of a novel spatialtemporal order in Europe. Rather than deciphering governance from a Cartesian interpretation of space while searching for the appropriate level of analysis to explain it, we can interrogate how specific discursive practices shape how space and time, as governmental constructs, are organised to render EMU thinkable as an object of intervention. So intensive is this discursive constitution of spatial coordinates, it prompts Walters to contend that "in Europe that experimentation and readjustment in the relationship between governance, political space and bordering has arguably gone furthest." ${ }^{48}$ With this mind, in the remainder of this section, I turn to an interrogation of

\footnotetext{
${ }^{47}$ Bridget Hutter and Michael Power, Organizational Encounters with Risk, 3.

${ }^{48}$ William Walters, "Rethinking Borders beyond the State," Comparative European Politics 4 (2006): 142.
} 
what governmentality can reveal about the spatial-temporal constitution of the EMU that helps redress the deficiencies found in the traditional IR literature.

To challenge defined boundaries in order to grasp their politicisation and the constitution of subjects and objects of governance involves an investigation of all their limits at the sites of their articulation. EMU is a novel space that is historically contingent on the discursive practices that give it substance and meaning. This spatial-temporal dimension is markedly absent from mainstream expositions of the SGP problematic. Instead we are presented with a linear history plotted on a Cartesian graph. Usually closed territories, these conceptualisations fail to explain how the EMU space is porous and open; a production in the exercise of power. But "space and time cannot be treated as uniform background noise, as abstract ontological conditions to be acknowledged and then discarded. ${ }^{, 49}$ A proper understanding of the problematic must acknowledge the multiple sites where power is exercised in the production of meaning and knowledge of EMU.

As I mentioned above, the SGP represents a fiscal-monetary space symbol designed as a tool for managing the challenges posed by budgetary indiscipline. Its authority is inexorably connected to the parameters that define EMU. Otherwise, it would be redundant if it was divorced from the very rationality of an economic and monetary union. Hence, a relationship exists between the spatial properties of EMU and its governmental logics. Symbols - being a form of discursive practice - link material spaces, by organising them, with corresponding mentalities of rule; in this case uncertainty. A critical genealogy traces the lineage between various levels of analysis in order to make this link explicit rather than taking it for granted as conventional IR theories tend to do.

\footnotetext{
${ }^{49}$ Robert B.J. Walker, Inside/Outside: International Relations as Political Theory (Cambridge: Cambridge University Press, 1993), 130-131.
} 
Concepts and governmental regimes develop in a contested political space rather a pre-existing evolutionary state of nature. As Colin Wight notes, "concepts of time and space represent the ontological possibility of the 'political' as opposed to neutral methodological ways of framing political space., ${ }^{50}$ To avoid the conceptual dilemma of arguing the reductionist case that rationalities and spatial constructs are simply the sum of their parts, a genealogical approach is employed. By dissecting the material practices which compose this fiscal-monetary space, it is possible to understand how various temporalities and spatialities are inscribed into EMU subjectivity by mechanisms such as the SGP.

This spatialisation of governmental thought deconstructs the European economy to show that it is more than just the aggregation of national territorial boundaries or a neutral backdrop as IG would contend. Moreover, it demonstrates that the connection between empirical reality and political rationality does not rest on "an a priori logical necessity." has to be empirically proven. For this purpose, a genealogy adequately diagrams how EMU is constructed as a calculable space with a unique temporality. Techniques of uncertainty travel across this temporal plane disturbing previous modes of risk while rendering new sites real and amenable to intervention.

Uncertainty is pivotal in the renegotiation of the terrain where politics and expertise interact to reconfigure a new regulatory capacity for mitigating negative externalities produced by the trinity of inconsistencies. In this sense, territoriality does not refer to a bound geopolitical region acting as a container for the emergence of contested practices involved in the articulation of EMU. Of course, I am not decoupling governmentality from sovereign states. Sovereign power remains a significant force in

\footnotetext{
${ }^{50}$ Colin Wight, Agents, Structures and International Relations (New York: Cambridge University Press, 2006), 108.

${ }^{51}$ Ibid, 108.
} 
the construction of identities and interests. Rather, my contention is that in the effort to monitor and manage contingency, new planes are being erected that help facilitate this activity, which "transverse" and even distort the demarcated lines of modern states. ${ }^{52}$ Governmentality allows us to incorporate valuable mainstream insights into sovereignty while moving beyond their remaining restrictive deficits.

ECB monetary policy is a catalyst for many of these patterns of integration as it generates convergence pressures across the eurozone, especially in money and bond markets. Technical and epistemic in character, it conditions how relations are organised across national borders. Nevertheless, as Macartney and Moran demonstrate, these are matters of degree since there does not exist a single template for EMU governance. Together with budgetary policy, banking and financial market regulation (e.g. TARGET2, Single Euro Payment Area (SEPA)) still fall within the auspices of Member States. $^{53}$

Campbell argues that the "sovereignty-problematic" induces an "anxiety" among IR scholars whose "desire for presence and...fear of absence" compels them to reify the unitary state as the fundamental bedrock of politics. ${ }^{54}$ In the process, they transform "dynamic, interconnected phenomena into static, disconnected things," which precludes mainstream theories from enhancing their interpretative capacities and recognising that borders are themselves fluid sites of contestation. ${ }^{55}$ An analytics of government is sensitive to this performative quality revealing how fiscal surveillance constructs the very

\footnotetext{
${ }^{52}$ David Campbell, "Political Prosaics, Transversal Politics," 20.

${ }^{53}$ Huw Macartney and Michael Moran, "Banking and Financial Market Regulation and Supervision," in The Euro at 10: Europeanization, Power, and Convergence, ed. Kenneth Dyson (New York: Oxford University Press, 2008), 325-40.

${ }^{54}$ David Campbell, "Political Prosaics, Transversal Politics," 20.

${ }^{55}$ Eric R. Wolf, Europe and the People without History (Berkeley: University of California Press, 1982), 2.
} 
domains where it functions. Acknowledging how these dimensions are spatially and temporally sensitive, we are in a better position to rethink how uncertainty is producing a novel regulatory framework in Europe, the power relations immanent in these matrixes of government, and how they leverage the formation of new subjectivities that may induce the internalisation of self-regulation. All of this rests on the way that readings of uncertainty help define adoptable notions of normal fiscal conduct.

\subsection{Risk and Uncertainty as Modes of Governance}

Facing an economic correction, the allure of spending beyond their means to satisfy domestic needs and interests may have had a seductive effect on Member States as it does in the throngs of the current credit crisis. Arguably, however, the consequences of such behaviour were not adequately understood or else substantial measures would have been taken to prevent the 2003 Ecofin crisis. ${ }^{56}$ Furthermore, even the arsenal of mathematical models and formulas aimed at mitigating dangers to EMU proved futile in forecasting this fiscal misconduct or the subsequent decision to suspend the excessive deficit procedure against France and Germany. Risk management systems geared to monetising time and space by "rendering these co-ordinates 'quantitative' and thereby 'calculable"” were confronted with the contradictory relationship between the programmatic and operational components of European political economy. ${ }^{57}$ Much to the chagrin of the ECB and EFC specialists, amongst others, politics defied expertise as the "Franco-German motor" demolished the very rules it designed. Political power was flexing its muscles and a novel regulatory system was popping up.

\footnotetext{
${ }^{56}$ In today's economic correction, European governments favour regulatory measures to rather than abundant fiscal stimulus injections in fear of sparking inflationary pressures.

${ }^{57}$ Michael Pryke and John Allen, "Monetized Time-Space: Derivative-Money's 'New Imaginary," Economy and Society 29, no. 2 (May 2000): 270.
} 
My intention is to document how this emerging phenomenon, known as EMU, is coming into being through an alternative approach to fiscal management embodied in the 2005 SGP reforms. As a mode of regulation, uncertainty helps define EMU governance by producing and validating knowledge in terms of a vulnerability to profligate fiscal conduct and thereby as a register of responsibility bound to variegated notions of normalcy. Legitimised by the Lisbon agenda, new forms of control and subjectification are produced, which are helping dissolve barriers surrounding previously immune forms of expertise grounded in risk. It frames how EU policy-makers come to understand the SGP problematic through calculative estimations that are primarily derived from nonquantitative/non-probabilistic methods. In contrast to conventional risk management, uncertainty-based forms of rule are not grounded in the principle of "instrumental rationality" where the objective is "to identify the means by which to obtain certain previously established ends. ${ }^{58}$ Rather than verifying some empirical reality, new EMU actualities are being constructed through the modality of uncertainty, in the process transforming the means into ends themselves and intensifying tensions as the technocratic is reabsorbed into the political. We come to know EMU in part through its modes of governance.

Risk also exhibits a performative capacity to shape the material world which it seeks to describe. In this sense, modes of governance display a programmatic character that aligns a political rationality with its respective technologies of government. Not only do they infuse significant ideational changes into our understanding of EMU but risk and uncertainty reconfigure the actual organisational infrastructure and practices that render this

\footnotetext{
${ }^{58}$ Joost Van Loon, Risk and Technological Culture: Towards a Sociology of Virulence, (New York: Routledge: 2002), 189.
} 
fiscal-monetary space real. However, to speak of them in either analytically real or unreal terms is misleading because it assigns an ontological value that, as governmental constructs, they do not possess. A better approach is to recognise how their changing relationship is helping engineer the emergence of this novel plane through different mechanisms of surveillance and what this transition means for European political economy.

For this purpose, an analytics of government reveals how risk and uncertainty are particular ways of interpreting and managing fiscal relations. First, the analytical and conditional dimensions of each one will be introduced. This entails distinguishing between risk and uncertainty by explaining their intellectual heritage and their respective conceptual architecture. Properly understanding how they differ is essential given the general tendency to misrepresent uncertainty as a risk. Irrespective of their common impression, they influence governance in diverse ways.

Uncertainty does not simply displace risk as their relationship is not one of rigid binary opposition. Rather a preferred understanding "regards them as related along multiple axes, with the effect that no single continuum (such as one running from statistical probability to vague hunches) will adequately represent their relationship." Consecutively, to illustrate their conceptual status, I turn to a discussion of the operational elements that allow risk and uncertainty to delineate the parameters and objects of this emerging fiscal-monetary space. Here the migration of risk management from the corporate sector is traced. Familiar with their respective ideational and practical boundaries, we can differentiate how risk and uncertainty are translated into modes of regulation that coalesce to manufacture EMU.

\footnotetext{
${ }^{59}$ Pat O'Malley, Risk, Uncertainty and Government (Portland: The Glasshouse Press, 2004), 21.
} 


\section{Risk: The Analytical and Conditional}

As a material artefact, EMU incorporates risk modeling in its construction of new geographies of power. Its calculative practices articulate governmental programmes and shape the economic and social relations that comprise this emerging regulatory space. EMU subjectivities emerge within these discourses of mobilised expertise. How risk is translated into a regulatory capacity charged with mitigating dangers alerts us to the contingency of the entire EMU enterprise. But it does so in a specific fashion that has popularised and intensified a highly quantitative approach to governance.

A governmental construct, risk frames problems in terms of an aggregable and probabilistically quantifiable frequency of an undesirable activity. Probabilistic outcomes may be tamed by quantifying and pooling them, ensuring an enhanced degree of control. Analytically, I am arguing the case that risk is one of the central organising principles that helps define the parameters of EMU as a recognisable and governable space. Through the accumulation of knowledge, risk strategies instill stability by ordering EMU reality according to a discernable managerial approach based on the regulation, if not elimination, of potentially threatening variables, such as fiscally profligate behaviour. Arguably, this organisational model seems attractive when configuring a fiscal-monetary space as complex as EMU.

Georg Simmel, the German sociologist, observed this fixation with probabilistic estimations at the beginning of the twentieth century. Noting how pronounced this calculative mentality of control began to be in the modern economy, he asserted that:

the calculating exactness of practical life which has resulted from a money economy corresponds to the ideal of natural science, namely that of transforming the world into an arithmetical problem and of fixing every one of its parts in a mathematical formula. It has been money economy which has this 
filled the daily life of so many people with weighing, calculating, enumerating, and the reduction of qualitative values to quantitative terms. ${ }^{60}$

Removed from fickle human discretion, economic performance may be protected and with it the stability objectives of the entire monetary union. The last thing that markets desire is ambiguity. Hence, risk maintains the functional need to preserve myths of control by granting authority to mathematical and technical modeling as opposed to moral and individualised approaches. SGP "reference values" exemplify this strategy of risk management as they locate and define risk at particular instances of fiscal behaviour (3 percent of GDP deficit ratio and 60 percent of GDP debt ratio). Although critiqued as imposing an artificial uniformity on EMU, they are significant in the "development of a causal knowledge of deviance and normalization."61 Normative claims are based upon this knowledge, which informs governmental rationalities and the subsequent institutionalisation of risk technologies.

In his analysis of the episteme of modern thought, Foucault observed a rupture of thinking in terms of "classification" towards one of "causation." 62 Especially pronounced in the economics discipline, the discursive and technological risk apparatus is donated to pre-empting the cause and effect relationship. Statistically refined by economists, "risk is the measure of variance around an expected value" and is considered a tangible phenomenon/force by most of the literature. ${ }^{63}$ General equilibrium theory, which often informs IG studies of EMU, is indicative of this tendency to smuggle in abstract game-

\footnotetext{
${ }^{60}$ Georg Simmel, "The Metropolis and Mental Life," trans. Edward A. Shils. in Second-Year Course in the Study of Contemporary Society, ed. Harry D. Gideonse et al. (Chicago: Chicago University Press, 1936), 196.

${ }^{61}$ Pat O'Malley, "Risk and Responsibility," in Foucault and Political Reason: Liberalism, Neo-liberalism and Rationalities of Government, ed. Andrew Barry, Thomas Osborne, and Nikolas Rose (Chicago: The University of Chicago Press, 1996), 189.

${ }^{62}$ Michel Foucault, The Order of Things: An Archaeology of the Human Science (New York: Vintage, 1970).

${ }^{63}$ Dimitris N. Chorafas, Risk Management Technology in Financial Services (New York: Elsevier, 2007$), 24$.
} 
theoretic modelling with the intention to identify this degree of probability. ${ }^{64}$ Once it is determined, this risk variable is then transformed, as "objective knowledge," into a capacity to mitigate dangers. Presented as scientific fact, risk is said to provide an accurate range of referentiality according to which fiscal conduct may be empirically measured and responsibility assigned. On the basis of this, optimal strategies of action are then designed.

Power as calculation is revealed and institutionalised through these processes of risk identification and prioritisation that are implicit in the preventative arm of the Pact. These routine micro-practices monitor a vast array of components contributing to the national fiscal position in the effort to determine budgetary liability. Judged against preestablished reference values (deficit and debt ratios), power is exercised through constant surveillance. It targets those who deviate from the statistical norm by connecting decisionmaking with risk management. Attention is drawn to how technologies of risk engender the "calculated manipulation" of the actor in accordance with the aforementioned averages.

Whether disciplinary power with its current punitive measures (i.e. fines) is sufficient is very much in doubt. Without credible threats it has proved ineffective in producing obedience. David Lyon wrestles with this "conundrum," observing that:

the more stringent and rigorous the panoptic regime, the more it generates active resistance, whereas the more soft and subtle the panoptic strategies, the more it produces the desired docile bodies. ${ }^{65}$

Certainly, calculative forms of power associated with risk management exhibit some of this subtlety as they lack the more "juridical-political" character of sovereign power. Here

\footnotetext{
${ }^{64}$ Guido Tabellini, "Money, Debt and Deficits in a Dynamic Game," Journal of Economic Dynamics and Control 10 (1986): 227-42; Robert Putnam, "Diplomacy and Domestic Politics: The Logic of Two-level Games," International Organization 42, no. 3 (1988): 427-60; Andrew Moravcsik, The Choice for Europe: Social Purpose and State Power from Messina to Maastricht (Ithaca: Cornell University Press, 1998). ${ }^{65}$ David Lyon, "The Search for Surveillance Theories," in Theorizing Surveillance, ed. David Lyon (Portland: William Publishing, 2006), 4.
} 
"power comes from below, that it, there is no binary and all-encompassing opposition between rulers and ruled at the root of power relations." ${ }^{96}$ Conduct is supposedly shaped by regulatory practices "premised on an epistemology that privileges 'facts' established through measurement" as opposed to "capricious" human behaviour. ${ }^{67}$

But this is not a benign occurrence in the slightest. Qualculation undermines accountability rooted in the democratic process (stakeholders) and public debate or markets (shareholders). ${ }^{68}$ According to Marieke de Goede, the "increasingly mathematical and depoliticised nature of risk models displaces responsibility for financial decisionmaking." 69 She draws on Niklas Luhmann who argues that understanding "misfortune in the form of risk...immunizes decision-making against failure" as it is justified by a battery of instrumentally rational and supposedly "objective" criteria. ${ }^{70}$ Attributing authority to something, however, without questioning the source of its legitimacy is a dangerous precedent to begin. This slippery slope can have severe repercussions as power becomes concentrated in the hands of an unelected elite. Although risk managers/experts still enjoy this buffered form of authority, the dominance of their monopoly has been disturbed with the movement to uncertainty-centred modes of governance.

At the same time, granting objectivity to "statistical correlations between series of phenomena" with the ambition of regularising social activity neglects three vital aspects of governing through risk. ${ }^{71}$ First, risks are "conditional" because they fulfill a specific

\footnotetext{
${ }^{66}$ Michel Foucault, The History of Sexuality, Vol. 1 (New York: Vintage, 1990), 94-95.

${ }^{67}$ Robert Deuchars, The International Political Economy of Risk: Rationalism, Calculation and Power (Burlington: Ashgate Publishing Company, 2004), 113.

68 These ubiquitous computing systems give the impression of transforming quantitative calculations into qualitative judgements.

${ }^{69}$ Marieke de Goede, "Repoliticizing Financial Risk," Economy and Society 33, no. 2 (November 2004 ): 213.

${ }^{70}$ Niklas Luhmann, Risk: A Sociological Theory (Berlin: de Gruyter, 1993), 13.

${ }^{71}$ Robert Castel, "From Dangerousness to Risk," in The Foucault Effect: Studies in Governmentality, ed. Graham Burchell, Colin Gordon, and Peter Miller (Chicago: Chicago University Press, 1991), 284.
} 
objective that is predefined. As such, they do not exist devoid of a particular context or problematic. Two, risks are "reactive" since future forecasts hinge on the circumstances which preceded them and their interpretation. For David Garland, "extrapolations from past experiences are always inferences from a limited data set using premises (about cause and effect, about factors involved, about ceteris paribus) that may be disproved by subsequent events. ${ }^{, 72}$ Lastly, the degree to which individuals and institutions expose themselves to potential hazards varies as risks are "interactive." ${ }^{, 73}$ How risk prone someone is depends on the perception of their capacity to tolerate the unwanted outcome. Knowledge of the environment and other agents factors into this decision. Adams refers to this as one's "risk thermostat." 74

Aside from economists, many "risk society" theorists also subscribes to this philosophy. ${ }^{75}$ Risk is perceived as the unavoidable symptom of globalisation that can be unearthed through probabilistic techniques. In fact, they also define uncertainty in these categorical terms as an incalculable risk. Uncertainty is a by-product of modernity which produces impending catastrophes that occur at frequencies too low to statistically predict. In short, this is indicative of the desire to "refurbish" social inquiry through the prescriptive positivism of the natural sciences and align it with the infallibility of a rationalist-empirical epistemology.

Yet, there is little empirical evidence to support Beck's thesis purporting that state failure is endemic with the advent of neoliberal inspired globalisation. Tax receipts and

\footnotetext{
72 David Garland, "The Rise of Risk," in Risk and Morality, ed. Richard V. Ericson and Aaron Doyle (Toronto: U of T Press, 2003), 53.

${ }^{73}$ Ibid, 55 .

${ }_{75}^{74}$ John Adams, Risk (London: UCL Press, 1995).

${ }^{75}$ Ulrich Beck, Anthony Giddens, and Scott Lash, Reflexive Modernization (Cambridge: Polity Press, 1994); Ulrich Beck, World Risk Society (London: Polity, 1999).
} 
government spending are not in decline but rather ballooning as the current SGP debacle demonstrates. More significantly, what Beck and other social pessimists of his persuasion neglect is the political factor and how it thwarts the functionality of maintaining control through risk. Beck is critiqued by thinkers, such as Bruno Latour, for divorcing technoscientific epistemology from its disorderly and uncertain socio-political context. ${ }^{76}$ Under these conditions, the selection of outcomes in accordance with the dictates of expected utility modelling is prevented. Should uncertainty only be a risk disguised by cognitive limitations, then:

how ideas inform agency in moments of uncertainty would be irrelevant... All ideas would be correspondence theories with zero ambiguity, and courses of action, interests, and choices, would be clear. In sum, politics would be unnecessary; which given its ubiquity suggests that there may be limits to viewing uncertainty as a problem of complexity. ${ }^{77}$

But interests are ideationally-bound rather than pre-given, immutable facts. They have a very striking political character to their composition.

Arguably, nowhere is this more apparent than with the Ecofin crisis itself. In its aftermath, one can appreciate how the task of identifying and defining threats to EMU demands an approach which is not ambivalent about political uncertainty. The conceptual, ideological and institutional inconsistencies in governing fiscal relations necessitate recognising the logic of contingency, its formulation in rendering realities manageable and its status as a model of good governance. The Ecofin crisis exposed the necessity to revamp this mode of governing through aggregate futures. ${ }^{78}$

\footnotetext{
${ }^{76}$ Bruno Latour, We Have Never Been Modern (Hemel Hempstead: Harvester Wheatsheaf, 1993).

${ }^{77}$ Mark Blyth, "When Liberalisms Change: Comparing the Politics of Deflations and Inflations," in Neoliberalism: National and Regional Experiments with Global Ideas, ed. Ravi K. Roy, Arthur T. Denzau and Thomas D. Willett (New York: Routledge, 2007), 78.

${ }^{78}$ The 2005 Reforms move from emphasizing a single indicator to a broader analysis of budgetary positions, including cyclical adjustments, a new methodology for establishing country-specific medium-term objectives (MTOs), and exceptions to the preventative measures.
} 
Unable to account for the heterogeneity underpinning the behaviour of Member States, risk "entails making calculable the uncalculable or the monitoring of contingency." ${ }^{, 79}$ Here the scientific knowledge of probabilities is of little utility as it cannot forecast individual propensities to act with any degree of precision. Quite often, these decisions are influenced by values and discursive factors that readily change and do not lend themselves to being assigned a concrete numerical quadrant that remains constant over time. Although Van Loon is correct to assert that "risks exist in a permanent state of virtuality and are only actualised through anticipation," the composition of that virtual state of being is never static since political culture is fluid. ${ }^{80}$ What we do not know may simply reflect the implicit diversity in the temporality of human conduct instead of some inescapable logic of reflexive modernity. Rather than seeking direction from models that neglect conditionality, a better mode of governance should take into account the often random character of uncertainty.

\section{Risk: The Operational Migration}

Deeply variable in both content and form, risk is dominantly embedded within the organisational infrastructure of the EU. The frequency and intensity of probable perils facing Europe have only increased with the degree of integration and interdependence. Cross border transactions have accelerated with the adoption of the common currency, making economic welfare an even greater derivative of forces outside national borders and control. Relinquishing monetary policy autonomy to the ECB, and thus the capacity to stabilise their economies through activist measures, such as the manipulation of exchange

\footnotetext{
${ }^{79}$ Scott Lash, "Reflexive Modernization: The Aesthetics Dimension," Theory, Culture and Society 10 (1993): 6.

${ }^{80}$ Joost Van Loon, Risk and Technological Culture: Towards a Sociology of Virulence, 2.
} 
rates, members must also now navigate the dense webs of horizontal and vertical integration. To address these coordinating dilemmas, new governance mechanisms have been designed (i.e. SGP, Open Method of Coordination). However, "the problem is that when everyone is responsible for delivering on a particular coordinating challenge, in practice no one is." ${ }^{81}$ So although government through risk is by no means uniform across problems, it works to stymie the tendency towards regulatory stagnation by "displacing valuable - but vulnerable - professional judgement in favour of defendable process" thereby "substituting risk management for political argument."

Mapping risk demonstrates the lineages where its inscription takes place. For all its supposed statistical intelligibility and congruence, this public fiscal-monetary space is an historical artefact derived from diverse set of influences. To understand how these shape "the conduct of conduct" and introduce parsimony into the management of European fiscal affairs requires a diagnosis of this very technocratic landscape. Although risk informs EMU policy, it is not indigenous to this space. In deciding upon the structures and processes underpinning EMU, its architects borrowed across multiple domains in their efforts to constitute a stable common economic space. Its migration from the corporate sector illustrates this point.

Recognising the intense debates surrounding the prioritisation of certain principles over others, this constellation of risk techniques has found expression in such narratives as the Single Market and common currency. To this extent, it has adopted the unrelenting calculations located in other areas of commerce to secure its objective. For example, inflation is conceived of as a potential and calculable failure, which if unmitigated can

\footnotetext{
${ }^{81}$ Andrew Jordan and Adriaan Schout, The Coordination of the European Union: Exploring the Capacities of Networked Governance (New York: Oxford University Press, 2006), xi.

${ }^{82}$ Michael Power, The Risk Management of Everything, 11.
} 
erode the value of the common currency, undermine the credibility of the ECB's monetary policy and destabilise the entire monetary union. In addition to these risks, exchange rates and the premia associated with interest rates are also transformed into risks amenable to mathematical computation. ${ }^{83}$ Arguably, all principal facets of EMU are subsumed within a framework emphasising performance and outcomes as is witnessed with private financial institutions. Together these amount to creation by the classification of causation.

Nowhere is this fascination with transforming organisational life into an objective measure of susceptibility more visible than in the insurance industry. ${ }^{84}$ Dating back to the latter seventeenth century, various structured forms of protection from liability began to surface. Merchants sought to guard against the threat of insolvency resulting from a naval catastrophe. Increasingly, factors, such as life expectancy or mortality, emerged as a discoverable body of knowledge. By the turn of the nineteenth century, risk developed into a social category for administrating populations. ${ }^{85}$

Nietzsche observed this development alleging that modern man is the embodiment of calculability. It is "by means of the morality of custom and the social straitjacket that man was really made calculable." ${ }^{, 86}$ Insurance is an institution where such applied knowledge finds expression. Equipped with a portfolio of probabilities derived from "scientific knowledge," both the private sector and governments deploy these technologies to structure the "pragmatic discourse of moral normalcy.", to Michael Power, that trumpets a "neoliberal morality of enterprise," which increasingly

\footnotetext{
${ }^{83}$ European Commission: DG for Economic and Financial Affairs, European Economy: Public Finances in EMU 2006, 143.

${ }^{84}$ Richard V. Ericson and Aaron Doyle, Uncertain Business: Risk, Insurance, and the Limits of Knowledge (Toronto: U of T Press, 2004).

${ }^{85}$ Pat O'Malley, Risk, Uncertainty and Government, 179.

${ }^{86}$ Friedrich Nietzsche, The Genealogy of Morals (New York: Oxford University Press, 1996), 40.

${ }^{87}$ Richard V. Ericson and Aaron Doyle, "Risk and Morality" in Risk and Morality, ed. Richard V. Ericson and Aaron Doyle (Toronto: U of T Press, 2003), 6.
} 
defines what constitutes as acceptable conduct through the use of probabilistically quantifiable formulas. ${ }^{88}$

Borrowing techniques from what was considered a more prudent and efficient private sector became more popular as "supply-side" economics penetrated the continent from the Anglo-American world. As methodological individualism and the rational-choice model gained traction so did strategies of risk management. Against the backdrop of the extremely volatile financial markets of the 1980s and the fears triggered by the collapses of, amongst others, Barings, Matellgesellschaft, and Long-Term Capital Management in the following decade, risk began to dominate the agenda of both private and public actors. With a calculus of probabilities at their disposal, EMU officials came to understand fiscal profligacy as a problem rooted in the language, ideas and methods of commercial risk management. So much so that risk began to displace other forms of understanding EMU governance, such as through the lens of national economic security or in terms of socioeconomic classes. ${ }^{89}$ In order to promote sustainable budgetary balances, a rules-based SGP depreciated the role of economic judgement and policy discretion. Surveillance rested on the Pact being transparent, consistent and equally administered in accordance to the quantitatively defendable process of risk. An arsenal of probabilistically predictive mechanisms was deployed to achieve these objectives.

New models of organisational discipline, intimately connected to these values of responsibility and performance, migrated from private banks as well as from the insurance, accounting and auditing industries into the EMU domain. Their purpose was to buttress the

\footnotetext{
${ }^{88}$ Michael Power, Organized Uncertainty: Designing a World of Risk Management (New York: Oxford University Press, 2007), 195.

${ }^{89}$ William Walters and Jens Henrik Haahr, Governing Europe: Discourse, Governmentality and European Integration.
} 
already visible capital market aversion to default risk. Monetarist by design, human discretion was removed wherever possible in favour of instruments aimed at maintaining low inflation, budgetary discipline and a stable currency. In this regard, "each of the Community's constitutive treaties facilitated the creation of a unified European market, while setting considerable institutional barriers to the regulation of that same market.",90 Risk was at the heart of these programmes; they envisioned EMU as a self-regulating and self-contained entity. Surprisingly, however, the discourse surrounding these calculative methods failed to problematise the performative practice of risk. Instead, risk has been accepted as a natural fixture of EMU governance. To dispel this misconception, this dissertation analyses European public sector management according to three primary organisational elements of risk.

\section{Internal Control}

The first concerns the emergence of risk-based "internal control" in redefining organisational governance. Initially of principal interest to the field of financial auditing, internal control systems have been expropriated as a governance mechanism not only to the entire corporation but to the "broader public space," thus equating them as "co-extensive with risk management. ${ }^{91}$ Mandated with creating value, financial institutions such as banks, are accountable for how they navigate their encounters with risk. They must exploit the neoliberal moral logic of opportunity mentioned above while disciplining themselves as not to jeopardise their chances for success. Internal controls are vital for this purpose.

\footnotetext{
${ }^{90}$ Mark Pollack, "A Blairite Treaty: Neoliberalism and Regulated Capitalism in the Treaty of Amsterdam," in European Integration after Amsterdam: Institutional Dynamics and Prospects for Democracy, ed. Karl-Heinz Neunreither and Antje Weiner (Oxford: Oxford University Press, 1999), 268.

${ }_{91}$ Michael Power, Organized Uncertainty: Designing a World of Risk Management, 35.
} 
Coherence reinforces the perception of internal control as a boundary object. By establishing common parameters, it consolidates risk objects within a rules-based system thereby enhancing their regulation. This occurs because the idea of self-regulation, based on mutual objectives, helps define the relationship that is necessary for maintaining an "efficient" and "profitable" operation. A garrison of mathematical weaponry typically calculates the exact variables denoting what these terms entail. Indicative of the shareholder model, the principle of ownership is the motivating factor. Having a stake in the performance of the organisation induces a voluntary norm that would otherwise be absent as it fosters a sense of identification with said body. Coupled with constant surveillance, the institutionalisation of normalising technologies produces calculable, semiautonomous objects/subjects of governance.

In the financial sector this mentality is quite pronounced. After all, substantial amounts of capital are at stake; as is the health of the economy. Firms cannot gamble with the potential for collapse by exposing themselves to unwarranted risks because of internal deficiencies. Even more disturbing is the idea of allowing human discretion to (mis)direct affairs. With this in mind and in the aftermath of "Black Monday" on October 19, 1987, which witnessed the Dow Jones Industrial Average (DJIA) plummet 22.6 percent, J.P. Morgan published its pioneering treatise establishing the industry-wide standard for calculating "Value-at-Risk" (VaR). ${ }^{92} \mathrm{VaR}$ is the quantile to the distribution of aggregate risk. It calculates the degree to which a business is susceptible to financial costs. With advances in computer modeling, "RiskMetrics" was the first technique to synthesise the multiple methods of calculating portfolio loss.

\footnotetext{
${ }^{92}$ Articulated in the 1993 publication entitled Risk Metrics. Value-at-Risk is considered a hybrid with various operational definitions. However, the primary objective is to measure the potential adverse financial costs to a portfolio of assets stemming from market fluctuations.
} 
Its value was attributed to the perception that this technology could forecast the precise numerical quadrant corresponding to "normal" market activity. Internal control is thereby enhanced as firms are better positioned to mitigate organisational risks. It involves:

assigning probabilities to future events, such as price changes and market movements, as well as forecasting the volatility of markets and correlations between various financial instruments held by the firm. ${ }^{93}$

Armed with such a devise, organisations can avoid pitfalls since their activities parallel the established economic normality. Should they succumb to risk, however, firms are also in a better position to withstand its adverse effects. Harry H. Panjer, a professor of Statistics and Actuarial Sciences at the University of Waterloo, notes that VaR not only provides risk estimations but it can also determine the amount of capital necessary to weather the storm in the event of a crisis. ${ }^{94}$ By this measure, it is vital to the integrity of internal controls as it characterises the acceptable levels of capital risk.

Holding a requisite amount of capital is particularly relevant to the banking industry. Inadequate reserves expose the bank to the risk of default and potential collapse. Such crises have adverse spillover effects that destabilise markets erasing volumes of wealth. Basel II is the framework that establishes the allocation levels for capital adequacy. ${ }^{95}$ VaR modeling is at the heart of this exercise. Issued in June 2004, Basel II

\footnotetext{
${ }^{93}$ Marieke de Goede, Virtue, Fortune, and Faith: A Genealogy of Finance (Minneapolis: University of Minnesota Press, 2005), 138.

${ }^{94}$ Harry H. Panjer, Operational Risks: Modeling Analytics (Hoboken, NJ: John Wiley \& Sons, 2006), 45.

${ }^{95}$ The Basel Committee on Banking Supervision has revised the original 1988 document with the intent to secure international convergence on revisions to supervisory regulations governing the capital reserves in order to strengthen the soundness and stability of the international banking system while maintaining a competitive environment. Liquidity rules are also been seriously considered.
} 
encapsulates many elements of the original 1988 version, which was written by seven of the initial twelve EMU members. ${ }^{96}$ It seeks:

to improve on the existing rules by aligning regulatory capital requirements more closely to the underlying risks that banks face. In addition, the Basel II Framework is intended to promote a more forward-looking approach to capital supervision, one that encourages banks to identify the risks they may face, today and in the future, and to develop or improve their ability to manage those risks. As a result, it is intended to be more flexible and better able to evolve with advances in markets and risk management practices. ${ }^{97}$

Throughout this document the language of risk is constantly visible.

In fact, it is primarily about risk as banking has evolved to operate and profit on the margins assigned to these probabilities of misfortune. Interest rates symbolise these instances. Knowledge of these figures simply allows organisations to design internal controls that squeeze these margins to the greatest extent possible. Then they breach into excess. ${ }^{98}$ But without perfect knowledge of future variables, VaR models are based on a mentality of estimation. They represent a future that is yet undetermined but constantly being constructed on the basis of subjective perceptions. Unfortunately, this element is rarely acknowledged by the conventional literature.

These internal control systems render risks governable as they interpret and reveal information about economic activity and encourage self-monitoring. But as opposed to mandating compliance, internal control governmentality focuses on organisational design and procedural issues in the creation of, what Deleuze and Guattari call, a "strained

\footnotetext{
${ }^{96}$ The United Kingdom and Sweden also played a role in developing EMU though they did not adopt the euro. Belgium, Canada, France, Germany, Italy, Japan, Luxembourg, the Netherlands, Spain, Switzerland, and the United States are the other members that compose the Committee on Banking Supervision.

${ }^{97}$ Bank for International Settlements, "Basel II: Revised international capital framework," available from http://www.bis.org/publ/bcbsca.htm.

${ }^{98}$ US subprime woes and the asset backed commercial paper (ABCP) based on residential mortgages exemplifies this kind of behaviour.
} 
space." 99 Here the logics of control target capacities and potentialities as authorities monitor the capability of actors to self-regulate themselves. This renders the subject within an organisation visible as an object of control. Such is the case because in a neoliberal society these control mechanisms rest upon the understanding that numbers represent a factual world, which is itself calculable. What develops is the "control-of-control" or a form of "metagovernance" where:

the calculated modulation of conduct according to principles of optimisation of benign impulses and minimization of malign impulses is dispersed across time and space of ordinary life. ${ }^{100}$

Yet, unlike the role Rose attributes to "politically salient numbers" in democratic society, this form of power remains unproblematised and outside public discourse. ${ }^{101}$ Numbers are no longer questioned but accepted "with a significant degree of uncritical trust.",102

EMU epitomises this space, which is "measured, directed and standardized as opposed to nonmetric, rhizomic and acentred," by continually becoming susceptible to regulation. ${ }^{103}$ Aside from the latitude relished by national fiscal authorities, the European System of Central Banks (ESCB) is an example of metagovernance in action. Lacking a legal personality or the governmental structure of its constituent bodies (the ECB and all 27 National Central Banks (NCB)), the ESCB is the decentralised monetary authority of the euro area. Its independence from other community bodies (i.e. Commission, Member States) was established by the Rome I European Council granting it the power to modulate

\footnotetext{
${ }^{99}$ Gilles Deleuze and Felix Guattari, A Thousand Plateaus: Capitalism and Schizophrenia II (Minneapolis: University of Minnesota Press, 1987): 474-500.

${ }^{100}$ Nikolas Rose, Powers of Freedom, 234.

${ }^{101}$ Nikolas Rose, "Governing by Numbers: Figuring out Democracy," Accounting, Organizations and Society 16, no. 7 (1991): 673 .

${ }^{102}$ Robert Deuchars, The International Political Economy of Risk: Rationalism, Calculation and Power, 68.

103 Andrew Barry, "Lines of Communication and Spaces of Rule," in Foucault and Political Reason: Liberalism, Neo-liberalism and Rationalities of Government, ed. Andrew Barry, Thomas Osborne, and Nikolas Rose (Chicago: The University of Chicago Press, 1996), 128.
} 
conduct which threatens to jeopardise the goal of price stability. ${ }^{104}$ Within such a regime of surveillance is the constant monitoring and management of risk. Control "flows through a network of open circuits that are rhizomatic and not hierarchical" as the ECB and NCBs perform tasks in collaboration but without a coercive impediment in regards to policy decisions. ${ }^{105}$ All elements within the ESCB strive to reign in inflationary pressure by keeping its rate below, but close to, 2 percent over the medium-term. ${ }^{106}$ Power is diffusely distributed in this configuration, where the ESCB functions as a network of perpetual risk assessment and management.

Early warning systems, such as those employed by Ecofin, under Article 99(4) of the TEU, also externalise internal control arrangements as they monitor for budgetary positions that "are not consistent with the broad guidelines or risk jeopardising the proper functioning of EMU." To buttress its relative position in the Stage III surveillance process, DG EcFin underscores the significance of cyclical economics and econometric budgetary forecasting in the early warning alerts issued by Ecofin on the Commission's recommendations. Simultaneously embodying and constituting the objects of governance, internal controls "translate primary risks into systems risks," thereby allowing EMU to standardise its approach to potential dangers. ${ }^{107}$ Codified in Council Regulation 1466/97 as part of the "preventative arm," this procedure connects various regulatory bodies which would otherwise be fragmented. Order is established across multiple sites within EMU

\footnotetext{
${ }^{104}$ David Howarth, "EMU, Integration Theories, and the Annoying Complexities of French Policy-Making," in The Euro: European Integration Theory and Economic and Monetary, ed. Amy Verdun (Lanham, Md.: Rowman \& Littlefield Publishers, 2002), 93.

${ }^{105}$ Nikolas Rose, Powers of Freedom, 234.

${ }^{106}$ European Central Bank, "Monetary Policy," available from http://www.ecb.int/mopo/html/index. en.html; And: "without prejudice to the objective of price stability, the ESCB shall support the general economic policies in the Community with a view to contributing to the achievement of the objectives of the Community as laid down in Article 2" (Treaty article 105.1). The objectives of the Union (Article 2 of the Treaty on European Union) are a high level of employment and sustainable and non-inflationary growth. ${ }^{107}$ Michael Power, The Risk Management of Everything, 24.
} 
through the coordination of resources in the identification and monitoring of risks before they happen. Unfortunately, this logic proved fallible in 2003 as it failed to forecast and prevent the integration of the Pact.

Mathematical classifications are the defining feature embedded within "the respecification of the problem of control as a problem of risk management" at the level of the organisation. ${ }^{108}$ In the aftermath of the SGP crisis, however, it is human discretion that is becoming more pronounced in mediating how to regulate these at the network level. In short, internal control is a principal process that is transforming organisations according to the logic of "enforced self-regulation." Emerging in precise sites and at specific historical moments, internal control proceduralises risk through a network of discursive practices. As a management tool, it exerts "isomorphic pressure" across organisations to conform to the neoliberal orthodoxy underpinning strategic normalcy. ${ }^{109}$ How this is achieved exposes the rubric of operational risk. Problematising this dimension of risk management occupies the next section.

\section{Operational Risk}

Perpetual tensions between attempts to maintain control through an expansive knowledge of risk and the entrepreneurial gains from uncertainty have created new categories for designating managerial conduct. Operational risk is one of these inventions.

Instrumentalising neoliberal engrossment with rendering visible, and therefore manageable, all unknowns, it also functions as a boundary object uniting dispersed sites together under a specific category of intervention. Similar to internal control, the political economy of

\footnotetext{
${ }^{108}$ Nikolas Rose, Powers of Freedom, 263.

${ }^{109}$ Kevin T. Leicht and J. Craig Jenkins, "Political Resources and Direct State Intervention: The Adoption of Public Venture Capital Programs in the American States, 1974-1990," Social Forces 76, no. 4 (1998): 1325.
} 
regulation that operational risk is implicated in has the calculation of economic capital at its core. However, these probabilities represent non-financial risks. Its variable form makes providing a concise and uncontestable definition problematic; something which is characteristic of risk in general. But perhaps a broad definition, offered by the Basel Committee, includes the risk of "loss arising from various types of human or technical error" and "typically measures of internal performance, such as internal audit ratings, volume, turnover, error rates and income volatility, rather than external factors." ${ }^{110}$ Its nebulous nature stems from the fact that operational risk is constantly developing as a rationality of government.

Notwithstanding, certain "event types" of operational risk have been identified by the Basel Committee that may contribute to the losses suffered by an organisation. Ranging from "internal fraud" to the "damage of physical assets" resulting from natural calamities, these are all framed in terms of capital management. ${ }^{111}$ In the first instance, this appears as quite the banal statement since this is a staple of neoliberal society. Many of these classifications have come to be considered as self-evident. Their basis in numerical form only reiterates this point. As Deuchars suggests, "this is a form of rule that has been fostered, promoted, and inserted into society not explicitly, but slowly over time, becoming thus part and parcel of everyday human interaction."112 Of course, these sorts of statements need to be problematised in order to reveal the sedimentation of the particular systems of power that they reflect. Questions of how the operational infrastructure of EMU facilitates

\footnotetext{
${ }^{110}$ Basel Committee on Banking Supervision, "Operation Risk Management," available from http://www.bis.org/publ/bcbs42.pdf?noframes=1. Examples of external factors would include market price movements or a change in a borrower's condition.

${ }^{111}$ Basel Committee on Banking Supervision, "Sound Practices for the Management and Supervision of Operation Risk," Bank of International Settlements (2003), available from http://www.bis.org/publ/bcbs96. pdf.

${ }_{112}$ Robert Deuchars, The International Political Economy of Risk: Rationalism, Calculation and Power, 68.
} 
such embeddedness and what this means for how governance is practiced are at the core of this dissertation.

Many of these operational governance mechanisms have developed in the area of international banking. Among these is the "prudential regulation" approach. Its primary emphasis is on financial stability rather than the design of rules regulating financial flows across borders. Undoubtedly, the recent credit crisis is fuelling demands to implement prudential reforms that would minimise the probability of future bank failures and systemic instability. Clear and transparent rules need to be established so that compliance can be easily monitored. Though who benefits from this approach is highly contentious.

On the one hand, there are governing agencies that prefer the conservative "command-and-control" programme for its greater managerial scope. Specific capital-toasset ratios endow national regulators with a fair degree of control over their banking sectors. Lacking the authority to issue these mandatory directives or impose sanctions, the Basel Committee is significantly more dependent on voluntary acceptance of its recommendations than its national counterparts. ${ }^{113}$ On the other hand, there are entrepreneurial bankers who consider these capital adequacy ratios excessive restrictions that place their firms at a competitive disadvantage. Anglo-American banks favour a lower benchmark than their continental rivals. Initially 20 percent was proposed for the minimum capital reserve ratio but it was subsequently trimmed to 12 percent. In the end, banks were required to a hold total capital equivalent to at least 8 percent of their risk-weighted

\footnotetext{
${ }^{113}$ Martin Marcussen, "The Basel Committee as a Transnational Governance Network," in Democratic Network Governance in Europe, ed. Martin Marcussen and Jacob Torfing (New York: Palgrave Macmillan, 2007), 214.
} 
assets. ${ }^{114}$ The neoliberal mentality was becoming more pronounced across the banking industry.

All this culminated in 1996 when "in-house models" were officially sanctioned by the Basel Committee. The political economy of banking regulation changed to accommodate "enforced self-regulation" as a central tenet. Otherwise referred to as "Pillar 1," it entrusted individual banks with devising proper regulatory schemes since it was these banks that were in the best position to assess their own conduct and its derived risks.

Together with "Pillar 2," which addresses supervisory oversight of the control environment, a new "practical and managerial narrative" was constituted. ${ }^{115}$ It reflects this antagonistic relationship between the programmatic and functional dimensions of organisational life. Behavioural risks can always jeopardise the execution of any business plan. Identifying and classifying loss inflicting events, which were considered empirically incalculable, constructs a regulatory space where these objects of government are drawn into and repositioned. They now become manageable as "the institutional visibility of these risk objects has been re-constructed within the discourse of operational risk."

In this neoliberal environment the discursive practice of "taming through naming" often satisfies the governmental desire for control. Once a new idea is introduced into the governing constellation as an object, "new possibilities for action come into being in consequence."117 Such animation transforms "killer events" and incalculable risks into

\footnotetext{
${ }^{114}$ Basel Committee on Banking Supervision, "Basel II: International Convergence of Capital Measurement and Capital Standards: A Revised Framework," Bank of International Settlements (2005), available from http://www.bis.org/ publ/bcbs118. pdf?noframes=1; this reflected the original 1988 document.

${ }_{115}$ Michael Power, Organized Uncertainty: Designing a World of Risk Management, 110.

${ }^{116}$ Michael Power, Organized Uncertainty: Designing a World of Risk Management, 125.

${ }^{117}$ Ian Hacking, "Making Up People," in Reconstructing Individualism: Autonomy, Individuality and the Self In Western Thought, ed. Thomas C. Heller, Morton Sosna, and David E. Wellbery (Stanford, CA: Stanford University Press, 1986), 231.
} 
"routines, regulations and data collection processes." 118 These socio-technical systems increase information flows thereby exposing the regulated space in question to further manipulation. Echoing Timothy Mitchell, "political power now has a new form: the knowledge and command of space." 119 Incrementally, as various operational dimensions are defined through risk rather than uncertainty the associated myths of control are reinforced. Granted that a "killer event" is actually mitigated through these techniques there is little to fret about. What is gravely disturbing is the occurrence of a crisis, such as the SGP debacle. As a misguided approach, the original Pact was an inadequate system that only aggravated the operational dangers facing itself.

\section{Reputational Risk}

Finally, the category of "reputational risk" connects the question of legitimacy and power with organisational identity. Adverse spillover effects quite often extend beyond the initial activity and are amplified by the intangible asset of reputation. A tarnished and poor opinion may only confound the task of rebuilding and reconstituting a legitimate semblance of control after a catastrophe or organisational failure. Reputation is particularly significant for the sustainable management of risk because it provides speculation with political legitimacy. Connecting reputation with notions of responsibility opens up new contested spaces where governance may be imagined, constructed and eventually legitimated. Simultaneously, the "logic of consequences" anchored in rational expectations confronts and overlaps a "logic of appropriateness," which articulates norms of proper behaviour. Risk-centered technologies of government simply entrench these mentalities within

\footnotetext{
${ }^{118}$ Michael Power, Organized Uncertainty: Designing a World of Risk Management, 25.

${ }^{119}$ Timothy Mitchell, Rules of Experts: Egypt, Techno-Politics, Modernity (Berkeley: University of California Press, 2002), 90.
} 
calculative persons and organisations. Together they produce the growing leverage of "reputational capital" and the devolution of legitimate forms of power. ${ }^{120}$

Legitimacy demands a certain level of transparency and trust. Based on performance and communication, stakeholders, and especially shareholders, are capable of assessing whether an organisation fulfills its objectives and the exposure to risk that this entails. A reputable opinion is vital for the success of a firm as it competes to attract investment in the face of globally mobile capital. Not only does it determine its cost of operations and subsequent profits but also its very survival. Hence, there is an impetus for devising and maintaining credible frames that are easily understood and persuasive. From this perspective, the legitimacy of an organisation corresponds to how the broader community accepts the existing frames. After all, in a neoliberal environment that endorses strict notions of corporate valuation it is only sensible to expect "value for money" judgements.

But irrespective of the intensity and frequency involved in the effort to convert reputation into an object of risk through mechanisms such as metrics and rankings, it is not simply an uncontestable calculation. Organisational practices:

that are subject to constraint via mechanisms of 'external' or stakeholder accountability therefore emerge as a product of pragmatic political compromise, and remain largely discretionary in scope and substance. ${ }^{12 \mathrm{I}}$

Since framing is deeply implicated in a cultural economy, it represents heterogeneous logics and discourses. Locating uniformity is futile because it simply does not exist.

\footnotetext{
${ }^{120}$ Michael R. MacLeod, "Financial Actors and Instruments in the Construction of Global Corporate Social Responsibility," in Global Accountabilities: Participation, Pluralism, and Public Ethics, ed. Alnoor Ebrahim and Edward Weisband (New York: Cambridge University Press, 2007), 246.

${ }^{121}$ Kate Macdonald, "Public Accountability within Transnational Supply Chains: A Global Agenda for Empowering Southern Workers?" in Global Accountabilities: Participation, Pluralism, and Public Ethics, ed. Alnoor Ebrahim and Edward Weisband (New York: Cambridge University Press, 2007), 266.
} 
However, this is not to discount the potential for consensus. Rather it merely recognises that repositioning reputation as a managerial process entails problematising how normalcy, as a precursor for convergence, is determined.

Of course, constructing social perception is not straightforward. It often hinges on an inherent tension between varying and conflicting channels of communication as well as their distinct languages, which seek to identify measure, describe and classify it. Symbolism is pivotal to this endeavour. For this reason, I prefer to adopt Rao's definition of reputation. It is the process of "creating an account of an organisation, embedding that account in a symbolic universe, and thereby endowing the account with social facticity.", 122 This should not be confused for a universal ontology asserting certain natural properties. Instead, reputation is an unstable and fluid designation assigned to behaviour which allows us to think of risk in how we govern. It is an asset, albeit an intangible one, that is marketed for managerial purposes and the establishment of a brand. Labelling an individual, firm or government economically profligate is a particular act of representation that can evoke a reaction from the markets and other actors. Efforts to engineer an efficient and profitable outcome assume an assemblage of practices and techniques that grants authority to such value assignments. Quantitative modeling, being the signalling technology, is endowed with the power to create this politico-economic formation. Risk is the calculative rationality underpinning such management. ${ }^{123}$

Accounting along with credit ratings, performed by agencies the likes of Standard \& Poor's or Moody's, are tools that embody this management mentality. They transform

\footnotetext{
${ }^{122}$ Hayagreeva Rao, "The Social Construction of Reputation: Certification Contests, Legitimation, and the Survival of Organizations in the American Automobile Industry: 1895-1912,' Strategic Management Journal 15 (1994): 31.

${ }^{123}$ Mitchell Dean, Governmentality: Power and Rule in Modern Society, 178.
} 
actors into self-evaluating units geared to producing predetermined rates of return. Straying away from these targets constitutes poor and abnormal behaviour as expectations of what is appropriate are transgressed. A sullied reputation follows. Peter Miller connects this image of accounting to "liberal" forms of government that celebrate the capacity of individuals to construct a "free market." 124 Appealing to the freedom of subjects to fulfill the laws of supply and demand, accounting and credit ratings play a performative role as they help quantify what is considered normal and good conduct in terms of an accessible economic figure.

Rankings often produce discrepant if not conflicting reports as their methodologies and languages differ. Nevertheless, being open to and in fact favouring external scrutiny has itself become a litmus test of good conduct. Even before succumbing to procedures of verification simply the willingness to undergo evaluation enhances reputational capital. Within this constellation of expertise and risk-centred strategies of government, benchmarks are deployed as a primary tool in the remanagerialisation of risk. ${ }^{125}$ Actors remain autonomous but embedded in ranking systems that make them transparent and measurable as performance indicators. All the:

league tables, rankings, and indices construct self-reinforcing circuits of performance evaluation, thereby perpetuating the internal importance of externally constructed reputation and giving to reputation a new governing and disciplinary power. ${ }^{126}$

Ambiguity is regarded as dangerous as it hampers the capacity for proper calculation and increases the perception of "being at risk." Therefore, organisations and individuals submit to these kinds of measures as they welcome being evaluated. Doing so, however, simply

\footnotetext{
${ }^{124}$ Peter Miller, "Governing by Numbers: Why Calculative Practices Matter," Social Research 68, no. 2 (2001): 389-96.

${ }^{125}$ Michael Power, The Audit Society: Rituals of Verification (New York: OUP, 1999), 1-14.

${ }^{126}$ Michael Power, Organized Uncertainty: Designing a World of Risk Management, 141.
} 
means that they further implicate themselves in power relations that steer them according to specific risk vectors.

Two effects may be observed with this process. While reputational risk management:

helps to fabricate and extend practices of individualization and responsibility ....it also serves to establish a mutuality or reciprocity between forms of personal identity and the realm of economic calculation...thus helping to create the calculating self as a resource and an end to be striven for. ${ }^{127}$

Here the identity of the subject is intimately linked to a regulatory process that seeks to maximise reputational capital. Its sense of self becomes implicated in economic definitions of legitimacy. Attempts to internalise external metric elements lead to the perception of oneself as a performance variable. Concurrently, by rendering calculable the operations of its freedom, the subject is standardised as a risk object of governance. A calculative logic is cemented in both subjectivity and the act of government.

Overall, fiscal management does not lend itself to the same techniques applied in the monetary sphere or financial markets. Transposing a risk management system onto the fiscal domain has proved a persistent challenge for the architects of EMU. Averages anchored in discourses of normality prove ineffective in describing or eradicating the vast differences between Member States. New terms and approaches are necessary for comprehending how the EMU space develops through alternative modes of regulation. Conventional IR theories fail to recognise these objections against the standardisation of normalcy. All too often, the programmatic dimensions of fiscal relations or how they are framed and regulated through particular modes of governance are either misconstrued or completely neglected. Conversely, the governmentality approach allows us to move beyond

${ }^{127}$ Peter Miller, “Governing by Numbers: Why Calculative Practices Matter," 381. 
the misguided debate of whether risk and uncertainty are either analytically real or unreal. In turn, we come to understand how these modes facilitate the interpretation of the SGP problematic and subsequent construction of this emerging spatial-temporal order.

\section{Uncertainty: The Analytical and Conditional}

Stating that the evidence of monetarist homogeneity is not as convincing as originally purported, I want to stress that this movement to uncertainty-based discourses and technologies does not completely displace those rooted in risk and probabilistic power. In fact, risk analysis still plays a significant role in estimating and determining fiscal and monetary policy. Various instruments employed by the ECB, from inflation targeting to open market operations, are conducive to governing through risk as enough adequate information may be accumulated and synthesised to render an indicator fairly accurate. ${ }^{128}$ The new methodology for computing "minimum benchmarks" is another example where statistical methods are still useful tools in the provision of a structural budgetary position consistent the 3 percent reference value. Undoubtedly crucial to the operations of EMU, these occupy a less temperamental tier of decision-making than those undertaken by Ecofin and thus one that is not as precarious to its integrity. However, even these techniques are observant of individual "budgetary sensitivity," which addresses cyclical fluctuations. ${ }^{129}$

Detaching "the substantive authority of expertise from the apparatuses of political rule," as qualculation accomplishes, risk re-inscribes government-at-a-distance. ${ }^{130}$ Autonomous of central control, it is "a system which aims to transform its participants into

\footnotetext{
${ }^{128}$ Barry Eichengreen, "Europe, the Euro and the ECB: Monetary Success and Fiscal Failure," Journal of Policy Modeling 27 (2005): 427-39.

${ }^{129}$ European Commission: DG for Economic and Financial Affairs, European Economy: Public Finances in EMU 2007, 93.

${ }^{130}$ Nikolas Rose, "Governing 'Advanced' Liberal Democracies," 41.
} 
'calculative individuals' within a specific 'calculative space,' namely the notion of a European economy." ${ }^{131}$ This performative character of risk enables it to create responsible actors and organisations. Now behaviour may be managed according to prescribed and standardised quantitative targets and norms. Unfortunately, qualculation allows European economic and monetary government to be taken for granted and distinct from its discursive practices of representation. It fails to address the contingency inherent in the political character of the project; namely "how men govern by the production of truth.", 132 Instead, what is offered is a pre-packaged notion of how organisational life is to develop.

Although risk is not indigenous to this domain, having migrated from the corporate sector, as a rationality of government it informs a slew of technologies geared to producing normal and responsible economic objects of government. One may say that the "European Union is an unusually heterogeneous arrangement of elements."133 Following Deleuze by evoking the technical connotation of "arrangement," Andrew Barry persuasively argues that government does not lead to a reduction in complexity. Differences are not eradicated with the application of models of metrication. Although European integration is heralded as a "metric political system writ large," standardised measurement systems, affinitive to risk analysis, often fail to consolidate the entire territory of government. ${ }^{134}$ Rather there remain significant variations in the articulation of EMU as well as its practices. Again, one only has to look to the SGP crisis to acknowledge such diversity and contestation.

\footnotetext{
${ }^{131}$ William Walters and Jens Henrik Haahr, Governing Europe: Discourse, Governmentality and European Integration, 125.

${ }^{132}$ Michel Foucault, "Questions of Method," in The Foucault Effect, ed. Graham Burchell, Colin Gordon, and Peter Miller (Chicago: Chicago University Press, 1991), 79.

${ }^{133}$ Andrew Barry, "In the Middle of the Network," in Complexities: Social Studies of Knowledge Practices, ed. John Law and Annemarie Mol (Durham: Duke University Press, 2002), 143.

${ }^{134}$ Ibid, 143.
} 
Simply attempting technocratic control of something as multifarious and fluid as the socio-political conduct of EMU is virtually impossible. One cannot aggregate and preempt all the available combinations that factor into a decision-making process.

Predictability is challenged by an "imprecisely foreseeable future," which is not repeating itself in any statistically measurable way. ${ }^{135}$ Furthermore, to treat risk management solely as a technical analytical process is to neglect the values and norms it embodies. One of the most visible of these ideals, in the context of EMU, is the discourse of normalcy as a precursor for convergence. Thus, rather than defining this lack of secure knowledge as a type of incalculable risk, which is merely unknown, another analytical, as well as governmental, category is necessary to establish this normative anchor for fiscal relations.

To remedy this inadequacy is to recognise uncertainty and deploy alternative, largely non-quantitative and non-aggregating forms of knowledge that "make demands on entities to exercise their foresight in enterprising ways." ${ }^{136}$ Not only is this more consistent with the actual operational dimension of EMU but it also explores how truth claims are conditioned by changing articulations and forms of power; thus accounting for their contingency. As such, governmentality reveals that, although the fundamental philosophy behind the EMU remains essentially unchanged by the crisis, the subsequent 2005 reforms reflect a significant shift in the management of fiscal relations; namely from governing through risk to that of uncertainty.

Now that we understand how risk gained traction in the context of EMU, I turn to analyse how surveillance as regulation has transformed with this transition to uncertainty.

\footnotetext{
${ }^{135}$ Pat O'Malley, "Moral Uncertainties: Contract Law and Distinctions between Speculation, Gambling, and Insurance," in Risk and Morality, ed. Richard V. Ericson and Aaron Doyle (Toronto: U of T Press, 2003), 235.

${ }^{136}$ Richard Ericson, "Governing through Risk and Uncertainty," Economy and Society 34, no. 4 (2005): 660.
} 
Keeping in mind that uncertainty is often misrepresented as risk, I unpack uncertainty to reveal its distinct conceptualisation and effects on the political economy of EMU. In a similar vein to risk, uncertainty is a problematising activity. It is aimed at addressing the problems of variability and diversity implicit in governing this fiscal-monetary space according to various logics of control and responsibility. To govern through uncertainty is to do so:

in non-quantitative ways, by reference to experienced judgment, shred guesswork, rules of thumb, analogies and so forth. By implication, uncertainty therefore is a way of governing futures that are imagined as singular, infrequently recurring or unique. ${ }^{137}$

Creative thinking reasserts its value in relation to risk management, which may be considered an exercise in the application of predefined quadrants. In the process, expertise is reconfigured as it seeks to cope with the flexible dimension of fiscal relations.

This involves "the mobilization of the perception of crisis" in the attempt to "find and construct points of resonance with a multitude of individuated experiences." 138 Unless this mobilisation and instrumentalisation of expert authority can succeed in promoting some form of alignment amongst disparate EMU entities, the prospects for a common monetary union looks rather dim. Because of the unique contingencies implicit in the SGP, surveillance must adapt to monitor individual state propensities towards fiscal profligacy. Increasingly, it depends more on creative foresight rather than probabilistic modelling to ascertain what normalcy entails. This produces variegated prescriptions of responsibility that the EU can use as a leverage to control budgetary conduct. The objective is to foster an enhanced sense of fiscal ownership. Thus, the Pact may be perceived as a device that acts

\footnotetext{
${ }^{137}$ Pat O'Malley, Risk, Uncertainty and Government, 13.

${ }^{138}$ Colin Hay, "Crisis and the Structural Transformation of the State: Interrogating Processes of Change," British Journal of Politics and International Relations 1, no. 3 (1999): 321.
} 
upon Member States in the attempt to constitute them as specific economic objects of government susceptible to the programmatic ambitions it embodies. Through this subjectification process a leverage of control is exerted to modulate EMU subjects into compliance.

Although the majority of the IR discipline is dismissive of the analytical value of risk, it is even more ambiguous about uncertainty. ${ }^{139}$ Of course, there is a considerable effort to transform a domain of insecure knowledge into quantifiable regularities that may be mitigated through programmes and technologies of risk management. Governance depends on the capacity to render estimations of the future into a calculable form. Even here, however, it would be misleading to claim that there is a uniform consensus on how these concepts are understood and operationalised. Nevertheless, uncertainty does differ from risk as it depends more on creative foresight instead of probabilistic modelling. Statistical data and computations continue to be employed but their utility is very much in question in situations where a calculable probability distribution cannot be assigned.

Uncertainty represents a shift to government through singular futures. As a modality of rule, it harnesses this enterprising potential as a pragmatic response to an indeterminate future. Demands that Member States balance the goals of fiscal austerity with those of broader economic growth and employment - identified in the Lisbon strategy - target their skills to adequately diagnose these challenges and institute successful measures to solve them. Calling into question what is legitimate, this is conditional on a social dimension being (re)introduced into the imagination of how this emerging spatialtemporal order is governed

${ }^{139}$ Darryl S.L. Jarvis and Martin Griffiths, "Risk and International Relations: A New Research Agenda?” 1. 
To distinguish uncertainty from risk in this manner is not conventionally preferred by much of the existing literature. Lacking a systemic theory on which to ground the uncertainty problematic, a transdisciplinary approach is adopted borrowing the insights of other disciplines in order to explain politico-economic phenomena in EMU. ${ }^{140}$ Sociologists have been at the forefront of researching the government through risk and uncertainty. ${ }^{141}$ In particular, it is from the field of economic sociology that I borrow in the development of my argument.

The problem of uncertainty has entered the discourse of many disciplines and has been appropriated in diverse ways. In economic theory it is typically associated with marginal utility and modelling optimal allocation equilibria. ${ }^{142}$ Knight distinguished between risk and uncertainty in his analysis of profit in market economies. He took exception to the "practical omniscience" of every actor in the market purported by economic orthodoxy. ${ }^{143}$ Uncertainty is the inescapable reality of entrepreneurialism. Unique business decisions are subject to imperfect information about the future. This hinders one's decision-making capacity as expected utility-maximisation is inapplicable in various stages of economic life where uncertainty prevails. Definite numerical probabilities cannot be assigned to outcomes because agents lack a clear notion of the possible consequences of their actions. Not knowing what causal relations maximise utility jeopardises rational actor modelling of a predictive Pareto-efficient equilibrium. Nevertheless, the:

\footnotetext{
${ }^{140}$ Robert Deuchars, The International Political Economy of Risk: Rationalism, Calculation and Power, 3.

${ }^{141}$ Ulrich Beck, Anthony Giddens, and Scott Lash, Reflexive Modernization; Ulrich Beck, World Risk Society; Richard V. Ericson and Aaron Doyle, Uncertain Business: Risk, Insurance, and the Limits of Knowledge.

${ }^{142}$ Kenneth J. Arrow and Gerald Debreu, "Existence of an Equilibrium for a Competitive Economy," Econometrica 22, no. 3 (1954): 225-90; Edmond Malinvaud, "First Order Certainty Equivalence," Econometrica 37, no. 4 (1969): 706-718.

${ }^{143}$ Frank Knight, Risk, Uncertainty and Profit (New York: A.M. Kelley, 1921/1964), 197.
} 
'degree' of certainty or of confidence felt in the conclusion after it is reached cannot be ignored, for it is of the greatest practical significance. The action which follows upon an opinion depends as much upon the amount of confidence in that opinion as it does upon the favourableness of the opinion itself. $^{144}$

Calculations do occur, but in the form of critical judgements emphasising the success of the estimate more so than the actual outcome itself. Often these are reinforced by the "shared mental models" that actors subscribe to, which are cognitive practices used to interpret uncertain environments and discern interests. ${ }^{145}$

Denzau and North address this point but their contribution is mainly limited to the realm of ideas. Aside from some marginal comments about institutions, they fail to adequately explicate how these mental constructions are actually translated into practice. By neglecting the materiality of discourse while privileging ideas in the construction of social structures rather than explaining how they are produced and negotiated, Denzau and North are prone to idealism. Calculative practices articulate governmental programmes and shape the economic and social relations that comprise the EMU regulatory space. How these socially constructed truths form in the context of the SGP through specific institutional and historical practices is what this dissertation helps to understand.

Sympathetic to Knight's approach, Keynes believed that uncertainty eliminates the numerical measure of incidence preventing the forecasting of such things as prices, war or future interest rates. ${ }^{146} \mathrm{He}$ also echoed the sentiment that irrespective of the absence of calculable probability:

the necessity for action and decision compels as...to overlook the awkward

\footnotetext{
${ }^{144}$ Ibid, 227.

${ }^{145}$ Arthur T. Denzau and Douglass C. North, "Shared Mental Models: Ideologies and Institutions," Kyklos 47, no. 1 (1994): 3-5.

${ }^{146}$ John Maynard Keynes, Treatise on Probability (London: MacMillan, 1921, AMS Press Reprint, 1979).
} 
fact and behave exactly as we should if we had behind us a good Benthamite calculation of a series of prospective advantages and disadvantages, each multiplied by its appropriate probability, waiting to the summed. ${ }^{147}$

Without the certainty provided by equivalence, the conventional economic orthodoxy is undermined as uncertainty questions the integrity of its decision-making capacity. ${ }^{148}$ Knight and Keynes both assert that uncertainty is a constant facet of economic activity. Their predictions rest on numerous assumptions that are seldom problematised but readily transposed from one context to another. Employing "aids," such as the ceteris paribus clause, economists "cling most tightly to the promised certainties of atemporal structuralisms and positivist methods. ${ }^{, 149}$ Incorporated with the very state-centric IG ontology, politics, not to mention society, become excluded and subservient to liberal economic theory. Even more distressing is the absence of a genuine interest theory as preferences are exogenous to these models. Without any serious discussion about interest or identity formation, the IG approach must rely on predetermined categories and false dichotomies. Positivistic readings neglect the epistemological implications of their own endeavours in favour of methodological rigour and ontological inventions. But how problems are framed, especially when contingency and speculation are factors, requires that those involved in doing so be sensitive to the conditionality, reactivity, and interactivity the social dimensions - of both uncertainty as well as risk.

\section{Uncertainty: Operational Dynamics}

As a constellation of unique political, economic, and social forces, EMU's success is contingent upon correctly assessing and managing the challenges which result from their

\footnotetext{
${ }^{147}$ John Maynard Keynes, “Theory of Employment," Quarterly Journal of Economics 51, no. 2 (1937): 214.

${ }^{148}$ Jens Beckert, Beyond the Market: The Social Foundations of Economic Efficiency (Princeton, N.J.:

Princeton University Press, 2002), 42.

${ }^{149}$ Robert B.J. Walker, Inside/Outside: International Relations as Political Theory, 105.
} 
interplay. Framing the EMU problematic through uncertainty is an effort to redefine this operative discursive field and come to terms with the antagonistic relationship between its programmatic and operational components. A genealogical approach reveals the lineages where such inscription takes place. Through the deconstructive and reconstructive themes explored in this dissertation, we come to understand EMU as continually constituted and renegotiated by the practices of self-regulating networks geared to mitigating future dangers through present techniques. This illustrates is the growing (re)politicisation of fiscal governance in Europe. With more latitude to problematise their unique situations, governments are finding new spaces of opportunity and responsibility are opening up, previously monopolised by risk technologies.

Uncertainty is central to helping reengineer normal and responsible fiscal relations in the aftermath of what is, arguably, the most severe blow to the ideological and institutional integrity of this fiscal-monetary space. More conducive to the government through singular rather than aggregate futures, this restitutory process needs to account for the heterogeneity of Europe's fiscal landscape. To do so is to be cognisant of how expertise is (re)conceptualised and practiced within EMU. By extending deadlines to correct excessive deficits or including more discretionary applications of the rules, the new SGP anchors expertise back in human critical judgement, endowing it with an enhanced status and authority. In this context, experts still exercise a substantial amount of power but their methodology in arriving at their conclusions is changing. As such, a reflexive element is infused into the government of EMU, making it susceptible to competing interpretations of what constitutes proper budgetary conduct. We have to simply look at some of these expert bodies to observe this movement. 
As the most influential expert group for EMU - with respect to central banking and financial policy - the Economic and Financial Committee (EFC) houses representatives from the national Ministries of Finance together with those from the central banks as well as other significant EU actors. Although many of its daily activities still rely on risk metrics, more and more decisions need to be made calculating the effects that individual Member States exigencies have on EU government bond markets. The secretive Eurogroup, consisting of the finance ministers of the eurozone, is another forum for the discussion of fiscal governance. ${ }^{150}$ Its informal working method is comprised of frank discussions that encompass speculations and case-by-case analyses, which supplement the formal EMU coordination instruments.

Ecofin also has an advisory body of its own, in the form of the Economic Policy Committee (EPC), which specialises in economic policy and public finance. Structured around these two pillars, the EPC is charged with developing analysis and policy consensus as it pertains to balancing national economic growth with long-term sustainability. With the Lisbon emphasis on accelerated growth and enhanced employment, the EPC has been quite active in advising Ecofin and coordinating policy initiatives. Their judgement becomes more paramount in appraising differentiated fiscal positions and in the execution of the new Pact. Whether these reforms are respected and help ensure compliance remains to be seen. Their most formidable test will be another economic downturn since the recent credit crisis has officially been deemed "highly exceptional" thereby negating the application of the SGP.

One of the attractive properties of uncertainty is the scope of creative freedom it affords these decision-makers. Unlike the rigidity of risk, which is attributed in part to its

${ }^{150}$ Uwe Puetter, The Eurogroup (New York: Manchester University Press, 2006). 
highly formal standardisation and quantitative character, government through uncertainty provides more room to manoeuvre. This proves to be a tremendous advantage when attempting to decipher what kind of fiscal framework is best suited for Europe. Contestable in nature, these methods regulate which articulation of subjectivity is validated. But because uncertainty is subjective, temporally sensitive, and conditional on individual idiosyncrasies, its exportation as a specific programme - with any systematic regularity en masse to other areas of the organisation is questionable. Of course, that is the beauty of this modality. It is not as restrictive as risk.

That being said, it does not possess an identical technocratic classification system like risk. No definite list exists. Standardised internal control measures cannot be readily designed through uncertainty. Circumstantial adaptations usually inhibit such overarching regulatory programmes. However, parallels between particular prescriptive elements, located in internal control reviews, and the modality of uncertainty may be drawn. When it comes to the other two facets of public sector management, namely operations and reputations, discernable links with uncertainty become more apparent. Interrogating these practices, we can apprehend how uncertainty penetrated EMU as a mode of management.

\section{Uncertainty Surrounding Internal Control}

By targeting domains that have traditionally resisted measurement or have become engulfed in risk management, novel regulatory programmes are constructed. These reflect the shifting governmental perceptions of the problem of managing the emerging European fiscal-monetary space through qualitative, singular futures. Uncertainty permeates these fields of operation. Its calculative practices have a programmatic ambition that resembles what we would expect to locate in various forms of risk-based technologies. Unlike risk, 
however, uncertainty is extremely more variable with continuously shifting parameters. In addition to its haphazard expositions, tracing its lineage is also complicated by the overlapping commonalities that uncertainty shares with risk. To appreciate its analytical and operational distinctiveness, relative to risk, necessitates a critical re-evaluation of some well-entrenched narratives and concepts. Doing so will suggest how uncertainty may have been appropriated in the context of EMU reform.

To begin with, the politics of financial regulation offers some insights into how uncertainty may be misconstrued as a strategy of risk. Of particular interest is banking supervision. As I alluded to above, under Basel II, Pillar 1 establishes the required capital adequacy benchmark ( 12 percent) in addition to methodologies for calculating credit and market risks. Typically classified as operational risks, they constitute part of this discursive space where the shared sentiment is that "management demands measurement." 151 For the purpose of diagnosing the history of uncertainty, however, Pillar 2 may prove more revealing. Upon closer examination, certain characteristics become visible which can also be found in the organisational infrastructure of EMU.

A new supervisory capacity is constituted to govern this space under the auspices of the second pillar. Senior management now plays an even greater role in coalescing strategic vision with organisational capacity. Monitoring mechanisms assist in this regard as they modulate economic conduct by adapting to changing market conditions. Their elasticity allows for the constant (re)assessment of current risk management processes, rendering economic affairs amenable to expert intervention. A problem, however, surfaces when singular and unique uncertain events are classified and treated as risks or when the exact nature of the problem is miscalculated. Here the entire internal control risk apparatus can

${ }^{151}$ Michael Power, Organized Uncertainty: Designing a World of Risk Management, 120. 
itself be a destabilising force if it cannot correctly identify the threat and deploy the necessary mechanisms to mitigate it.

Although this speaks to the issue of internal control, the oversight process is itself fraught with biases regarding regulatory intent, questions of good governance, and judgements about control. Discretionary conduct of this sort invites uncertainty. Of course, I am not asserting that this supervisory process is all about subjective estimations. Precautionary asset reserves exceeding the regulatory minimum act as buffers against wrong judgements and "threshold standards" for internal control exist. But, as Power notes, "Pillar 2 is a prescription for an oversight and auditing process capable of being modulated according to an assessment of the risk management process." ${ }^{.152}$ Given this critical evaluation of the risk process itself, or the control-of-control, internal control overlaps with operational uncertainty. Determinations of this kind encompass technical analysis combined with normative principles about the ultimate objective of the system. Their dialectical relationship supports this hybrid formation as uncertainty includes risk. In short, this accounts to a critical ontology of the control environment where risk management is itself problematised.

Recognising that certain risk factors may be analysed and incorporated into prudent managerial practices in order to pre-empt and prevent undue administrative errors, internal control systems may be a hazard in themselves. Since they are "organisational projections of controllability which may be displaced, such systems are only as good as the imaginations of those who designed them." ${ }^{, 153}$ Their ubiquitous character helps promote stability in some situations but it is not impervious to behavioural uncertainties. Moreover,

\footnotetext{
${ }^{152}$ Michael Power, Organized Uncertainty: Designing a World of Risk Management, 107.

${ }^{153}$ Michael Power, The Risk Management of Everything, 28.
} 
expanding the territory of risk government has become associated with the values of "good governance." Routine risk practices have the potential to amplify and entrench qualculation as the norm for organising socio-technical activity. But as the SGP crisis demonstrates, the most contentious normative decisions about legitimate and good governance are undertaken by higher echelon officials or politicians and not experts. Arguably, uncertainty is deployed within this reflexive mode of metagovernance, thus placing greater reliance on entrepreneurial foresight. At this junction, the realisation that risk management strategies are a poor substitute for governing through uncertainty becomes evident. Regulating these misfortunes and transforming them into opportunities is what the SGP reforms attempt.

\section{Operational Uncertainty}

Common to all organisations, uncertainty encompasses not only a propensity to failure based on internal and external events but also what is conventionally referred to as "business risk." Business risk may be considered a catchall category that covers losses from such factors as a drop in volumes, a shift in demand, a price squeeze, a cost surge, regulatory changes, or technological obsolescence. ${ }^{154}$ It occupies an uneasy position because of its rather nebulous character, which straddles both risk and uncertainty. Surprisingly, given Basel II's ambitious nature, this category is absent from its definition. The difficulty with incorporating further additions is that there is an inherent overlap between these categories of risk and uncertainty. Kuritzkes is correct to observe that "internal and external events can quickly bleed into business risk: in fact, the knock-on

${ }^{154}$ Andrew Kuritzkes and Hal S. Scott, "Sizing Operational Risk and the Effect of Insurance: Implications of the Basel II Capital Accord," in Capital Adequacy beyond Basel: Banking, Securities, and Insurance, ed. Hal S. Scott (New York: Oxford University Press, 2005), 263. 
effects can often be greater than the initial loss.. ${ }^{155}$ Excessive delineation may even fuel perpetual regression and spiral out of control as further divisions are categorised $a d$ infinitum. This is the curse of modernity proclaimed by Beck.

Technical risk analysis can produce quanta of economic variables assigned to, what are supposedly, operational externalities that any organisation must address and solve. What is striking about this component of risk is that it is actually devoted to regulating through uncertainty more so than risk. Often labelled as risk, it is in fact a misrepresentation of uncertainty. Just as there exist no sound measures indicating when the next Jerome Kerviel (Société Générale, 2008) will surface to exploit a system, there is no probabilistic method to predict the kind of budgetary policy flip-flopping performed by the Schröder government.

Initially stressing microeconomic supply-side reforms, Schröder abandoned the ordo-liberal orthodoxy, to considerable opposition from the Bundesbank, in favour of employment and growth strategies. ${ }^{156} \mathrm{An}$ informal agreement in 2002 prevented the issuance of an official "early warning" before the election in October of that year. Soon the “Alliance for Jobs" was quickly scrapped and replaced by "Agenda 2010" (March 2003), targeting labour-market and welfare-state reforms. Thus, politicians, as rogue traders, do not lend themselves to being readily captured as a numerical probability. Herein lies the tension between the programmatic and operational dimensions of fiscal governance. Since operational risk is actually a form of uncertainty, it is imprudent to problematise its management in terms of risk.

\footnotetext{
${ }^{155}$ Andrew Kuritzkes, "Operational Risk Capital: A Problem of Definition," The Journal of Risk Finance 4, no. 1 (2002): 47-56.

${ }^{156}$ Kenneth Dyson, "Germany: A Crisis in Leadership in the Euro Area," in The Euro at 10: Europeanization, Power, and Convergence, ed. Kenneth Dyson (New York: Oxford University Press, 2008), 150-52.
} 
As a misguided approach, the original Pact was an inadequate system that only aggravated the operational dangers facing itself. Critics contend that the SGP was overtly rigid, "forcing countries to restrain fiscal policies in difficult times and exacerbate cyclical volatility" while "inhibiting growth by limiting useful public expenditures (e.g. on investment). ${ }^{, 157}$ These culminated in the SGP crisis and exposed a deeper pool of inconsistencies that undermined the fiscal framework. From the mending and reconfiguration that ensued, operational uncertainty emerged as a major regulatory tool. Charged with compartmentalising incalculable unknowns into subgroups, in the hope of propagating new myths of controllability in EMU, it sought to reinforce what existing ones remained. Assembling an inventory of more discretionary governmental categories and technologies meant that the policy problem needed to be reformulated. The moral hazard rationale was replaced with an emphasis on the long-term sustainability of debt positions. Incredulous that opportunistic politicians could actually restrain themselves from the pervasive incentive to free-ride, the architects of EMU initially designed a "disciplinarian" framework as a solution to the collective action problem. ${ }^{158}$ But reality revealed that the apolitical nature of this regulatory regime was in fact fictitious. Heated political debates swirled around the issue of budgetary control. Ultimately, domestic politics trumped supranational dictates.

Once this rationality was revamped in alignment with uncertainty, a series of preventative and corrective innovations followed suit. Country-specific MTOs were introduced, signalling the transition to more differentiated forms of management on the

${ }^{157}$ Otmar Issing, "The Stability and Growth Pact: The Appropriate Fiscal Framework for EMU," International Economics and Economic Policy 1 (2004): 9.

${ }^{158}$ Waltraud Schelkle, "The Contentious Creation of the Regulatory State in Fiscal Surveillance," West European Politics 32, no. 4 (2009): 829-46. 
preventative side of the SGP. Not only do potential growth rates varying across borders but achieving sustainability is predicated on exploiting these unique business cycles and making appropriate adjustments in "good times." Again, a government through singular futures is better qualified to regulate the complexities and nuances of individual markets as opposed to aggregating surveillance methods, which subject EMU to an artificial uniformity that has no bearing in reality. Coupled with modifications of the corrective arm, which prioritise a broader qualitative assessment of national concerns, an assemblage of a diverse set of discursive practices emerged in which uncertainty is embedded.

\section{Reputational Uncertainty}

Automatic sanctions, argued Waigel, would help foster compliance as Member States knew that penalties were virtually a definite consequence of fiscally profligacy. Such conditions would protect the integrity of the rules-based SGP from frivolous decisions, thereby enhancing its legitimacy. However, it was Germany who eventually reneged on its promises, as it lobbied with France to hold the SGP in abeyance. Every threat of or actual violation damaged the reputation of the Pact. But these temperamental behaviours are too idiosyncratic to be captured in a probability distribution. Thus, reform was necessary to address these exigencies and it came in the modality of uncertainty.

In this regard, improved "peer pressure and support" have been identified as contributing factors in fostering compliance. Peer pressure can be thought of as "a sanction mechanism, which is designed to increase the reputational costs of political opportunism, policy reversal and policy non-implementation." ${ }^{159}$ It is widely recognised that larger Member States, in particular Germany and France, hold relatively more sway in steering

\footnotetext{
${ }^{159}$ Dermot Hodson, "Macroeconomic Co-ordination in the Euro Area: The Scope and Limits of the Open Method," Journal of European Public Policy 11, no. 2 (2004): 239.
} 
the conduct of their smaller neighbours. Yet credibility is central for effective multilateral surveillance. Simply allowing Member States to report their budgetary figures to the European Commission while simultaneously engaging in mutual surveillance procedures aimed at encouraging the "naming and shaming" of offenders into compliance has failed. ${ }^{160}$ Reputational uncertainty is now more pronounced because the political credibility of both leading Member States and the fiscal framework have been seriously jeopardised. In order to convince others to acquiesce to their demands, Member States must possess sound reputations. These intersubjective understandings are often derived from a combination of the material resources available at their disposal and the shared ideational convictions about normalcy that they subscribe to. Discursive practices help constitute the social identities that interpret the value of these ideas. Even the relevance on material capabilities is subject to modes of representation. Uncertainty is proving integral in the restoration of SGP reputations.

Surprisingly, as the political Pact suffered an egregious onslaught at the hands of its masters, the "economic" Pact retained its reputational status. ${ }^{161}$ Market confidence in the long-run sustainability of government debt obligations appears to have mitigated the risk of higher premiums. Yield spreads on government bonds did not react in any significant direction to the November 2003 crisis. Virtually identical, 10-year government bond rates were $3.72 \%$ in France, $3.71 \%$ in Germany, and $3.88 \%$ in Italy. Conversely, Spain's maintenance of a low deficit $(1.1 \%)$ went unrewarded. That kind of assurance, however, is

\footnotetext{
${ }^{160}$ Barry Eichengreen and Charles Wyplosz, "Instability Pact?" European Economic Perspectives 48 (1998): 24-40.

${ }^{161}$ Patrick Leblond, "The Political Stability and Growth Pact is Dead: Long Live the Economic Stability and Growth Pact," Journal of Common Market Studies 44, no. 5 (2006): 969-90.
} 
socially constructed and often volatile, which makes reputation potentially unmanageable through strict risk calculations.

Vulnerable to destabilising forces as its major economies seem unable to meet their budgetary obligations, the revised Pact must also manage its own reputational uncertainty. With the imminent, but speculative accession, of the new Member States from Central and Eastern Europe into the eurozone, the discussion is once again being framed in terms of risk and uncertainty. The uncertainty of when and how these new countries will adopt the euro, and the potential consequences of this transition, are only compounded by the effects of the recent credit crisis. Current members are also in a precarious situation given their deteriorated public finances. Leading countries, such as France and Germany, are not necessarily eager to expand the euro area with any great speed. The revised SGP has not yet been truly tested to determine whether it is credible and effective. But any trial should not endanger recovery efforts. At present, the economic situation remains fragile and susceptible to numerous risks and uncertainties. Successfully managing this indeterminate future is proving to be an arduous task that those responsible for implementing the rules of the SGP are now entrusted with.

What distinguishes my approach from the "uncertain society" thesis, articulated by the likes of Ericson and Doyle, is that I digress from making any ontological assertions. ${ }^{162}$ Transforming uncertainties into risks merely affirms the existence of an underlying reality that is discernable with adequate knowledge. Yet, as Ewald submits, "nothing is a risk in itself; there is no risk in reality. But on the other hand, anything can be a risk; it all depends

\footnotetext{
${ }^{162}$ Richard V. Ericson and Aaron Doyle, Uncertain Business: Risk, Insurance, and the Limits of Knowledge.
} 
on how one analyses the danger, considers the event (original italics)., ${ }^{163}$ In addition to this, I would add that nothing is an uncertainty in itself. Simply denoting uncertainty as something essentially distinct from risk loses sight of the governmental analytic. Arguing that governing through uncertainty is synonymous with governing through incalculability and therefore implausible is fallacious. It misconstrues the fact that calculation does indeed occur; just in a different qualitative form.

\subsection{Tracing Uncertainty through the Stability and Growth Pact}

Deciphering what kind of economy of power Europe is implicated in reveals not a uniform and a priori entity labelled "risk" or "uncertainty" but an historical emergence of specific discursive practices aimed that stymieing profligacy. Through the processes of signification, these produce the meanings that are attributed to various EMU categories and subjectivities; thereby recoding them along vectors of uncertainty. Accordingly, my dissertation appeals to this new arrangement that is becoming more visible in the aftermath of the 2003 Ecofin crisis. Devised to ameliorate the destabilising pressures associated with fiscal profligacy, government through uncertainty is an attempt to reconfigure the regulatory capacity of the SGP to better anticipate and respond to the unique national exigencies that produce them. It is in part through this mode of governance that EMU is rendered intelligible.

Just as risk management strategies transform this common space into a set of graphs, formulas and indexes, uncertainty is commensurate with the deployment of its own distinct calculative programmes. These socio-technical devices create new geographies of power by producing and legitimating knowledge as a non-probabilistic propensity to

\footnotetext{
${ }^{163}$ Francois Ewald, "Insurance and Risk," in The Foucault Effect, ed. Graham Burchell, Colin Gordon, and Peter Miller (Chicago: Chicago University Press, 1991), 199.
} 
vulnerability and as a register of responsibility. Through the constitution of variegated notion of normalcy, a government of economy introduces a self-regulating element to the organisation of EMU. Here Member States are conceived of as enterprising subjects convinced of the merit of prudently managing their fiscal books. Subsequently, governmental strategies are designed that reflect and shape this mentality.

How this is accomplished is revealed through an analytics of government where I diagnose the SGP reforms in an "anti-anachronistic" fashion. Genealogy rejects ascribing past narratives of risk as necessary antecedents for the present mobilisation of contingency. Each one has its own logic which is embedded in distinct EMU practices. Through the deconstructive/reconstructive ethos of the governmentality approach, we come to terms how this regulatory apparatus reflects their malleable composition with the transition to uncertainty modes of governance. The value-added of these analytical tools lies in their ability to help us recover a constellation of diverse and contested meanings of how to properly regulate this emerging spatial-temporal order which have, hereto now, been largely inaccessible via conventional approaches. In order to understand how the political economy of budgetary surveillance has transformed, it is vital to excavate the governmental terrain of the SGP to reveal how knowledge is constituted and legitimated in the production of responsible EMU subjects of government.

For this purpose, in the forthcoming chapter, I deploy these analytical tools to interrogate the specific discourses and technologies which reveal the transition in modes of governance. First, five areas for improvement are identified. These comprise the principal objectives underpinning the revisions of the Pact. Enshrined as the "political compromise" by the Brussels European Council, they reflect the dominant mentality of government and 
inform subsequent reforms. Second, the SGP is problematised through the dominant discourse of "good times," and its correspondence to "national fiscal ownership." This interpretative diagnostic provides insight into the production of EMU truths by demonstrating how a sense of ownership over the fiscal framework is deemed essential to enhancing economic performance and preventing sovereign states from ceding too much power to unaccountable supranational bodies, such as the Commission. Referring to the period when "economic activity is above potential or when growth is above trend," output stabilisation and budgetary discipline should be compatible in good times. ${ }^{164}$ Discourse is mediated by these (contested) systems of representation that account for what is legitimised as "normal good governance."

Third, the deconstructive thematic draws our attention to the preventative and corrective arms of the SGP in which these narratives are embedded. Technologies of government provoke the internalisation of self-regulation as they are inextricably bound up with "formation and transformation of truthful thought." ${ }^{165}$ By analysing how MTOs, the MTBR or the revamped EDP programme Member States in alignment with this calculative rationality, we come to understand the leverage of uncertainty through its subjectifying properties. To discern the performativity attributable to uncertainty in the constitution of this space, a careful examination of the materiality of discourse is warranted. Again, an analytics of government proves valuable in making the connection between nonquantitative, creative entrepreneurialism (thought) and the fiscal regulatory infrastructure (practice) explicit.

\footnotetext{
${ }^{164}$ European Commission: DG for Economic and Financial Affairs, European Economy: Public Finances in EMU 2006, 16.

${ }^{165}$ Nikolas Rose, Powers of Freedom, 8.
} 
Government is a problematising activity that seeks to address the issue of reasonably balancing the demands of national budgets with the precepts of a common monetary union. Although contestation abounds as to what is the best avenue to pursue, as various political factions emphasise competing interests and priorities, one general observation may be extracted. In the construction of this emerging fiscal-monetary space there is a visible tension between the programmatic and operational dimensions of EMU governance. Conceptualised as a dialectic between expertise and politics, their antagonistic relationship was amplified by the conceptual, ideological, and institutional inconsistencies implicit in the original framework, culminating in the Ecofin crisis. This (re)politicisation of fiscal relations signals an alternative approach to framing the SGP problematic by targeting the entrepreneurial capacity of self-regulating subjects at dispersed sites. 


\section{Chapter 4 "Lisbonising" the Stability and Growth Pact}

Episodes of pro-cyclical fiscal bias have been observed in the past decade with European governments cutting taxes and/or increasing expenditures, as opposed to prudently saving in case of an economic downturn. Such was the situation before the November 2003 crisis. Most countries strayed from adhering to the MTO of close-to-balance or in surplus, precipitating the eventual violation of the Pact. ${ }^{1}$ Originally acknowledged as satisfying the prudent demands of the German Bundesbank model, a pro-cyclical policy came to be viewed as fiscally counterproductive and politically inoperative. Although understandable during an economic correction, when deficit financing is politically more popular, such behaviour during "good times" merely deteriorates the fiscal position of Member States. They incur higher debt levels, which prevent them from operating within the parameters of the SGP when the economic cycle turns again.

Convergence is simultaneously impeded. This is why there is a concerted effort to promote "national fiscal ownership" emphasising expenditure issues. At least by focusing attention on the "preventative arm" of the Pact, costs may be curbed. In the short-run, this is designed to exploit the good times in order to ensure compliance with the Pact and promote stability. In the long-run, it is about sustainability. Together with the accumulation of debt is the "unnecessary amplification of GDP fluctuations," which only complicates budgetary forecasts, thereby increasing the risk of fiscal profligacy. ${ }^{2}$ In this environment, modelling of aggregate futures proves unable to account for the heterogeneity underpinning the behaviour of Member States.

\footnotetext{
${ }^{1}$ Germany first violated the three percent deficit mark in 1995, largely in part to the costs of unification. Since Jan 2006, twelve EU countries were subject to an EDP, including five EMU Member States. ${ }^{2}$ European Commission: DG for Economic and Financial Affairs, European Economy: Public Finances in EMU 2006 (Brussels: DG EcFin, 2006), 16.
} 
Whereas the programmatic dimension complements the logic of enterprise embedded within risk, it often conflicts with the operational side of fiscal affairs. The latter encompasses not only the execution of policy programmes but:

anticipates the realization of these values of enterprise with demands for accountability and transparency of due process, demands which build on cultural ideals of precision, proof, and calculability. ${ }^{3}$

Policy learning incorporates these distinct values in the construction of contingency. In Europe, this process is extremely fragmented given the diversity of national public sector and corporate cultures. Social idiosyncrasies and compulsions do lend themselves to being readily aggregated through statistical-probabilistic calculations. Agents often act on impulse and no risk management framework can entirely capture all possible contingencies. Hence, what is witnessed is a dialectic between the two competing logics of responsibility and enterprise or the programmatic and operational elements of organisational life. The Stability and Growth Pact crisis reflects this tension. In order to preserve a semblance of control, new modes of governance are required that are sensitive to the uncertainty implicit in fiscal relations within the European space as well as beyond.

Full of "discretionary clauses, inviting ad hoc, arbitrary, and discretionary interpretations," legitimisation and power in the amended SGP are increasingly in the province of more qualitative practices. ${ }^{4}$ For example, the concept of "exceptional and temporary" excess over the nominal value, but close to it, has expanded to encompass essentially any negative growth rate, including a protracted slow down compared with the

\footnotetext{
${ }^{3}$ Michael Power, Organized Uncertainty: Designing a World of Risk Management (New York: Oxford University Press, 2007), 197.

${ }^{4}$ Alan W. Cafruny and J. Magnus Ryner, Europe at Bay: In the Shadow of US Hegemony (Boulder: Lynne Rienner, 2007), 34.
} 
trend or to potential growth. ${ }^{5}$ Exceptional circumstances lend themselves to being managed through uncertainty rather than risk since probabilistic methods cannot account for their unique character. Now the Commission and Council have a greater degree of latitude in their interpretation of whether such a condition exists. The reforms are deliberately formulated to address the contingent and contextual character of fiscal relations. Economic judgement is better suited than the application of uniform rules for such a task. In short, entrepreneurial creativity plays a more pivotal role than ever before.

Of course, creative foresight is supplemented with statistical correlations rather than fuzzy dice or the reading of tea leaves; the new methodology for computing "minimum benchmarks" is one such example. However, what is crucial to grasp is the expanded role that subjective estimation plays in the preventative and dissuasive dimensions of budgetary surveillance. Greater freedom to identify, prevent and correct fiscal profligacy entails that actors utilise their critical faculties and creative skills in the mobilisation of perception according to vectors of uncertainty. Their ambition, according to one senior EU official, "is to balance the goals of fiscal austerity with the broader growth and employment objectives embodied in the Lisbon process."

Innovation facilitates competition and a renewed impetus on elasticity in governance. With this movement, Marcussen argues that a greater "emphasis is put on the provision of a framework that supports, consolidates, and coordinates interaction between autonomous change entrepreneurs in self-regulating governance networks.,7 Rather than simply submitting to monetarist prescription favouring price stability, discretionary

\footnotetext{
${ }^{5}$ Council of the EU, Improving the Implementation of the Stability and Growth Pact (Report to the European Council, 7423/05, Brussels, 2005), 14.

${ }^{6}$ Roland Eisenberg, interviewed by author, 2 May 2007.

${ }^{7}$ Martin Marcussen, "The Lisbon Process and Economic Reform," in The Euro at 10: Europeanization,

Power, and Convergence, ed. Kenneth Dyson (New York: Oxford University Press, 2008), 107.
} 
conduct appears to have (re)politicised fiscal governance. In the process, a new leverage, which anchors expertise back in human critical judgement, is rendered visible. This dialectic between expertise and politics is reconfiguring new geographies of power in EMU. Control and governmentality are at the heart of these. Nevertheless, the reconciliation of these objectives is fraught with uncertainty. As such, attempts to resolve the conceptual, ideological and institutional inconsistencies this produces must accommodate the very political dynamics at the heart of the process. Risk management alone cannot promote such reconciliation.

To re-establish some semblance of normalcy and control, abrogated by Ecofin's abeyance of the Pact's statutes, an improved governmental framework was necessary. Prosperity and accountability are "best guaranteed" by a rules-based system which reconciles the principles of long-term sustainability with stabilisation. ${ }^{8}$ Thus:

in strengthening and clarifying the Pact it is essential to secure a proper balance between the higher degree of economic judgement and policy discretion in the surveillance and co-ordination of budgetary policies and the need for keeping the rules-based framework simple, transparent and enforceable. ${ }^{9}$

Accepting this logic as the axiom upon which the new fiscal framework was to be constructed, the architects of EMU engaged in the arduous labour of reform. Ecofin's response to this new, uncertain environment came late March 2005 in the form of a European Council agreement entitled "Improving the Implementation of the Stability and Growth Pact." A new Pact and renewed hope for Europe's fiscal future had finally arrived.

\footnotetext{
${ }^{8}$ Council of the EU, Code of Conduct (Specifications on the implementation of the Stability and Growth Pact and guidelines on the format and content of stability and convergence programmes; endorsed by the ECOFIN Council on 11 October 2005).

${ }^{9}$ Council of the EU, Improving the Implementation of the Stability and Growth Pact, 3.
} 
In light of this transition, what is the regulatory capacity through which uncertainty is addressed and delivered as a mode of governance? How is uncertainty transformed from mere speculation into a modality of rule deployed in governing this emerging European fiscal-monetary space? Furthermore, what are the discursive practices that contribute to the institutionalisation of normalcy as a precondition for convergence in the construction of this novel spatial-temporal order? To answer these questions and decipher what kind of regulatory space is in fact emerging, we must apprehend how the SGP is made intelligible as a particular form of reason, aligned with perceptions of contingency, and interwoven into the political imagination and discourse of EMU. For this purpose, the deconstructive/reconstructive analytic, introduced in the preceding chapter, is of avail. These analytical tools help guide us to the contingent and heterogeneous discursive practices that are constructing the realities of EMU.

As an object of government, the revised SGP signals a different way of framing the problem of managing fiscal relations by acting on the capacity of governments as free subjects. Uncertainty is at the core of this process of restitution as it helps mediate the politics of representation around the principles embodied in the Lisbon strategy. Derived from this mentality are techniques for structuring policy questions in such a way as to mobilise the endogenous responsibility of Member States to manage their own unique variable and diverse challenges. How they are conditioned to perform such a role, in this constrained discretionary space of governance, is revealed through a genealogical excavation of the socio-technical practices of intervention that territorialise the SGP as a governmental plane. 
In this chapter, I analyse the formation of this new economy of power in Europe post-2005. First, I identify key areas for improvement that underpin the rationality of reform. It is according to these five objectives that the new fiscal framework is structured. On the basis of these, fiscal relations are subsequently problematised through the discourse of "good times," and its correspondence to "national fiscal ownership." Born into a period of good times, the SGP is temporally sensitive to cyclical conditions. Improvement stipulates effectively managing time in order to achieve favourable fiscal consolidation. Whether such adjustment efforts accelerate or are tempered is increasingly contingent on the estimated public value these policies can produce. Public Value Theory (PVT) is the broader doctrine in which this is embedded. In short, unlocking public value entails allocating budgetary expenditures to produce tangibles for public consumption in an affordable and efficient manner. Public management must be sensitive to the legitimate wishes of citizens - rather than just consumers or the corporate sector - and organise the economy so as to address those concerns. Employment and economic growth are fundamental to public value creation. A symbiotic relationship between public investment and budgetary discipline serves the interests of the Lisbon process. ${ }^{10}$ The SGP reforms complement its stated priorities.

By diagramming this discursive shift, we are better positioned to understand the (re)politicisation of the SGP in the attempt to reconcile the policy conflict resulting from an opaque underlying model, which assigns different mandates to Member States (output stabilisation) and to the ECB (price stability). This entails not only presenting the narratives but situating them in the very governmental apparatus that grants them power to condition

\footnotetext{
${ }^{10}$ Although the connection between the SGP and the Lisbon Agenda is noted, any evaluation of its success is outside the scope of this dissertation.
} 
fiscal conduct. Concrete political processes are often neglected in favour of metatheoretical discussions positing how language is active in the constitution of social relations rather than simply reflecting a pre-existing world. Without embedding discourse, Jef Huysmans contends, "these approaches mask the technical nature of the implementation process and its constitutive importance." ${ }^{11}$ Power is relegated to an independent ideological realm and the reading becomes susceptible to the charge of idealism. But emplotment is the technological expression which historicises and reproduces narratives thereby affording them their "own density and vitality."12

Thus, I turn to the "preventative" and "corrective" practices which contextualise the discursive shift towards uncertainty. Technologies of government, such as country-specific MTOs, demonstrate the application of non-quantitative knowledge in the arrangement of EMU relations. Together with the enhanced complementarity between the SGP and national fiscal rules and institutions, fostered by the MTBR, the precautionary character of economic governance is synoptic of uncertain modes of regulation. Add the revamped "corrective" EDP to fiscal surveillance and uncertainty, as an enterprising potential, is being mobilised as a pragmatic response to an indeterminate future. This assemblage produces temporary stabilisations which may induce the internalisation of self-regulation. What practices render this new managerial disposition real and what forms of power circulate in these processes of subjectification is revealed by interrogating their points of resonance wherever they may be generated. We will then better understand not only the reforms engendered by the 2003 SGP crisis but the adoption of a new mode of governance.

\footnotetext{
${ }^{11}$ Jef Huysmans, The Politics of Insecurity: Fear, Migration and Asylum in the EU (New York: Routledge, 2006), 92.

${ }^{12}$ Nikolas Rose, "Governing by Numbers: Figuring out Democracy," Accounting, Organizations and Society 16, no. 7 (1991): 676.
} 


\subsection{Amending the Rationality of the Pact}

Amid a barrage of criticisms, delinquent governments (i.e. Germany and France) did not shoulder the burden of reform once the Pact imploded in the autumn of 2003. In fact, no Member State did or would for that matter. Ill-conceived macroeconomic policy was to blame for what was arguably one of the most formidable crises to paralyse the EU. ${ }^{13}$ "Death knells" were sounding but the architects of EMU managed to salvage a new fiscal framework. ${ }^{14}$ From the ashes, a phoenix did not rise; thus, hopefully obviating the reproduction of its original brief tenure. Rather, renewal came in the form of "'sea change' towards 'Lisbonization' of governance in which the Lisbon strategy came to act as the umbrella for...macroeconomic policies." ${ }^{15}$ No longer were national politics to play a subservient role to abstract principles favouring autonomous institutions, such as the ECB. The balance between fiscal stabilisation and debt sustainability (i.e. growth) appeared to tilt toward the latter. Although the two nominal anchors -3 percent to GDP deficit ratio and 60 percent to GDP debt level - were retained within a rules-based system, the Pact became explicitly much more discretionary.

With unaltered incentives for compliance, however, some contend that the SGP has lost its "teeth" to become an impotent tool for fiscal consolidation. ${ }^{16}$ Arestis and Sawyer echo this sentiment. In their opinion, "the death of the SGP is probably a better description

\footnotetext{
${ }^{13}$ Barry Eichengreen and Charles Wyplosz, "Instability Pact?" European Economic Perspectives 48 (1998): 24-40.

${ }^{14}$ Iain Begg and Waltraud Schelkle, "The Pact is Dead: Long Live the Pact," National Economic Institute 189 (2004): 86.

${ }^{15}$ Gaby Umbach and Wolfgang Wessels, "The Changing European Context of Economic and Monetary Union: 'Deepening', 'Widening', and Stability,' in The Euro at 10: Europeanization, Power, and Convergence, ed. Kenneth Dyson (New York: Oxford University Press, 2008), 64.

${ }^{16}$ Bernard Winkler, "Stability and Growth: The Role of Monetary Policy and Other Policy Actors in EMU," in EMU Rules: The Political and Economic Consequences of European Monetary Integration, ed. Francisco Torres, Amy Verdun and Hubert Zimmermann (Baden-Baden: Nomos, 2006), 176.
} 
of...the revamped SGP in March 2005." ${ }^{\prime 17}$ Rigid rules may have been supplanted by elastic assessments but at what cost? Less transparent and more complicated than the original framework, contestation and uncertainty abound whether the SGP can in fact garner the necessary political commitment upon which its success hinges. Each national government faces unique circumstances that are fluid and contingent on their respective political economies. To convince them of the merits of compliance, and thus convergence, the SGP problematic must be reframed in a way that speaks to their individual concerns. Through the deconstructive/reconstructive ethic, we can begin to understand how the underlying rationality of fiscal governance is changing to accommodate this diversity of demands.

To reduce the downside risks facing the SGP, officials needed to tackle the problem of reconciling the dualism of national fiscal sovereignty and policy convergence. Excessive room to manoeuvre would strip that Pact of its "bite" and essentially render the framework redundant. Irrespective of its anti-growth bias and pro-cyclical nature, the SGP has been effective in diminishing deficits and disciplining national budgets. From an average deficit of -5.1 percent of GDP in the first half of 1990 s to -2.1 percent in the latter half, the euro area witnessed an even further decline between 2000-2008, posting an average deficit of only - 1.8 percent of GDP. ${ }^{18}$ Overall, the fiscal rules have had a disciplinary effect, marking a 2.5 percent permanent improvement in balanced budgets for the euro area since the early 1990s. ${ }^{19}$ Evidence in support of this "stability culture" was convincing enough to justify the

\footnotetext{
${ }^{17}$ Philip Arestis and Malcolm Sawyer, "Macroeconomic Policy and the European Constitution," in Alternative Perspectives on Economic Policies in the European Union, ed. Philip Arestis and Malcolm Sawyer (New York: Palgrave MacMillan, 2006), 20.

${ }^{18}$ Eurostat, "General government deficit (-) and surplus (+); Percentage of GDP," (2009); available from http://epp.eurostat.ec.europa.eu/tgm/table.do?tab=table\&init=1 \&plugin=1\&language=en\&pcode=teina200 ${ }^{19}$ Eckhard Hein and Achim Truger, "Fiscal Policy and Macroeconomic Performance in the Euro Area: Lesson for the Future," in Euroland and the World Economy: Global Player or Global Drag? ed. Jorg Bibow and Andrea Terzi (New York: Palgrave MacMillan, 2007), 157.
} 
Pact's prolonged existence. Now all that was necessary was to amend its logic and components in order to address the uncertainty implicit in fiscal relations.

For this purpose five areas of improvement were identified by Ecofin and entrenched in the "political compromise," which the European Council formally sanctioned in its Presidency Conclusions on the 22 and 23 of March 2005. ${ }^{20}$ Most of the technical issues were deliberated by the Economic and Financial Committee, who is the expert authority for EMU affairs. Its mandate comprises the evaluation of the economic and financial activity of both Member States and supranational institutions. This supervisory capacity is akin to internal control. These senior technocrats review and prepare the administrative and political agendas for the Eurogroup, the Commission, and the Council. Not only does this make the EFC a "microcosm of the big world of discussions among ministers" but "a natural interface between the formal and informal governance processes. ${ }^{, 21}$ Its work continued well after the Council endorsed the reforms in March 2005 as it laid the legal and logistical foundations for the new system.

Virtually all the technical material, including the compilation of the "other relevant factors" devised to relax the EDP, was debated and resolved in this forum. ${ }^{22}$ Not surprisingly, specifying which conditions would exempt deficits in excess over the reference value of 3 percent from Community reprimand proved controversial even within the EFC. The list that was finally adopted exhibits this temporal contingency reflective of government through uncertainty. Only those breaches that the Council considers are

\footnotetext{
${ }^{20}$ Council of the EU, Brussels Spring European Council: Presidency Conclusions, 22 and 23 March 2005,7619/1/05, REV 1, CONCL 1, (Brussels, 2005).

${ }^{21}$ Uwe Puetter, The Eurogroup (New York: Manchester University Press, 2006), 73.

${ }^{22}$ Martin Heipertz and Amy Verdun, "The Dog That Would Bark But Never Bite? Origins, Crisis and Reform of Europe's Stability and Growth Pact," in EMU Rules: The Political and Economic Consequences of European Monetary Integration, ed. Francisco Torres, Amy Verdun and Hubert Zimmermann (Baden-Baden: Nomos, 2006), 124.
} 
temporary may qualify for this exemption. But the EFC defined "temporary" in a rather vague fashion, primarily denoting the end of a market correction. Since this varies across economies, time is no longer imagined as uniformly linear but is recoded in relation to how contingency is constructed in a particular context. Temporality is reimagined with each potential violation of the statutes. For the new Pact to be effective, our sense of time must be reconceptualised in relation to specific sites. Either accelerating or decelerating, depending on how uncertainty is mobilised to help regulate the fiscal problematic in question, the velocity of time is increasingly a factor in demarcating appropriate budgetary conduct. Certain states will recover faster than others. But whether they satisfy the criteria for exemption is ultimately up to the discretion of the Council. Experts do not decide the outcome but politicians do. Coupled with the stipulation that the ratio must remain close to the nominal value, the new SGP rationality recognises the necessity to identify and manage volatile stabilisations that fail to permanently reproduce themselves at regular intervals.

While the EFC deliberated most of the administrative issues, certain points of contention were left for Ecofin to resolve. As such, its Economic Policy Committee became the principal expert body that sought to coordinate potential structural reforms in alignment with the employment and social impetus of the Lisbon strategy. More substantive debates about the direction and scope of the reform process occurred here because of the EPC's "emphasis on policy reflection exercises, economic analysis and policy advice as regards more fundamental challenges." 23 Some of the topics raised concerned the long-term sustainability of public finances and economic implications for labour markets. Given the variability and diversity surrounding these issues, the EPC proposed framing them in the

\footnotetext{
${ }^{23}$ Uwe Puetter, "Providing Venues for Contestation: The Role of Expert Committees and Informal Dialogue Among Ministers in European Economic Policy Coordination," Comparative European Politics 5, no. 1 (2007): 27.
} 
context of the BEPGs. Albeit non-binding, there is a movement towards accommodating different economic strategies under a common framework.

Together these expert bodies produced the following recommendations where improvement was deemed necessary:

1) enhance the economic rationale of the budgetary rules to improve their credibility and ownership;

2) improve "ownership" by national policy makers;

3) use more effectively periods when economies are growing above trend for budgetary consolidation in order to avoid pro-cyclical policies;

4) take better account in Council recommendations of periods when economies are growing below trend;

5) give sufficient attention in the surveillance of budgetary positions to debt and sustainability. ${ }^{24}$

From these statements, one may extrapolate the individualising tone underscoring the mentality of reform. In addition to improving its economic logic, by increasing the focus on debt sustainability, greater emphasis is placed on current national developments which were previously muted.

The ambition is to restore the legitimacy of the SGP framework while respecting the fiscal sovereignty of Member States. Inventing appropriate forms of government to adequately fulfill this objective is a daunting task; one compounded by its initial failure. We are reminded that the SGP is not an autonomous entity but intimately interconnected with various other projects in complex dialectical relationships. "Deepening" and "widening" entails being embedded in a constellation of assemblages each with their own unique systems of power. ${ }^{25}$ For instance, Broad Economic Policy Guidelines are highly credited by finance ministries and Community departments alike for structuring an

\footnotetext{
${ }^{24}$ Council of the EU, Brussels Spring European Council: Presidency Conclusions, 22 and 23 March 2005. ${ }^{25}$ Wolfgang Wessels and Thomas Traguth, "Opportunity or Overstretch? The Unexpected Dynamics of Deepening and Widening," in Crises in European Integration. Challenges and Responses, 1945-2005, ed. Ludger Kühnhardt (Oxford: Berghahn Books, 2008), 79-94.
} 
environment conducive to the development of an overarching strategy. ${ }^{26}$ In the form of a Council recommendation, Member States are invited to incorporate these Treaty-based instruments for economic policy coordination into their National Reform Programmes (NRP). Dyson credits these BEPGs for creating stability, "in which the policy lessons entrenched in the institutions have been internalized to the point where they form part of the policy mainstream."27 Arguably, this is helping promote forms of self-regulation as it aligns individual state agendas in conjunction with broader Community ambitions.

In a similar vein as the revised Pact, the 2005-2008 collection of BEPGs omitted to stipulate country-specific provisions. Rather:

in order to foster ownership and legitimacy at national level, it was considered that the guidelines should leave Member States the room to develop the appropriate policy mixes to cater for their own national specificities. ${ }^{28}$

The Lisbon process merely reinforces this malleable mode of multilateral surveillance, allowing it to reflect the changing problem of government as a strategic response through uncertainty. Together they are implicated in relationships with projects such as the euro and the Single Market. The subsequent entrenchment of these principles in European institutions endows them with longevity and power over national economic policy. ${ }^{29}$ Eventually, the sedimentation of this institutional infrastructure comprises notions of normalcy, which are further propagated through diverse technologies of government.

A word of caution is in order about treating the government through uncertainty and its individualising propensities as being synonymous with complete autonomy. Neither

\footnotetext{
${ }^{26}$ Jean-Paul Fitoussi and Jacques Le Cacheux, Report on the State of the European Union, Volume 2: Reforming the European Union (New York: Palgrave MacMillan, 2007), 3.

${ }^{27}$ Shawn Donnelly, "Explaining EMU reform," Journal of Common Market Studies 43, no. 5 (2005): 949.

${ }^{28}$ European Commission: DG for Economic and Financial Affairs, European Economy: Broad Economic Policy Guidelines (for the 2005-08 period) (Brussels: DG EcFin, 2005), 9.

${ }^{29}$ Kenneth Dyson, The Politics of the Euro-Zone (New York: Oxford University Press, 2000).
} 
discourses nor subjects are independent of their realities but immersed and coterminous. They possess a historicity and a materiality that binds them to a particular context. This embeddedness questions the frequent fragmentation of politics and administration located in much of the literature. As the 2003 Ecofin crisis revealed, this rigid separation between expertise and politics, in deciding the best policy, is ostensibly artificial.

The interpenetration and embeddedness of diverse discursive practices privileging public value creation are facilitating a renewed political dialogue. The result is the renegotiation of core EMU definitions and policy objectives. As opposed to obscuring the role of "peer support" and "peer pressure" or the visibility of the Commission, the 2005 reforms acknowledge the inadequacy of key quantitative indicators while reaffirming the significance of these multilateral forms of surveillance and discretionary governance. ${ }^{30}$ Of course, whether granting the Commission the right to issue an "early policy advice" will be effective is yet to be determined. Nevertheless, a reconstructive analytic alerts us to the reformulated rationalities underpinning the new SGP as it points to how the principles embodied in the Lisbon strategy inform the new direction of SGP reform. To gain a better appreciation of this transition, I analyse one of its most salient narratives.

\section{Taking Stock of "Good Times"}

Often policy-making is afflicted with uncertainty because of political fiat. If it cannot simply be eliminated through technocratic fiat, then, according to Lohmann, it is prudent to attempt to mitigate these "foreseeable unforeseen contingencies" consequential of fiscal

\footnotetext{
${ }^{30}$ Council of the EU, Brussels Spring European Council: Presidency Conclusions, 22 and 23 March 2005, 24-27.
} 
relations. ${ }^{31}$ Unfortunately, these challenges do not emanate from one identifiable centre, such the nation-state, but are rather the product of diverse "articulatory practices" operating in unique spatial-temporal configurations. ${ }^{32}$ Together they form the "discursive relations" that characterise the political economy of EMU. Uncertainty, as a governmental construct, helps capture the variability and contestability implicit in these diverse relations as it directs our attention to the very terrain where these discursive practices are rendered real through processes of politicisation.

More significantly, a genealogical analysis demonstrates how these "hot" situations, such as the SGP crisis, are pre-empting the contestation of previously immune calculative technologies and opening up new spaces for rethinking how they are deployed within EMU..$^{33}$ The effect is the exposure of what were once rigid "enclosures," accessible only to specialised networks of experts. Increasingly, these governmental domains are becoming susceptible to competing political interests vying to frame the debate and enact specific policies on their terms. With the 2005 reforms, these terms parallel the objectives embodied in the Lisbon strategy; each with its own unique national character. As this dialectic between politics and expertise unfolds, a discursive shift is observable which contrasts with the monetarist orientation of the original Pact that immunised expertise from political interference. In this process, language is appropriated in different ways in the production of meaning and knowledge of the SGP problematic.

\footnotetext{
${ }^{31}$ Susanne Lohmann, "Sollbruchstelle: Deep Uncertainty and the Design of Monetary Institutions," International Finance 16, no. 1 (2000): 95-110.

${ }^{32}$ Ernesto Laclau and Chantal Mouffe, Hegemony and Socialist Strategy: Towards a Radical Democratic Politics (London: Verso, 1985).

${ }^{33}$ Andrew Barry and Don Slater, "Introduction," in The Technology Economy, ed. Andrew Barry and Don Slater (New York: Routledge, 2005), 11.
} 
An analysis of the "nodal points," through which meaning is inscribed and represented, demonstrates how uncertainty enters EMU discourse to redefine the operative field of budgetary relations in Lisbon's promotion of "job creation, structural reforms, and social cohesion." ${ }^{34}$ Its strategic codification, conceptualised as this relationship between competing forces, is fixed by the governmental technologies that I dissect. New geographies of power are constructed to accommodate this spatial reconfiguration of European economic governance. Expressed as government-at-a-distance, "it is only to the extent that such alignments of diverse forces can be established that calculated action upon conduct across space and time can occur at all., ${ }^{35}$ As EMU moves to regulate dispersed "publics" (governments) at diverse sites of potential deviation, control is exercised in their articulation and fixation as objects of government. By targeting the future disposition of EMU objects through the discourse of "good times," the governmental modality of uncertainty exerts control over fiscal relations through their presence in time. Efforts to internalise notions of self-regulation, within this regulatory time-space, strive to align austerity measures with national interests. But whereas risk management aims to plot these at regular intervals, forecasting their incidence, the best that can happen is the production of temporary stabilisations which hopefully correspond to said alignment.

Monitoring of the accidental is itself a temporal exercise as the revamped Pact attempts to re-establish control over subjects in regards to both their present and future positions. The uncertainty of fiscal conduct disjoins and accelerates, thus inhibiting the guarantee of a universal permanence. Uni-linear readings of time neglect this temporal flux

\footnotetext{
${ }^{34}$ Council of the EU, Improving the Implementation of the Stability and Growth Pact, 2.

${ }^{35}$ Nikolas Rose, "Governing 'Advanced' Liberal Democracies," in Foucault and Political Reason: Liberalism, Neo-liberalism and Rationalities of Government, ed. Andrew Barry, Thomas Osborne, and Nikolas Rose (Chicago: The University of Chicago Press, 1996), 43.
} 
and its ramifications for regulatory design. Nevertheless, we can diagram how fiscal profligacy is problematised as an abnormality through the discourses of "good times" and "national fiscal ownership." The mobilisation of contingency is at the heart of this process. Once cognisant of how it captures the political imagination of Europe, our attention is directed to the governmental apparatus that is devised as its solution. To this effect, power operates through discursive practices to produce temporary stabilisations which reaffirm some semblance of control over what are perceived as uncertain fiscal relations.

In tatters itself, the Lisbon agenda's future is intimately intertwined with the success of the revamped SGP. Not only is it redefining the problem of fiscal governance by charting a new mandate, but by (re)politicising the process, it infuses further uncertainty as it unleashes the unsuspecting forces of politics. How this tandem is stabilised and what synergies it produces depends on its capacity to evoke compliance. That demands a renegotiation of economic governance which strikes to balance debt sustainability, and the growth it spurs, with macroeconomic stabilisation. A tensional relationship, the hope is that it may find some resolution in the promotion of national fiscal ownership. For that to be successful, the SGP needs to be receptive to policy learning and flexible execution in this constrained space.

Discretionary modes of governance hold promise as they disturb the "monotopic" vision of Europe as a uniform, common space susceptible to a pre-given "narrative of cohesion. ${ }^{37}$ A more convincing depiction conceives of multiple, contested discourses that strive to control how EMU is ordered through the representation of the SGP as a particular problem of government. It is argued here that uncertainty is gaining traction as a boundary

\footnotetext{
${ }^{36}$ Ole B. Jensen, and Tim Richardson, Making European Space: Mobility, Power and Territorial Identity (London: Routledge, 2003).

${ }^{37}$ Chris Rumford, Cosmopolitan Spaces: Europe, Globalization, Theory (New York: Routledge, 2008), 23.
} 
object framing the conditional parameters, which can accommodate fiscal sovereignty together with Community ambitions, through the use of time. It does so in the attempt to optimise fiscal conduct through two primary narratives.

The two fundamental discourses, whose resonance has been amplified in the aftermath of the Ecofin crisis, are those of "good times" and its relationship to that of "national fiscal ownership." These reflect the prevailing rationality of government. In order to re-establish the myths of control, upon which any organisational infrastructure depends, European leaders recognise the necessity of making adjustment efforts to complement the cyclical conditions facing individual Member States. Enhanced cyclicality and policy reform complementarity (liberalisation of labour and product markets) facilitate the materialisation of synergies between the EU regulatory regime and national jurisdictions. Their coincidental embeddedness in the same fiscal-monetary space demands a certain level of managerial correspondence and mutual policy coherence as a prerequisite for convergence. Fiscal rules are only as good as how effective they prove to be in safeguarding the sustainability of public finances. But, according to Buti, Eijffinger and Franco, in order to achieve this objective they must fulfill several criteria, one of which is the "flexibility" that allows "judgment to accommodate unforeseen circumstances." 38 In a vastly heterogeneous budgetary constellation, such as EMU, flexibility is a prerequisite for effective complementarity. Without the capacity to tailor context-specific policies, it is difficult to take advantage of asynchronous market upswings in order to make larger structural adjustments in good times.

\footnotetext{
${ }^{38}$ Marco Buti, Sylvester Eijffinger, and Daniele Franco, "Revisiting the Stability and Growth Pact: Grand Design or Internal Adjustment?” CEPR Discussion Papers 3692 (2003).
} 
"Spend it while you have it" is a common maxim, but maximising the utility of individual nations, under the SGP statutes, leads to Pareto-inferior equilibria. ${ }^{39}$ To avoid the mistakes of the past, and potentially a conflictual scenario where interpretations digress leading to another bout of institutional paralysis, it is crucial for governments to pursue preventative consolidation programmes when economic times are more favourable. Member States:

should achieve a more symmetrical approach to fiscal policy over the cycle through enhanced budgetary discipline in periods of economic recovery... thus creating the necessary room to accommodate economic downturns and reduce government debt at a satisfactory pace. ${ }^{40}$

These good times are "identified as periods where output exceeds its potential level, taking into account tax elasticities." ${ }^{41}$ Output stabilisation and fiscal discipline complement one another during these periods as available revenue permits counter-cyclical improvement to buttress the books. Subsequently, it cushions the severity of a recessionary contraction thereby creating the necessary scope so that automatic stabilisers, not to mention the common monetary policy, can work. Room to breathe also prevents profligate governments from "crowding out" private investment financing. In turn, access to capital prolongs economic good times.

What is striking is that empirical evidence supports the converse of this mentality across Europe in the years leading up to the Ecofin crisis. ${ }^{42}$ Rather than pursuing a prudent budgetary approach and consolidating their finances in periods of good time, Member States demonstrated their disregard for the business cycle by increasing expenditures and

\footnotetext{
${ }^{39}$ Frank Knight, Risk, Uncertainty and Profit (New York: A.M. Kelley, 1921/1964).

${ }^{40}$ Council of the EU, Code of Conduct, 5.

${ }^{41}$ Council of the EU, Brussels Spring European Council: Presidency Conclusions, 22 and 23 March 2005, 30.

${ }^{42}$ European Commission: DG for Economic and Financial Affairs, European Economy: Public Finances in EMU 2006 (Brussels: DG EcFin, 2006), 16.
} 
reducing taxes. Beholden to social groups and a working class, that opposed the gradual ascendance of neoliberalisation and subsequent welfare retrenchment, France refused to comply with the Commission's request of an additional 0.4 percent reduction - on top of measures already included in the 2003 budget - to finance its tax cuts. Overoptimistic forecasting only compounded the problem. ${ }^{43}$ Ill prepared to weather the headwinds that would batter Europe during the 2001 recession, governments had little choice but to breach their commitments under the SGP.

Conversely, there is the contentious line of argumentation which posits that procyclical tendencies are engendered by the imposition of a ceiling on deficits. In fact, this may even counteract:

the free play of automatic stabilisers...(and) provokes governments to choose budgetary restrictions that weigh more heavily on categories of public expenditure that most favour potential growth, such as research and development expenditure, infrastructure investment, etc... ${ }^{44}$

Neither does this approach promote national policy coordination. Nevertheless, properly identifying good times, in order to accommodate efforts at managing unique contingencies, has become a priority.

Favourable cyclical conditions (neglected in favour of "total" deficits in the original SGP) must be exploited to bolster sustainable fiscal positions. With the 2005 reforms, less emphasis is being placed on deficits, which fluctuate quite readily, and increasingly on debt levels, which remain more constant over the same period of time. Sixty percent may appear as a low threshold but it only pertains to "explicit" government debt. "Implicit" debt, which concerns expenses related to statutory commitments, is omitted from the calculations.

\footnotetext{
${ }^{43}$ Martin Heipertz and Amy Verdun, "The Dog That Would Bark but Never Bite? Origins, Crisis and Reform of Europe's Stability and Growth Pact," Journal of European Public Policy 11, no. 5 (2004): 131.

44 Jean-Paul Fitoussi and Jacques Le Cacheux, Report on the State of the European Union, Volume 2:

Reforming the European Union, 27.
} 
Explicit debt alone, however, is projected to balloon from about 70 percent today to almost 200 percent by $2050 .^{45}$ Add the impending expenditure increase resulting from an ageing population (i.e. pension reforms) and heterogeneous governments must incorporate qualitative elements on top of quantitative ones in order to confront their unique demographic challenges. Incomes from input factors vary as do saving rates because of demographic, institutional, and socio-economic differences between nations.

Macrobudgetary policy design must cope with these structural effects in its attempts to safeguard the long-term sustainability of public finances. Such broader implicit liabilities represent numerous potential uncertainties rather than uniform risks. Faced with these challenges, the consensus is that Member States should "take active steps to reach the MTO and make larger structural efforts in good times."46 More "ambitious" strides are ostensibly lauded. A troubling corollary, however, is that negative output gaps are more visible in economic forecasts, announcing more "bad" times than "good." A negative output gap bias is damaging to the integrity of the fiscal framework. Jose Manuel Ganzalez-Paramo, of the European Central Bank, reminds us that their "predominance in the ex ante assessment of countries' economic positions...could lead to persistent shortfalls in consolidation efforts." ${ }^{47}$ He echoes a sentiment shared by his ECB Executive Board colleagues. Rigid rules may be an anachronistic fixture of Europe's fiscal regime but the introduction of discretionary provisions has come at a cost. Opportunistic politicians will be tempted to exploit this bias by framing their budgetary position in such a manner that grants their

\footnotetext{
${ }^{45}$ European Commission, Quarterly Report, 5, no. 4 (2006).

${ }^{46}$ European Commission: DG for Economic and Financial Affairs, European Economy: Public Finances in EMU 2006, 91.

${ }^{47}$ Jose Manuel Ganzalez-Paramo, "The Reform of the Stability and Growth Pact: An Assessment" (Speech at the Conference on "New Perspectives on Fiscal Sustainability," Frankfurt, Germany, October, 13, 2005).
} 
economies greater allowances to spend while avoiding politically uncomfortable austerity measures.

Prior to EMU, pro-cyclicality was primarily common during bad times. That, however, has changed with the advent of the monetary union as the incidence of budgetary corrections increasingly shifted to periods of expanding output. Much of this is attributed to expenditure propensities, which are observed to increase disproportionately faster when a positive output gap is identifiable. The Commission suspects "identification and implementation lags" to be responsible for such behaviour; together with "strong pressures to spend budgetary windfalls accruing in good times." ${ }^{48}$ Arguably, these factors are related as a government's inability to properly account for its position in the business cycle makes it vulnerable to the externalities of an incorrect assessment. This is especially problematic since budgetary surveillance is plagued by persistent errors in measuring the cycle in realtime. Uncertainty, as Schelkle notes, can adversely affect compliance because:

even if the Treasury has a strong prerogative and central government is largely in control of the budget, it may still be difficult to determine with any precision where the economy is in the business cycle in time to adjust the fiscal stance appropriately. Different methods of estimating structural deficits produce notoriously different results. This implies that governments may inadvertently engage in pro-cyclical policy while intending to act counter-cyclically. ${ }^{49}$

Coupled with the poor appraisal of potential revenue generating tax income and the challenges facing finance ministries are only exacerbated. ${ }^{50}$ Thus, if Europe is to avail from the reformed Pact, good times need to be accurately identified as a precursor for fiscal consolidation.

\footnotetext{
${ }^{48}$ European Commission: DG for Economic and Financial Affairs, European Economy: Public Finances in EMU 2006, 16.

${ }^{49}$ Waltraud Schelkle, "The Theory and Practice of Economic Governance in EMU Revisited: What Have We Learned About Commitment and Credibility?" Journal of Common Market Studies 44, no. 4 (2006): 676.

${ }^{50}$ European Commission: DG for Economic and Financial Affairs, European Economy: Public Finances in EMU 2007, 4.
} 
Already advances are evident as the revised rationale underlying the 2005 reforms acknowledges that the risk management of short-term budgetary fluctuations is futile, if not impossible, to execute effectively. Good planning, which promotes discipline-oriented policies, should instead focus on debt and the long-term sustainability of public finances. However, Coeure and Pisani-Ferry question whether this will be sufficient. In its remodelled form, the SGP lacks the necessary "intellectual foundations of a renewed system of governance" and it fails to address "the issue of enforcement," which may precipitate the "risk of undisciplined case-by-case decisions guided by political pressure and horse-trading." ${ }^{51}$ But such "political compromises" often come at the expense of the fair and equal treatment of Member States. Asymmetry of this kind was the trigger for this entire crisis to begin with. Accordingly, the Council reaffirmed equality as a fundamental pillar behind the fiscal framework. ${ }^{52}$ Furthermore, at a national level, lax enforcement may contribute to the pro-cyclical bias of macroeconomic policy referred to above.

Long-term sustainability, however, is not simply a measure of budgetary performance. There is a strong socio-political component to it as well. For example, France pressed for more flexibility because its vision of managed globalisation, or mondialisation maitrisee, is characterised by such a long-term horizon. It conforms to monetarist integration as a way for remaining a relevant player and capable of intervening when the appropriate time arises to promote its social purposes. Delors observes that:

historically there has always been a minority position in France that views inflation as the most damaging for the long-term health of the economy: undermining the value of the currency, tempting capital to flee, and hurting

${ }^{51}$ Benoit Coeure and Jean Pisani-Ferry, "Fiscal Policy in EMU: Towards a Sustainability and Growth Pact," Oxford Review of Economic Policy 21, no. 4 (2005): 609.

${ }^{52}$ Council of the EU, Brussels Spring European Council: Presidency Conclusions, 22 and 23 March 2005, 3. 
the poor and middle classes...This minority has always sought to modernize France: to stabilize the currency, to fight inflation, and to promote healthy growth and employment. ${ }^{53}$

Fortuitously, this minority has seized political office and power in a variety of roles: Delors at the Commission, Camadessus at the IMF. The problem with such an approach is that the "promise of a 'social Europe' remains forever absent and affirms its opposite." sedimentation of liberal practices entrench a resistance against potential good times as understood by the French.

By "hesitantly" acquiescing to a monetarist strategy, France has been hurt by the appreciating euro. This was the case in the early parts of the decade as it is today. In addition to a projected budget deficit of 8.2 percent in the 2009 fiscal calendar, France's trade deficit has ballooned to US $\$ 55.6$ billion as a result of an uncertain demand outlook and the underutilisation of production capacities. Of course, there are neighbouring laggards that are much worse-off: take Spain, Greece or Latvia for example. In the most recent European Economic Forecasts (Autumn 2009), Macro Buti, Director General of Economic and Financial Affairs, believes that uncertainty remains high though risks are balancing. Forecasts in this fragile recovery are complicated by not knowing whether impaired credit channels will open sufficiently to spur economic growth. ${ }^{55}$ Good times are still far away.

\footnotetext{
${ }^{53}$ Rawi Abdelal, "Writing the Rule of Global Finance: France, Europe, and Capital Liberalization," Review of International Political Economy 13, no. 1 (2006): 7.

${ }^{54}$ Alan W. Cafruny and J. Magnus Ryner, "Is the SGP Crisis Also the Crisis of the EU? Assessing the EMU from a Structural, Transatlantic Perspective," in Between Growth and Stability: The Demise and Reform of the European Union's Stability and Growth Pact, ed. Lea Simona Talani and Bernard Casey (Edward Elgar: Northampton, MA, 2008), 75.

${ }_{55}^{5}$ European Commission: DG for Economic and Financial Affairs, European Economic Forecasts- Autumn 2009 (DG EcFin, 2009); available from http://ec.europa.eu/economy_finance/publications/publication1 6055_en.pdf.
} 
Arguably, these are highly expectational circumstances that we are experiencing, which have not been witnessed for more than a generation. But even the credit crisis produced asynchronous shocks that are impacting each European economy differently. Property bubbles that burst in Spain and Ireland were undetectable in Germany or the Netherlands. Through this narrative of good times, national governments can devise what they consider as the appropriate strategies to generate politico-economic gains in a manner not previously available to them. It embodies the vision of European governments as masters over the creation of public value by granting credence to the notion that their longterm economic sustainability and propensity is inexorably intertwined with a myriad of temporally distinct political agendas and social values. Rather than stipulating conformity to abstract risk modelling, which is devoid of any actual contextuality or historicity, the Lisbonisation of budgetary governance recognises that decoupling the political economy of each Member State from its own management of time is futile. Furthermore, a disregard for how time is appropriated is antithetical to fostering any sense of national fiscal ownership. As the example of France demonstrates, how governments organise their fiscal affairs is very much indicative of how they understand time and deploy it as a construct in reconciling their domestic interests with their international obligations. By making allowance for variegated representations of time, the revamped SGP signals an enhanced degree of control in the face of uncertainty.

Europe's experience with subordinating fiscal to monetary policy, with little reservation, proved disastrous in its effort at mediating the monetarist driven liberalisation of markets and removal of barriers with Europe's social model. Fears that a "race to the bottom" would undermine social protection, as the capacity of governments to enact 
redistributive programmes diminished, provoked a backlash against globalising forces. Culminating in the 2003 Ecofin crisis, the subsequent reforms this engendered are an attempt to accommodate the competing monetarist and European social model discourses within one framework.

An excavation of this emerging governmental territory through the reconstructive analytic reveals how the narrative of good times articulates this reabsorption of the technocratic sphere into the political as a particular response to the identification and rationalisation of this problem of fiscal relations in terms of public value creation. Expertise becomes lodged in political practices of uncertainty designed to curb profligacy in ways that foster the growth and employment envisioned by the Lisbon agenda. As this happens, macroeconomic management comes to increasingly rely on subjective critical assessments of key figures, such as Schröder, which are too idiosyncratic to capture in a normal distribution curve. More room to manoeuvre affords national leaders and their officials the latitude necessary as they adjust to a changing political economy and seek to reconcile domestic and Community ambitions. In this "discontinuous and contingent reterritorialization of the economic," the exploitation of favourable market conditions, or good times, is pivotal for the success of this relationship. ${ }^{56}$

Good times advocate the more prudent approach of budgetary consolidation in light of the looming disruptions plaguing cooperative fiscal relations in EMU. Because the challenges facing Member States are not uniform or probabilistically consistent, favourable conditions need to be exploited in a counter-cyclical fashion to ensure an adequate cushion during a market correction is available. While EMU subjects must be judicious in managing their accounts, a top level Commission official reminds us that "they

\footnotetext{
${ }^{56}$ William Walters, “Decentring the Economy," Economy and Society 28, no. 2 (1999): 315.
} 
simultaneously are mandated to advance the social strategies embodied in the Lisbon agenda." ${ }^{57}$ To navigate these constrained, and often overlapping, fields of regulated discretion necessitates a certain degree of creative entrepreneurialism in order to maximise public value. Potential crises are ever speculative threats that need to be mitigated whenever they may surface. To address this spatial and temporal diversity, the discourse of good times has to be malleable enough to be adopted and modified across this plurality of sites. Discretionary practices facilitate this adoption by tailoring context specific policies that target the unique exigencies confronting national policy-makers.

Now deciphering when good times actually arrive, and their duration, in order to activate the latent pro-cyclical aversion of EMU subjects is not without contestation. As I alluded to above, compliance may be compromised by a string of forecasting and measurement errors typically grounded in risk. Given that "uncertainty can affect compliance in that both the steering of a budget deficit and the recognition of the cyclical condition are less straightforward," inadvertent pro-cyclicality may be the result. ${ }^{58}$ Heterogeneous budgetary regimes across Europe complicate coordination by inserting this calculative uncertainty into the construction of good times as a dominant discourse.

Therefore, how confident can we be that the revised Pact is in fact the "best guarantee for commitments to be enforced and for all Member States to be treated equally" if it is fraught with such ambiguity? ${ }^{59}$ Collective action mandates some measure of referentiality in order for coordination to be successful. Monetary economists, such as Otmar Issing, submit that

\footnotetext{
${ }^{57}$ Joaquim Ayuso i Casals, interviewed by author, 3 May 2007.

${ }^{58}$ Waltraud Schelkle, "The Theory and Practice of Economic Governance in EMU Revisited: What Have We Learned About Commitment and Credibility?" 679.

${ }^{59}$ Council of the EU, Code of Conduct, 3.
} 
numerical reference values equip budgetary surveillance with a fixed point of reference that would otherwise not be present, thus encouraging compliance. ${ }^{60}$

Many commentators, of course, are incredulous of such assertions. Given the host of "exceptional" and "arbitrary" exemptions to the rules, combined with greater discretionary powers in their arbitration, they have pronounced the Pact de facto dead. ${ }^{61}$ Ambivalence persists given that this dialectical relationship between politics and expertise is not cemented but quite fluid and negotiable. Its parameters remain porous and "fuzzy," both conceptually and institutionally, as they are in the process of being redefined by this very interpenetration and overlap of governmental domains in the wake of the Ecofin crisis. But this leaves the process open to being held hostage by myopic political forces. The uncertainty of whether the Lisbonisation of macroeconomic policy will in fact jeopardise any strides at fiscal austerity or whether the discourse of good times can help relieve this tension and promote national fiscal ownership is yet to be determined. Nevertheless, the Commission is adamant that:

the 2005 revision of the Pact allows better account to be taken of cyclical conditions while strengthening medium and long-term fiscal discipline. The resulting framework is more demanding in good times, it affords more flexibility in bad times. ${ }^{62}$

Aware that opportunism is a real facet of political life, the Commission hopes to capitalise on cyclicality: periods when resistance to austerity is relatively subdued. In the struggle for representation, uncertainty is deployed to mobilise the preventative or corrective capacities of subjects as surveillance aligns itself with the creation of public value.

\footnotetext{
${ }^{60}$ Otmar Issing, The Birth of the Euro (New York: Cambridge University Press, 2008), 197.

${ }^{61}$ Willem H. Buiter, "The 'Sense and Nonsense of Maastricht' Revisited: What Have We Learnt about Stabilization in EMU?" Journal of Common Market Studies 44, no. 4 (2006): 687-710.

${ }^{62}$ European Commission, Communication from the Commission to the European Council- A European

Economic Recovery Plan (Report to the European Council, 16097/08, 2008), 9.
} 
If an apparent incongruency surfaces between framing the SGP problematic in terms of uncertainty and the contingency implicit in the communicative rationality that seeks to remedy it, then this may be attributed to the search for a transcendental centre as a referential anchor. Language, however, is constitutive of social relations whose "meaning depends upon a decentred system of contingently constructed rules and differences. ${ }^{, 63}$ As such, the meaning of good times is only temporarily fixed in and through discourse. Good times stem from the diverse ways that uncertainty is imagined and governed. Although formulas exist that help determine the present position in the business cycle, they cannot accurately forecast when that will be. Future variability and cyclical diversity need to be accommodated. Government through uncertainty modulates perceptions of cyclicality to help mobilise the endogenous responsibility of Member States to govern effectively within the confines of the SGP framework. An analytics of government allows us to monitor the constitution of normality or abnormality in correspondence to cyclical conditions. By unpacking the dominant discourse of good times, we become aware of its embeddedness in a technological infrastructure designed to render the SGP stabilisation visible. Uncertainty moderates the conditions of possibility underpinning this regulatory regime.

\subsection{The Preventative Arm: Technologies of Rule}

Decentred and variable, these sites of clustered convergence and divergence in European economic relations are apparently thwarting the quest for one single notion of normal good times as a template for fiscal governance across Europe. Their diverse foundations are uncertain and susceptible to the ever-changing conditions facing individual countries.

\footnotetext{
${ }^{63}$ Jacob Torfing, "Discourse Theory: Achievements, Arguments, and Challenges," in Discourse Theory in European Politics: Identity, Policy and Governance, ed. David Howarth and Jacob Torfing (New York: Palgrave, 2005), 8.
} 
Essentially, the fiscal landscape of Europe remains a fragmented collection of national policies interlaced via the Pact. Economic cyclicality simply reinforces this temporality of governance while undermining efforts at static forms of European macroeconomic risk management. Coordination and convergence asymmetries place a higher "premium on innovation and flexible adjustment" as the "sustainability and international competitiveness of the EU model comes to depend increasingly upon innovation and on its adjustment capacity for sustained growth." ${ }^{64}$ Again, this should not be interpreted in absolutist terms as the relationship between risk and uncertainty is not one of rigid binary opposition. Nor is the question of whether or not Europe is substantively a more "uncertain world" in the aftermath of the SGP crisis. Overlap is quite frequent, especially as expertise becomes reabsorbed into the political landscape. Officials housed in committees, such as the EPC or EFC, are finding that an effective execution of the Pact necessitates more room for critical judgement and seasoned interpretations of policy problems. Thus, recent amendments introduce a greater role for subjective estimations and decision-making.

An analytics of government reveals how the politics of uncertainty are reconfiguring what are considered proper ways of governing fiscal relations in response to the trinity of inconsistencies identified above. Increasingly, these mentalities rely on creative entrepreneurialism as a model of good fiscal government. A critical genealogy enables us to diagnose these assemblages as solutions and strategies for maintaining fiscal discipline. Through this deconstructive/reconstructive approach, we come to grasp how the managerial logics of uncertainty are programmed into these new technologies of rule, which aim to foster compliance across EMU. Having dissected how the narrative of good

\footnotetext{
${ }^{64}$ Annett Bongardt and Francisco Torres, "Is the 'European Model' Viable in a Globalized World?" in Globalization, Development and Integration: A European Perspective, ed. Pompeo Della Posta, Milica Uvalic, and Amy Verdun (New York: Palgrave Macmillan, 2009), 220.
} 
times is designed to activate the endogenous responsibility of Member States to judiciously manage their own uncertainty, a dissection of the preventative and corrective reforms demonstrates its resonance in practice. As they modulate budgetary conduct, these mechanisms increasingly validate non-quantitative forms of knowledge/expertise to promote convergence around the discourse of good times. Consequently, this signals a (re)politicisation of fiscal relations as political and social biases creep into the decisionmaking process. Here the second principal line of investigation behind this dissertation is addressed; namely what is the regulatory capacity through with uncertainty is delivered as a mode of governance?

An assessment of the Pact's experience in the first year following its revision in 2005 has convinced Ecofin that "positive" progress is being achieved. The "reformed SGP has stimulated a constructive and transparent economic policy dialogue at the EU level on the individual country cases, allowing the Council to reach unanimous agreement on all recommendations put forward by the Commission. ${ }^{.65}$ Structural adjustments are noticeable with a significant improvement in public finances. From a level of 2.5 percent of GDP in 2005, the headline deficit for the euro area declined in 2006 to 1.2 percent of GDP and again to 0.6 percent of GDP in $2007 .{ }^{66}$ Buoyant government revenues also accelerated the reduction of public debt, bringing it closer to the reference value for the euro area (67.5 percent in Q3 2008). ${ }^{67}$ Debt ratios witnessed a minimal drop reinforcing the focus on these

\footnotetext{
${ }^{65}$ Council of the EU, Press Release, 274 ${ }^{\text {th }}$ Council Meeting, Economic and Financial Committee, 11 July 2006, 11370/06 (Press 209) (Brussels: DG G1, 2006), 12.

${ }^{66}$ Eurostat, "General government deficit (-) and surplus (+); Percentage of GDP," (2009); The deficit rose to $1.9 \%$ of GDP in 2008 but that is when the credit crisis hit Europe.

${ }^{67}$ European Central Bank, The Statistics Pocketbook, January 2009 (Frankfurt: European Central Bank, 2009), 25.
} 
variables as preferred indicators of long-term sustainability. Fast growing economies may experience excessive deficits without necessarily jeopardising their long-term positions.

Whereas considerable advances have been applauded in relation to the dissuasive arm of the Pact, certain reservations remain about what progress is being made under the preventative arm. One of the biggest disappointments is France, where structural budgetary consolidation has stalled. With the Commission forecasting a budgetary deficit of 2.9 percent of GDP in 2008, originally estimated to be 2.4 percent of GDP in the Budget Bill, France was once again close to infringing upon the nominal value. In fact, it did as the figure jumped to 3.4 percent, prompting the Commission to issue a Report under Article 104(3), which formed the basis of an official Opinion (Article 104(6)) indicating that an excessive deficit did exist. In April 2009, a Council Decision (Article 104(7)) triggered the EDP against France. ${ }^{68}$ Its deficit is projected to hit 8.3 percent in 2009 and remain high for several years unless extensive consolidation is made.

Although a fragile ideational consensus that nominal targets do provide some referential utility remains, the new SGP begins to clarify the division of labour between Community institutions. It distinguishes assessment, by granting the Commission the "right to bark," from decision-making, or the "right to bite," which still falls exclusively into the province of the Council. ${ }^{69}$ Enhanced communication channels are anticipated to reduce the uncertainty of a fragmented fiscal landscape. One step in this direction is the vehicle of "policy advice." The Commission can now send direct recommendations to Member States in precarious positions in the hope of pre-empting potential violations. Closer

\footnotetext{
${ }^{68}$ Council of the EU, Council Decision of 6 April 2009 on the Existence of an Excessive Deficit in France, 7897/09 (Brussels: DG G1, 2009).

${ }^{69}$ Benoit Coeure and Jean Pisani-Ferry, "Fiscal Policy in EMU: Towards a Sustainability and Growth Pact," 608 ; the corresponding legal provision has been a victim of the rejection of the EU draft constitution.
} 
surveillance subjects governments to a regular review process, which is equipped with another mechanism that helps impart valuable information about how to use good times more effectively or how to adjust in periods when growth is below trend.

This opportunity allows the Commission to play a more proactive role in the management of government finances. A constructive dialogue may result that generates a positive momentum towards fiscal consolidation. Surveillance of this kind can promote policy learning and induce the internalisation of self-regulation as measures are taken to address and correct fiscal imbalances before the Council has to step in. Over time, the ambition of the Commission is to modulate the disposition of budgetary conduct away from profligacy by mobilising perceptions of economic uncertainty, relative to each Member State, in the effort to optimise fiscally prudent tendencies and minimise profligate ones. Policy advice is just one form of supervisory oversight that is being instituted to manage operational uncertainty. These developments are sure to inform the Stability and Convergence Programmes that governments submit annually, which outline the direction of national policy. Together a stronger role for the Commission may encourage convergence across EMU.

Compliance, however, may be hindered by the poor growth prospects facing the euro area. Sluggish performance, especially on part of the large economic motors like Germany, for much of this decade has pushed the rate of increase of European GDP below its potential growth. Staggering around the 1.5 percent level for most of 2005-06, its betterthan-expected upswing in 2007 was short-lived. ${ }^{70}$ More unsettling is the notion that any recovery from the credit crisis will be protracted and fragile. After all, as Jean-Claude

\footnotetext{
${ }^{70}$ European Commission: DG for Economic and Financial Affairs, European Economy: Public Finances in EMU 2009 (Brussels: DG EcFin, 2009), 1; In the current recessionary climate, economic growth has "come under unprecedented stress" and is projected to fall by $4 \%$ in 2009.
} 
Trichet conveyed to Le Monde, these are "unprecedented circumstances" and "uncertainty... is an important characteristic of the period that we find ourselves in." Estimated at about 2 percent, economic growth is compounded by the pre-eminence of the debt ceiling remaining at 60 percent of GDP. Large economies in particular will find their ability to manoeuvre severely curtailed given their feeble growth. Budgets will be strained by weaker tax revenues as governments strive to meet their expenditure obligations; making the relaxation of the Pact more illusionary than real.

To prevent potential conflicts, new forms of control link responsibility with fiscal ownership, which needs to be bolstered if uncertainty is to be mitigated. The differentiated MTOs, the MTBR, and the revised EDP are all technologies that address this concern. Through an interrogation of each one, we come to understand how the revised Pact signals an alternative mode of representing and managing the problem of fiscal affairs in EMU. This is by no means an exhaustive list. But it does reveal how this changing programmatic character is visible in both the preventative and corrective dimensions of the new fiscal framework.

A government through singular futures moves away from depoliticising techniques, such as structural regressions, which have been quite popular in attempts to determine the impact of fiscal policy on economic cycles. Unfortunately, whether it is macroeconometric modelling, Structural Vector Autoregression models (SVAR) or a mix of various methodologies, they all suffer from deficiencies that diminish their explanatory capacity. "Reliable results" are either contingent upon a large enough set of independent variables, specifying the correct lags, properly estimating the output gap, or a combination of such

\footnotetext{
${ }^{71}$ Jean-Claude Trichet, interview by Pierre-Antoine Delhommais and Arnaud Leparmentier, Le Monde, 17 November 2009.
} 
factors. ${ }^{72}$ However, as I noted earlier, just in relation to potential growth, a considerable output gap bias persists because of the uncertainty involved in its projection. ${ }^{73}$ With the introduction of greater discretionary surveillance, that uncertainty is only amplified as EMU abrogated the rules-based simplicity of the original Pact in favour of a "more sophisticated and nuanced framework. ${ }^{, 74}$ But there is more to be anxious about.

In addition to making the rules more complicated and less transparent, the administration of the Pact must now accommodate pressures stemming from the Lisbon strategy. Demand management policies need to process a substantial amount of accurate information in order to be successfully implemented, especially when confronted with a monetarist European Central Bank. As a result, "in an environment of limited knowledge about economic relationships and parameters an activist approach to policy could easily introduce additional uncertainty into the system rather than perform a stabilising function." ${ }^{, 75}$ Straight-forward and simple, the new SGP is not. Clarity has been replaced with considerable ambiguity, whose uncertain effects EMU officials are now charged with interpreting and managing.

Unique situations are not readily susceptible to the depoliticisation and aggregation of risk management. A better method anchors their governance within a specific temporal trajectory. Attuned to and underscoring contingency, mapping the governmental modality of uncertainty demonstrates the spatiality and historicity of EMU. For all its supposed

\footnotetext{
${ }^{72}$ Michael J. Artis and Luca Onorante, "The Economic Importance of Fiscal Rules," in The Travails of the Eurozone: Economic Policies, Economic Developments, ed. David Cobham (New York: Palgrave Macmillan, 2007), 125-26.

${ }^{73}$ Waltraud Schelkle, "The Theory and Practice of Economic Governance in EMU Revisited: What Have We Learned About Commitment and Credibility?" 679.

${ }^{74}$ Martin Heipertz and Amy Verdun, "The Dog That Would Bark but Never Bite? Origins, Crisis and Reform of Europe's Stability and Growth Pact," 133.

${ }^{75}$ Bernard Winkler, "Stability and Growth: The Role of Monetary Policy and Other Policy Actors in EMU," 167.
} 
statistical intelligibility and congruence this space is an artefact derived from diverse influences. Contingency simply contributes to the contestation implicit in its construction. To properly understand this emerging spatial-temporal order, we must interrogate the mechanisms deployed in its constitution. These comprise the following sections.

\section{Country Specific Medium-Term Budgetary Objectives}

Abstract models, that neglect conditionality, cannot account for the contextual but random character of uncertainty as an organising principle that helps define the parameters of EMU as a governable space. This demands that regulators exercise creative foresight by appreciating the contingency and political character underpinning fiscal relations. Furthermore, it calls into question what is legitimate and highlights the nature of the leverage implicit in establishing claims of normalcy and responsibility underlying EMU politics. MTOs are deliberately deployed to manage the threat of fiscal profligacy in terms of uncertainty.

Risk metrics (e.g. Value-at-Risk) remain a popular tool in prudential supervision and financial stability in Europe. Buti and Giudice even derive a fiscal reaction function from the projected output gap and inflation stabilisation. ${ }^{76}$ All things considered, however, these quantifiable estimations are most visible in securing the primary objective of the ECB; namely price stability. Inflationary concerns about the deficit bias are just as prominent with the 2005 reforms. But their monopoly at the expense of employment and economic growth has been disturbed. With the original Pact, optimal fiscal rules were devised in a similar vein to monetary policy. Ostensibly, the initial SGP attempted to transpose a monetarist rationality, with its associated techniques, onto a politically charged

\footnotetext{
${ }^{76}$ Marco Buti and Gabriele Giudice, "Maastricht's Fiscal Rules at Ten: An Assessment," Journal of Common Market Studies 40, no. 5 (2002): 823-48.
} 
fiscal landscape that did not lend itself to such measures. Specifically, importing this strategy neglected that "Knightian uncertainty, in particular uncertainty about the goals of monetary policy, is by and large ignored" by central bankers. ${ }^{77}$ Fiscal conduct, on the other hand, is more pervious to unsuspecting socio-political forces and thus amenable to a different regulatory approach akin to uncertainty.

The revised Pact recognises that unforeseen events evade being captured in a prior distribution. Without these quantifiable parameters, risk modelling is challenged by the demand for ever adaptive governance techniques. In deciding how to amend the Pact to make it operative, the Council was adamant that binding economic rules need to be rejected because, with uncertainty, strict adherence jeopardises welfare given the cost of not adapting to shocks. ${ }^{78}$ On the other hand, the Commission advocated that rules are a significant feature of any successful organisation. They address the problem of collective action and prevent arbitrary conduct from undermining the common monetary policy. In the end, nominal targets have been retained for the sake of a credible monetary union. The Commission noted that this approach has:

proven its usefulness in anchoring budget deficits, thereby contributing to a high degree of macroeconomic stability with low inflation and low interest rates, which is necessary to induce sustainable growth and employment creation. $^{79}$

The position, however, that fiscal uniformity must be imposed across countries, irrespective of macroeconomic objectives, through a "one-size-fits-all" policy has been discredited.

\footnotetext{
${ }^{77}$ Helene Schuberth, "Knightian Uncertainty, Accountability and Economic Policy Rules," in Economic Policy under Uncertainty: The Role of Truth and Accountability in Policy Advice, ed. Peter Mooslechner, Helene Schuberth, and Martin Schürz (Northampton: Edward Elgar, 2004), 262.

${ }^{78}$ Ibid, 261.

${ }^{79}$ European Commission, Proposal for a Council Regulation: Amending Regulation (EC) No $1466 / 97$ on the Strengthening of the Surveillance of Budgetary Positions and the Surveillance and Coordination of Economic Policies, 20.4.2005 Com (2005) 154 final.
} 
Under the new provisions of the preventative arm, Member States are still mandated to submit annual SCPs delineating how they intend to achieve or safeguard sound fiscal positions in the medium-term (the current year and at least three subsequent fiscal calendars). At the heart of multilateral surveillance in EMU, SCPs are assessed by the Commission and the Council renders an Opinion. Reporting current macroeconomic conditions, from which future budgetary proposals are derived, in a regular and systemic fashion, helps ensure the consistent application of SGP statutes; thus safeguarding the sustainability of public finances. Complementarity is enhanced "without prejudice to the balance between national and Community competences" because their implementation is also "discussed at the European level in the context of the Stability and Convergence Programmes. ${ }^{, 80}$ What were primarily passive documents are now subject to political scrutiny at various levels of government.

With the transition to uncertain modes of governance, these SCPs now include differentiated medium-term budgetary objectives. At the heart of the preventative arm, they replace the economic rationale advocating the uniform requirement of CTBOIS with new methodologically clarified MTOs. Regulation 1055/2005 amends the original Regulation 1466/97 abrogating this initial misguided alignment. The "adoption of new, looser medium-term targets implicitly recognises the lack of rationale of the close to balance or in-surplus requirement which, if continuously respected, would drive debt ratios to zero or even negative values." ${ }^{\prime 81}$ In its revamped form, the Pact permits divergence so as to account for heterogeneous economic developments and fiscal asynchronicity across EMU. This entails a shift to the prioritisation of the long-term sustainability of public finances.

\footnotetext{
${ }^{80}$ Council of the EU, Code of Conduct, 3.

${ }^{81}$ Michael J. Artis and Luca Onorante, "The Economic Importance of Fiscal Rules," 124.
} 
Of course, greater MTO flexibility is conditional on Member States fulfilling three objectives stipulated in the new SGP. These include: (1) providing a safety margin with respect to the 3 percent of GDP government ratio; (2) ensuring rapid progress towards sustainability; and (3) allowing room for budgetary manoeuvre. ${ }^{82}$ Particularly problematic is the last of these because it is extremely difficult to quantify since it encompasses changing expenditures, such as public investment, which fluctuate with business and electoral cycles. Yet it is exactly this purview that national governments want to retain. Uncertain when they will materialise or what their exact nature will be, through the differentiated MTOs, these national demands can now be accommodated without jeopardising the integrity of the entire fiscal framework.

Prevention of excessive expenditure entails expanding the latitude available to governments in drawing up their budgetary plans into areas not previously covered under the Pact while simultaneously controlling of scope of this activity. MTOs "shall be specified within a defined range between -1 percent of GDP and balance or surplus, in cyclically adjusted terms, net of one-off and temporary measures." ${ }^{, 83}$ Low debt/high potential growth economies warrant greater flexibility at -1 percent, while their high debt/low potential growth neighbours must meet the more stringent "balance or in surplus" criterion. A benchmark of 0.5 percent of GDP is the agreed upon adjustment path to reach the MTO. These measures seek to strike a compromise between sustainability and stabilisation; an endeavour which is itself fraught with uncertainty. As Heipertz and Verdun remind us:

\footnotetext{
${ }^{82}$ Council of the EU, Council Regulation (EC) No 1055/2005: Amending Regulation (EC) No 1466/97 on the Strengthening of the Surveillance of Budgetary Positions and the Surveillance and Coordination of Economic Policies, 7.7.2005, EC(2005), 4.

${ }^{83}$ Ibid, 4.
} 
like any compromise solution, the SGP can be criticised from several angles. It can neither be a substitute for an efficient, mature and full-blown institution, nor does it offer a guarantee against budgetary irresponsibility. It certainly sometimes strikes an awkward balance between on the one hand the degree of simplicity that is made necessary by EMU's political economy and on the other hand today's complexities of public finance. ${ }^{84}$

At once, Member States are afforded enough room to navigate normal cyclical conditions but are simultaneously controlled in how they exercise that discretion. MTOs exert this leverage in the promotion of enhanced self-regulation.

In addition to managing national exigencies, the revised Pact recognises that the successful restitution of the fiscal framework entails mitigating any possible externalities which result from the process of integration itself. These "awkward balances" are often temporary and quite fragile. We simply have to look at the original Pact to realise that political protocols are contested and provisional stabilisation. No matter how solid they first appear, their political nature makes them assailable and uncertain. Of course, these negotiated compromises can be maintained. But that means permitting enough flexibility to accommodate changing interests in such a manner that does not adversely affect compliance. For this purpose, managing perceptions of uncertainty is a vital component to garnering sufficient support for the Pact.

A genealogical analysis captures how EMU control mechanisms, such as MTOs, condition the tendency among Member States towards profligate behaviour while retaining some semblance of institutional coherence. By problematising their capacity to influence discretionary behaviour, we apprehend how MTOs increasingly validate non-quantitative forms of control. A growing fixture in the design of these guidelines, it reflects the attitude that officials need to be able to adapt to changing conditions and allow fiscal policies to

\footnotetext{
${ }^{84}$ Martin Heipertz and Amy Verdun, "The Dog That Would Bark But Never Bite? Origins, Crisis and Reform of Europe's Stability and Growth Pact," 119.
} 
stabilise the economic cycle. In order to govern properly, discretion is necessary because we cannot forecast all destabilising exigencies with any degree of accuracy. This managerial task is only complicated by the weak growth plaguing Europe. Country-specific MTOs, however, are seen as a step in addressing this potential disjuncture between fiscal discipline and economic prosperity. By catering to unique conditions, they make the Pact more sensitive to contextuality, thus dulling its arbitrary posture.

For the first time these differentiated MTOs must be included in the SCPs. In these, governments are obligated to present a comprehensive assessment of their liabilities. This includes both their explicit (current debt levels) and implicit accounts. As noted above, the latter calculates the burden to state coffers associated with an ageing population. At the time of writing, clear criteria and modalities used to account for these liabilities had yet to be established. The Commission is entrusted with that function. In their absence, potential growth and current debt ratios are employed in determining MTOs until such a methodology becomes available. ${ }^{85}$

Inaccurate growth projections, as I have argued, have the potential to aggravate attempts at internal control and operational uncertainty; especially in light of an egregious negative bias visible in calculating the output gap. Outstanding definitional problems simply exacerbate the difficulty of measuring the costs and benefits of structural reform. Rather than alleviating the externalities surrounding fiscal relations, the new preventative arm may, arguably, contribute to it. Fortunately, the EFC was aware of this internal control predicament. Hence, a regular review process facilitates necessary revisions of MTOs when appropriate so that they actually correspond to good or bad times. Closer surveillance

\footnotetext{
${ }^{85}$ European Commission: DG for Economic and Financial Affairs, European Economy: Public Finances in EMU 2008 (Brussels: DG EcFin, 2008), 107.
} 
promotes active engagement between national governments and Community institutions, thereby fostering a heightened sense of fiscal ownership over the framework. This movement is further bolstered by mechanisms, such as the medium-term budgetary review, which I address shortly.

One advantage accruing from this continuous feedback loop is the modernisation of public administrations across Europe. As opposed to being conceived of as a static and enclosed field, as perpetuated under risk management, budgetary surveillance is proving to be a dynamic and evolving process. In the construction of this communicative space, regular Commission monitoring - together with the enhanced dialogue it produces - is eliciting transformations in how individual Member States manage their fiscal books. The Council believes modernisation has the potential to diminish destabilising threats to its economies, by improving competitiveness and the delivery of services, while achieving better value for money and controlling costs. However, efforts to improve the efficiency and effectiveness of these regulatory systems need to account for their capacity to create public value as opposed to sheer cost cutting. The objectives of the Lisbon strategy must be reconciled with those of the SGP.

To facilitate this process, the Economic Policy Committee, whose mandate is to assist Ecofin and foster economic cooperation, has identified four areas where quality improvements should be concentrated. In its opinion, these include: a greater performance orientation of public budgets, a reorganisation of public administrations, reforms in human resource management, and improved use of ICT (information and communication technology) tools. ${ }^{86}$ By focusing on medium-term performance while simultaneously

\footnotetext{
${ }^{86}$ Council of the EU, Press Release, $2822^{\text {th }}$ Council Meeting, Economic and Financial Committee, 09 October 2007, 13571/07 (Press 217) (Luxembourg, 2007), 10.
} 
streamlining their organisational apparatus, it is thought that MTOs can help address internal control and operational challenges by reducing unnecessary bureaucratic costs and the temptation of pro-cyclical behaviour. Performance-Based Budgeting (PBB) techniques, and in particular programmes such the Medium-Term Expenditure Frameworks (MTEF), are proving successful in the Netherlands and the Scandinavian countries. ${ }^{87}$ At present, however, pure PBB systems are rare given institutional resistance to change and contestation over performance measurability.

Performance-Based Budgeting has garnered greater attention as a managerial form since fewer resources are increasingly stretched to encompass more programmes. Linking accountability with public value creation has become a politically sensitive topic. No longer is it sufficient enough to merely focus on the allocation of expenditures without assessing the efficiency of its output or outcome. ${ }^{88}$ Such a conventional input-oriented budgetary approach is costly and prone to inefficiencies. Moreover, it fails to account for how results can complicate further organisational efforts and subsequent fiscal allocations. Conversely, PBB addresses how budgetary initiatives get translated into actual tangibles that reach European consumers and citizens. Donating more attention to the link between the composition of policy and the outputs it generates helps contribute to the transparency of outcomes and mitigates perceptions of uncertainty. Throughout Europe, there are signs of its progressive adoption; especially in prioritised areas such as health care and education. ${ }^{89}$

\footnotetext{
${ }^{87}$ Economic Policy Committee, "Initiatives to Improve the Efficiency and Effectiveness of Public Spending: Modernising Public Administration," (REP/53684 rev. 2, 2008).

${ }^{88}$ European Commission: DG for Economic and Financial Affairs, European Economy: Public Finances in EMU 2007 (Brussels: DG EcFin, 2007), 124-25.

${ }^{89}$ Teresa Curristine, "Performance Information in the Budget Process: Results of the OECD 2005 Questionnaire," OECD Journal on Budgeting 5, no. 2 (2005): 87-131.
} 
A sense of enhanced stability and transparency is welcomed as it also helps to reinforce the credibility of the Pact, which was tarnished by the addition of new, complex provisions. Differentiated MTOs magnify the preparation of national macroeconomic programmes thereby endowing medium-term budgetary targets with a degree of political capital previously absent. A more attentive appraisal of underlying economic assumptions, projections and policy proposals enhances the transparency of the budgetary process. Simultaneously, it guards against the temptation to embellish figures through the opportunistic use of MTOs. The risk of misrepresentation is mitigated as enhanced surveillance dissuades governments from presenting an excessively rosy report which lacks support in reality.

Compliance is produced by calculable subjects whose discretion to arrange their fiscal affairs is presupposed by the very technologies of government that seek to shape this conduct. Member States come to understand themselves as performance regulating entities, albeit ones faced with informational and calculative asymmetries consequent of their fluid political economies. It is here that the performative character of MTOs, as technologies of power, is revealed. They mobilise particular dispositions of uncertainty in the instrumentalisation of fiscal austerity as represented by effective and efficient performance. Thus, the better Member States perform, the less uncertainty they face.

On the topic of budgetary preparation, it is significant to distinguish between forecasts and the revision of actual targets; including the path to their actualisation. Are the projections attainable under unchanged policies or will additional measures be necessary in order to compensate for the introduction of new variables? In other words, how is uncertainty deployed in structuring the necessary internal controls involved in supervising 
the budgetary planning process itself? Feedback loops are common in EMU where interactions at various levels of government compel decision-makers to adapt to changing opinions and circumstances and adopt new policy methods/directions. Economic outlooks are notoriously susceptible to being derailed by both exogenous and endogenous shocks. Since the assumption "of practical omniscience on part of every member of the competitive system" is unrealistic, political planning in a highly centralised form is challenged. ${ }^{90}$ It cannot predetermine, with any high degree of accuracy, how policy-makers will behave in all stages of the budgetary planning process, especially in a policy arena as diverse and fragmented as the EU. Flexible MTOs represent this looping effect as they are open to modification and stipulate how adjustments are to occur. The original Pact never allowed for such provisions.

Economic growth and employment strategies may open new worlds of opportunity. But they simultaneously contribute to fresh mechanisms of control whereby government action is modulated at multiple sites. We witness the collision of sovereign and control forms of government where the onus rests with the creative entrepreneurialism of Member States to navigate waters bridging collectivised and individuated budgetary planes.

Although certain rules and norms do exist, these are by and large uncharted waters. Against this backdrop it is possible to diagnose the reabsorption of the technocratic sphere into the political as a particular response to the problems of fiscal profligacy and collective action in terms of public value creation.

This Lisbonisation of expertise is revealed through a genealogical excavation of the MTO as a socio-technical practice of intervention that territorialises the SGP as a governmental plane. As it relaxes the strict adhere to a poorly constructed uniform

\footnotetext{
${ }^{90}$ Frank Knight, Risk, Uncertainty and Profit, 197.
} 
requirement of CTBOIS, the MTO is redesigned to embed the narrative of good times as it reformulates expertise to balance national interests with Community obligations under conditions of uncertainty. Now Member States can set their own fiscal targets. Yet, as Schelkle notes, there is still ambivalence about the involvement of parliaments in drafting and sanctioning the SCPs and their MTOs. ${ }^{91}$ As national legislatures are slow to wade deeper into fiscal surveillance, it retains its regulatory dimension. Eurostat is entrusted with developing and assessing budgetary statistics, which subjects Member States to common accounting standards. Although some harmonised risk systems remain intact, creativity is increasingly harnessed and optimised through new technologies in order to secure a prudent adjustment path to the medium-term objective. Here national fiscal ownership is reconciled with broader SGP principles.

\section{Medium-Term Budgetary Review}

With the Lisbonisation of macroeconomic governance, more than ever, "fiscal policy is at the centre of domestic democratic politics."92 This proposition virtually constitutes an axiom of EMU if one such exists. Another commonly accepted "truth" is that national fiscal ownership is fundamental for the success of not only the preventative arm but the entire EMU. Attributing the demise of the original Pact to the lacklustre involvement of national institutions, the Council is adamant that these need to "play a more prominent role in budgetary surveillance to strengthen national ownership, enhance enforcement through national public opinion and complement the economic and policy analysis at the EU

\footnotetext{
${ }^{91}$ Waltraud Schelkle, "The Contentious Creation of the Regulatory State in Fiscal Surveillance," West European Politics 32, no. 4 (2009): 839.

${ }^{92}$ Kenneth Dyson, "The First Decade," in The Euro at 10: Europeanization, Power, and Convergence, ed. Kenneth Dyson (New York: Oxford University Press, 2008), 24.
} 
level." $" 93$ As the new "Code of Conduct" stipulates, the improvement and sustainability of public finances is predicated on effective peer support and peer pressure establishing transparent and credible monitoring procedures. ${ }^{94}$ Unless Member States demonstrate a clear and decisive political commitment to the proper maintenance of their own books, symmetrical and effective multilateral surveillance remains in doubt. To this end, a strategic dialogue, in the form of the Medium-Term Budgetary Review (MTBR), is scheduled to evaluate the updated SCPs in order to ensure compliance with the statutes.

Whatever faith remains in the disciplinary effect of rules has allowed them to be retained as the centrepiece of multilateral surveillance. Of course, now the architects of EMU recognise the precariousness of relying disproportionately on numerical guideposts for effective fiscal governance. If excessively rigid, rules are breached; if overly lax, they prove redundant. In themselves, fiscal rules are not sufficient enough to either guarantee compliance or promote convergence. Only as stakeholders are governments perceived to assume greater responsibility for their budgetary conduct in a manner that is conducive to the broader goals of European integration. The MTBR is intended to help facilitate this process by engaging individual Member States in a serious political discussion about their forthcoming budgets.

Through an analytics of government, we come to understand how this consultative programme reflects the changing way that fiscal relations are being framed after the SGP crisis. As a supervisory mechanism, the MTBR is deployed to mitigate the uncertainties implicit in poor policy design and feeble internal control. Simultaneously, the Commission recognises that through enhanced dialogue, they are in a position to exert greater leverage

\footnotetext{
${ }^{93}$ Council of the EU, Brussels Spring European Council: Presidency Conclusions, 22 and 23 March 2005, 26.

${ }^{94}$ Council of the EU, Code of Conduct.
} 
over Member States. Here the MTBR has the potential to function as a sanctioning device, which, through peer pressure, increases the reputational costs of reneging on SGP promises or political opportunism. On the one hand, the revised Pact has weakened the Commission to a considerable extend by stripping it of the authority it derived from a "hard" rules-based system. On the other hand, the Commission is managing to remain a relevant force by modifying how it exercises its power. Modulating fiscal conduct through more subtle discursive practices may yield the desire compliance and eventual convergence.

In its March 2005 report, the Council noted that the Eurogroup will provide both country-specific conclusions and a "horizontal assessment of national budgetary developments and their implications for the euro area as a whole." $" 95$ According the Eurogroup, the purpose of the MTBR is twofold: (1) to ensure a proper coordination of national fiscal policies in the euro area; and (2) to provide sufficient peer support and pressure for sound fiscal policies at the national level. ${ }^{96}$ By specifying how fiscal programmes will achieve balanced budgets in a sustainable manner, it is possible to minimise the mismatch between budgetary positions and cyclical conditions. In the longterm, the tension between fiscal stabilisation and debt sustainability is recalibrated as convergent forces help regulate variable policies.

To deliberate the merits of recent budgetary circumstances and ensure the effective coordination of national fiscal policies, the MTBR is executed before the summer. Prevention is purportedly enhanced since this redesign is more complementary to national budgetary calendars. ${ }^{97}$ Assessable consultations at this juncture occur after the presentation

\footnotetext{
${ }^{95}$ Council of the EU, Improving the Implementation of the Stability and Growth Pact, 6.

${ }^{96}$ European Commission: DG for Economic and Financial Affairs, European Economy: Public Finances in EMU 2007, 74.

${ }^{97}$ Ibid, 65.
} 
of the updated Stability and Convergence Programmes but prior to the next round of budgetary planning. At this early stage, the MTBR can shape the national debate before budgets are finalised. It can encourage domestic reforms leading to the update of national fiscal frameworks and the closer convergence of policy. ${ }^{98}$

Concurrently, Member States are invited to submit any information on their policy intentions that they deem pertinent in order to foster a comprehensive discourse about fiscal programmes. In the past, the MTBR typically reflected the risk projections endorsed in the spring Commission forecasts, which adhered a "no-policy-change" mentality. To be incorporated, a fair degree of certitude about programmatic detail was necessary. Consequently, "static models of change...made the content of new institutions a determinate function of the problems faced by previous institutions." ${ }^{.99}$ Characteristic of risk analysis, this approach fails to compensate for policy intentions which are merely being entertained but evade being assigned a statistical vector in regards to their probability. Uncertainty is being neglected. To ameliorate this omission, thus enriching the budgetary surveillance process, the Eurogroup now welcomes the incorporation of such speculative agendas. The Commission is entrusted with evaluating this information in the preparation of forthcoming MTBR discussions. ${ }^{100}$

Improved communication and the mobilisation of uncertainty in these redesigned fora provide a better reference of normality in the management of the contingency implicit in fiscal relations. Such a strategic dialogue "underlies the important role that national

\footnotetext{
${ }^{98}$ Mark Hallerberg and Joshua Bridwell, "Fiscal Policy Coordination and Discipline: The Stability and Growth Pact and Domestic Fiscal Regimes," in The Euro at 10: Europeanization, Power, and Convergence, ed. Kenneth Dyson (New York: Oxford University Press, 2008), 69-86.

${ }^{99}$ Mark Blyth, Great Transformations: Economic Ideas and Institutional Changes in the Twentieth Century (New York: Cambridge University Press, 2002), 9.

${ }^{100}$ European Commission: DG for Economic and Financial Affairs, European Economy: Public Finances in EMU 2007, 74.
} 
fiscal rules and institutions can play in the attainment of sound budgetary positions and in the respect of the provisions of the Treaty." ${ }^{101}$ National fiscal ownership is heightened as closer collaboration improves the identification, assessment and execution of MTOs and the fiscal programmes in which they are embedded. Better overall coordination translates into more prosperous economic conditions as states become less susceptible to idiosyncratic shocks spilling over. Buoyed by favourable markets, constraints on fiscal freedom become more tolerable as the Pact becomes more palatable.

Initiatives of this sort demand that governments exercise their creative entrepreneurial skills in negotiating the different challenges facing them. The Commission, through the MTBR, is in a position to assist. Complex technical analysis is often fraught with numerous complications since the field of economics is splintered into competing camps each professing to possess the "correct" fiscal model. ${ }^{102}$ Earlier, I noted how incredulous a single notion of "reliability" is given that these models each emphasise distinct variables in their atomisation of economic relations. Whether it is structural vector autoregression modelling (SVAR) or something else, varying techniques applied in different contexts may produce incompatible results. Even "debt sustainability analysis:"

is a fancy label for what simply amounts to a small simulation model of the evolution of the public debt, with assumptions about, inter alia, interest rates, growth rates, and the growth effects of different forms of public spending. The results that one gets out depend on the assumptions one puts in. And, in practice, many of the key assumptions are at best arguable and at worst arbitrary. ${ }^{103}$

Moreover, volatile political forces often remain peripheral in these calculations.

\footnotetext{
${ }^{101}$ Council of the EU, Press Release, $2753^{\text {th }}$ Council Meeting, Economic and Financial Committee, 10 October 2006, 13600/06 (Press 278) (Luxembourg, 2006), 16.

${ }^{102}$ Michael J. Artis and Luca Onorante, "The Economic Importance of Fiscal Rules," 125-42.

${ }^{103}$ Barry Eichengreen, "Europe, the Euro and the ECB: Monetary Success, Fiscal Failure," Journal of Policy Modeling 27 (2005): 434.
} 
A case in point is Greece. Originally, it predicted a deficit of only 2.2 percent of GDP in its 2006 stability programme but experienced a loss of 3.5 percent of GDP in 2007. Its budgetary target for 2009 was an even more optimistic -2 percent of GDP. But that projection assumed the customary "no-policy-change" clause similar to most risk models. Credit crisis corrections, which are in part the result of reckless risk metrics, have sabotaged those plans. Whereas the Commission originally estimated the actual deficit would balloon to 4.2 percent of GDP by 2010 , the newly elected Socialist government now admits that the figure will be closer to 12.7 percent. ${ }^{104}$ A revision of 8 percent - blamed on expenses relating to unpaid medical suppliers - has compelled the rating agency Fitch to downgrade the status of its bonds from A to A-. ${ }^{105}$ With the public debt expecting to top 135 percent of GDP in 2011, the Commission has pronounced that Greece has taken "no effective action" towards fiscal consolidation. A new austerity programme will be introduced early in 2010 and monitored through the MTBR. But with the common belief that Greece will be bailed out by its more prudent euro area neighbours, it is difficult to image that the necessary severe cuts will be expedient.

A discrepancy also surfaced between Finland's 2006 stability programme projections and its actual 2007 budgetary position. In contrast to Greece, however, its surplus more than doubled to 5.3 percent of GDP. Debt ratios for Greece and Finland were also far apart (94.8 percent and 35.1 percent of GDP respectively). ${ }^{106}$ Identical prescriptions are inadequate in such diverse situations. In order to formulate proper fiscal policy and reduce the uncertainty surrounding the coordination of such divergent national

\footnotetext{
${ }^{104}$ European Commission: DG for Economic and Financial Affairs, Interim Forecasts (DG EcFin, 2009); available from http://ec.europa.eu/economy_finance/pdf/2009/interimforecastjanuary/ el.html.

105 "Arithmetic Lesson," The Economist, November 21, 2009, 53.

${ }^{106}$ European Central Bank, The Statistics Pocketbook, January 2009.
} 
positions, a flexible system is necessary. It allows the Commission a better opportunity to structure the ensuing MTBR discussion. The objective is a more in-depth strategic policy dialogue that focuses on areas in need of improvement. To help establish budgetary priorities and curb deficits, Savage and Verdun advocate instituting "programmatic spending caps" as a percentage of GDP. ${ }^{107}$ Fixed targets are thought to provide an infrastructure of referentiality, around which discussions may be structured and help mitigate the uncertainties of fiscal conduct.

Whether it is wise to vest considerable discretionary power in the hands of Commission technocrats is quite contentious. Irrespective of the conclusions that these MTBRs draw, however, it remains the prerogative of the Ecofin Council to either accept or reject Commission recommendations. Any "institutional fusion" of the kind contemplated by Wessels, in the fiscal domain, is still far removed from actuality. ${ }^{108}$ But even though the MTBR is an individualising technology of government that "relativises identities by penetrating or dissolving boundaries around relatively closed systems," it simultaneously "creates trans-societal and post-territorial discursive spaces and networks of relations."109

While focusing on national fiscal programmes and intentions, these strategic dialogues also take into account the euro area as a whole in their appraisal. Increasingly, national and Community objectives are perceived as congruous and their interests as interwoven. Of course, this is not to insinuate the existence of a coherent, supranational fiscal entity. Rather these discussions recognise that adverse effects, derived from unique

\footnotetext{
${ }^{107}$ James D. Savage and Amy Verdun, "Reforming Europe's Stability and Growth Pact: Lessons from the American Experience in Macrobudgeting," Review of International Political Economy 14, no. 5 (2007): 863. ${ }^{108}$ Wolfgang Wessels, "An Ever Closer Fusion? A Dynamic Macro-political View on Integration Process," Journal of Common Market Studies 35, no. 3 (1997): 267-99.

${ }^{109}$ Barrie Axford and Richard Huggins, "Towards a Post-National Polity: The Emergence of the Network Society in Europe," in Whose Europe? The Turn Towards Democracy, ed. Dennis Smith and Sue Wright (Oxford: Blackwell, 1999): 121-47.
} 
uncertainties, often spillover across borders and interfere with economic development in other jurisdictions. Controlling instances where such deviation may occur, the MTBR serves to pre-empt any negative ramifications which may be amplified by monetary and economic interdependence. In the process, the EMU space is attributed a certain degree of materiality and rendered real as an artefact of government.

As national fiscal spaces are opened up, the EMU plane itself assumes both a greater spatial and temporal density through the MTBR. By penetrating the national fiscal landscape, the MTBR modulates the design of budgetary policy to a degree not previously visible. At the core of this assessment is the problematisation of state competence in terms of time. The MTRB addresses the management of fiscal affairs in a temporal fashion. It seeks to fix national forces at particular junctures when they are most susceptible to effective control; namely prior to any budgetary finalisation. Rather than merely going through the motions and rubberstamping a predetermined spring Commission forecast, the redesigned MTBR presses ahead with the interrogation of fiscal relations at their specific sites and respective times.

Here power "works in part through its ability to name, to define and to describe certain people and places as being different from others." ${ }^{110}$ Reputational uncertainties may be managed as with Greece. Outside EMU, it would be subject to intense criticism and market discipline. However, since the investors are convinced that a bail out is possible, but not imminent, the Greek 10-year bond yield remains under 5 percent irrespective of its highly dubious budgetary position. As Leblond alluded to above, similar confidence in the

\footnotetext{
${ }^{110}$ Wendy Larner and Richard Le Heron, "Global Benchmarking: Participating 'At a Distance' in the Globalizing Economy," in Global Governmentality: Governing International Spaces, ed. Wendy Larner and William Walters ((London: Routledge, 2004), 219.
} 
long-term sustainability of public finances was observed during the Ecofin crisis. ${ }^{111}$ This politics of representation, mediated by the MTBR, renders certain EMU stabilisations visible and therefore manageable. But these fiscal configurations are temporary and constantly undergoing transformation as they are confronted with domestic, regional and global forces of change. To judiciously regulate fiscal relations means to effectively manage time. The current reforms are one step in that direction as they recognise the temporal contingency underpinning economic surveillance.

The ambition is to mitigate uncertainty by remedying the "discrepancy between cognitive capacities and situational complexity." $" 112$ Enhancing how and when information is processed can determine the course of action pursued. It can modify how the fiscal experience is temporally framed and influence the pace of adjustment. Each national fiscal situation is imbued with its own particular historicity and spatiality that inform how amenable it is to various forms of multilateral surveillance. Again, we simply have to compare Greece and Finland. Through the MTRB technique, the Commission can modulate its regulatory approach depending on the context and time, thus steering both national debate as well as broader euro area development.

Expertise is once again in the process of being reabsorbed by competing political forces as it conforms to the management of disparate good times at a plurality of sites. As these vary across Europe, each country needs to be assessed on its own merits and action plans must be drawn up that reflect its unique reputational and operational challenges. By

\footnotetext{
${ }^{111}$ Patrick Leblond, "The Political Stability and Growth Pact is Dead: Long Live the Economic Stability and Growth Pact," Journal of Common Market Studies 44, no. 5 (2006): 969-90.

112 Jens Beckert, Beyond the Market: The Social Foundations of Economic Efficiency (Princeton, N.J.: Princeton University Press, 2002), 40.
} 
complementing the differentiated MTOs, the MTBR reaffirms the commitment to the Lisbon strategy while strengthening the levers of multilateral surveillance.

But the political economy of surveillance is itself transforming. We come to a better understanding of this movement through a deconstructive/reconstructive analytic. What it reveals is that, to elicit compliance with the fiscal rules, the Commission is compelled to readjust its managerial approach and adopt less intrusive methods as it strives to combat fiscal profligacy. Aware of its diminished power vis-a-vis the Member States, it is progressively relying on subtler forms of peer pressure and peer support to help promote convergence while addressing the asymmetrical contingencies facing European countries. This necessitates framing the problems of fiscal management though a government of singular futures rather than aggregating what are constellations of heterogeneous political economies.

In this effort, the MTBR is deployed to align discretionary conduct with selfregulatory forms of budgetary compliance. The hope is to foster an enhanced sense of national fiscal ownership of the Pact. Whether this proves effective depends on the degree of control that can be manufactured through this preventative technology within the broader communicative space of EMU. Convergence may actually accelerate since integration "means to connect singularities, to homogenise them and make them converge qua singularities towards a common goal."113 That shared objective is the stability and prosperity of EMU. For it to materialise, however, it must accommodate plural notions of normalcy. The MTBR blurs the distinction between national and EU conceptions of what is normalcy is and how to attain it.

\footnotetext{
${ }^{113}$ Maurizio Lazzarato, "Life and the Living in the Societies of Control," in Deleuze and the Social, ed. Martin Fuglsang and Bent Meier Sorensen (Edinburgh: Edinburgh University Press, 2006), 174.
} 


\subsection{The Corrective Arm: Technologies of Rule}

Beset with problems right from its introduction in 1999, the euro quickly depreciated against the dollar and the entire regime looked vulnerable as Italy seemed unable to meet its budgetary obligations. Italy, as it proved, would not be the only headache to afflict EU policy-makers nor would it be the most severe. Monetary concerns were soon overshadowed by a crisis that hit the fiscal framework accentuating how divisive the problem of collective action can be without a central fiscal authority or credible sanctions. Fiscal austerity, with all the politically unpopular policies it demands, is not in the selfinterest of governments to pursue in a common monetary union. Uncertainty is heightened as coordination becomes problematic since defections result in Pareto-inferior equilibria. As history has revealed, lacking sufficient punitive measures, the SGP cannot overcome this threat. With the original Pact, "penalties for persistent infringement were neither credible nor politically acceptable." ${ }^{114}$ Enforcement, therefore, needed to be improved in the aftermath of the Ecofin crisis.

This meant reforming the "corrective arm" of the Pact to accommodate the discretion afforded to Member States under the Lisbon strategy in accordance with the rules promoting fiscal discipline. The clarification and implementation of the EDP was the outcome of said proceedings. Council Regulation (EC) No 1056/05 replaces No 1467/97. Whether this reform will be effective in maintaining compliance is contestable. A common argument advanced by many observers submits that this change signals the dilution of the

${ }^{114}$ C.A.E. Goodhart, "Replacing the Stability and Growth Pact?" in Euroland and the World Economy: Global Player or Global Drag? ed. Jorg Bibow and Andrea Terzi (New York: Palgrave MacMillan, 2007), 136. 
Pact, thereby dulling, if not muzzling, its "bite."115 These sceptics are quickly reminded, however, that the remaining alternative - no Pact whatsoever - would place the euro area in an even more dubious position. Nevertheless, confidence is generated by faith in the organisational infrastructure and its performance since these help mitigate the uncertainties attributed to volatile political forces.

An ideational consensus, acknowledging the need for a fiscal framework, may still exist. Under uncertainty, however, "agents can have no conception as to what possible outcomes are likely, and hence what their interests in such a situation in fact are." Because these fiscal relations are highly unique, it is impossible to assign exact probability distributions to them. Thus, guarding ex-ante against adverse developments becomes more complicated, if not impossible, since one cannot forecast their contextual and temporal coordinates with any degree of precision. What we are left with, according to Beckert, are "the cognitive, structural and cultural mechanisms that agents rely upon when determining their actions." 117 My genealogical analysis takes these into account by demonstrating the discursive constitution of subjectivities, and thus interests, in terms of uncertainty.

Narratives, such as good times, and mechanisms like MTOs and the EDP help orientate EMU subjects by providing a framework for the "projectional interpretation" of their environment. ${ }^{118}$ As Connolly elaborates, this:

\footnotetext{
115 Bernard Winkler, "Stability and Growth: The Role of Monetary Policy and Other Policy Actors in EMU;" Philip Arestis and Malcolm Sawyer, "Macroeconomic Policy and the European Constitution," in Alternative Perspectives on Economic Policies in the European Union, ed. Philip Arestis and Malcolm Sawyer (New York: Palgrave MacMillan, 2006).

${ }^{116}$ Mark Blyth, Great Transformations: Economic Ideas and Institutional Changes in the Twentieth Century, 32.

${ }^{117}$ Jens Beckert, "What Is Sociological about Economic Sociology? Uncertainty and the Embeddedness of Economic Action," Theory and Society 25, no. 6 (1996): 814.

${ }^{118}$ William Connolly, "The Irony of Interpretation," in The Politics of Irony: Essays in Self-Betrayal, ed.

Daniel W. Conway and John E. Seery (New York: St. Martins, 1992), 145.
} 
proceeds by projecting ontological presumptions explicitly into detailed interpretations of actuality, acknowledging that its implicit projections surely exceed its explicit formulation of them and that its explicit formulation constructed relative to other identifiable positions - always exceeds its current capacity to demonstrate its truth. ${ }^{119}$

In other words, uncertainty, in the Knightian tradition, is not reducible to risk. The exactitude of action under uncertainty cannot be forecast in advance because it has yet to be determined. That is why discretion is so vital. Flexibility affords policy-makers a better opportunity to respond to the interpretation of the uncertain event. Otherwise, effective action would be hampered by the institutional inertia of systems whose premature devisal proves inadequate in dealing with that specific situation.

Rather than being fixed to a transcendental epicentre, fiscal relations are implicated in discourses as relational systems of meaning and power. Embedded in these, EMU subjects can overcome the collective action problem as these discursive practices supply the resources for coalition building. They "redefine existing interests under uncertainty and thereby redistribute the perception of existing political costs and benefits regarding alternative courses of action." ${ }^{120}$ Although Blyth is correct to assert that this can help alleviate the free-rider problem and foster greater cohesion among Member States, his is primarily a meta-theoretical argument. Recognising language as constitutive of social relations, he nevertheless fails to embed ideas within concrete practices of government. Huysmans warns against this tendency since it omits to analyse the political machinery and systems of power in which these ideas and discourses are implicated. ${ }^{121}$ That being said, Blyth does present a number of promising intellectual points of departure regarding

\footnotetext{
${ }^{119}$ Ibid, 145.

${ }^{120}$ Mark Blyth, Great Transformations: Economic Ideas and Institutional Changes in the Twentieth Century, 38.

${ }^{121}$ Jef Huysmans, The Politics of Insecurity: Fear, Migration and Asylum in the EU.
} 
government under uncertainty. His work elucidates how the difficulty of assigning probability values to outcomes can only compound the problem of effective multilateral surveillance in governmental regimes like EMU.

On the one hand, Coeure and Pisani-Ferry are correct to maintain that there is little in the way of concrete guidance pertaining to the implementation of the corrective arm. ${ }^{122}$ After all, irrespective of the reforms, EMU still resembles more of a political pledge than a mechanism of quasi-automatic sanctions. ${ }^{123}$ Automaticity requires the reproduction of an "objective" standard as a threshold against which to judge fiscal conduct. Even with the stricter SGP, punitive measures were never seriously entertained in 2003; especially since most countries failed to meet the convergence criteria upon adopting the euro. Should such a procedural facade be replicated when next tested, the integrity of the entire SGP would be gravely undermined, ineluctably triggering its collapse. Of course, in no way am I predetermining the inevitable doom awaiting the SGP. It is much too early to unequivocally pronounce judgement on the fate of the second manifestation of the Pact.

On the other hand, convergence and improvement in the fiscal performance of Member States is evident since the introduction of the euro. The number of Member States in excessive deficit has diminished since the 2005 reforms were introduced. One year on, five euro area members were subject to the EDP in the second quarter of 2006. A year later in 2007 only two remained. But by July 2008 there were none as the EDP was abrogated against all Member States except Hungary. ${ }^{124}$ Obviously, the market upswing in good

\footnotetext{
${ }^{122}$ Benoit Coeure and Jean Pisani-Ferry, "Fiscal Policy in EMU: Towards a Sustainability and Growth Pact," 598-617.

${ }^{123}$ Martin Heipertz and Amy Verdun, "The Dog that Would Never Bite? What We Can Learn from the Origins of the Stability and Growth Pact," 770.

${ }^{124}$ European Commission: DG for Economic and Financial Affairs, "Stability and Growth Pact: CountrySpecific Procedures," available from http://ec.europa.eu/economy_finance/sg_pact_fiscal_policy/excessive_ deficit9109_en.htm.
} 
times contributed to the upsurge in government revenues but several states, most notably France (2.9 percent deficit), remained on the borderline in precarious fiscal straits.

However, progress was being achieved and reflected in both budgetary consolidation and compliance with the procedural elements of the Pact. That is to say that its operation has been smooth without any major disturbances or conflicts.

Then on August 9, 2007, turbulence hit and soon prophesies of the "Second Great Depression" began to circulate. Although that verdict proved premature, all EU economies, aside from Poland, contracted. In the face of tremendous uncertainty, Europe has crawled out of recession posting a modest 0.4 percent growth in GDP during the third quarter of 2009; in large part thanks to the European Economic Recovery Plan (EERP). But this is no time for complacency. European policy-makers need to be especially cognisant of how they organise themselves and the form that any recovery will take. In today's precarious climate, extreme vigilance is more necessary than ever. Stimulus programmes and cheap credit must be used deployed effectively but prudently in order to avoid unbearable debt burdens or asset bubbles. Governments cannot be myopic and simply concern themselves with the immediate threat of a fragile economic recovery. Although "suspended" because of the "exceptional" circumstances, the SGP must be respected and treated seriously for it to be credible when the cycle turns. A large portion of that depends on how surveillance is practiced in reconciling an economic recovery with sustainability.

This means the Commission must judiciously monitor national accounts and propose ambitious, yet realistic, action plans for the Council to approve. The October 20, 2009 Ecofin Council has identified 2011 for implementing fiscal exit strategies; obviously contingent on evidence of a self-sustaining recovery. Fiscal consolidations will vary on 
budgetary predicament. For its part, on November 11, 2009, the Commission identified the existence of excessive deficits in 13 Member States. Laggards like Ireland (12.5 percent deficit in 2009) are expected to make greater concessions of 2 percent each year until 2014, while healthier economies, such as Germany, are required to cut 0.5 percent of GDP until 2013. Whether these targets are met is uncertain. What is becoming more evident is that caution entails devising an appropriate exit strategy within the auspices of the Pact. Joaquín Almunia, the Economic and Monetary Affairs Commissioner, echoes this sentiment, stating that:

We all agree on the need to design clear and credible exit strategies to reduce public deficits and debts, which have been dramatically increased by the crisis. The Stability and Growth Pact provides the anchor for such exit strategies through both the excessive deficit procedure and the Stability and Convergence Programmes that will be notified next January. ${ }^{125}$

The application of the SGP is not mutually exclusive from, but compatible with, continued government stimulus.

Keeping this in mind, this forthcoming section dissects the dissuasive matrix of government to illustrate this transition to uncertainty as a modality of rule. First, I introduce the procedural process by which the EDP is invoked. Possessing a good grasp of its mechanics, I then proceed with an analysis of the fundamental reforms that exemplify this novel form of government. How these forms of governance are shaping incentives towards national fiscal ownership, or the internalisation of self-regulation, and what systems of power are evident in this function is addressed. This encapsulates an interrogation of the multiple determinants of quality public finances and the assessment of effective action in

\footnotetext{
${ }^{125}$ European Commission: DG for Economic and Financial Affairs, Press Release, Commission Excessive Deficit Procedure Steps: The Stability and Growth Pact as the Anchor for Fiscal Exit Strategies, 11 November 2009, IP/09/1694 (Brussels).
} 
the revamped SGP. Concluding, I flush out how discretionary practice is transforming the nature of the political economy of fiscal surveillance in Europe.

\section{Excessive Deficit Procedure}

In the aftermath of 2003, a deficit bias remains that is ultimately unsustainable and a behaviour that the SGP has apparently failed to eradicate. The Commission itself acknowledges that "tensions have accumulated in the application of the SGP, leading to a loss of credibility and ownership and institutional uncertainty." ${ }^{2126}$ Painstaking as the reform process was, in the end, 'the 'hard letter' of Pact was transformed into 'soft' policy coordination," infusing a considerable degree of discretion, which fuels uncertainty, into the identification of breaches and the implementation of corrective instruments. ${ }^{127}$ "Oneoff" and "temporary measures" introduce more flexibility as they catalogue potential conditions that depart from the rationality of strict compliance with simple rules. More "sophisticated," the new EDP expands room for political judgement in setting deadlines and in considering what factors may influence its launch. Discretion is necessary to accommodate the growing programmatic belief that future oriented purview must be responsive to the heterogeneity of European political economy. As such, uncertainty is inscribing a particular meaning into the European fiscal landscape.

That long-term sustainability of public finances rests on the reduction of excessive governmental liabilities is commonsensical. However, the Commission, in publications such as the recent Sustainability Report, admits that the dilemma lies in properly

\footnotetext{
${ }^{126}$ European Commission, Strengthening Economic Governance and Clarifying the Implementation of the Stability and Growth Pact, COM (2004): 3

${ }^{127}$ Gaby Umbach and Wolfgang Wessels, "The Changing European Context of Economic and Monetary Union: 'Deepening', 'Widening', and Stability," 65.
} 
determining how to assemble the appropriate surveillance infrastructure to achieve this objective. Especially in times of deep market correction and any ensuing recovery:

the sustainability assessment is undertaken under larger than usual uncertainty. On the one hand, it is difficult to correctly judge the initial structural fiscal position in 2009. This is related to the uncertainty on the potential output and the output gap, but also on the way that tax revenue has been affected by the crisis, as well as on the durable or temporary nature of the support measures adopted by governments (original italics). ${ }^{128}$

Compounding this problem is that the EERP acts as a distorting mechanism. Stimulus has temporarily inflated budgetary liabilities, which "have not been fully filtered out of structural deficits," thus "the sustainability risk may have been overestimated." 129 Of course, underestimating the danger by failing to inject liquidity into the markets could have prolonged a more severe protracted recession. Again, subjective estimations need to supplement probabilistic measurements in the design of policy. Combined together, these prescriptive contingencies accentuate the internal control and operational difficulties facing EMU architects. To address them in the context of the Lisbon agenda, the Commission and the Council, along with the Eurogroup, have been persuaded to enhance their capacity to respond to any indeterminate future conditions. In effect, these are economic realities that they themselves are constructing through the governmental modality of uncertainty. A feedback loop is visible as this is an interpretative and interactive process whereby EMU subjects continuously negotiate how Member States should be assessed in terms of the vectors of uncertainty that they are assigned.

Together the focus on debt sustainability and the elimination of uniform MTOs, amongst others, have helped enhance the macroeconomic rationale underpinning the new

\footnotetext{
${ }^{128}$ European Commission, "Communication from the Commission to the European Parliament and the Council, Long-Term Sustainability of Public Finances for a Recovering Economy, COM (2009) 545/3 (2009). ${ }^{129}$ Ibid, 5.
} 
Pact. The hope is that these preventative arm provisions will assist in fostering compliance and thus hedge against the reproduction of an institutional crisis that could once again paralyse EMU. Of course, these ambitions will undoubtedly confront defiance as Member States pursue their own national agendas. This may be considered another "axiom" of EMU. Hence, the reforms have expanded the fiscal leeway granted to governments in the justification of excessive budgetary positions.

Not only does it satisfy firm political convictions, such as the clause exempting expenses incurred in the promotion of "European unification" designed to appease German demands that its costs of unification be recognised, but it also makes more macroeconomic sense. By shifting the focus to actual budgetary consolidation rather than nominal targets, the SGP has the potential to help Member States prudently manage their fiscal books. No longer is automatic punishment privileged at the expense of political realities. Now the "purpose of the excessive deficit procedure is to assist rather than punish, and therefore to provide incentives for Member States to pursue budgetary discipline, through enhanced surveillance, peer support and peer pressure. ${ }^{130}$ However, the Council reaffirms that a balance is necessary between automaticity, which endows the framework with credibility, and discretion, which accommodates uncertainty stemming from fiscal sovereignty.

Realistic deadlines and conditions are a step to resolving EMU's "inability to find a satisfactory way of formulating discretionary fiscal policy as an implementable rule and a set of practical institutions to support that rule." ${ }^{, 131}$ In terms of the latter, the EDP must

\footnotetext{
${ }^{130}$ Council of the EU, Brussels Spring European Council: Presidency Conclusions, 22 and 23 March 2005, 31.

${ }^{131}$ Stefan Collignon, "The Three Sources of Legitimacy for European Fiscal Policy," International Political Science Review 28, no. 2 (2007): 164.
} 
remain simple, transparent and equitable. ${ }^{132}$ The Commission is the institution mandated with identifying excessive deficits and preparing the report under Article 104(3). This is simply a reaffirmation of the status quo but is seen as necessary because it provides a clarified division of labour. Assessments are performed by the Commission, who has the right to "bark." It can even issue "policy advice" to the fiscal sinner, which is a broad, forward-looking tool not necessarily restricted to budgetary deviations. If the necessary corrective adjustments are not undertaken, the EDP is triggered.

The Commission adopts a Report, taking into account the newly exempted provisions under Article 104(2). The Economic and Financial Committee formulates an opinion on this report, which the Commission considers. Should an excessive deficit exist then the Commission addresses an opinion to the Council under Article 104(5). Upon deliberating its merits, the Council can initiate the correction of said deficit by issuing a recommendation to the profligate state in accordance with Article 104(7). These measures apply to all Member States but the following steps of the EDP are reserved for those inside the euro area. In the case where the recommendation is not respected, the state is issued another notice under Article 104(9) and only then may be open to the imposition of sanctions foreseen in Article 104(11). Here surveillance is more stringent; though by no means is censure imminent.

Ostensibly, there is a tremendous amount of discretion available to both the Commission and the Council in how they render a verdict on the existence of excessive deficits and their correction. Greater latitude in the interpretation of whether such a condition exists is only reinforced by the renewed round of recommendations and the slew

\footnotetext{
${ }^{132}$ Council of the EU, Brussels Spring European Council: Presidency Conclusions, 22 and 23 March 2005, 31.
} 
of exceptions to the rules included in the 2005 SGP reforms. These exemptions are deliberately reformulated to address the demands of national fiscal sovereignty and the contingent and contextual character of fiscal relations. Less automatic and more conditional on subjective estimations, the revised Pact appears to privilege discretion over rules.

However, there is an underlying danger. Softening the rules in this fashion may "facilitate a more lax implementation, which could imply higher and more protracted deficits."133 Moreover, as Schelkle posits, quasi-automatism of this kind may actually create moral hazard since the Council is composed of those simultaneously executing the statutes and subject to them. ${ }^{134}$ Conceptual inconsistencies have not been resolved but quite possibly exacerbated by the (re)politicisation of the SGP. After all, it is the Council that has the power to ultimately override any decision. Whether it will in fact ever reach that boiling point given the considerable leniency in the identification, interpretation and application of the Pact is suspect.

In this EDP redesign, the assessment of what constitutes as "effective action" is clarified to encompass factors outside the control of the government and those considered under its control. Fluctuations in interest-rates or tax elasticities comprise the first category. The second draws attention to the actual introduction of corrective measures and budgetary execution. By delineating the range of variables that need to be accounted for in determining the performance of adjustment, budgetary surveillance is now equipped with a new, major innovation.

\footnotetext{
${ }^{133}$ Lucas Papademos, "The Political Economy of the Reformed Stability and Growth Pact: Implications for Fiscal and Monetary Policy" (Speech given at the Conference "The ECB and Its Watchers VII," Frankfurt, Germany, June 3, 2005).

${ }^{134}$ Waltraud Schelkle, "The Political Economy of Fiscal Policy Co-ordination in EMU: From Disciplinarian Device to Insurance Arrangement," Journal of Common Market Studies 43, no. 2 (2005): 385.
} 
In its diluted form, the SGP privileges circumstantial governance. Of course, this entails engineering the EMU in such a manner as to instill confidence in the fiscal regime and promote consolidation, rather than simply finding evasive schemes that abdicate Member States of their responsibilities. New revisions to the EDP may make that increasingly difficult as more factors are considered in the appraisal. To begin with, the concept of "exceptional and temporary" excess over the reference value is widened. To be considered exceptional, "the excess has to result from an unusual event outside the control of the Member State and with a major impact on the financial position of the general government, or it has to result from a severe economic downturn," which is conventionally defined as at least a 2 percent decline in real GDP. ${ }^{135}$ Not surprisingly, the current "great recession" qualifies for this designation. Euro area budget deficits have contracted by 6.4 percent of GDP in 2009.

With the outlook for 2010 deteriorating to an aggregate deficit of 6.9 percent, Member States also have other options available at their disposal to help them escape uncomfortable budgetary consolidations. Unacceptably restrictive in the original Pact, "severe economic downturn" has been redefined to encompass essentially all periods of negative growth and protracted periods of weak annual GDP growth relative to its potential. ${ }^{136}$ The only stipulation is that the ratio must remain close to the nominal value and be temporary. Unfortunately, this temporal constraint is quite vague since "temporary" is understood as "the end of the unusual event or the severe economic downturn." "137 Since

\footnotetext{
${ }^{135}$ Council of the EU, Code of Conduct, 6.

${ }^{136}$ Council of the EU, Council Regulation (EC) No 1056/2005: Amending Regulation (EC) No 1467/97 on Speeding Up and Clarifying the Implementation of the Excessive Deficit Procedure, 7.7.2005, EC (2005), 5.

${ }^{137}$ Council of the EU, Code of Conduct, 6 .
} 
it is imaginable that these unique contingencies may persist in some form or other over the business cycle, temporary may in fact prove to be quite a long time.

Again, this is another example of how time is appropriated to suit the interests of individual EMU subjects. No longer linear across contexts, time becomes monetised through the EDP. As it manipulates the timing and tempo of consolidation, the EDP assigns it a price representing the cost of excess. National electoral calendars and their political cycles overlap with business cycles, potentially interfering with government efforts at structural reform. Agenda 2010 exacerbated Germany's fiscal position as the pace of labour-market and welfare-state reforms accelerated. In turn, whether particular Member States are sanctioned or not is determined by how uncertainty is deployed to recode the sequence of their timeframes which determine attempts at compliance. Since growth rates vary, the EDP is charged with processing time at different speeds rather than upholding one standard against which all are assessed. In these evaluations, time is assigned a future value which corresponds to its differentiated rationalisations.

To complement the refocus on debt and long-term sustainability, where the decline in the rate of the debt ratio should be "sufficiently diminishing and approaching the reference value at a satisfactory pace," the initiation and execution of the EDP have been modified. ${ }^{138}$ More lenient in scope, the Council is provided with an extra month to adopt a decision under Article 104(6). Extending this term to four months is intended to enhance the quality of recommendations by making them more reflective of the heterogeneous composition of national markets. Upon being issued a recommendation to remedy an excessive deficit under Article 104(7), governments now have six months to take effective

\footnotetext{
${ }^{138}$ Council of the EU, Brussels Spring European Council: Presidency Conclusions, 22 and 23 March 2005, 17.
} 
action. Granted more time, governments are arguably in a better position to frame the necessary adjustment path within their own broader national budgetary programmes while being actively encouraged to align those with Community objectives. Embedding corrective measures in the national fiscal landscape can promote concrete structural reforms rather than mere temporary band-aids. Typically, as a rule, the deadline for the correction should be one year after its identification, which translates into the second year after its occurrence.

Should a violation be identified and recommendation made, a minimum fiscal adjustment of 0.5 percent of GDP per annum is required. This may be massaged if attempts are frustrated by adverse circumstances. Public expenditure is often intertemporal (i.e. education, pensions), which was not recognised under the original SGP's annual accounting scheme. Now these factors are identified in determining culpability. Whether Cafruny and Ryner are correct to contend that such discretionary clauses will in fact invite arbitrary abuses and irresponsible interpretations still remains to be seen. ${ }^{139}$ If abuse becomes rampant, it will only amplify the reputation uncertainty surrounding the Pact and attenuate its effective operation. Whatever the indeterminate future holds, however, for the moment the legitimisation and power in the amended EDP are increasingly in the province of more qualitative practices and soft modes of governance.

To ensure its escape from potential punitive measures, in spite of breaching the diluted regulations enumerated above, a further clause was included which virtually gutted the Pact of its corrective authority. "All other relevant factors" must be taken into account for the EDP to be held in abeyance. Article 104(3) of the new Pact stipulates that:

due consideration will be given to any other factors, which in the opinion of

${ }^{139}$ Alan W. Cafruny and J. Magnus Ryner, Europe at Bay: In the Shadow of US Hegemony, 34. 
the Member State concerned are relevant in order to comprehensively assess in qualitative terms the excess over the reference value. In that context, special consideration will be given to budgetary efforts towards increasing, or maintaining at a high level financial contributions to fostering international solidarity and to achieving European policy goals, notably the unification of Europe if it has a detrimental effect on the growth and fiscal burden of a Member State (added italics). ${ }^{140}$

No redefinition of the Maastricht reference values is permitted. But dodging their enforcement appears to be entirely acceptable. What this essentially does is raise the reference target to whatever value, in practice, prevails enough to satisfy the exemption criteria and thus be tolerated. Of course, as Eijffinger argues, such externalities may be mitigated should Member States take their fiscal responsibilities seriously and behave prudently in good times. ${ }^{141}$ This is the ambition so many europhiles wish for. Problematic, however, is the fact that while the deficit threshold on the corrective side remains at 3 percent, it is differentiated on the preventative arm and calculated in relation to the debt ratio and the rate of structural growth. Divorced, these incongruities may amplify antagonisms as Member States find their heterogeneity at odds with the dissuasive elements of the Pact.

Already we can foresee this potentially happening in the case of Italy. In its most recent 2009 opinion, the Commission argues that "relevant factors" are not admissible because Italy does not satisfy the double conditions of temporality and closeness to the nominal value. This may well be disputed when the Council meets in December 2009. If the Commission is rebuked, thereby sanctioning such elusive conduct, the revamped SGP helps fiscal profligate countries like as Italy "avoid reductions in public debt, thereby

\footnotetext{
${ }^{140}$ Council of the EU, Council Regulation (EC) No 1056/2005: Amending Regulation (EC) No 1467/97 on Speeding Up and Clarifying the Implementation of the Excessive Deficit Procedure, Article 104(3).

${ }^{141}$ Sylvester Eijffinger, "On a Reformed Stability and Growth Pact," Intereconomics May/June (2005): 145.
} 
prolonging its own fiscal crisis even as its industries become less competitive." ${ }^{142}$ In effect, rather than curbing excessive deficits, these discretionary clauses may invite abuses and uncertainty as they delay the necessary reforms that would restore the health of ailing economies. Conversely, overtly constraining interpretations of the statutes have the potential to choke off any recovery.

Clarifying what constitutes as relevant and exceptional - otherwise referred to as "special circumstances" in the original SGP - is a move away from simplicity to a more nuanced approach to governing fiscal relations in Europe. It addresses the charge that "the imposition of a ceiling percentage of GDP on the public deficits of Member States inevitably causes a procyclical orientation of fiscal policies" by augmenting what is permissible with the infusion of discretionary modes of governance. ${ }^{143}$ But irrespective of the poor optics associated with the laxity and evasiveness of these reforms, the Council reaffirms the temporality of these conditional exemptions. Implicit in this recognition is that time can be a contributing factor to the aggregation of excess. After all, these clauses are not designed as "get out of jail cards" but as methods to help accommodate and eventually improve the precarious budgetary positions of Member States. If governments avoid implementing the necessary fiscal consolidation programmes in an expedient fashion then the likelihood of their public finances deteriorating grows. As it does, time contributes to the amplification of uncertainty surrounding budgetary operations since it exposes Member States to the threat of accumulating further excessive deficits. Reputations suffer as any quick restitution appears doubtful. This problem is compounded by procedural repetition.

\footnotetext{
${ }^{142}$ Alan W. Cafruny and J. Magnus Ryner, Europe at Bay: In the Shadow of US Hegemony, 69.

${ }^{143}$ Jean-Paul Fitoussi and Jacques Le Cacheux, Report on the State of the European Union, Volume 2: Reforming the European Union, 27.
} 
On the one hand, the consensus is that pro-cyclicality must be deterred. On the other hand, there is a disjuncture between what sounds plausible in theory and how it is actually rendered into practice. With the introduction of these exceptional and other relevant factors, it is possible to repeat the steps of the EDP if failure to comply may be attributed "to unexpected adverse economic events with a considerable impact on the budget." ${ }^{\prime 14}$ Special circumstances, therefore, have the potential of delaying adjustments into the third year subsequent to an occurrence. Frictions over this notion of exaggerated lags provoked the proposition of a "minimum fiscal effort," which would see a consolidation of the structural balance by a minimum of 0.5 percent of GDP. ${ }^{145}$ Rather than being obligatory on the corrective arm, this became the objective for adjustment towards the differentiated MTOs. Ostensibly, the Ecofin crisis engendered revisions that seem to preclude any direct intrusion into the fiscal affairs of Member States in favour of vague, precautionary mechanisms. Whether this will stand the test of time or be marred by it remains to be seen.

Such questions preoccupy both the Commission and the ECB. In their shared opinion, shying away from serious budgetary consolidation will only aggravate relations with these other EMU institutions. But there is sign that real expectations are already diverging. Even in today's tenuous recovery, Jean-Claude Trichet is convinced that, by 2011 at the latest, Member States must "engage in recovery programs that do significantly more than $0.5 \%$ of GDP in structural terms of improvement every year. And in many cases

\footnotetext{
${ }^{144}$ European Commission: DG for Economic and Financial Affairs, European Economy: Public Finances in EMU 2006, 107.

${ }^{145}$ Martin Heipertz and Amy Verdun, "The Dog that Would Never Bite? Origins, Crisis and Reform of Europe's Stability and Growth Pact," 124.
} 
more than $1 \% . " 146$ For this purpose, the ECB "expects the Commission to make the analysis as rigorously as possible" and is prepared "to back its rigorous implementation of the Pact." ${ }^{, 147}$ A unified front of this sort is not surprising. In the end, the Commission seeks to control budgetary profligacy for the sake of a sound monetary union. Of course, neither is the lukewarm reception that an "over ambitious" agenda is receiving from Member States in dire straits, most notably Spain and France.

Convincing them to respect even the agreed upon minimum of 0.5 percent may undoubtedly prove an uphill battle for the ECB and Commission, especially when tolerance for excess remains expansive. Squabbles and territorial fights can only damage the reputation of certain actors and the credibility of the entire framework. Political capital must be deployed to reinforce the reforms if they are to be successful. Such demonstrations must begin as soon as warranted. Otherwise, delays will only foster suspicions about the credibility and efficacy of the EDP, thereby contributing to more uncertainty. This means transforming the EDP into a strong policy tool which Ecofin is not afraid to use.

One potential method, aligned with the focus on long-term sustainability, articulated by good times, is to activate the debt trigger for the EDP. Given that the reduction of debt below 60 percent of GDP is touted as essential for the success of the Pact, Ecofin will formulate recommendations in its opinion of submitted SCPs. According to the 2005 Council Report, these evaluations will be made in "qualitative terms" and take into account macroeconomic conditions and debt dynamics together with debt management

\footnotetext{
${ }^{146}$ Jean-Claude Trichet, interview by Cor de Horde and Klaas Broekhuizen, Het Financieele Dagblad, The Netherlands, 16 November 2009.

${ }^{147}$ Ibid.
} 
strategies. ${ }^{148}$ Debt management strategies speak of the need to have effective internal control. But the condition that is attached to this process, which removes it from a purely quantitative analysis, is that debt ratios are "sufficiently diminishing...at a satisfactory pace." How temporality is assessed depends on the critical faculties of Ecofin members. It is a judgement call on how well time is being utilised by Member States. Quantitative methods can assist in the assessments but they cannot make the decision.

Unfortunately, these modifications to the EDP ignore the conceptual inconsistency implicit in fiscal surveillance. Rather than being erased, it has been further entrenched by the revamped exceptional and temporary measures. Additional exemptions merely motivate Member States to locate the appropriate loophole permitting them to escape sanctions. Thus, the paradox is that hope lies with the very technology that has the potential to subvert the entire framework. Any tensions produced by the antagonism between the programmatic and operational aspects of fiscal relations are intended to be defused through the discretionary measures that may contribute to them. It is not difficult to understand how this precarious dynamic only fosters a heightened sense of uncertainty surrounding the management of budgetary relations. Whether in the long-term this can help or harm the SGP is contestable. For the moment, it may help address any contentious issues as they arise before these flare up into impassable obstacles that jeopardise EMU.

\subsection{Retracing the Terrain of Government}

Through the deconstructive/reconstructive analytic, a shift in the rationality underpinning the amended Pact is rendered visible. Dissecting the EDP reveals a distinction in how EMU

\footnotetext{
${ }^{148}$ Council of the EU, Improving the Implementation of the Stability and Growth Pact (Report to the European Council, 7423/05, Brussels, 2005).
} 
policy-makers frame the SGP problematic when compared with the original version. In the case of an "unexpected," adverse economic shock, the process may be repeated as the deadline is revised and extended beyond the original date stipulated by the Council in its recommendations under Article 104(7) or Article 104(9). To qualify for this programme, however, the Member State must be pursuing effective action in compliance with the initial recommendation. Yet, what is significant to note here is the formal distinction that is being made between statistically unpredictable crises, or uncertainty, and policy errors, often resulting from poor risk management. Only the former is considered as a justifiable cause for re-evaluating set deadlines. ${ }^{149}$ The latter is simply a case of inadequate quantitative calculations and modelling. Unexpected events evade aggregation as a calculable probability. As such, they demand alternative modes of governance to manage them. Uncertainty is qualitatively different than risk because in these situations EMU subjects are prevented from assigning a probability to an outcome since they have no basis upon which to base such an estimate. They cannot correctly know their interests prior to the actual event because it is "so entirely unique that there are no other or not a sufficient number to make it possible to tabulate enough like it to form any inference of value about any real probability in the case we are interested in." ${ }^{150}$ In this chapter, I have argued that, in such circumstances, assigning a weighted value as a probability would suggest that it is possible to forecast unusuality with a degree of precision and thus be cognisant of its beginning, conclusion, and severity. If this knowledge was statistically predictable, Member States would simply have to unearth this repeating figure and include it in their

\footnotetext{
${ }^{149}$ European Commission: DG for Economic and Financial Affairs, European Economy: Public Finances in EMU 2006, 107.

${ }^{150}$ Frank Knight, quoted in Peter Bernstein, Against the Gods: The Remarkable Story of Risk (New York: Wiley, 1998), 221.
} 
MTOs. Since Member States cannot accurately forecast how to avoid excessive deficits, the frequency with which they would flaunt the statutes needs to be controlled. Hence, the various Commission bodies and Ecofin revised how excessive deficits are monitored, communicated and eventually corrected.

Problematising EMU through an analytics of government reveals that flexibility is of utmost importance in managing these uncertain relationships. In such an unstructured environment, like this fiscal-monetary space, which fails to reproduce itself at regular intervals, a uniformly collectivised approach is virtually impossible. Thus, harmonisation is being abandoned in favour of modifications to both the preventative and the corrective arms of Pact, where the Council and Commission dispose considerable discretion in monitoring compliance. Not only are fiscal relations indicative of economic activity under uncertainty but these new SGP reforms simultaneously amplify its resonance by framing these relations through contingency; thereby cementing an organisational infrastructure that contributes to its perception.

Governmentality equips us with the necessary analytical tools to understand the changing rationality underpinning these technologies. Deconstructing this assemblage, we notice how the propensity towards failure expands to include a more subjective estimation than previously visible. Not only is this apparent in the dominant narrative - good times deployed to manage latent profligate tendencies but it is reinforced by being embedded in the organisational apparatus designed to mitigate these. In the process, the government through uncertainty constructs new realities where long-term sustainability is reconciled with national economic growth. The Lisbon strategy for jobs and growth is the driving catalyst behind this endeavour. 
Since there is no exogenous reality outside of the discursive constitution of EMU to be measured and quantified, the Lisbonisation of fiscal governance is fraught with contestation. EMU interests and identities are endogenous as they are constructed through the social practice of negotiating the very regulatory apparatus of which they are objects. Mediated through this dialectic between expertise and politics, the leverage of uncertainty seeks to modulate EMU subjects into compliance in the effort to balance debt sustainability with fiscal stabilisation. Discretion broadens the scope of this practice as it increases their susceptibility to an assortment of political forces adhering to their own unique understanding of the normalcy and utility of time.

The following chapter wrestles with how the discursive practices enumerated above work to define the prevailing notions of normalcy underlying the SGP. Uncertainty invites competing interpretations of normality, which are fundamental to creating specific EMU subjectivities. This performative dimension can be noticed in fields outside of fiscal and monetary politics. Two of these will be introduced to help document the proliferation of some of narratives and governmental modalities discussed above. Situating these in broader field of surveillance practices demonstrates the limits of quantification and the reabsorption of expertise into the political domain. 


\section{Chapter 5 Contesting the Template of Normalcy}

Contestable and heteromorphic, the relationship between risk and uncertainty creates new geographies of power where the programmatic and operational dimensions of European fiscal relations play out. With the 2005 SGP reforms, however, we are witnessing a discursive shift that formally recognises an analytical and governmental distinction between risk and uncertainty and entrenches the latter within the budgetary surveillance infrastructure. This rearticulation is validating new expressions of expertise by making previously immune forms, grounded in risk, susceptible to social and political forces. Such is the case because the SGP crisis revealed that probability distributions cannot be quantified to indicate and evaluate performance under uncertainty. Reigning statistical and econometric models have not been able to account for the contradictions and exceptions which have destabilised EMU the most. As the messy world of politics infringes upon what has largely been a depoliticised realm of risk management, critical judgement and personalistic factors become more paramount in appraising fiscal conduct and devising appropriate strategies to correct excessive deficits. How this dialectical relationship unfolds has a profound effect on what is sanctioned as a "normal" European budgetary practice. After all, the restitution of the fiscal framework is about recovering some semblance of normalcy which will hopefully foster compliance and eventual convergence.

As I have argued, my search is not for divergent ontological properties that separate an EMU risk from an EMU uncertainty. Rather these governmental categories are "ways in which the real is imagined to be by specific regimes of government." ${ }^{11}$ New corrective measures point to how precautionary efforts target the variability and diversity implicit in

\footnotetext{
'Pat O'Malley, Risk, Uncertainty and Government (Portland: The Glasshouse Press, 2004), 15.
} 
fiscal relations by continuously monitoring the dispersed sites where deviation can occur. With the inclusion of the differentiated MTOs or "exceptional" EDP clauses, the spatial fabrication of EMU is endowed with its own temporality and density.

This management of time, at a plurality of sites, produces temporary stabilisations where control over an indeterminate future is exercised in the attempt to curtail abnormal profligate behaviour. But what constitutes as normal effective action is increasingly an individuating calculation that recognises the flux of uncertainty as it pertains to specific budgetary positions at certain intervals in time. It addresses the unique circumstances facing particular Member States, which are unexpected, by framing these problems through a new modality of government. In the process, the leverage of control, crystallised in narratives like good times - as a precursor for national fiscal ownership - is exerted through these novel technologies. It endows the SGP with a materiality and power to construct normalcy as a template against which modes of governance are evaluated. This is a performative practice that "stabilizes over time to produce the effect of boundary, fixity and surface" known as EMU (original italics). ${ }^{2}$

To grasp how uncertainty generates certain state effects, this chapter first introduces how normalcy is imagined in EMU. As a boundary object, it works to moderate governmental programmes designed to balance debt sustainability and fiscal stabilisation by defining the conditions of possibility. These limits are established through the strategic deployment of uncertainty as both an analytical and governmental category. In turn, normalcy informs what is considered permissible and censures unacceptable deviation. Mutually constitutive, normalcy is continuously reinventing the threshold against which governmental modalities are judged. They are not homogenised into one uniform system

\footnotetext{
${ }^{2}$ Judith Butler, Bodies That Matter: On the Discursive Limits of "Sex" (New York: Routledge, 1993), 12.
} 
applicable across the entire EMU plane. Nor do they adhere to one single notion of a normative ideal that can be extrapolated across of all Europe. Rather EMU is the terrain where competing interpretations of normality are articulated and validated. The discursive practices enumerated in the preceding chapter are the result of this effort.

Next, we come to terms with this struggle for visibility through the deconstructive/reconstructive ethos explicit in the governmentality approach. It supplies us with the necessary analytical tools to problematise how these variegated notions of normalcy inform the continuous construction of this emerging fiscal-monetary space. Normalcy presupposes and creates alterity. Alterity, on the other hand, is fundamental to the constitutive force of performativity. A notion of "otherness" is integral the politics of limits. It assigns a normative value to conduct - albeit contested and indeterminate - which may be deployed to promote compliance and eventual convergence. Such is the case because representation is the dominant logic of discursive power. A discussion of how power flows in the delivery of this managerial capacity, to shape EMU subjectivities, comprises this second section. Analysing the performativity of practice helps illustrate the contradictory nature of organisational (programmatic) and political life (operational). At once, Member States are subjects and objects of government. Variegated notions of normalcy help alleviate some of the tensions this configuration produces.

Multilateral surveillance techniques that "judge" the state are not new to IR. In fact, the discourse of "good governance" is common in the normalisation of governments into alignment with neoliberal dictates. Privatisation and/or corporatisation, central to this orthodoxy, are often identified with these governmental projects. The new Pact may be seen as contributing to this neoliberal programme by targeting the entrepreneurial capacity 
of individual EMU subjects as self-regulating actors. Free-market virtues are extolled and uncertainty is perceived as a "profitable" opportunity to be exploited. Again, politicians and officials are increasingly confronted with the endogenous responsibility of managing their own uncertainty rather than relying on collectivising measures which pool risks. Before concluding, I consider the resonance of some of these subthemes in the international campaign against public corruption. Such an exposition demonstrates the penetration of a governmental rationality privileging the internalisation of self-regulation in the broader field of state surveillance.

\subsection{Variations of Normalcy}

Normalcy is at the heart in the representation what is reasonable and right. Ultimately, close cooperation leading to convergence is the objective underpinning the entire EMU. ${ }^{3}$ From the "convergence criteria" enshrined in the Maastricht Treaty (1992) to the SGP (1997) itself to the launch of the monetary union (1999) and common currency (2002), an ideational consensus about what "normal/good performance" entails has been at the heart of regulating this emerging governmental regime. Experts, housed in institutions such as the Bundesbank and the ECB, equipped with a technical knowledge of monetary economics, have been influential in perpetuating the monetarist model and its dominant disciplinary discourse of "sound money and finance."4 That is until this prevailing normality was undermined by the SGP crisis in 2003 and its ideological consensus disturbed.

\footnotetext{
${ }^{3}$ Martin Heipertz and Amy Verdun, "The Dog that Would Never Bite? What We Can Learn from the Origins of the Stability and Growth Pact," Journal of European Public Policy 11, no. 5 (2004).

${ }^{4}$ Kenneth Dyson, The Politics of the Euro-Zone (New York: Oxford University Press, 2000).
} 
Whereas with the original Pact this constellation of "truths" was primarily governed through risk and perceived as the expression of pre-existing socio-economic forms, the revised SGP opens up new possibilities for thinking about what is considered normal and how to achieve it. Uncertainty enables subjects to develop the conditions that define what acceptable fiscal profligacy actually means and the solutions geared to remedy it, within a "strained space" of modulated discretion, which is more delimiting under modes of risk. This transforms how surveillance is practiced in EMU. It induces further fragmentation of the fiscal landscape, which only aggravates the de facto policy conflict of locating and coordinating the appropriate mix of economic and monetary initiatives.

Earlier in the dissertation, I noted that competing theoretical positions consistently revert to normative claims about EMU in their efforts to establish a standard by which to judge the SGP crisis. The doctrine of normalcy has proven irresistible as it allows for a certain condition to be labelled as "normal" whereas another is deemed "irregular" and thus erroneous. Any deviation from the normal state threatens ambitions of convergence and demands that corrective measures be undertaken as it implies moving away from the right course of action. Logically this sounds like a truism but normality is a discursive invention with a history of its own. As an idea, it has become firmly embedded within our social mentality and institutionalised in our structures.

Part of the reason is that the pragmatic discourse of moral normalcy has become interlaced, and even synonymous, with positivism, which has become commensurate with authentic knowledge in modern societies. Comte was one of the first to acknowledge this relationship, stating that:

the positive spirit is the only possible basis for a resolution of the intellectual and moral anarchy that above all characterizes the great crisis of our time... 
The positive school was gradually prepared, during the revolutionary struggle of the past three centuries, to constitute as much as is possible the true normal state of all the classes and elements. ${ }^{5}$

Henceforth, normalcy has been incorporated into virtually every discipline as the basis for classification and organisation. Arguably, nowhere is this more visible than in the area of monetary economics.

Echoing Hacking, normalcy is a social invention that is appropriated in a specific fashion to serve particular interests. ${ }^{6}$ First, we need to understand that although normalcy is construed as a target of governance, and good times/national fiscal ownership as its vehicle, the spatial and temporal variability of EMU impedes the realisation of any such single, applicable notion of normalcy. The uncertainty implicit in variable and diverse fiscal conduct frustrates attempts at discerning an optimal common strategy. ${ }^{7}$ What is considered "normal" for one Member State may spell disaster for its neighbour. Low interest rates were appropriate for certain economies, but fuelled the property bubbles witnessed in Spain and Ireland. Hence, differentiated approaches may yield better outcomes in the restitution of budgetary positions as governments cope with asymmetric shocks. Harmonisation has been discounted.

Whether the relaxation of the SGP proves so extensive as to virtually eliminate any semblance of commonality among Member States, upon which a broader EMU normality may be based, is difficult to determine at this point in time. Splintering is a concern but one that is overshadowed by the threat of immediate EMU disintegration. Nevertheless, deciphering these types of puzzles is outside the scope of this dissertation. My purposes lie elsewhere. I am more concerned with understanding how the government through

\footnotetext{
${ }^{5}$ Auguste Comte, Discourse on the Positive Spirit (Paris, 1844), 55.

${ }^{6}$ Ian Hacking, The Taming of Chance (New York: Cambridge University Press, 1990).

${ }^{7}$ John Maynard Keynes, Treatise on Probability (London: MacMillan, 1921, AMS Press Reprint, 1979).
} 
uncertainty signals an alternative approach to governing fiscal relations which welcomes alterity in the promotion of shared Community ambitions. Obviously, at first glance, this appears like an oxymoron doomed to fail. Upon closer examination, however, a sense of referentiality, around multiple notions of normalcy, may be established through the strategic deployment of uncertainty as a governmental strategy designed in accordance with the Pact. Yes it may be extremely fragile and tenuous. But, at present, it is the best course of action available in the ongoing quest to reconcile the often conflicting goals of fiscal stabilisation and debt sustainability.

Given the implausibility of complete uniformity in EMU, the utility of normalcy is cast into doubt. How can one single normative average be obtained in an environment with ever shifting parameters and unique exigencies? It seems implausible and that is why the EU abandoned its quest for standardisation and the harmonisation of budgetary policy. While there has been a visible convergence in growth rates since the introduction of the euro, business cycle synchronisation remains divergent. Wide degrees of variation in economic cycles pose a dilemma for the implementation and sustainability of a common monetary policy. ECB policy has dissimilar effects on fiscal initiatives. Again, we are reminded of the recent asset bubbles in Spain and Ireland. Hence, the architects of EMU are moving away from attempts to govern as if European economies are synchronised. Country-specific targets, notably those pertaining to the sustainability of public finances, reflect this change in economic rationale, leading to the replacement of the uniform requirement of CTBOIS with new methodologically clarified MTOs.

Covariance, however nominal, is being observed, especially as it pertains to domestic reform in the areas of fiscal, financial and labour-market policy. Although 
yielding neither a uniform pattern nor "simple clusters," Dyson concludes that the contingency underlying economic and monetary integration in Europe is producing "a paradoxical combination of clustering with crosscutting patterns and varying degrees of weakness of 'fit' of states to clusters." Conceptualised as a "kaleidoscope of patterns," our attention is drawn to the spatial-temporal variability implicit in the relationship between the euro and states.

Dyson submits that "bottom-up" processes are responsible for signs of clustered convergence. Most visible is the "Deutsche-Mark Zone," comprising of Germany, Austria, Belgium, the Netherlands, Luxembourg, and France. On the opposite end of the spectrum are the "Mediterranean" countries of Greece, Italy, and Portugal. ${ }^{9}$ Each of these clusters is developing similarities that bind them together and can potentially be exploited to formulate an official platform promoting coordination. Obviously, as I have argued, the heterogeneity underpinning European political economy defies any strict classification. It is through this variegation that the fragility in the alignment of the euro area actually becomes noticeable. But if common ground exists in these early, fragmented stages of EMU, where Member States subscribe to competing visions of normalcy, it is not absurd to consider that closer convergence and overlap in fiscal relations are attainable future goals. Fiscal federalism is not the stated objective. The SGP just needs to promote a sufficient amount of convergence to sustain and facilitate a credible and effective common monetary policy.

For example, Italy, a well documented profligate laggard, has managed to rein in its fiscal liabilities during this credit crisis relatively better than traditionally more

\footnotetext{
${ }^{8}$ Kenneth Dyson, "European States and the Euro Area: Clustering and Covariance in Patterns of Change," in The Euro at 10: Europeanization, Power, and Convergence, ed. Kenneth Dyson (New York: Oxford University Press, 2008), 382.

${ }^{9}$ Ibid, 381.
} 
responsible Member States. A projected exit strategy of 0.5 percent of GDP is equal to that of Germany. But what separates them is that the Commission is actually convinced that Italy's larger deficit of 5.3 percent of GDP can be contained by 2012; a year sooner than Germany's excess of 3.4 percent. Comparisons with deeply ravaged economies, such as the UK (12.1 percent of GDP) or Ireland (12.5 percent of GDP) - engines of growth for a decade - are perceived as almost comical. Though have the tables indeed turned?

Well, one is inclined to be incredulous of any substantive change. Italy's deepseated structural problems contributed to a cumulative drop of 6.5 percent of real GDP leading up to the first two quarters of 2009; on par with Germany but considerably greater than other euro area members. ${ }^{10}$ Its budgetary consolidation is primarily due to a lack of any real fiscal stimulus and to transferring the costs of the crisis onto the most vulnerable in society. More troubling is Italy's climbing public debt, which is projected to hit 118 percent by $2011 .{ }^{11}$ Yet there are signs of improvement, which, if properly managed through the new Pact, can pave the road to a more permanent pattern of convergence.

A thought-provoking analysis, Dyson's kaleidoscope approach entices us to rethink how we study EMU. Given this promising intellectual point of departure, which pre-empts the recognition of EMU as an economic construction in process, the discursive constitution of this emerging fiscal-monetary space is surprisingly underdeveloped. A critical engagement with the discourses he references is often lacking. That said, the concept of a kaleidoscope itself is useful in helping us transcend conventional "narratives of integration"

\footnotetext{
${ }^{10}$ European Commission: DG for Economic and Financial Affairs, European Economic Forecasts- Autumn 2009 (DG EcFin, 2009); available at http://ec.europa.eu/economy_finance/publications/publication1 6055_en.pdf.

${ }^{11}$ Ibid.
} 
which "presuppose a purposive form of institutionalization leading to a Euro-polity."12 Without a principal point of reference around which politico-economic relations coalesce, the dominance of a single normative frame of reference is disrupted. This opens up room to contemplate how variegated notions of normalcy can be mobilised to achieve Community compliance.

\subsection{Performative Generations}

Part of the challenge is devising acceptable forms of normalcy that enhance national fiscal ownership but do not stymie the forces of convergence across the eurozone. Budgetary surveillance must cope with what is an ever mutable communicative space in the effort to improve the sustainability and quality of public finances. A social and cultural domain, the boundaries of EMU are produced and renegotiated by the discursive and practical aspects of political power, which are both endogenous and exogenous to this space. EU measures "at restoring confidence and a return to growth" are provoking the overlap of Europe's political and technocratic landscapes. ${ }^{13}$ This only complicates the task of arriving at a consensual definition of normal fiscal conduct that can be codified without being easily usurped.

To a large extent, this movement is driven by the very the economists and forecasters that traditionally have devalued these non-quantitative approaches, such as emotional intelligence or hunches, to governing the economy. Knowledge that these EFC or EPC experts have "normally repressed, subordinated, and considered slightly illicit" is now being embraced in the constitution of conventions, which render states susceptible to

\footnotetext{
${ }^{12}$ Chris Rumford, Cosmopolitan Spaces: Europe, Globalization, Theory (New York: Routledge, 2008), 23.

${ }^{13}$ Council of the EU, Press Release, $2919^{\text {th }}$ Council Meeting, Economic and Financial Committee, 20 January 2009, 5196/09 (Press 9) (Brussels, 2009), 8.
} 
intervention. ${ }^{14}$ Uncertainty is reconfiguring how we come to recognise the "state" by assigning it properties. Diversity in design, with all the flexibility it affords, simply expands the available topology of EMU.

Governmentality allows us to monitor how this exercise of establishing temporary stabilisations of normality, necessary for a coherent and effective SGP, is articulated in correspondence to unique national exigencies. Uncertainty aligns itself with, and reinforces, the multifarious representations of normalcy. Singular and unique, uncertainty's performative character creates and legitimises alterity as an organising principle behind the SGP. It constitutes the very realities it seeks to describe. In the same instance, the Pact enables and constricts discretion as "it alluringly suggests an open space of possibilities, a freedom of movement and thought" while simultaneously "it closes down political and social space because it names its own condition and renders alternative interpretations" deficient or redundant. ${ }^{15}$ By conditioning the production of knowledge, it exerts a leverage of control over how EMU subjects come to know themselves and therefore how they behave. Through this process, normality becomes polysemic.

Not being able to deduce interests ahead of time, regulators cannot deliver the proper governmental response in advance to pre-empt uncertain circumstances. How actors respond and the interests they advocate at that particular moment are intimately connected to how they interpret the situation as it occurs. Interests, not to mention identities, are discursively bound and continuously renegotiated and rearticulated. ${ }^{16}$ Consequently, acknowledging that normalcy is a politicised social invention, its construction becomes

\footnotetext{
${ }^{14}$ Douglas R. Holmes and George E. Marcus, "Cultures of Expertise and the Management of Globalization," in Global Assemblages: Technology, Politics, and Ethics as Anthropological Problems, ed. Aihwa Ong and Stephen J. Collier (Malden, MA: Blackwell Publishing, 2005), 237.

${ }^{15}$ Louise Amoore, "Risk, Reward and Discipline at Work," Economy and Society 33, no. 2 (2004): 176.

${ }^{16}$ Michel Callon, The Laws of Markets, ed. Michel Callon (Oxford: Blackwell Publishing, 1998).
} 
susceptible to a Lisbonisation of its own. Aggregating and quantifying methods, purporting to uncover the true/objective state of affairs, diminish in utility as normative claims increasingly parallel the broader goals identified in the Lisbon agenda. Subjectification is this sort implicates the subject in particular power relations, which constitute EMU subjectivities as an object of various, prevailing governmental discourses, including good times.

There are two facets to this approach. First, Member States, including all their constitutive units, are objects of government and targets of a regulatory regime that seeks to curtail their propensity towards budgetary excess. Simultaneously, they are subjects of government and involved in designing the very governmental architecture to which they must subsequently adhere to; possibly leading to the imposition of restrictions on their budgetary freedom. Conceptually awkward, whether this relationship between expertise and politics can modulate EMU subjects into self-regulating entities and foster compliance as well as convergence is difficult to predict. Fiscal sovereignty remains a potent force. But if the EU Commission and ECB can exert sufficient leverage on Member States, then clusters, espousing similar notions of normalcy, can develop across Europe's vast fiscal and political landscape. Performativity disputes the facticity of the object/subject dichotomy. Eventually these conventions may coalesce to generate closer affinities between Member States.

Control is notably visible in these matrices of government. It functions across the spatial-temporal terrain of EMU to optimise those tendencies that foster compliance with the SGP statutes and minimises those impulses that could jeopardise this renewed political protocol. The plethora of "exceptional and temporary" variables designed into the 
revamped EDP, which legally exempt Member States from their budgetary obligations, is indicative of this diversity. Similar to the MTRB - functioning at a distance - these forms of control do not transgress against fiscal sovereignty. They are designed to accommodate national expressions of normalcy while curbing the undesirable qualities attributed with the exercise of sovereignty. As the technologies of uncertainty become more prominent in the SGP, their performative character transforms how normalcy is imagined under uncertainty. Expertise then adapts to mobilise these reframed perceptions of normalcy - as a derivative of the representations of contingency - to assign responsibility in the attempt to control the conduct of individual Member States.

Of course, fiscal sovereignty, and all the heterogeneity that it encompasses, must be respected. Both the preventative and corrective mechanisms embody this fundamental principle of the Pact. Budgetary discretion is an artefact of government which permits subjects greater room to navigate a course between their Lisbon ambitions and their commitments under the SGP. Balancing these often conflicting goals of European integration entails that Member States exercise a certain degree of creative entrepreneurialism. That is why the discourse of good times/national fiscal ownership is actively promoted and has penetrated European practice and institutions. It encapsulates ideals of public value creation linked to the Lisbon agenda and the objectives of fiscal austerity necessary for the survival of the Pact. A closer affinity to the common rules may entice governments to pursue more prudent policies during cyclical upswings. What kind of relationship will develop between control and sovereign forms of power remains to be seen. Antagonisms will surely surface but that is to be expected. As it currently stands, 
however, the reforms engendered by the crisis appear to yield to the interests and authority of states.

Sovereignty, assigned a "peripheral role as an outmoded or largely displaced form of power" in this era of accelerating "globalisation," is being rethought since the strategies of government that precipitated the demise of the original Pact helped set the very stage that gave them expression. ${ }^{17}$ My intention is not to explicate the entire "sovereignty problematic" nor discuss it as an abstraction which encapsulates a single notion of the political. ${ }^{18}$ To deny its centrality as a matrix of government is to neglect its constitutive power. As a spatial-temporal order, EMU is conditioned by an assemblage of discursive practices whose authority is very much derived from sovereign power.

How the exercise of this power transforms the politics underpinning fiscal relations through its appropriation of uncertainty, as a mode of governance, is inexorably related to the construction of normalcy. Thus, what is crucial to grasp is the effect that the expanded role of discretionary foresight has on the sovereign dimension of budgetary surveillance. As the demarcation of authority acquiesces to multifarious notions of normalcy, potential hostilities may be minimised. Or they may explode if the ruptures grow and prove irreconcilable. In other words, an analytics of government reveals how various power systems materialise throughout this fragile fiscal framework. Power is reconceptualised within these new preventative and corrective discursive practices. This is the strategic (re)codification of power relations in EMU.

\footnotetext{
${ }^{17}$ Mitchell Dean, Governing Societies: Political Perspectives on Domestic and International Rule (New York: Open University Press, 2007), 15.

${ }^{18}$ For a more comprehensive analysis see R.B.J Walker, Inside/Outside: International Relations as Political Theory (New York: Cambridge University Press, 1993).
} 


\subsection{Global Resonance}

Although many of these concepts where developed in domains distinct from the fiscal or monetary spheres - crime, security, insurance - they share many governmental characteristics and approaches to regulating future liabilities. Today, the deconstructive/reconstructive ethic, popularised by Foucault, has produced legions of scholarly enthusiasts who have applied the genealogical critique in an assortment of forms to numerous areas, ranging from finance ${ }^{1}$ to immigration and asylums ${ }^{2}$ to psychiatry, ${ }^{3}$ just to name but a few. In the study of state monitoring and collective forms of surveillance, there is an interest in how state effects are generated performatively by these technologies of government. A politics of normalisation become discernable which points to the global resonance of neoliberalism.

Subscribing to particular normative positions, complementary to the neoliberal mentality, intergovernmental (IGO) and non-governmental (NGO) organisations are rearranging the political economy of multilateral surveillance. By exposing both state and civil society to the disciplinary forces of the market and commercial law, they are redefining how political power is exercised in the normalisation of governments into compliance. Less intrusive and more indirect, their tactics are often designed to promote an agenda privileging the interests of private capitalism and transnational firms. Whether is it facilitating financial flows or opening access to foreign investment, International Financial Institutions (IFI), such as the IMF or World Bank, are notorious for imposing neoliberal

\footnotetext{
${ }^{1}$ Marieke de Goede, Virtue, Fortune, and Faith: A Genealogy of Finance (Minneapolis: University of Minnesota Press, 2005).

${ }^{2}$ William Walters, "Mapping Schengenland: Denaturalizing the Border," Environment \& Planning D: Society \& Space 20, no. 5 (2002): 561-80.

${ }^{3}$ Peter Miller and Nikolas Rose, ed. The Power of Psychiatry (Cambridge: Polity Press, 1986).
} 
programmes on countries; thereby helping embed the "economy" as "a singular and selfevident totality."4

Advocates of neoliberalism contend that the free play of market forces is essential to maximising individual freedom and quality of life. In direct contrast to, and as a backlash against, "social liberalism" - where the maintenance of societal welfare is the priority of the state - the neoliberal shared mentality rejects the notion of society as a unified entity with discernable needs that must be satisfied through a central apparatus. ${ }^{5} \mathrm{~A}$ preferred conceptualisation envisions the community as a collection of autonomous agents whose quest for happiness is only stifled by excessive governmental interference. Left to their own devises in the marketplace, these innately "free" subjects would rely on their discretionary judgement, in accordance with the natural laws of supply and demand, to guide them in the pursuit of their own visions of happiness. Thus, better governance entails minimal intervention since governments are entrusted with helping facilitate the expression of what are considered natural propensities. In other words, "political imperatives only compromise economic fundamentals, impeding the efficient operation of the market mechanism," which represents the culmination of free decisions. ${ }^{6}$ Here self-sufficiency is intricately interrelated with an entrepreneurialism that rewards calculated risk-taking. Mitigating uncertainty becomes a responsibility shouldered by the individual.

Obviously, accounts such as this are not new to IR. The globalisation of capital is a theme well documented by the likes of Stephen Gill or Bastiaan van Apeldoorn. ${ }^{7}$ Although,

\footnotetext{
${ }^{4}$ J.K. Gibson-Graham, A Postcapitalist Politics (Minneapolis University of Minnesota Press, 2006), 53-56.

${ }^{5}$ Pat O'Malley, Risk, Uncertainty and Government,75.

${ }^{6}$ Colin Hay, "Genealogy of Neoliberalism," in Neoliberalism: National and Regional Experiments with Global Ideas, ed. Ravi K. Roy, Arthur T. Denzau and Thomas D. Willet (New York: Routledge, 2007), 56.

${ }^{7}$ Stephen Gill, "European Governance and New Constitutionalism: Economic and Monetary Union and Alternatives to Disciplinary Neo-liberalism in Europe," New Political Economy 3, no. 1 (1998); Bastiaan van
} 
as I have argued above, Gill's capitalocentricsm falls prey to assigning excessive explanatory value to the structural hegemony of capital, his analysis of how the World Bank actively promotes "a world-wide revolution that creates new obligations for the state" is somewhat insightful. ${ }^{8}$ Amongst the reforms advocated by the World Bank is the prevention of corruption through proper techniques of state building and good governance. Pervasive public sector corruption is perceived as posing a grave danger to the smooth functioning of free markets. Published in numerous reports and papers, such as the "Governance and Anti-Corruption (GAC): Implementation in MNA" brief, are "essential" neoliberal proposals that each country should adopt. ${ }^{9}$ Here good governance is defined as institutionalising market forces through the deregulation of what are considered wasteful layers of bureaucracy.

In its strategic paper, entitled "Strengthening Bank Group Engagement in Governance and Anticorruption," the World Bank reaffirmed its position that governance monitoring should be linked to governance reform. ${ }^{10}$ Passed unanimously, one of the seven core principles stipulated in the GAC implementation plan is the promotion of national fiscal ownership. According to the World Bank, "the country has primary responsibility for improving governance—country ownership and leadership are key to successful implementation."11 Thus, self-regulating tendencies are encouraged which see individual states policing their own conduct. How effective such measures are depends not only on the

Apeldoorn, "Theorizing the Transnational: A Historical Materialist Approach," Journal of International Relations and Development 7, no. 2 (2004): 142-76.

${ }^{8}$ Stephen Gill, "European Governance and New Constitutionalism: Economic and Monetary Union and Alternatives to Disciplinary Neo-liberalism in Europe," 10.

${ }^{9}$ World Bank, Governance and Anti-Corruption (GAC): Implementation in MNA, 22 March, 2009 (Fast Brief 22).

${ }^{10}$ World Bank, Strengthening Bank Group Engagement in Governance and Anticorruption, 17 August 2007(Strategic Paper).

${ }^{11}$ World Bank, "Guiding Principles for Strengthening World Bank Group Engagement on Governance and Anticorruption," available from : http://web.worldbank.org/WBSITE/EXTERNAL/TOPICS.htm. 
supervisory capacity of each jurisdiction but also on active third-party monitoring. Included in this group are auditing agencies, IFIs, and rating agencies, such as Moody's or Standard and Poor's. These can help correct malign impulses as they surface.

A similar discourse is propagated by Transparency International. The Berlin based NGO, has devoted itself to combating corruption around the globe "by raising awareness about its devastating effects, advocating policy reform and the implementation of multilateral conventions, and monitoring compliance by governments, corporations and banks." 12 Barry Hindess examines their "Source Book" to reveal how these practices contribute to advancing a neoliberal programme. While the building of coalitions between NGOs, governmental agencies and the private sector may at first appear like a harmless strategy, Hindess contends that it actually "represents a project of large-scale social engineering" designed to legitimate capital-friendly market conditions. ${ }^{13}$ Important to note is how this discourse is intimately intertwined with the meaning of what constitutes good governance and an managerial approach that tackles the problem through indirect means. As such, this neoliberal programme transfers the responsibility of reform onto the state while IFIs and other organisations adopt a "tutelary" posture.

In many ways, such campaigns parallel what we find in EMU. National fiscal ownership is promoted as a discourse that aligns Member State behaviour with a monetarist construction of normalcy. Rather than interfering directing in the political economy of individual states, the Commission and ECB attempt to activate their endogenous, but latent, responsibility to manage uncertainty in an enterprising fashion. Leverage is exerted through this attempt to steer state conduct without infringing on their fiscal sovereignty. Through a

\footnotetext{
${ }^{12}$ Barry Hindess, "Investigating International Anti-corruption," Third World Quarterly 26, no. 8 (2005): 1389.

${ }^{13}$ Ibid, 1392.
} 
variety of significations, a meaning of what constitutes as "good/normal governance" is inscribed into the fiscal-monetary landscape, progressively eliminating the alterity that exists between Member States. Of course, by no means is this movement a fait accompli. It does demonstrate, however, a new approach to fiscal management as it "disturbs what was previously considered immobile; it fragments what was thought unified" and therefore "shows the heterogeneity of what was imagined consistent with itself." ${ }^{14}$ No longer is the economy a monolithic entity but the contested and temporary fixings of meaning denoting normal fiscal relations.

Modulation of this sort is located in a variety of comparable global assemblages. Through an analytics of government we are better positioned to recover their corresponding significations. As we do so, the trajectory of surveillance can be imagined within these broader fields of control. The purpose is to exploit an indeterminate future though an entrepreneurial spirit in the name of normalcy. But with discretion there is uncertainty. Tensions surface between the programmatic (expertise) and operational (politics) dimensions of organisational life which need to be addressed. As a mode of governance, uncertainty mediates the politics of representation in the effort to reconcile these antagonistic elements. It enables subjects by targeting their individual capacities as calculating entities that must exercise their critical judgement, and therefore regulate themselves, in ways different from risk. This performative element generates specific effects that instill confidence in the restitution of this regulatory space by accelerating particular disjunctions in its political economy. Whether this will stand the test of time is very much in doubt. But for the moment, it is the most agreeable approach available.

\footnotetext{
${ }^{14}$ Stephen J. Rosow, "Echoes of Commercial Society: Liberal Political Theory in Mainstream IPE," in Constituting International Political Economy: International Political Economy Yearbook, Vol. 10, ed. Kurt Burch and Robert A. Denemark (Boulder CO: Lynne Rienner, 1997), 44.
} 


\section{Chapter 6 Into the Great Wide Open}

The above preventative and corrective measures of the Stability and Growth Pact are all calculable practices that have a programmatic ambition. Even uncertainty-centred techniques, which are not uniform and statistically probabilistic, are ways of calculating the future in a manner amenable to management. They are devices that act upon Member States in the attempt to constitute them as economic objects of government susceptible to the programmatic goals embodied in the SGP. To accomplish this effectively requires taking advantage of the fact that "states have an irreducible measure of cultural particularity" through which they may be controlled. ${ }^{1}$ As such, this is a discussion about challenging boundaries and the politics of limits. How knowledge is produced and legitimated is at the heart of this dissertation. Through the diagnostic analytic of governmentality, I have problematised two of the most dominant conceptual and governmental categories which help orient fiscal relations in EMU. All too frequently in IR/IPE, uncertainty - and to a large extent risk - is appropriated in the service of various interests and in multiple ways without any real sense of how it is imagined, articulated or endowed with a performative capacity to render real that which it seeks to describe.

This dissertation proposes an approach to remedying these sins of omission and commission. By problematising this emerging fiscal-monetary space through an analytics of government, we gain an appreciation of the necessary preconditions for its actualisation. I dispute the assertion that EMU objects of government could be constructed "outside of any discursive condition of emergence. ${ }^{2}$ Power and discourse are mutually constitutive.

\footnotetext{
${ }^{1}$ Barry Hindess, "Investigating International Anti-corruption," Third World Quarterly 26, no. 8 (2005): 1396.

${ }^{2}$ Ernesto Laclau and Chantal Mouffe, Hegemony and Socialist Strategy: Towards a Radical Democratic Politics (London: Verso, 1985), 107-08.
} 
Unlike Laclau and Mouffe, however, I proceed to anchor these narratives in the actual regulatory apparatus that endows them with materiality and longevity. Control as calculation is revealed and institutionalised through these discursive practices of identification and prioritisation that are implicit in the Pact. These routine micro-processes monitor a vast array of components contributing to the national fiscal position in the effort to determine and control budgetary liability. Power is exercised through constant surveillance in the struggle for representation. This development is politically charged, pitting various national, subnational, and regional forces against each other as they vie for power in the production of truth and the restitution of the SGP. ${ }^{3}$

With this in mind, my concluding remarks are structured as follows. First, I revisit the SGP problematic and the principal arguments of this dissertation in order to understand the rich new ways governmentality offers to rethinking the politics of fiscal relations in Europe. Conceptualised as a dialectic between expertise and politics, there is a reconfiguration happening that is leading to the Lisbonisation of budgetary governance in EMU. Second, a reflective engagement with the governmentality approach offers two future oriented comments. A theoretical section deliberates some of the tensions that need to be addressed when subscribing to such an interpretative analytic. Governmentality is not without its blemishes. What are the implications of these and do they detract from its explanatory capacity and value-added? Next, an empirical appraisal considers the utility of deploying these analytical tools to the study of the current, global economic landscape.

How does this affect the impending, though ever vulnerable, accession of the new Member States from Central and Eastern Europe into the euro area? These issues are deliberated before I conclude with some final thoughts.

\footnotetext{
${ }^{3}$ All these relationships are also implicated in broader global configurations of power.
} 


\subsection{Rethinking Fiscal Governance}

A principal dimension of fiscal governance is eliminating the deficit bias, which has produced an antagonistic relationship over how normal budgetary relations are imagined by EU experts and how they are practiced by nations. Fiscal profligacy may permit national leaders to meet the challenges facing their countries and satisfy their electorates but it is ultimately unsustainable and incompatible with a common monetary union. Excessive deficits threaten the credibility of the ECB's monetary policy. Nevertheless, fiscal sovereignty is the "sacred cow" of the state and a power which individual governments are not inclined to relinquish any time soon. These political dynamics underlying fiscal governance have been amplified by the conceptual, ideological, and institutional inconsistencies implicit in the original framework, culminating in the SGP crisis. A gruelling process of reform followed, which produced a new Pact in March 2005. It accommodates the heterogeneity of fiscal relations and signals the transition to new uncertainty modes of governance.

Public value creation is trumpeted as a driving catalyst for this (re)politicisation of the European fiscal plane. New regulatory spaces are opening up as the problem of budgetary management is reframed along vectors of uncertainty associated with this movement. Uncertainty, as a construct, involves the mobilisation of the perception of contingency implicit in fiscal relations. As an invention of government, it is helping engineer a novel leverage to control the budgetary conduct of Member States. The hope is to induce the internalisation of self-regulation. Orchestrated through the deployment of a new set of discourses and technologies of uncertainty, it is codified in the 2005 SGP reforms. 
Governing the present through uncertainty is the attempt to reorder the regulatory capacity of EMU to anticipate and respond to fiscal profligacy. Country-specific MTOs in the SCPs and MTBRs exemplify how the "preventative arm" of the Pact reflects a shift to governing singular futures through creative foresight. In conjunction with a more discretionary "corrective arm," uncertainty, as a governmental rationality, informs many of the 2005 reforms. Within these technologies of government are embedded the discourses of good times and national fiscal ownership. They provide the interpretative framework through which EMU subjects come to understand their circumstances and interests under uncertainty. As this configuration of discursive practices disrupts the artificial uniformity of risk management, it grants authority to non-quantitative methods anchored in discretionary human judgement; thereby reconfiguring how expertise functions within EMU. Technical and depoliticised enclosures open up to "test the limitations and the exploration of excluded possibilities." ${ }^{4}$ Highly contestable, this politics of limits is the organisation and production of interests and subjectivities. Its normative prescriptions determine the character of the European political economy.

What is so astonishing is that in the field of IR, and its Political Economy offshoot, risk's, and especially uncertainty's, "utilization, theorization and application...have remained mostly invisible." Dissecting how EMU is influenced by the politics of uncertainty associated with fiscal indiscipline through the governmentality approach allows for a new and more comprehensive understanding of governance that has largely been absent from academic debates. The SGP represents more than just the economic game

\footnotetext{
${ }^{4}$ Richard Ashley and R.B.J. Walker, "Speaking the Language of Exile: Dissident Thought in International Relations," International Studies Quarterly 34, no. 3 (1990): 263.

${ }^{5}$ Darryl S.L. Jarvis and Martin Griffiths, "Risk and International Relations: A New Research Agenda?" Global Society 21, no.1 (2007): 1.
} 
modelling or intergovernmental bargains that many mainstream accounts posit. ${ }^{6}$ These conventional IR theories neglect the discursive shift in the management of fiscal relations. Government through uncertainty "challenges highly rationalistic models of risk analysis which assume away the important psychological and cultural dimensions of risk understanding." ${ }^{7}$ How EMU knowledge is produced and legitimated is central to governance since discourse is a variable in the construction of interests rather than being a derivative of some underlying material reality.

If intergovernmentalist accounts of risk and the SGP crisis are devoid of any serious contestation over meaning then constructivist preoccupations with perception and ideological factors are a stark contrast. ${ }^{8}$ As mentioned, identity is neither fixed nor assigned an ontological priority for these theorists. There is no exogenous reality outside of the ideational constitution of EMU to be measured and quantified. Interests and identities are endogenous as they are manufactured through social practice. Hence, the instrumental rationality and atomistic conceptions of social phenomena, informing state-centric understandings of uncertainty, are visibly absent. That, however, does not preclude constructivism from criticism directed at its analytical postulates.

A main charge levelled at constructivists is that they fail to adequately explain how new knowledge is produced and legitimated through the politics of uncertainty. This ambiguity is most pronounced with reference to the extra-discursive restrictions on the production of meaning. Uncertainty, as a frame for the socialisation process, is susceptible

\footnotetext{
${ }^{6}$ Patrick Leblond, "The Political Stability and Growth Pact is Dead: Long Live the Economic Stability and Growth Pact," Journal of Common Market Studies 44, no. 5 (2006): 969-90.

${ }^{7}$ Michael Power, The Risk Management of Everything (London: Demos, 2004), 16.

${ }^{8}$ Jeffrey Checkel, "The Constructivist Turn in International Relations Theory," World Politics 50, no. 2 (1998); Thomas Risse, "Social Constructivism and European Integration," in European Integration Theory, ed. Antje Wiener and Thomas Diez (New York: Oxford University Press, 2004).
} 
to this logic which is divorced from the site of articulation. Removed from discursive instantiations, this limit on what is permissible hinders social constructivist contributions to EMU since the difference between perception and actualisation is suspended. Subjectivity materialises at these points of social interaction, which are nevertheless subject to an external force.

Whereas historical materialists may welcome such an interpretation, as extrasemiotic mechanisms have the potential to dialectically reinforce the materiality of structures, it is damaging for constructivists intent on explaining the SGP crisis as the management of systems of representation. ${ }^{9}$ The regulation of uncertainty is dependent on how it is framed as an object of governance. A clear analytical framework delineating how uncertainty is transformed into a modality of rule in order to render EMU real is necessary. Lacking one, we are left with deciphering not an autonomous fiscal-monetary space, with its own set of articulations, but one susceptible to an exogenous influence directing its constitution.

Unsatisfied with the conventional IR explications, my dissertation interrogates the heterogeneous governmental responses to the problem of fiscal profligacy in order to reveal the changing mentality behind them and the reconfiguration of the devices in which they are embedded. By diagnosing the alternative assessment and application of the new SGP in relation to the problem of fiscal profligacy, we come to understand the production of truth for the purposes of regulating fiscal conduct under uncertainty. Here I address the first overarching question behind this dissertation; namely how does the differentiated assessment of the SGP problematise EMU management? My contention is that this (re)politicisation of fiscal relations has been reflected in and magnified by the transition

\footnotetext{
${ }^{9}$ Bob Jessop, State Power: A Strategic-Relational Approach (Malden, MA: Polity Press, 2008), 237-40.
} 
from a predominantly risk-centred system of management to government through contingency in EMU. Tracing the shift in how the SGP is imagined as an object of rule, my critical genealogy disturbs the perceived uniformity of risk as a governmental category to reveal the alterity underpinning fiscal relations. Increasingly, uncertainty is a way EMU officials, and national leaders, render reality in order to govern.

Significant to note is that the relationship between risk and uncertainty is not based on mutual exclusion. Neither one is inherently more or less abundant in this post-2005 environment. Although there is the tendency to discuss these matters in zero-sum terms, since the prominence of risk as an aggregating method has been welcomed extensively in our neoliberal societies, it presents an artificial binary opposition where none exists. Rather risk "has become polysemic, a discursive shift that needs to be discussed as a phenomenon rather than eliminated by definitional fiat. ${ }^{10}$ Analysing how EMU is imagined as an object of government, by employing uncertainty as a mentality of rule, accomplishes just this. To differentiate what these governmental categories represent and how they are applied, I diagram the increasing visibility of discourses and technologies predicated on contingent frames. Yet the interesting observation is not that there are more of them. Rather it is how uncertainty mediates the politics of representation associated with the problem of fiscal profligacy, or the production of truth, and how these perceptions are mobilised in the form of a new regulatory apparatus.

Rethinking how processes of signification inscribe particular meanings of what constitutes as normal fiscal conduct demonstrates the temporality underpinning the continuous negotiation of this project. Rooted in the discursive practices of German

\footnotetext{
${ }^{10}$ Lorna Weir, "Recent Developments in the Government of Pregnancy," Economy and Society 25, no. 3 (1996): 383.
} 
politics, with memories of 1920 s hyperinflation and the prominent role of the Bundesbank, risk techniques became more popular with an overreliance on dubious metrics fashionable in the 1990s. The desire for aggregating methodologies, which could account for the transfer of power from the nation-state to the EU level, only fuelled their adoption and dissemination in the context of EMU.

Assigning a probability distribution to an outcome is said to produce the optimal allocation which yields the highest utility. Measuring variance through risk calculations could transform the management of an indeterminate future into a regularly quantifiable exercise. Here the margin of error is purportedly minimised by statistical metrics, dubbed "machineries of knowledge," to such a perceived extent it is considered an objective account of reality. ${ }^{11}$ But "qualculation" seeks to divorce technoscientific epistemology from its socio-political context rather than acknowledge the relational and constitutive power exercised in recoding matrices of government. Risk is backward looking and relies on the past reproducing itself at regular interval. However, persistent variability and unique situations, characteristic of EMU, are better understood and operationalised through the mode of uncertainty.

Social idiosyncrasies and political compulsions do not readily lend themselves to the sequencing of statistical-probabilistic calculations. National agents - not to mention markets - often act on impulse and no risk management framework can entirely, or accurately, capture all possible exigencies in order to deliver an ex ante governmental response. This tackles the second principal question or what is the regulatory capacity through which risk and uncertainty are delivered as modes of governance? Whether they

\footnotetext{
${ }^{11}$ Karin Knorr Cetina, Epistemic Cultures. How the Sciences Make Knowledge (Cambridge: Harvard University Press, 1999), 5.
} 
are amended preventative mechanisms, such as the differentiated MTOs, or part of the dissuasive arm, like the EDP, these revisions exhibit a new understanding of the problem of fiscal relations. Their interrogation allows for an assessment of the SGP's relative merits as a field of intervention. Here uncertainty acts as boundary object in the normalisation of this constructed space of government. It seeks to unite dispersed sites across Europe's fiscal terrain, at yet undetermined future points in time, to mitigate potentially undesirable propensities towards profligacy. Together with risk, they animate the economy of power in which EMU is implicated, thereby endowing it with a density and a history.

Modifications of the Pact have broadened the discretionary purview of Ecofin in enforcing the statutes. Ostensibly, the relative authority of the Commission has diminished. This is indicative of a shift in the prioritisation of particular discourses over others. Whereas the programmatic dimension complements the logic of stability embedded within risk, uncertainty is perceived a source of creative enterprise. Contingency allows for the exploitation of unexpected market opportunities to enhance wealth production. Member States are envisioned as entrepreneurs seeking to maximise their utility in the actualisation of their Lisbon objectives. At once, an appetite for macroeconomic stabilisation is pitted against one for debt sustainability and the promise of public value creation. A tension ensues between the two competing logics of legitimacy and enterprise, which is conceptualised as a dialectic between expertise and politics. Each privileging a distinct priority of EMU, the task of locating a mutually corresponding, and enforceable, understanding of what constitutes normal fiscal behaviour - including how to regulate deviance across Europe - appears dim. Irreconcilable differences have made devising a single normative standard for maintaining fiscal discipline unattainable for the moment. 
But this should not be surprising given the heterogeneous composition of European political economies. In order to preserve a semblance of control, which can foster enhanced compliance, as a precursor for convergence, variegated notions of normalcy are being validated that reflect this variability and diversity implicit in economic affairs. Again, the struggle for representation is proving too heated and diffuse to be accommodated in one norm. A genealogical excavation of this fiscal terrain reveals how competing interpretations of normalcy play out to supply the necessary normative anchor for these revised programmes and technologies of government. Doing so, I ascertain how this assemblage obtains the power to define the parameters and subjects of EMU in the restitution of the Pact.

As mentioned, fiscal sovereignty must be respected. But to compel Member States to coalesce around shared conventions, that can minimise the frictions stemming from alterity, forms of control are more visible with this managerial shift towards uncertainty. After the institutional paralysis experienced in 2003, EU officials recognised the need to strike a balance between granting Member States sufficient room to manoeuvre, in the pursuit of their Lisbon ambitions, and enforcing the statutes. Self-regulating tendencies which promote compliance are optimised and malignant dispositions are minimised through "forms of ceaseless control in open sites." ${ }^{12}$ Such modulation of fiscal conduct is intended to induce the internalisation of self-regulation since members are envisioned as enterprising subjects entrusted with the responsibility of prudently managing their fiscal books. It comprises a novel leverage that is exerted by the organisational apparatus to normalise EMU subjects into compliance. The new Pact contributes to constructing this

\footnotetext{
${ }^{12}$ Gilles Deleuze, "Control and Becoming," in Negotiations, ed., trans. by Martin Joughin (New York: Columbia University Press, 1995), 175.
} 
emerging spatial-temporal order as a constrained field of regulated discretion where subjects are at once susceptible to processes of subjectification and drivers of it.

\subsection{Theoretical and Empirical Resonance}

In the introductory chapters of his investigation into alternative approaches to contemplating contemporary regimes of government, Nikolas Rose distinguishes the merits of an analytics of government from that of the arguably banal concept of "governance." The latter he denotes as a "kind of catch-all to refer to any strategy, tactic, process, procedure or programme for controlling, regulating, shaping, mastering or exercising authority over others in a nation, organization or locality." ${ }^{, 13}$ Rose, echoing Foucault, rejects this realist conception of governance for both its normative as well as descriptive elements. Juxtaposed against sociologies of governance, which espouse a normative judgement about the outcome of predetermined systems of rule, governmentality studies diagnose the "conditions of possibility and intelligibility for certain ways of seeking to act upon the conduct of others, or oneself, to achieve certain ends." ${ }^{\text {"14 }}$ Their salience derives not from some inescapable logic but from their exposition of the intellectual apparatus deployed to render reality thinkable in terms of its susceptibility to governmental intervention.

Despite the rigour with which Rose and company formulate their analytics and conduct their research, an outstanding unease nevertheless remains. Though the preoccupation of governmentality studies may not be with the substantive content of political economy, many are prone to both the charge of description and normativity. Arguably, they are descriptive in the sense that the interpretative analytic canvasses how we come to problematise thinking about and acting on the capacities of government. Such a

\footnotetext{
${ }_{13}^{13}$ Nikolas Rose, Powers of Freedom (New York: Cambridge University Press, 1999), 15.

${ }^{14}$ Ibid, 19.
} 
genealogical analysis actually entails a certain degree of static observation as one attempts to capture and diagram a history and latency in order to diagnose and critique it according to its vectors of thought. Implicit in these "how" questions is an "anamnestic" tendency to commence with a material examination of what already exists. Any "interrogation of the epistemological status" of the "economy" proceeds with a thorough documentation of how it is "territorialised" through multiple discursive practices, which render it amenable to calculative programmes of government. ${ }^{15}$ Given its opposition to explaining the development of government in terms of a teleological trajectory, a history of the present "will cultivate the details and accidents that accompany every beginning; it will be scrupulously attentive to their petty malice."16 Such meticulousness often endows governmentality with a descriptive character.

"Political prosaics" may offer substantial insight into matters that which hitherto been either neglected or taken for granted. ${ }^{17}$ They disturb the monopoly of sovereignty as the chief organising principle in IR or the hegemony of class consciousness. Time and space are afforded a serious audience. But interrogations can stray into the realm of the pedantic when their fascination with the micro-world comes at the expense of broader macro issues of material inequality or international foreign relations. By being overly descriptive, in terms of the minutia of its study, an analytics of government can privilege a static portrayal of its subject matter while eschewing more dynamic and overarching developments. These do not necessarily have to be structural properties; although often they are.

\footnotetext{
${ }^{15}$ William Walters, “Decentring the Economy," Economy and Society 28, no. 2 (1999): 314.

${ }^{16}$ Michel Foucault, "Nietzsche, Genealogy, History," in The Foucault Reader, ed. Paul Rainbow (New York: Pantheon, 1984), 80.

${ }^{17}$ David Campbell, "Political Prosaics, Transversal Politics," in Challenging Boundaries, ed. Michael J. Shapiro and Hayward R. Alker ((Minneapolis: University of Minnesota Press, 1996).
} 
Rather the static optics are reinforced by a nuanced relativism, which is derived from a plethora of interpretative analytics - each accentuating the significance of its own microcosm - but without any real sense of a hierarchy that orders them either analytically or in the material world. Because everything is so diluted, everything may be equally important. Of course, we are cognisant of the fact that hierarchies, reflecting broader agendas, do in fact exist in society. Borders may indeed constitute the centre of European political activity rather than demarcating its margins, as Balibar contends. ${ }^{18}$ But what precludes an infinite regression from occurring which, at some point, becomes redundant to anybody but the researcher and a handful of colleagues? Limits need to be recognised that parallel real world valuations. Otherwise, the project is consigned to the "ivory towers."

Not to discount the rich contributions that these studies have made to our understanding of social phenomena, there is also a certain tension that surfaces whenever a genealogical mode of interpretation is employed, which should be noted when discussing normalcy. To apply the method of deconstruction in an effort to reveal the contestable constitution of subjectivity within a domain of discourse, known as the process of "subjectification," and thus deprive it of its false universality and inevitability, as it "dispels the chimeras of the origin," is itself a normative position. ${ }^{19}$ Mitchell Dean acknowledges that while:

an analytical framework seeks to describe second-order statements about governing which comprise 'rationalities of government' and the techniques and technologies to which they are linked. It also enjoins us in a normative sense to problematize or call into question and to make strange the rationalities by which we make these first-order statements. ${ }^{20}$

\footnotetext{
${ }^{18}$ Etienne Balibar, Politics and the Other Scene (London: Verso, 2002).

${ }^{19}$ Michel Foucault, "Nietzsche, Genealogy, History," in The Foucault Reader, ed. Colin Gordon (New York: Pantheon, 1984), 80.

${ }^{20}$ Mitchell Dean, Governing Societies: Political Perspectives on Domestic and International Rule (New York: Open University Press, 2007), 50.
} 
To lambast conventional ways of thinking for their inability to adequately comprehend the exercise of power by contending that, in two centuries since the deposition and execution of absolutist monarchs, the "field of political thought had not yet cut off the king's head" could be interpreted as a provocation. ${ }^{21}$ Not surprisingly, a normative challenge may be extracted from such statements designed to antagonise in efforts to produce a dialogue.

After all, they imply that a better alternative to misguided mainstream accounts does in fact exist.

Whether or not this disposition actually detracts from the value-added of governmentality studies is probably superfluous. Questions such as this yield little because governmentality does not purport to be a "grand theory" espousing a unified position in the explanation of causal relationships. In part, this is why I refrained from labelling this research as "poststructuralist political economy." Nevertheless, those operating within this “ethos" must be cognisant of what doing so actually entails; including its normative prescriptions. That is why my research tackles the problem of underlying the construction of normalcy. We need to come to terms with how it is appropriated in the context of, what appear as, ever widening rifts in the field of fiscal relations. Moreover, what are the lineages that connect it with broader discursive fields to generate specific state effects? That being said, the reconstructive analytic is itself a normative stance which can yield a specific interpretation of what constitutes normality in EU. Awareness of this can preclude the imposition of our own cognitive frames onto the EU.

One further word is appropriate when discussing the articulation of first-order statements and modes of subject formation. Quite often, governmentality studies are

${ }^{21}$ Nikolas Rose and Peter Miller, "Political Power Beyond the State," British Journal of Sociology 43, no. 2 (1992): 174. 
accused of neglecting any serious discussion of the constitution and nature of agency in favour of micro-analyses detailing technologies of power and the relationships they engender. ${ }^{22}$ Unless there is some semblance of rejuvenated agency amidst this enterprise committed to the "death of the subject" then the study of governmentality is susceptible to being "captured by its own privileged object, the governmental discourse." 23 Jessop and Sum advance a similar line of argumentation. They contend that by assigning theoretical priority to the mechanics of systems of power, at the expense of agency, Foucauldian approaches appear blind to the structural production and reproduction of macrohegemony witnessed through the "coconstitution and coevolution of the material and the discursive."24 In order to account for the actual performative power of discourse in the provision of the macrosocial order:

specific economic and political imaginaries and their associated discursive practices must have some significant, albeit necessarily partial, correspondence to real material interdependencies in the actually existing economic and political fields and their articulation in the wider ensemble of social relations. ${ }^{25}$

Heavily indebted to Poulantzas, Jessop's ambition to develop a strategic-relational "cultural political economy" in fact represents a punctilious synthesisation of Foucault through a neo-Gramscian approach. Far removed from the reductionist determinism of vulgar Marxist theory, and refined over time, Jessop ultimately grounds this mediation in what he considers "real" material forces. Within this tradition, coconstitution does not suggest the calibrated equivalence of the discursive and the material. Their relationship is one of

\footnotetext{
${ }^{22}$ Alexander Wendt, Social Theory of International Politics (New York: Cambridge University Press, 1999); John G. Ruggie, "Territoriality and Beyond: Problematizing Modernity in International Relations," International Organization 47 (1993): 139-74; Bob Jessop, The Future of the Capitalist State (Cambridge: Polity, 2002).

${ }^{23}$ Mitchell Dean, Governing Societies: Political Perspectives on Domestic and International Rule, 51.

${ }^{24}$ Bob Jessop and Ngai-Ling Sum, "Towards a Cultural International Political Economy: Poststructuralism and the Italian School" in International Political Economy and Poststructural Politics, ed. Marieke de Goede (New York: Palgrave Macmillan, 2006), 157.

${ }^{25}$ Ibid, 160.
} 
asymmetry. Thus, as noted above, a certain residual economism persists, detracting from its explanatory value. That being said, EU studies must, nevertheless, avoid a "structureless agency" where technologies and discourses are increasingly divorced from the actors that devise and disseminate them. After all, imaginary begins with the individual.

These theoretical considerations need to be contextualised in terms of particular empirical questions animating European political economy today. Recent recessionary pressures, spurred by the global credit crisis, only amplify the resonance of the government through uncertainty. ${ }^{26}$ Greater room to manoeuvre in deciding what constitutes as normal fiscal conduct has proven indispensible in keeping EMU intact and avoiding the kind crippling episode witnessed in 2003. By defining "exceptional" circumstances as being normal within the context of particular states, while engaging in prudent reviews, the EU has been able mitigate the uncertainty associated with appropriate exit strategies by remedying the "discrepancy between cognitive capacities and situational complexity."27 Enhancing how and when information is processed can determine the course of action pursued. It can modify how the fiscal experience is temporally framed and influence the pace of adjustment as stimulus is removed.

Substantial political capital needs to be invested by the large players (i.e. Germany) at this time to endow the revised Pact with the necessary credibility to meet the challenges of recovery. If the proper tone can be set in these unprecedented circumstances, then the task of managing procyclicality in good times may prove less taxing. But an enhanced sense of legitimacy is also vital in light of the looming membership of the remaining Central and Eastern bloc states. With a severe currency and debt crisis in Latvia - part of

\footnotetext{
${ }^{26}$ In fact, dubious risk metrics are said to have contributed to this entire mess.

${ }^{27}$ Jens Beckert, Beyond the Market: The Social Foundations of Economic Efficiency, 40.
} 
ERM II - compounded by an extremely fragile situation in Hungary, how does the imminent membership of the remaining former Soviet Bloc states problematise European economic and monetary integration? Furthermore, what does the euro area enlargement to the East mean for European political economy?

Once again, risk and uncertainty are helping frame the accession debate. When and how these new countries will adopt the euro, and the potential consequences of this transition, are only complicated by the effects of the recent credit crisis. Current members may be crawling out of recession, but there is no voracious appetite to expand the eurozone on the part of either France or Germany any time soon. Dates are being revised and pushed back across most of Central and Eastern Europe. Welcoming developing economies at a time when any economic recovery remains fragile is not preferred; especially when they are experiencing difficulty in meeting, or maintaining, the convergence criteria. Another crisis, triggered by premature accessions, would be disastrous. Thus, with the expansion of the euro area, the spatialisation of governance presents novel challenges in the attempt to reconcile diverse political and economic cultures, cycles and structures.

But this is not simply an East versus West issue. Alarms are also being raised about the potential for debt default across the eurozone. The Depository Trust and Clearing Corporation, which processes the clearance and settlement of derivative trades, has witnessed a spike in the amount of Credit-Default Swaps (CDSS), a form of insurance, taken out against government bonds. Investors, fearing that Italy is the most susceptible to default risk, have purchased $\$ 23.7$ billion of these products, limiting the liability of their exposure to the country's growing debt. ${ }^{28}$ What is more distressing is that the top nine

28 "Biggest Sovereign CDS Positions," The Economist, December, 2009, 110. 
economies ranked by the firm are members of the euro area. Fitch has recently downgraded Greece's credit rating from A- to BBB+.

Figures of this sort only raise more questions about the Pact's functionality in this volatile climate. Without being seriously tested, the new Pact's real credibility remains very much in doubt. Its newfound institutional integrity must be not impede any recovery. Whether it can weather these storms requires a clear understanding of the particular challenges facing each Member State. Policy prescriptions will vary to suit the context. As modes of governance, risk and uncertainty can help formulate the appropriate regulatory response.

In light of the persistent stream of failures and challenges facing the architects of the SGP, and criticisms of its anti-growth bias and pro-cyclical nature, alternative modes of governance are also being entertained. One is of particular interest. Restoring confidence and stability by assigning actors to risk pools, which recast them as calculative and prudent liberal subjects capable of controlling their susceptibility to failure, including to fiscal profligacy, may prove increasingly attractive. If so, would a different model of fiscal coordination as a form of collective insurance be more effective in achieving legitimate stabilisation with "actuarial" power as its most prominent articulation? Rather than continuing with the "disciplinarian device" rationality or that of control societies visible with the current SGP, a "stabilisation as insurance" approach to fiscal policy coordination pools the uncertainty of national economies experiencing asynchronous business cycles at a higher level of aggregation. ${ }^{29}$ Compensation as opposed to punishment would be favoured in the event of a negative shock. However,

\footnotetext{
${ }^{29}$ Waltraud Schelkle, "The Political Economy of Fiscal Policy Co-ordination in EMU: From Disciplinarian Device to Insurance Arrangement," Journal of Common Market Studies 43, no. 2 (2005): 378.
} 
this should not be construed as a perfect solution because certain inadequacies surface that detract from its value; its tolerance for variation being one. Nevertheless, it does direct attention to what is understood as legitimate practice and the political rationalities that underpin it.

My genealogy highlights the development and regulation of this emerging fiscalmonetary space, known as EMU, by focusing our attention on the discursive shift in its political economy of surveillance. Through a deconstructive/reconstructive analytic, the sedimentation of uncertainty, as a mode of governance, in the institutional infrastructure of the SGP becomes apparent. This reveals how the revamped Pact signals an alternative approach to framing the problem of regulating budgetary relations by targeting the endogenous responsibility of Member States to manage their own uncertainty. It reconnects the technoscientific epistemology with its socio-political context rather than keeping it divorced from its politicised relationships. Compliance is not guaranteed and convergence even less so. However, this analysis reveals "a compulsory repetition of prior and subjectivating norms, ones that cannot be thrown off at will, but which work, animate, and constrain the...subject." ${ }^{, 30}$ In time, if the EU can exert sufficient leverage on Member States then similar notions of normalcy may develop across Europe's vast fiscal and political landscapes. Perceptions of uncertainty will be minimised and EMU held intact.

\footnotetext{
${ }^{30}$ Frederick Roden, "Becoming Butlerian: On the Discursive Limits (and Potentials) of Gender Trouble at Ten Years of Age," International Journal of Sexuality and Gender Studies 6 (2001): 27.
} 


\section{Bibliography}

Abdelal, Rawi. "Writing the Rule of Global Finance: France, Europe, and Capital Liberalization." Review of International Political Economy 13, no. 1 (2006): 1-27.

Adams, John. Risk. London: UCL Press, 1995.

Althusser, Louis. Politics and History. London: New Left, 1972.

Amoore, Louise. "Risk, Reward and Discipline at Work." Economy and Society 33, no. 2 (2004): 174-96.

Amtenbrink, Fabian and Jakob De Haan. "Economic Governance in the European Union: Fiscal Policy Discipline versus Flexibility." Common Market Law Review 40 (2003): 1075-106.

Annett, Anthony. "Enforcement and the Stability and Growth Pact: How Fiscal Policy Did and Did Not Change under Europe's Fiscal Framework." IMF Working Paper 116 (2006): 1-32.

Arestis, Philip and Malcolm Sawyer. "Macroeconomic Policy and the European Constitution." In Alternative Perspectives on Economic Policies in the European Union, edited by Philip Arestis and Malcolm Sawyer. New York: Palgrave MacMillan, 2006.

Arrow, Kenneth J. and Gerald Debreu. "Existence of an Equilibrium for a Competitive Economy." Econometrica 22, no. 3 (1954): 225-90.

Artis, Michael J. and Bernhard Winkler. "The Stability Pact: Safeguarding the Credibility of the European Central Bank." CEPR Discussion Paper 1688 (1997).

Artis, Michael J. and Luca Onorante. "The Economic Importance of Fiscal Rules." In The Travails of the Eurozone: Economic Policies, Economic Developments, edited by David Cobham. New York: Palgrave Macmillan, 2007.

Ashley, Richard and R.B.J. Walker. "Speaking the Language of Exile: Dissident Thought in International Relations." International Studies Quarterly 34, no. 3 (1990): 25968.

Axford, Barrie and Richard Huggins. "Towards a Post-National Polity: The Emergence of the Network Society in Europe." In Whose Europe? The Turn Towards Democracy, edited by Dennis Smith and Sue Wright, 121-47. Oxford: Blackwell, 1999.

Balibar, Etienne. Politics and the Other Scene. London: Verso, 2002. 
Bank for International Settlements. "Basel II: Revised international capital framework." Available from http://www.bis.org/publ/bcbsca.htm.

Barry, Andrew. "Lines of Communication and Spaces of Rule." In Foucault and Political Reason: Liberalism, Neo-liberalism and Rationalities of Government, edited by Andrew Barry, Thomas Osborne, and Nikolas Rose, 123-141. Chicago: The University of Chicago Press, 1996.

Barry, Andrew. "In the Middle of the Network." In Complexities: Social Studies of Knowledge Practices, edited by John Law and Annemarie Mol, 142-65. Durham: Duke University Press, 2002.

Barry, Andrew and Don Slater. "Introduction." In The Technology Economy, edited by Andrew Barry and Don Slater, 1-27. New York: Routledge, 2005.

Basel Committee on Banking Supervision. "Operation Risk Management." Available from http://www.bis.org/publ/bcbs42.pdf?noframes=1.

Basel Committee on Banking Supervision. "Sound Practices for the Management and Supervision of Operation Risk." Bank of International Settlements (2003).

Available from http://www.bis.org/publ/bcbs96.pdf.

Basel Committee on Banking Supervision. "Basel II: International Convergence of Capital Measurement and Capital Standards: A Revised Framework." Bank of International Settlements (2005). Available from http://www.bis.org/publ/bcbs 118 . pdf?noframes $=1$.

Beck, Ulrich. World Risk Society. London: Polity, 1999.

Beck, Ulrich, Anthony Giddens, and Scott Lash. Reflexive Modernization. Cambridge: Polity Press, 1994.

Beckert, Jens. "What Is Sociological about Economic Sociology? Uncertainty and the Embeddedness of Economic Action." Theory and Society 25, no. 6 (1996): 803-40.

Beckert, Jens. Beyond the Market: The Social Foundations of Economic Efficiency. Princeton, N.J.: Princeton University Press, 2002.

Begg, Iain and Waltraud Schelkle. "The Pact is Dead: Long Live the Pact." National Economic Institute 189 (2004): 86-98.

Bernstein, Peter. Against the Gods: The Remarkable Story of Risk. New York: Wiley, 1998.

Bieling, Hans-Jurgen. "EMU, Financial Integration and Global Economic Governance." Review of International Political Economy 1, no. 3 (2006): 420-48. 
Blyth, Mark. Great Transformations: Economic Ideas and Institutional Changes in the Twentieth Century. New York: Cambridge University Press, 2002.

Blyth, Mark. "When Liberalisms Change: Comparing the Politics of Deflations and Inflations." In Neoliberalism: National and Regional Experiments with Global Ideas, edited by Ravi K. Roy, Arthur T. Denzau, and Thomas D. Willet, 71-96. New York: Routledge, 2007.

Bongardt, Annett and Francisco Torres. "Is the 'European Model' Viable in a Globalized World?" In Globalization, Development and Integration: A European Perspective, edited by Pompeo Della Posta, Milica Uvalic, and Amy Verdun, 215-231. New York: Palgrave Macmillan, 2009.

Boyer, Robert. "How and Why Capitalisms Differ." Economy and Society 34, no. 4 (2005): 509-557.

Buiter, Willem Hendrik. "How to Reform the Stability and Growth Pact?" Central Banking 13, no. 3 (2003): 49-58.

Buiter, Willem Hendrik. "The 'Sense and Nonsense of Maastricht' Revisited: What Have We Learnt about Stabilization in EMU?" Journal of Common Market Studies 44, no. 4 (2006): 687-710.

Buti, Marco. "Will the New Stability and Growth Pact Succeed? An Economic and Political Perspective," January 2006. Available from http://europa.eu.int/comm/ economfinance/publications/economic_papers/2006/ecp24len.pdf; Internet.

Buti, Marco and Gabriele Giudice. "Maastricht's Fiscal Rules at Ten: An Assessment." Journal of Common Market Studies 40, no. 5 (2002): 823-48.

Buti, Marco and Lucio R. Pench. "Why Do Large Countries Flout the Stability Pact? And What Can Be Done About It?" Journal of Common Market Studies 42, no. 5 (2004): 1025-1032.

Buti, Marco, Sylvester Eijffinger, and Daniele Franco. "Revisiting the Stability and Growth Pact: Grand Design or Internal Adjustment?" CEPR Discussion Papers 3692 (2003).

Butler, Judith. Bodies That Matter: On the Discursive Limits of "Sex." New York: Routledge, 1993.

Cafruny, Alan W. "Europe, the United States, and Neoliberal (Dis)Order." In A Ruined Fortress? Neoliberal Hegemony and Transformation in Europe, edited by Alan W. Cafruny and Magnus Ryner, 285-306. Lanham, Md.: Rowan \& Littlefield, 2003. 
Cafruny, Alan W. and J. Magnus Ryner. "A Coming Crisis of the Euro? The Transatlantic Subordination and Social Contradictions of the EMU." Paper Presented at the Annual Meeting of the International Studies Association, Montreal, Quebec, Canada, 17-20 March 2004.

Cafruny, Alan W. and J. Magnus Ryner. Europe at Bay: In the Shadow of US Hegemony. Boulder: Lynne Rienner, 2007.

Cafruny, Alan W. and J. Magnus Ryner. "Is the SGP Crisis Also the Crisis of the EU? Assessing the EMU from a Structural, Transatlantic Perspective." In Between Growth and Stability: The Demise and Reform of the European Union's Stability and Growth Pact, edited by Lea Simona Talani and Bernard Casey. Edward Elgar: Northampton, MA, 2008.

Calderia, Vitor. "The Coordination of Internal Controls: The Single Audit-Towards a European Union Internal Control Framework." In Public Expenditure Control in Europe, edited by M.G. Crespo, 184-210. Northampton: Edward Elgar, 2005.

Callon, Michel. "An Essay on Framing and Overflowing: Economic Externalities Revisited by Sociology." In The Laws of Markets, edited by Michel Callon, 1-57. Oxford: Blackwell Publishing, 1998).

Callon, Michel. "Introduction: The Embeddedness of Economic Markets in Economics." In The Laws of Markets, edited by Michel Callon, 1-57. Oxford: Blackwell Publishing, 1998).

Callon, Michel. "Performative Economics." In Do Economists Make Markets? On the Performativity of Economics, edited by Donald MacKenzie, Fabian Muniesa, and Lucia Siu, 311-57. Princeton: Princeton University Press, 2007.

Campbell, David. Politics without Principle: Sovereignty, Ethics and the Narratives of the Gulf War. Boulder, CO: Lynne Rienner, 1993.

Campbell, David. "Political Prosaics, Transversal Politics." In Challenging Boundaries, edited by Michael J. Shapiro and Hayward R. Alker, 7-31. Minneapolis: University of Minnesota Press, 1996.

Campbell, David. National Deconstruction: Violence, Identity and Justice in Bosnia. Minneapolis: University of Minnesota Press, 1998.

Cameron, Angus and Ronen Palan. The Imagined Economies of Globalization. Thousand Oaks, CA: Sage, 2004. 
Castel, Robert. "From Dangerousness to Risk." In The Foucault Effect, edited by Graham Burchell, Colin Gordon, and Peter Miller, 281-298. Chicago: Chicago University Press, 1991.

Cetina, Karin Knorr. Epistemic Cultures. How the Sciences Make Knowledge. Cambridge: Harvard University Press, 1999.

Chalmers, Damian and Martin Lodge. "The Open Method of Co-ordination and the European Welfare State," Discussion Paper 11. London: LSE Centre for the Analysis of Risk and Regulation, June 2003.

Chandler, William M. "German Influence in Shaping EMU: Still a Tamed Power?" In The Euro: European Integration Theory and Economic and Monetary Union, edited by Amy Verdun, 201-14. Lanham, Md.: Rowman \& Littlefield Publishers, 2002.

Chang, Michele "Reforming the Stability and Growth Pact: Size and Influence in EMU Policymaking," Journal of European Integration 28, no. 1 (2006): 107-20.

Checkel, Jeffrey. "The Constructivist Turn in International Relations Theory." World Politics 50, no. 2 (1998): 324-48.

Checkel, Jeffrey. "Social Construction and Integration." ARENA Working Papers 14 (1998b): 10. Available at http://www.arena.uio.no/publications/wp98_14.htm.

Chorafas, Dimitris N. Risk Management Technology in Financial Services. New York: Elsevier, 2007.

Christiansen, Thomas, Knud Erik Jorgensen, and Antje Wiener, ed. The Social Construction of Europe. (Thousand Oaks, CA: Sage Publications, 2001).

Coeure, Benoit and Jean Pisani-Ferry. "Fiscal Policy in EMU: Towards a Sustainability and Growth Pact." Oxford Review of Economic Policy 21, no. 4 (2005): 598-617.

Collignon, Stefan. "The Three Sources of Legitimacy for European Fiscal Policy." International Political Science Review 28, no. 2 (2007): 155-84.

Comte, Auguste. Discourse on the Positive Spirit. Paris, 1844.

Connolly, William. "The Irony of Interpretation." In The Politics of Irony: Essays in SelfBetrayal, edited by Daniel W. Conway and John E. Seery, 119-50. New York: St. Martins, 1992.

Council of the EU. Lisbon Spring European Council: Presidency Conclusions, 23 and 24 March 2000, 5256/00, REV 1, CONCL 1. Lisbon, 2000.

Council of the EU. Brussels Spring European Council: Presidency Conclusions, 22 and 23 March 2005, 7619/1/05, REV 1, CONCL 1. Brussels, 2005. 
Council of the EU. Council Regulation (EC) No 1055/2005: Amending Regulation (EC) No 1466/97 on the Strengthening of the Surveillance of Budgetary Positions and the Surveillance and Coordination of Economic Policies, 7 July 2005, EC (2005).

Council of the EU. Council Regulation (EC) No 1056/2005: Amending Regulation (EC) No 1467/97 on Speeding Up and Clarifying the Implementation of the Excessive Deficit Procedure, 7 July 2005, EC (2005).

Council of the EU. Improving the Implementation of the Stability and Growth Pact, Report to the European Council, 7423/05, Brussels, 2005.

Council of the EU. Press Release, 2741 $1^{\text {th }}$ Council Meeting, Economic and Financial Committee, 11 July 2006, 11370/06 (Press 209). Brussels: DG G1, 2006.

Council of the EU. Press Release, $2753^{\text {th }}$ Council Meeting, Economic and Financial Committee, 10 October 2006, 13600/06 (Press 278). Luxembourg, 2006.

Council of the EU. Press Release, 2822 $2^{\text {th }}$ Council Meeting, Economic and Financial Committee, 09 October 2007, 13571/07 (Press 217). Luxembourg, 2007.

Council of the EU. Press Release, 2919 $9^{\text {th }}$ Council Meeting, Economic and Financial Committee, 20 January 2009, 5196/09 (Press 9). Brussels, 2009.

Council of the EU. Council Decision of 6 April 2009 on the Existence of an Excessive Deficit in France, 7897/09. Brussels: DG G1, 2009.

Council of the EU. Code of Conduct. Endorsed by the Ecofin Council on 10 November 2009.

Cowles, Maria Green. "Non-State Actors and False Dichotomies: Reviewing IR/IPE Approaches to European Integration." In The Political Economy of European Integration: Theory and Analysis, edited by Erik Jones and Amy Verdun, 25-38. New York: Routledge, 2005.

Cox, Robert W. Production, Power, and World Order: Social Forces in the Making of History. New York: Columbia University Press, 1987.

Crowley, Patrick. "The Shape of Things to Come: The EU's Post-EMU Institutional Architecture." In The Euro: European Integration Theory and Economic and Monetary Union, edited by Amy Verdun, 165-78. Lanham, Md.: Rowman \& Littlefield Publishers, 2002.

Curristine, Teresa. "Performance Information in the Budget Process: Results of the OECD 2005 Questionnaire.” OECD Journal on Budgeting 5, no. 2 (2005): 87-131. 
Daly, Glyn. "The Political Economy of (Im)Possibility." In International Political Economy and Poststructural Politics, edited by Marieke de Goede, 177-94. New York: Palgrave Macmillan, 2006.

Dean, Mitchell. "Putting the Technological Into Government." History of the Human Science 9, no.3 (1996): 47-68.

Dean, Mitchell. Governmentality: Power and Rule in Modern Society. New York: Sage, 1999.

Dean, Mitchell. Governing Societies: Political Perspectives on Domestic and International Rule. New York: Open University Press, 2007.

de Goede, Marieke. "Repoliticizing Financial Risk." Economy and Society 33, no. 2 (November 2004): 197-217.

de Goede, Marieke. Virtue, Fortune, and Faith: A Genealogy of Finance. Minneapolis: University of Minnesota Press, 2005.

de Goede, Marieke. "Discourse, Materiality and Economy." In International Political Economy and Poststructural Politics, edited by Marieke de Goede, 115-17. New York: Palgrave Macmillan, 2006.

de Goede, Marieke. "Introduction: International Political Economy and the Promises of Poststructuralism." In International Political Economy and Poststructural Politics, edited by Marieke de Goede, 1-20. New York: Palgrave Macmillan, 2006.

de Grauwe, Paul. Economics of Monetary Union. New York: Oxford University Press, 2007.

de Haan, Jakob et al, "Why the Stability and Growth Pact Failed?" International Finance 7, no. 2 (2004): 235-60.

Deleuze, Gilles. Negotiations, trans. by Martin Joughin. New York: Columbia University Press, 1995.

Deleuze, Gilles and Felix Guattari. A Thousand Plateaus: Capitalism and Schizophrenia II. Minneapolis: University of Minnesota Press, 1987.

Denzau, Arthur T. and Douglass C. North. "Shared Mental Models: Ideologies and Institutions." Kyklos 47, no. 1 (1994): 3-31.

Derrida, Jacques. Specters of Marx: The State of the Debt, the Work of Mourning, and the New International. New York: Routledge, 1994. 
Deuchars, Robert. The International Political Economy of Risk: Rationalism, Calculation and Power. Burlington: Ashgate Publishing Company, 2004.

Dixit, Avanish and Luisa Lambertini. "Symbiosis of Monetary and Fiscal Policies in a Monetary Union." Journal of International Economics 6 (2003): 235-47.

Donnelly, Shawn. “Explaining EMU Reform.” Journal of Common Market Studies 43, no. 5 (2005): 947-68.

Dyson, Kenneth. "The Evolving Timescapes of European Economic Governance: Contesting and Using Time." Journal of European Public Policy 16, no. 2 (2009): 286-306.

Dyson, Kenneth. The Politics of the Euro-Zone. New York: Oxford University Press, 2000.

Dyson, Kenneth. "EMU as Europeanisation: Convergence, Diversity and Contingency." In The Euro: European Integration Theory and Economic and Monetary Union, edited by Amy Verdun, 91-108. Lanham, Md.: Rowman \& Littlefield Publishers, 2002.

Dyson, Kenneth. "The Euro-Zone in a Political and Historical Perspective." In Political Aspects of the Economic and Monetary Union, edited by Soren Dosenrode, 17-40. Aldershot: Ashgate, 2002.

Dyson, Kenneth. "European States and the Euro Area: Clustering and Covariance in Patterns of Change." In The Euro at 10: Europeanization, Power, and Convergence, edited by Kenneth Dyson, 378-413. New York: Oxford University Press, 2008.

Dyson, Kenneth. "Germany: A Crisis in Leadership in the Euro Area." In The Euro at 10: Europeanization, Power, and Convergence, edited by Kenneth Dyson, 132-64. New York: Oxford University Press, 2008.

Dyson, Kenneth. "The First Decade." In The Euro at 10:Europeanization, Power, and Convergence, edited by Kenneth Dyson, 1-36. New York: Oxford University Press, 2008.

Dyson, Kenneth and Kevin Featherstone. The Road to Maastricht. Oxford: Oxford University Press, 1999.

Economic Policy Committee. "Initiatives to Improve the Efficiency and Effectiveness of Public Spending: Modernising Public Administration.” REP/53684 rev. 2, 2008.

Eichengreen, Barry. "Europe, the Euro and the ECB: Monetary Success and Fiscal Failure." Journal of Policy Modeling 27 (2005): 427-39. 
Eichengreen, Barry and Charles Wyplosz. “Instability Pact?" European Economic Perspectives 48 (1998).

Eichengreen, Barry and Charles Wyplosz. "The Stability Pact: More Than a Minor Nuisance?" Economic Policy 26 (1998): 65-114.

Eijffinger, Sylvester. "On a Reformed Stability and Growth Pact.” Intereconomics (2005): $141-47$.

Ericson, Richard V. "Governing through Risk and Uncertainty." Economy and Society 34, no. 4 (2005): 659-72.

Ericson, Richard V. and Aaron Doyle. "Risk and Morality." In Risk and Morality, edited by Richard V. Ericson and Aaron Doyle, 1-10. Toronto: U of T Press, 2003.

Ericson, Richard V. and Aaron Doyle. Uncertain Business: Risk, Insurance, and the Limits of Knowledge. Toronto: U of T Press, 2004.

European Central Bank. "Monetary Policy." Available from http://www.ecb.int/mopo/ $\mathrm{html} /$ index.en.html.

European Central Bank. The Statistics Pocketbook, January 2009. Frankfurt: European Central Bank, 2009.

European Commission: DG for Economic and Financial Affairs. "Stability and Growth Pact: Country-Specific Procedures." Available from http://ec.europa.eu.

European Commission: DG for Economic and Financial Affairs. European Economy: Broad Economic Policy Guidelines (for the 2005-08 period). Brussels: DG EcFin, 2005.

European Commission. Proposal for a Council Regulation: Amending Regulation (EC) No 1466/97 on the Strengthening of the Surveillance of Budgetary Positions and the Surveillance and Coordination of Economic Policies, 20 April 2005, Com (2005).

European Commission: DG for Economic and Financial Affairs. European Economy: Public Finances in EMU 2006. Brussels: DG EcFin, 2006.

European Commission, Quarterly Report, 5, no. 4 (2006).

European Commission: DG for Economic and Financial Affairs. European Economy: Public Finances in EMU 2007. Brussels: DG EcFin, 2007.

European Commission. Communication from the Commission to the European Council- $A$ European Economic Recovery Plan. Report to the European Council, 16097/08, 2008. 
European Commission: DG for Economic and Financial Affairs. European Economy: Public Finances in EMU 2008. Brussels: DG EcFin, 2008.

European Commission. "Communication from the Commission to the European Parliament and the Council, Long-Term Sustainability of Public Finances for a Recovering Economy, COM (2009) 545/3, 2009.

European Commission: DG for Economic and Financial Affairs. Interim Forecasts. Brussels: DG EcFin, 2009. Available from http://ec.europa.eu/economy_finance/ pdf/2009/interimforecastjanuary/ el.html.

European Commission: DG for Economic and Financial Affairs. European Economy: Public Finances in EMU 2009. Brussels: DG EcFin, 2009.

European Commission: DG for Economic and Financial Affairs. European Economic Forecasts- Autumn 2009. Brussels: DG EcFin, 2009; Available from http://ec.europa.eu/economy_finance/publications/publication16055_en.pdf.

European Commission: DG for Economic and Financial Affairs. Press Release, Commission Excessive Deficit Procedure Steps: The Stability and Growth Pact as the Anchor for Fiscal Exit Strategies, 11 November 2009, IP/09/1694. Brussels: DG EcFin, 2009.

European Round Table of Industrialists. "ERT Milestones and Chairmen." ERT. Available from http://www.ert.be/ert milestones and its chairmen.aspx.

Eurostat. "General government deficit (-) and surplus (+); Percentage of GDP," (2009). Available from http://epp.eurostat.ec.europa.eu.

Eurostat. "Euro-zone government deficit at 2.7\% of GDP and public debt at 70.7\% of GDP," News Release STAT/04/117, 23 September 2004. Available from http://ec.europa.eu/eurostat.

Ewald, Francois. "Insurance and Risk." In The Foucault Effect, edited by Graham Burchell, Colin Gordon, and Peter Miller, 197-210. Chicago: Chicago University Press, 1991.

Feldmann, Horst. "The Implementation of the Stability and Growth Pact: Taking Stock of the First Four Years." Journal of European Integration 25, no. 4 (2003): 287-309

Ferre, Montserrat. "Should Fiscal Authorities Co-operate in a Monetary Union with Public Deficit Targets?" Journal of Common Market Studies 43, no.3 (2005): 539-50.

Financial Times, 8 February 2000.

Fitoussi, Jean-Paul and Jacques Le Cacheux. Report on the State of the European Union, Volume 2: Reforming the European Union. New York: Palgrave MacMillan, 2007. 
Flower, John. European Financial Reporting: Adapting to a Changing World. New York: Palgrave Macmillan, 2004.

Foucault, Michel. The Order of Things: An Archaeology of the Human Science. New York: Vintage, 1970.

Foucault, Michel. Discipline and Punish: the Birth of the Prison. New York: Vintage, 1979.

Foucault, Michel. “Two Lectures.” In Power/Knowledge : Selected Interviews and Other Writings, edited by Colin Gordon, 78-108. New York: Pantheon, 1980.

Foucault, Michel. "Nietzsche, Genealogy, History." In The Foucault Reader, edited by Paul Rainbow, 76-100. New York: Pantheon, 1984.

Foucault, Michel. "What is Enlightenment?" In The Foucault Reader, edited by Paul Rainbow, 32-50. New York: Pantheon, 1984.

Foucault, Michel. The History of Sexuality, Vol. 1. New York: Vintage, 1990.

Foucault, Michel. "Questions of Method.” In The Foucault Effect, edited by Graham Burchell, Colin Gordon, and Peter Miller, 73-86. Chicago: Chicago University Press, 1991.

Foucault, Michel. Security, Territory, Population: Lectures at the College de France, 1977-78, trans. Graham Burchell Basingstoke. New York: Palgrave Macmillan, 2007.

Garland, David. "The Rise of Risk." In Risk and Morality, edited by Richard V. Ericson and Aaron Doyle, 48-86. Toronto: U of T Press, 2003.

Gibson-Graham, J.K. The End of Capitalism (As We Knew It): A Feminist Critique of Political Economy. Oxford: Blackwell, 1996.

Gibson-Graham, J.K. A Postcapitalist Politics. Minneapolis University of Minnesota Press, 2006.

Giddens, Anthony. Modernity and Self-Identity: Self and Society in the Late Modern Age. Stanford: Stanford University Press, 1991.

Gill, Stephen. "European Governance and New Constitutionalism: Economic and Monetary Union and Alternatives to Disciplinary Neo-liberalism in Europe." New Political Economy 3, no. 1 (1998): 5-26.

Gilpin, Robert. The Political Economy of International Relations. Princeton: Princeton University Press, 1987. 
Goodhart, C.A.E. "Replacing the Stability and Growth Pact?" In Euroland and the World Economy: Global Player or Global Drag? edited by Jorg Bibow and Andrea Terzi, 135-53. New York: Palgrave MacMillan, 2007.

Gordon, Colin. "Governmental Rationality: An Introduction." In The Foucault Effect, edited by Graham Burchell, Colin Gordon, and Peter Miller, 1-52. Chicago: Chicago University Press, 1991.

Guala, Francesco. "How to Do Things with Experimental Economics." In Do Economists Make Markets? On the Performativity of Economics, edited by Donald MacKenzie, Fabian Muniesa, and Lucia Siu, 128-62. Princeton: Princeton University Press, 2007.

Haahr, Jens H. "Open Co-ordination as Advanced Liberal Government." Journal of European Public Policy 11, no. 2 (2004): 209-30.

Haas, Peter. "Introduction: Epistemic Communities and International Policy Coordination." International Organization 46, no. 1 (1992): 1-35.

Hacking, Ian. "Making Up People." In Reconstructing Individualism: Autonomy, Individuality and the Self In Western Thought, edited by Thomas C. Heller, Morton Sosna, and David E. Wellbery, (Stanford, CA: Stanford University Press, 1986), 232-36.

Hacking, Ian. The Taming of Chance. New York: Cambridge University Press, 1990.

Hallerberg, Mark and Joshua Bridwell. "Fiscal Policy Coordination and Discipline: The Stability and Growth Pact and Domestic Fiscal Regimes." In The Euro at 10:Europeanization, Power, and Convergence, edited by Kenneth Dyson, 69-86. New York: Oxford University Press, 2008.

Hardt, Michael and Antonio Negri. Empire. Cambridge: Harvard University Press, 2000.

Harvey, David. The Limits of Capital. Oxford: Blackwell, 1982.

Hay, Colin. "Crisis and the Structural Transformation of the State: Interrogating Processes of Change." British Journal of Politics and International Relations 1, no. 3 (1999): $317-44$.

Hay, Colin. "The Genealogy of Neoliberalism." In Neoliberalism: National and Regional Experiments with Global Ideas, edited by Ravi K. Roy, Arthur T. Denzau, and Thomas D. Willet, 51-70. New York: Routledge, 2007. 
Hein, Eckhard and Achim Truger. "Fiscal Policy and Macroeconomic Performance in the Euro Area: Lesson for the Future." In Euroland and the World Economy: Global Player or Global Drag? edited by Jorg Bibow and Andrea Terzi, 154-83. New York: Palgrave MacMillan, 2007.

Heipertz, Martin and Amy Verdun. "The Dog that Would Never Bite? What We Can Learn from the Origins of the Stability and Growth Pact." Journal of European Public Policy 11, no. 5 (2004): 765-80.

Heipertz, Martin and Amy Verdun. "The Stability and Growth Pact Theorizing a Case in European Integration." Journal of Common Market Studies 43, no. 5 (2005): 9851008.

Heipertz, Martin and Amy Verdun. "The Dog that Would Never Bite? Origins, Crisis and Reform of Europe's Stability and Growth Pact." In EMU Rules: The Political and Economic Consequences of European Monetary Integration, edited Francisco Torres, Amy Verdun, and Hubert Zimmermann, 115-135. Baden-Baden: Nomos, 2006.

Hindess, Barry. "Investigating International Anti-corruption." Third World Quarterly 26, no. 8 (2005): 1389-398.

Hodson, Dermot. "Macroeconomic Co-ordination in the Euro Area: The Scope and Limits of the Open Method." Journal of European Public Policy 11, no. 2 (2004): 231-48.

Hodson, Dermot and Imelda Maher. "Soft Law and Sanctions: Economic Policy Co-ordination and Reform of the Stability and Growth Pact." Journal of European Public Policy 11, no. 5 (2004): 798-813.

Holmes, Douglas R. and George E. Marcus. "Cultures of Expertise and the Management of Globalization.” In Global Assemblages: Technology, Politics, and Ethics as Anthropological Problems, edited by Aihwa Ong and Stephen J. Collier, 235-252. Malden, MA: Blackwell Publishing, 2005.

Howarth, David. "EMU, Integration Theories, and the Annoying Complexities of French Policy-Making." In The Euro: European Integration Theory and Economic and Monetary Union, edited by Amy Verdun, 179-99. Lanham, Md.: Rowman \& Littlefield Publishers, 2002.

Hughes-Hallett, Andrew. "Sustainable Fiscal Policies and Budgetary Risk under Alternative Monetary Policy Arrangements." Economic Change and Restructuring 41, no. 1 (2008): 1-28.

Hutter, Bridget and Michael Power, Organizational Encounters with Risk. Cambridge: CUP, 2005. 
Huysmans, Jef. The Politics of Insecurity: Fear, Migration and Asylum in the EU. New York: Routledge, 2006.

Issing, Otmar. "The Stability and Growth Pact: The Appropriate Fiscal Framework for EMU." International Economics and Economic Policy 1 (2004): 9-13.

Issing, Otmar. The Birth of the Euro. New York: Cambridge University Press, 2008.

Jachtenfuchs, Markus et al. "Which Europe? Conflicting Models of the Legitimate European Political Order." European Journal of International Relations 4 (1999): $409-45$.

Jarvis, Darryl S.L. and Martin Griffiths. "Risk and International Relations: A New Research Agenda?" Global Society 21, no. 1 (2007): 1-4.

Jarvis, Darryl S.L. and Martin Griffiths. "Learning to Fly: The Evolution of Political Risk Analysis." Global Society 21, no. 1 (2007): 5-21.

Jensen, Ole B. and Tim Richardson. Making European Space: Mobility, Power and Territorial Identity. London: Routledge, 2003.

Jenson, Jane and Philippe Pochet. "Employment and Social Policy since Maastricht: Standing Up to European Monetary Union." In The Year of the Euro, edited by Robert M. Fishman and Anthony M. Messina, 161-85. Notre Dame, ID: Notre Dame University Press, 2006.

Jessop, Bob. The Future of the Capitalist State. Cambridge: Polity Press, 2002.

Jessop, Bob. State Power: A Strategic-Relational Approach. Malden, MA: Polity Press, 2008.

Jessop, Bob and Ngai-Ling Sum. "Pre-Disciplinary and Post-Disciplinary Perspectives." New Political Economy 6, no. 1 (2001): 89-102.

Jessop, Bob and Ngai-Ling Sum. "Towards a Cultural International Political Economy: Poststructuralism and the Italian School." In International Political Economy and Poststructural Politics, edited by Marieke de Goede, 157-76. New York: Palgrave Macmillan, 2006.

Jordan, Andrew and Adriaan Schout. The Coordination of the European Union: Exploring the Capacities of Networked Governance. New York: Oxford University Press, 2006. 
Kassim, Hussein and Anand Menon. "The Principal-Agent Approach and the Study of the European Union: Promise Unfulfilled?" In The Political Economy of European Integration: Theory and Analysis, edited by Erik Jones and Amy Verdun, 39-53. New York: Routledge, 2005.

Keynes, John Maynard. Treatise on Probability. London: MacMillan, 1921, AMS Press Reprint, 1979.

Keynes, John Maynard. "Theory of Employment." Quarterly Journal of Economics 51, no. 2 (1937): 209-32.

King, Roger. The Regulatory State in an Age of Governance. New York: Palgrave Macmillan, 2007.

Knight, Frank. Risk, Uncertainty and Profit. New York: A.M. Kelley, 1921/1964.

Kopits, George. "Fiscal Rules: Useful Policy Framework of Unnecessary Ornament?" Banca d'Italia (2001): 59-84.

Kuritzkes, Andrew. "Operational Risk Capital: A Problem of Definition." The Journal of Risk Finance 4, no. 1 (2002): 47-56.

Kuritzkes, Andrew and Hal S. Scott. "Sizing Operational Risk and the Effect of Insurance: Implications of the Basel II Capital Accord." In Capital Adequacy beyond Basel: Banking, Securities, and Insurance, edited by Hal S. Scott, 258-83. New York: Oxford University Press, 2005.

Laclau, Ernesto and Chantal Mouffe. Hegemony and Socialist Strategy: Towards a Radical Democratic Politics. London: Verso, 1985.

Laffey, Mark. "Locating Identity: Performativity, Foreign Policy and State Action." Review of International Studies 26, no. 3 (2000): 429-44.

Larner, Wendy and Richard Le Heron. "Global Benchmarking: Participating 'At a Distance' in the Globalizing Economy." In Global Governmentality: Governing International Spaces, edited by Wendy Larner and William Walters, 212-32. London: Routledge, 2004.

Lash, Scott. "Reflexive Modernization: The Aesthetics Dimension." Theory, Culture and Society 10 (1993): 1-23.

Latour, Bruno. Science in Action. Milton Keynes: Open University Press, 1987.

Latour, Bruno. We Have Never Been Modern. Hemel Hempstead: Harvester Wheatsheaf, 1993. 
Lazzarato, Maurizio. "Life and the Living in the Societies of Control." In Deleuze and the Social, edited by Martin Fuglsang and Bent Meier Sorensen, 171-90. Edinburgh: Edinburgh University Press, 2006.

Leblang, David. "To Devalue or to Defend? The Political Economy of Exchange Rate Policy." International Studies Quarterly 47 (2003): 533-60.

Leblond, Patrick. "The Political Stability and Growth Pact is Dead: Long Live the Economic Stability and Growth Pact." Journal of Common Market Studies 44, no. 5 (2006): 969-90.

Leicht, Kevin T. and J. Craig Jenkins. "Political Resources and Direct State Intervention: The Adoption of Public Venture Capital Programs in the American States, 19741990." Social Forces 76, no. 4 (1998): 1323-45.

Lepinay, Vincent-Antonin. "Decoding Finance: Articulation and Liquidity Around a Trading Room." In Do Economists Make Markets? On the Performativity of Economics, edited by Donald MacKenzie, Fabian Muniesa, and Lucia Siu, 87-127. Princeton: Princeton University Press, 2007.

Lipietz, Alain. Mirages and Miracles: The Crisis of Global Fordism. London: Verso, 1987.

Lipschutz, Ronnie D. and James Rowe. Globalization, Governmentality and Global Politics: Regulation for the Rest of Us? New York: Routledge, 2005.

Loedel, Peter H. "Multilevel Governance and the Independence of the ECB." In The Euro: European Integration Theory and Economic and Monetary Union, edited by Amy Verdun, 125-44. Lanham, Md.: Rowman \& Littlefield Publishers, 2002.

Lohmann, Susanne. "Sollbruchstelle: Deep Uncertainty and the Design of Monetary Institutions." International Finance 16, no. 1 (2000): 95-110.

Luhmann, Niklas. Risk: A Sociological Theory. Berlin: de Gruyter, 1993.

Luhmann, Niklas. Social Systems. Palo Alto: Stanford University Press, 1995.

Lyon, David. "The Search for Surveillance Theories." In Theorizing Surveillance, edited by David Lyon, 3-20. Portland: William Publishing, 2006.

Mabbett, Deborah and Waltraud Schelkle. "Bringing Macroeconomics Back into the Political Economy of Reform: the Lisbon Agenda and the 'Fiscal Philosophy' of EMU.” Journal of Common Market Studies 45, no. 1 (2007): 81-103.

Macartney, Huw and Michael Moran. "Banking and Financial Market Regulation and Supervision." In The Euro at 10:Europeanization, Power, and Convergence, edited by Kenneth Dyson, 325-40. New York: Oxford University Press, 2008. 
Macdonald, Kate. "Public Accountability within Transnational Supply Chains: A Global Agenda for Empowering Southern Workers?" In Global Accountabilities:

Participation, Pluralism, and Public Ethics, edited by Alnoor Ebrahim and Edward Weisband, 252-79. New York: Cambridge University Press, 2007.

MacKenzie, Donald. An Engine, Not a Camera. Cambridge, MT: The MIT Press, 2006.

MacLeod, Michael R. "Financial Actors and Instruments in the Construction of Global Corporate Social Responsibility." In Global Accountabilities: Participation, Pluralism, and Public Ethics, edited by Alnoor Ebrahim and Edward Weisband, 227-51. New York: Cambridge University Press, 2007.

Majone, Giandomenico. Regulating Europe. London: Routledge, 1996.

Malinvaud, Edmond. "First Order Certainty Equivalence.” Econometrica 37, no. 4 (1969): 706-18.

Marcussen, Martin. Ideas and Elites: The Social Construction of Economic and Monetary Union. Aalborg: Aalborg University Press, 2000.

Marcussen, Martin. "The Basel Committee as a Transnational Governance Network." In Democratic Network Governance in Europe, edited by Martin Marcussen and Jacob Torfing, 214-31. New York: Palgrave Macmillan, 2007.

Marcussen, Martin. "The Lisbon Process and Economic Reform." In The Euro at 10: Europeanization, Power, and Convergence, edited by Kenneth Dyson, 87-107. New York: Oxford University Press, 2008.

Marcussen, Martin and Jacob Torfing, ed. Democratic Network Governance in Europe. New York: Palgrave Macmillan, 2007.

McNamara, Kathleen. The Currency of Ideas: Monetary Politics in the European Union. Ithaca, N.Y.: Cornell University Press, 1998.

McNamara, Kathleen. "Economic Governance, Ideas and EMU: What Currency Does Policy Consensus Have Today?" Journal of Common Market Studies 44, no. 4 (2006): 803-21.

Miles, Lee. "Euro-Outsiders and the Politics of Asymmetry." European Integration 27, no. 1 (2005): 3-23.

Miller, Peter. “Governing by Numbers: Why Calculative Practices Matter.” Social Research 68, no. 2 (2001): 389-96.

Miller, Peter and Nikolas Rose, ed. The Power of Psychiatry. Cambridge: Polity Press, 1986. 
Miller, Peter and Nikolas Rose. "Governing Economic Life.” Economy and Society 19, no. 1 (1990): 1-31.

Mitchell, Timothy. Rules of Experts: Egypt, Techno-Politics, Modernity. Berkeley: University of California Press, 2002.

Mitchell, Timothy. "The Properties of Markets." In Do Economists Make Markets? On the Performativity of Economics, edited by Donald MacKenzie, Fabian Muniesa, and Lucia Siu, 244-75. Princeton: Princeton University Press, 2007.

Moravcsik, Andrew. "Taking Preferences Seriously: A Liberal Theory of International Politics.” International Organization 51, no.4 (1997): 513-53.

Moravcsik, Andrew. The Choice for Europe: Social Purpose and State Power from Messina to Maastricht. Ithaca: Cornell University Press, 1998.

Moravcsik, Andrew. "A New Statecraft? Supranational Entrepreneurs and International Cooperation." International Organization 53, no. 2 (1999): 267-306.

Nietzsche, Friedrich. The Genealogy of Morals. New York: Oxford University Press, 1996.

O’Malley, Pat. "Risk and Responsibility." In Foucault and Political Reason: Liberalism, Neo-liberalism and Rationalities of Government, edited by Andrew Barry, Thomas Osborne, and Nikolas Rose, 189-207. Chicago: The University of Chicago Press, 1996.

O’Malley, Pat. "Moral Uncertainties: Contract Law and Distinctions between Speculation, Gambling, and Insurance." In Risk and Morality, edited by Richard V. Ericson and Aaron Doyle, 231-57. Toronto: U of T Press, 2003.

O’Malley, Pat. Risk, Uncertainty and Government. Portland: The Glasshouse Press, 2004.

Ong, Aihwa and Stephen J. Collier, ed. Global Assemblages: Technology, Politics, and Ethics as Anthropological Problems. Malden, MA: Blackwell Publishing, 2005.

Papademos, Lucas. "The Political Economy of the Reformed Stability and Growth Pact: Implications for Fiscal and Monetary Policy." Speech given at the Conference "The ECB and Its Watchers VII." Frankfurt, Germany, June 3, 2005.

Panjer, Harry H. Operational Risks: Modeling Analytics. Hoboken, NJ: John Wiley \& Sons, 2006.

Parker, George. "Germany and ECB Argue over Pact's Collapse." Financial Times, 1 December, 2003. 
Peterson, V. Spike. "Getting Real: The Necessity of Critical Poststructuralism in Global Political Economy." In International Political Economy and Poststructural Politics, edited by Marieke de Goede, 119-38. New York: Palgrave Macmillan, 2006.

Pistor, Marcus. "Agency, Structure and European Integration: Critical Political Economy and the New Regionalism in Europe." In The Political Economy of European Integration: Theory and Analysis, edited by Erik Jones and Amy Verdun, 108-127. New York: Routledge, 2005.

Pollack, Mark. "A Blairite Treaty: Neoliberalism and Regulated Capitalism in the Treaty of Amsterdam." In European Integration after Amsterdam: Institutional Dynamics and Prospects for Democracy, edited by Karl-Heinz Neunreither and Antje Weiner, 266-89. Oxford: Oxford University Press, 1999.

Poulantzas, Nicos. State, Power, Socialism. London: Verso, 1978.

Power, Michael. The Audit Society: Rituals of Verification. New York: OUP, 1999.

Power, Michael. The Risk Management of Everything. London: Demos, 2004.

Power, Michael. Organized Uncertainty: Designing a World of Risk Management. New York: Oxford University Press, 2007.

Pryke, Michael and John Allen. "Monetized Time-Space: Derivative-Money's 'New Imaginary."' Economy and Society 29, no. 2 (May 2000): 264-84.

Puetter, Uwe. "Governing Informally: The Role of the Eurogroup in EMU and the Stability and Growth Pact." Journal of European Public Policy 11, no. 5 (2004): 854-70.

Puetter, Uwe. The Eurogroup. New York: Manchester University Press, 2006.

Puetter, Uwe. "Providing Venues for Contestation: The Role of Expert Committees and Informal Dialogue Among Ministers in European Economic Policy Coordination." Comparative European Politics 5, no. 1 (2007): 18-35.

Putnam, Robert. "Diplomacy and Domestic Politics: The Logic of Two-level Games." International Organization 42, no. 3 (1988): 427-60.

Rao, Hayagreeva. "The Social Construction of Reputation: Certification Contests, Legitimation, and the Survival of Organizations in the American Automobile Industry: 1895-1912." Strategic Management Journal 15 (1994): 29-44.

Rhodes, Martin. "'Varieties of Capitalism' and the Political Economy of European Welfare States." New Political Economy, 10, no. 3 (2005): 363-70. 
Risse, Thomas. "Social Constructivism and European Integration." In European Integration Theory, edited by Antje Wiener and Thomas Diez, 159-75. New York: Oxford University Press, 2004).

Risse, Thomas. "The Euro between National and European Identity." In The Year of the Euro, edited by Robert M. Fishman and Anthony M. Messina, 65-80. Notre Dame, ID: Notre Dame University Press, 2006.

Risse, Thomas et al. "To Euro or Not to Euro? The EMU and Identity Politics in the European Union." European Journal of International Relations 5, no. 2 (1999): 147-87.

Roden, Frederick. "Becoming Bulterian: On the Discursive Limits (and Potentials) of Gender Trouble at Ten Years of Age." International Journal of Sexuality and Gender Studies 6 (2001): 25-33.

Rose, Nikolas. "Governing by Numbers: Figuring out Democracy." Accounting, Organizations and Society 16, no. 7 (1991): 673-92.

Rose, Nikolas. "Governing 'Advanced' Liberal Democracies." In Foucault and Political Reason: Liberalism, Neo-liberalism and Rationalities of Government, edited by Andrew Barry, Thomas Osborne, and Nikolas Rose, 37-64. Chicago: The University of Chicago Press, 1996.

Rose, Nikolas. Powers of Freedom. New York: Cambridge University Press, 1999.

Rose, Nikolas and Peter Miller. "Political Power beyond the State." British Journal of Sociology 43, no. 2 (1992): 173-205.

Rose, Nikolas and Peter Miller. Governing the Present: Administrating Economic, Social and Personal Life. Malden, MA: Polity Press, 2008.

Rose, Nikolas, Pat O'Malley, and Mariana Valverde. "Governmentality." Annual Review of Law Social Science 2, no. 5 (2006): 5.1-5.22.

Rosow, Stephen J. "Echoes of Commercial Society: Liberal Political Theory in Mainstream IPE.” In Constituting International Political Economy: International Political Economy Yearbook, Vol. 10, edited by Kurt Burch and Robert A. Denemark, 41-56. Boulder CO: Lynne Rienner, 1997.

Roy, Ravi K., Arthur T. Denzau, and Thomas D. Willet. "Introduction: Neoliberalism as a Shared Mental Model." In Neoliberalism: National and Regional Experiments with Global Ideas, edited by Ravi K. Roy, Arthur T. Denzau, and Thomas D. Willet, 313. New York: Routledge, 2007.

Ruggie, John G. "Territoriality and Beyond: Problematizing Modernity in International Relations." International Organization 47 (1993): 139-74 
Rumford, Chris. Cosmopolitan Spaces: Europe, Globalization, Theory. New York: Routledge, 2008.

Ryner, Magnus. "International Political Economy: Beyond the Poststructuralist/Historical Materialist Dichotomy." In International Political Economy and Poststructural Politics, edited by Marieke de Goede, 139-56. New York: Palgrave Macmillan, 2006.

Savage, James D. and Amy Verdun. "Reforming Europe's Stability and Growth Pact: Lessons from the American Experience in Macrobudgeting." Review of International Political Economy 14, no.5 (2007): 842-67.

Schelkle, Waltraud. "The Political Economy of Fiscal Policy Co-ordination in EMU: From Disciplinarian Device to Insurance Arrangement." Journal of Common Market Studies 43, no. 2 (2005): 371-91.

Schelkle, Waltraud. "Understanding New Forms of European Integration: A Study of Competing Political Economy Explanations." In The Political Economy of European Integration: Theory and Analysis, edited by Erik Jones and Amy Verdun, 149-69. New York: Routledge, 2005.

Schelkle, Waltraud. "The Theory and Practice of Economic Governance in EMU Revisited: What Have We Learned About Commitment and Credibility?" Journal of Common Market Studies 44, no. 4 (2006): 669-85.

Schelkle, Waltraud. "EU Fiscal Governance: Hard Law in the Shadow of Soft Law?" Columbia Journal of European Law 13 (2007): 705-31.

Schelkle, Waltraud. "The Contentious Creation of the Regulatory State in Fiscal Surveillance." West European Politics 32, no. 4 (2009): 829-46.

Schmidt, Vivien. Democracy in Europe: The EU and National Polities. New York: OUP, 2006.

Schuberth, Helene. "Knightian Uncertainty, Accountability and Economic Policy Rules." In Economic Policy under Uncertainty: The Role of Truth and Accountability in Policy Advice, edited by Peter Mooslechner, Helene Schuberth, and Martin Schürz, 261-89. Northampton: Edward Elgar, 2004).

Schure, Paul and Amy Verdun. "States and the Exercise of Power in the New European Union." In Political and Economic Consequences of Economic and Monetary Union: Taking Stock of the First Eight Years, edited by Amy Verdun, 57-78. New York: Nova Science Publishers, 2007. 
Schwarzer, Daniela. "Transnational Consensus Building in EMU Economic Governance." In Transnational European Union: Towards a Common Political Space, edited by Wolfram Kaiser and Peter Starie, 210-27. New York: Routledge, 2005.

Simmel, Georg. "The Metropolis and Mental Life," trans. Edward A. Shils. In Second-Year Course in the Study of Contemporary Society, edited by Harry D. Gideonse et al. Chicago: Chicago University Press, 1936.

Snyder, Francis. "The Effectiveness of European Community Law: Institutions, Processes, Tools and Techniques." In Implementing EC Law in the United Kingdom:

Structures for Indirect Rule, edited by Terence Daintith, 51-87. Chichester: Wiley, 1995.

Stiglitz, Joseph and Bruce Greenwald. Towards a New Paradigm in Monetary Economics. Cambridge: Cambridge University Press, 2003.

Subacchi, Paola. "Reforming Economic Governance in Europe: Exploring the Road to Effective Coordination." International Affairs 81, no. 4 (2005): 741-55.

Tabellini, Guido. "Money, Debt and Deficits in a Dynamic Game." Journal of Economic Dynamics and Control 10 (1986): 227-42.

The Economist, 29 September 2007.

Thrift, Nigel. "Movement-Space: The Changing Domain of Thinking Resulting from the Development of New Kinds of Spatial Awareness." Economy and Society 33, no. 4 (November 2004): 582-604.

Torfing, Jacob. "Discourse Theory: Achievements, Arguments, and Challenges." In

Discourse Theory in European Politics: Identity, Policy and Governance, edited by David Howarth and Jacob Torfing, 1-32. New York: Palgrave, 2005.

Trichet, Jean-Claude. Interview by Pierre-Antoine Delhommais and Arnaud Leparmentier. Le Monde. 17 November 2009.

Trichet, Jean-Claude. Interview by Cor de Horde and Klaas Broekhuizen. Het Financieele Dagblad, The Netherlands, 16 November 2009.

Umbach, Gaby and Wolfgang Wessels. "The Changing European Context of Economic and Monetary Union: 'Deepening', 'Widening', and Stability." In The Euro at 10: Europeanization, Power, and Convergence, edited by Kenneth Dyson, 54-68. New York: Oxford University Press, 2008.

van Apeldoorn, Bastiaan. Transnational Capitalism and the Struggle over European Integration. New York: Routledge, 2002. 
van Apeldoorn, Bastiaan. "Theorizing the Transnational: A Historical Materialist Approach." Journal of International Relations and Development 7, no. 2 (2004): 142-76.

van Apeldoorn, Bastiaan, Henk Overbeek, and Magnus Ryner. "Theories of European Integration: A Critique." In A Ruined Fortress? Neoliberal Hegemony and Transformation in Europe, edited by Alan W. Cafruny and Magnus Ryner, 17-46. Lanham, Md.: Rowan \& Littlefield, 2003.

van der Pijl, Kees. Transnational Relations and International Relations. New York: Routledge, 1998.

van der Pijl, Kees. “A Lockean Europe.” New Left Review 37 (2006): 9-38.

Van Loon, Joost. Risk and Technological Culture: Towards a Sociology of Virulence. New York: Routledge: 2002.

Verdun, Amy, ed. The Euro: European Integration Theory and Economic and Monetary Union. Lanham, Md.: Rowman \& Littlefield Publishers, 2002.

Walker, R.B.J. Inside/Outside: International Relations as Political Theory. New York: Cambridge University Press, 1993.

Walters, William. "Decentring the Economy." Economy and Society 28, no. 2 (1999): $312-$ 23.

Walters, William. "Mapping Schengenland: Denaturalizing the Border." Environment \& Planning D: Society \& Space 20, no. 5 (2002): 561-80.

Walters, William. "Rethinking Borders beyond the State." Comparative European Politics 4 (2006): 141-59.

Walters, William and Jens Henrik Haahr. Governing Europe: Discourse, Governmentality and European Integration. New York: Routledge, 2005.

Weir, Lorna. "Recent Developments in the Government of Pregnancy." Economy and Society 25, no. 3 (1996): 372-92.

Wendt, Alexander. "The Agent-Structure Problem in International Relations." International Organization 41, no. 3 (1987): 335-70.

Wendt, Alexander. Social Theory of International Politics. Cambridge: CUP, 1999.

Wendt, Alexander and Daniel Friedheim. "Hierarchy under Anarchy: Informal Empire and the East German State." International Organization 49, no. 4 (1995): 689-721. 
Wessels, Wolfgang. “An Ever Closer Fusion? A Dynamic Macro-political View on Integration Process." Journal of Common Market Studies 35, no. 3 (1997): 267-99.

Wessels, Wolfgang and Thomas Traguth. "Opportunity or Overstretch? The Unexpected Dynamics of Deepening and Widening." In Crises in European Integration. Challenges and Responses, 1945-2005, edited by Ludger Kühnhardt, 79-94. Oxford: Berghahn Books, 2008.

Wight, Colin. Agents, Structures and International Relations. New York: Cambridge University Press, 2006.

Winkler, Bernard. "Stability and Growth: The Role of Monetary Policy and Other Policy Actors in EMU." In EMU Rules: The Political and Economic Consequences of European Monetary Integration, edited Francisco Torres, Amy Verdun, and Hubert Zimmermann, 161-178. Baden-Baden: Nomos, 2006.

Wolf, Eric R. Europe and the People without History. Berkeley: University of California Press, 1982.

World Bank. Strengthening Bank Group Engagement in Governance and Anticorruption. Strategic Paper. Washington, D.C., 2007.

World Bank. "Guiding Principles for Strengthening World Bank Group Engagement on Governance and Anticorruption." Available from http://web.worldbank.org.

World Bank. Governance and Anti-Corruption (GAC): Implementation in MNA. Fast Brief 22. Washington, D.C., 2009.

Zinn, Jens O. and Peter Taylor-Gooby. "Risk as an Interdisciplinary Research Area." In Risk in Social Science, edited by Peter Taylor-Gooby and Jens Zinn, 20-51. New York: Oxford University Press, 2006. 